Historic, Archive Document

Do not assume content reflects current scientific knowledge, policies, or practices. 



\section{$6273 \quad$ JAN291914}

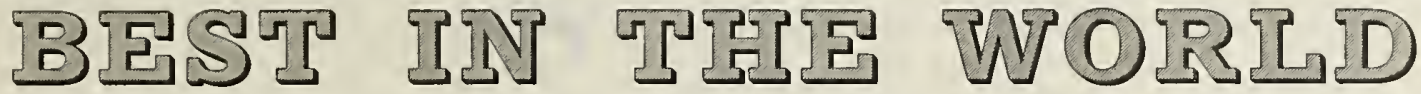

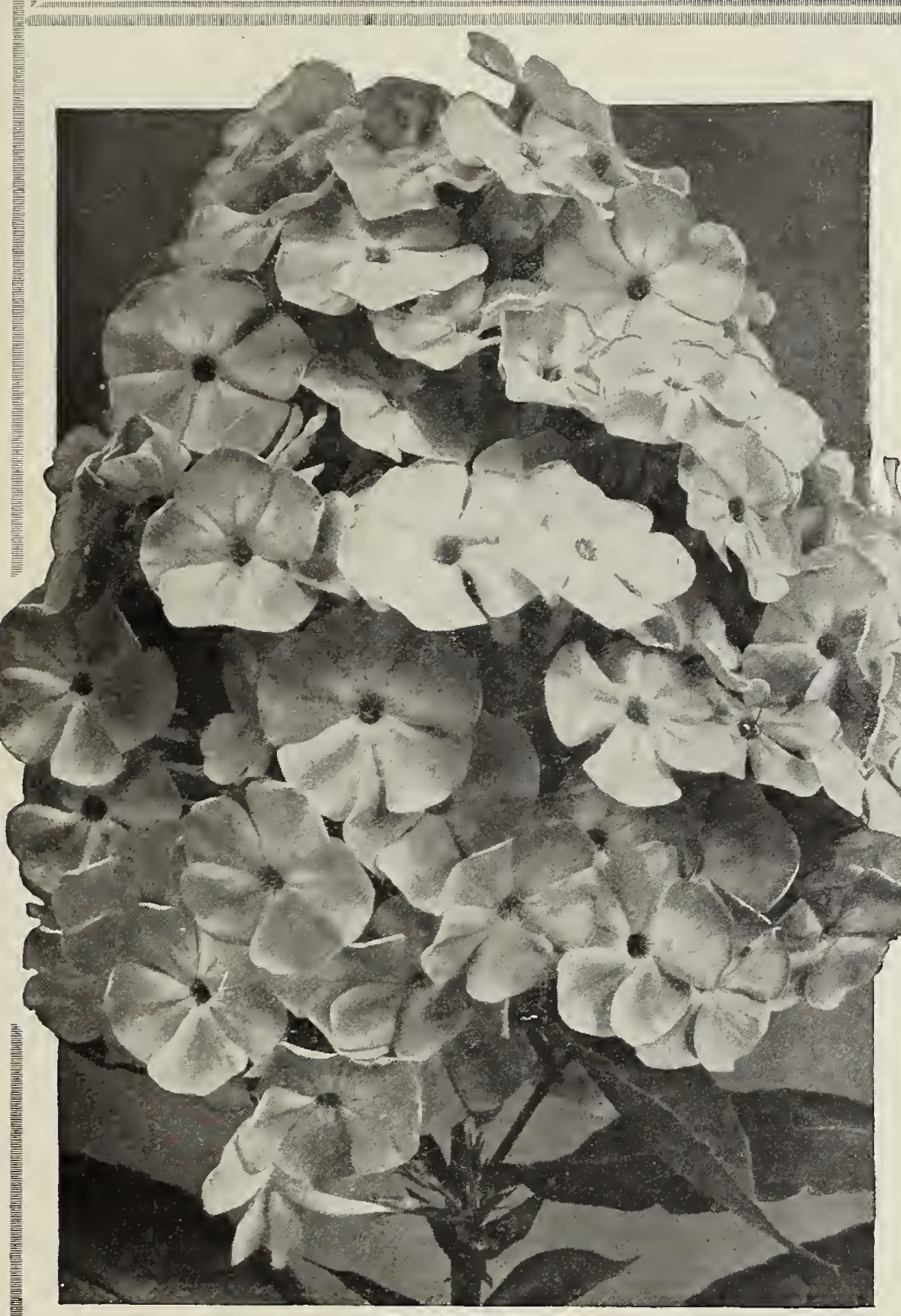

HIS Nursery offers the
largest and best collec-
tion of Trees, Shrubs
and Plants in the world.
The largest, because it offers the products of the leading nurseries of America, Europe and Japan; the best, because, in addition to its specialties which it grows, expert knowledge is used in selecting stock in the best nurseries. This business, established 2 I years, has given such satisfaction that there are but few nurserymen and plantsmen who handle so great a variety or quantity of stock.

Our business is a unique one. As growers, we grow only specialties, and endeavor to grow these better than they can be obtained elsewhere. When anything eIse is ordered, we buy it direct from the very best grower of that particular tree, shrub or plant, wherever he may be found, in America, Europe or Japan. By combining the orders of a great many, we obtain very low prices, and give our customers the benefrt by charging only a moderate profit for our services.

In connection with our offrce, we have extensive Experimental Grounds, in which aII novelties, rarities and standard varieties are tested. To avoid misunderstandings, customers are requested to read the terms on second page before ordering.

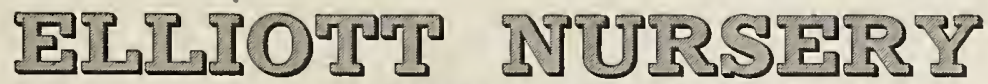

NURSERTMIEN

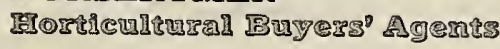

\section{J. WULEINSOIS FLITONIS}

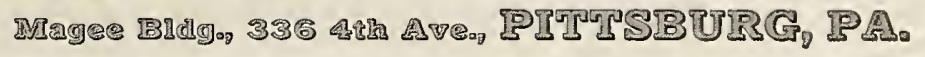




\section{Terms of Payment}

Our terms of payment are invariably cash on delivery; which does not mcan that we ship C. O. D., as we will not do so under any cireumstances. We deliver the goods and mail bills at the same time, and expect payment within a few days. People unknown to us will please send references with their order.

\section{NO AGENTS EMPLOYED}

It has been reported to us that swindlers have represented themselves as our agents in various parts of the country. We employ no agents whatevcr, but do an EXCLUSIVELY RETAIL BUSINESS DIRECT WITH OUR CUSTOMERS.

\section{PRICES}

Prices in this list are made subject to stock offered being unsold when ordered.

\section{GUARANTEES}

Wc guarantee all nursery stock furnished by us to be first-class, true to name, and delivered in gool eondition when shipped by express, and will replace free any stock spoiled in transit. STOCK SHIPPED BY FREIGHT IS AT THE PURCHASER'S RISK.

WE DO NOT GUARANTEE STOCK TO GROW, OR RESULTS IN ANY WAY. NO COMPLAINT WILL BE ENTERTAINED THAT IS NOT MADE IMMEDIATELY UPON RECEIPT OF STOCK.

There are so many causes for failure over which we have no control that we can assume no responsibility after stock is delivered in good order. Poor soil, unfavorable weather, ignorant or careless culture-all contribute to failure and all are beyond our control.

A Catalogue as comprehensive as this must of necessity offer some varieties of difficult culture, and, when these are ordered, we presume the people ordering them have the knowledge needed for their culture. Successful gardening requires knowledge, enthusiasm and perseverance, and these wc eannot supply, but we shall be glad to make selections of thc "can't-be-killed" class of plants for people who wish them.

\section{PARCEL POST}

There is a general impression that Pareel-Post ratcs of postage apply to nurscry stock. This is not so. The postage rate on shrubs, plants, bulbs and seeds is one cent for two ounces, regardless of the distance, and, except for very small packages or very long distances, cxpress rates are cheaper.

\section{SHIPPING DIRECTIONS}

Please give explicit shipping directions, stating whether stock is to be shipped by freight or express, and by what routc. Early orders for trees, shrubs and bulbs can be generally shipped safely by freight, but shipments will be sent by freight at the risk of the purchaser only.

Our express shipments are made by Adams or Wells-Fargo Express Companies. We cannot ship direct by any other companies. 


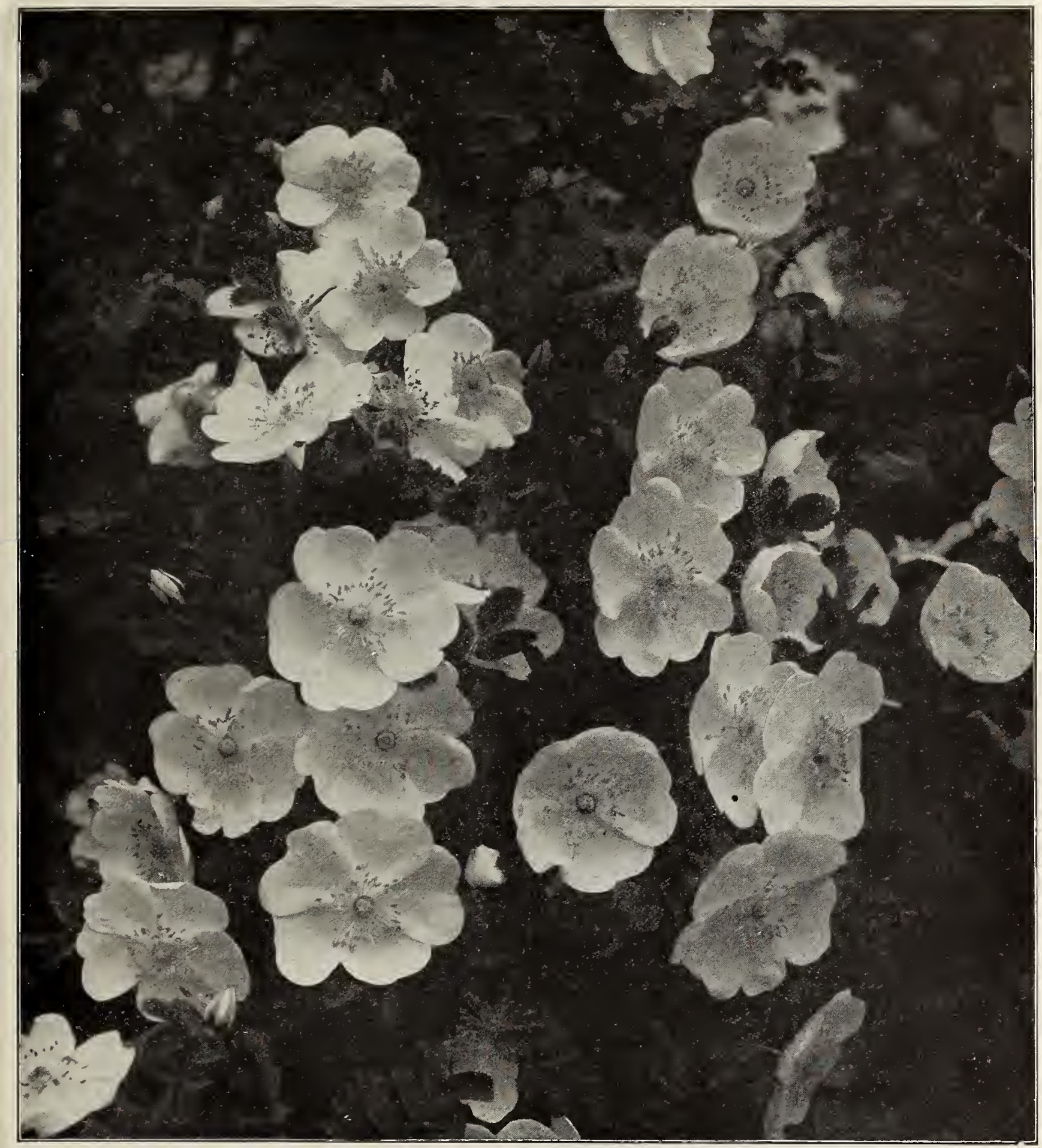

\section{Rosa spinosissima}

We have again succeeded in getting a stock of this rare and exquisitely beautiful single hardy Rose. In our opinion it is one of the most beautiful things on earth, and is surpassed only by the Cherokee Rose of the South, which is not hardy in our climate. This Rose grows to 4 or 5 feet; compact and bushy in habit, and in June is covered with large, single, yellowish white flowers of indescribable beauty. Planted in groups in the shrubbery, it produces an effect to which no description can do justice. Extra-strong plants, 50 cts. each, $\$ 5$ per doz.; good plants, 30 cts. each, $\$ 3$ per doz., $\$ 20$ per 100.

Rosa spinosissima hybrida. This charming hybrid of the above produced in our nursery. Beautiful, single, white flowers, delicately tinted pink; charming. 30 cts. each, $\$ 3$ per doz., $\$ 20$ per 100 . 


\section{NOVELTIES AND SPEGIALTIES}

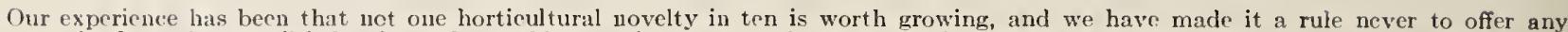

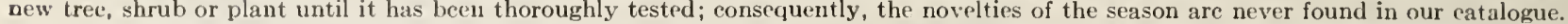

\section{Artemisia lactiflora}

One of the best introductions of recent years. It is a plant of noble appearance, 6 to 8 feet high, having beautifully formed, dark green leaves, and bearing feathery spikes, 3 to 4 feet long, of the purest white, sweetly fragrant, and flowering in late autumn. 25 ets. each, $\$ 2.50$ per doz.

\section{Anchusa Italica, Lissadell Variety}

In every point an improvement of the now well-known Dropmore varicty. The habit is more rolts st, the color of the large flowers, neasuring $11 / 2$ inches across, still mole brilkiant. A great acquisition. 30 ets. each, $\$ 3$ per doz.

\section{Gypsophila}

Scorzoneræfolia. Beautiful rose-colored Baby's Breath. It grows $110 \mathrm{nl} 3$ to 4 feet high and bear's the whole summer through a mass of deep rose-colored flowers, while the leaves are glaucous. A distinet novelty and extremely rare. $25 \mathrm{cts}$. each, $\$ 2.50$ per doz.

\section{Veronica elegantissima formosa}

Charming dwarf plant, forming a dense mat an inch high, eovered in spring with small white flowers, veined with blue. 20 cts. each, $\$ 2$ per doz.

\section{Hydrangea}

Standard. Of the well-known hardy Hydrangea we have secured some fine standards. 50 cts. each.

Arborescens grandiflora. This is a splendid improvement on our native Hydrangea. It has large panicles of pure white flowers ranging from 6 to 10 inches across, and is in bloom from July until frost; is undoubtedly one of the most valuable shrubs introducer for many years. It will thrive in either sun or shade. $30 \mathrm{cts}$. each $\$ 3$ per doz.; extra-large, bushy plants, 50 cts. each, $\$ 5$ per doz.

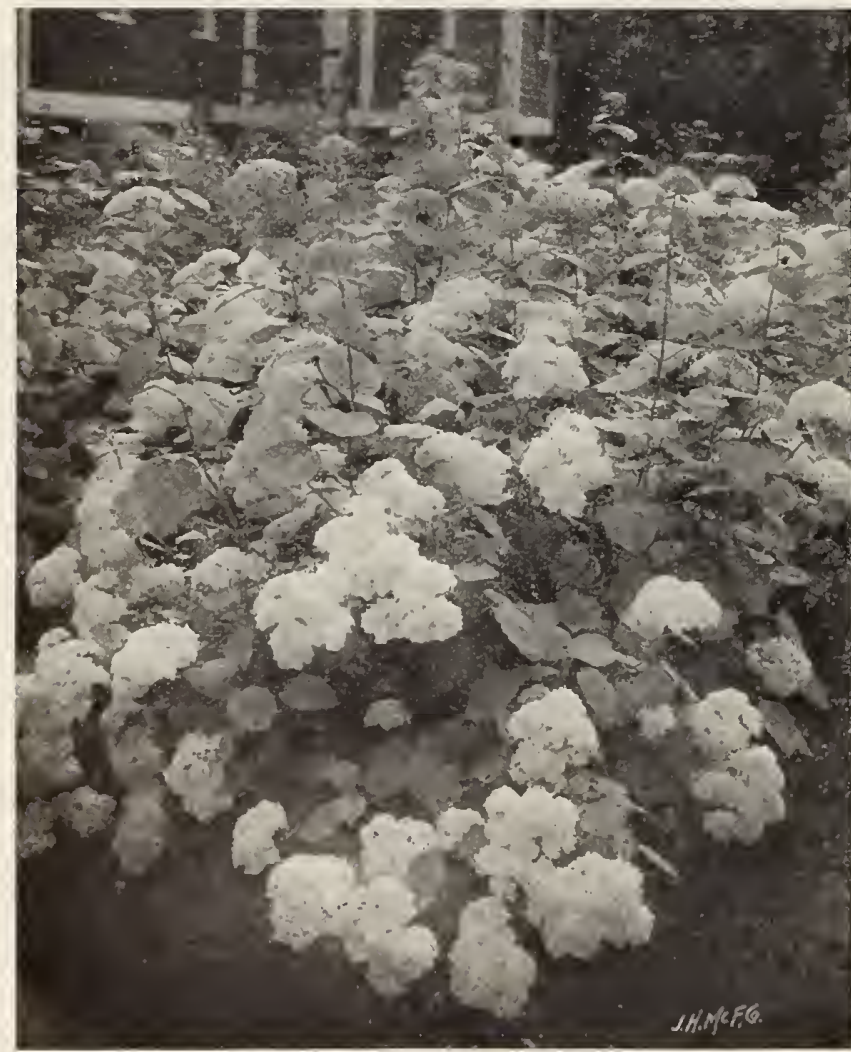

Hydrangea arborescens grandiflora

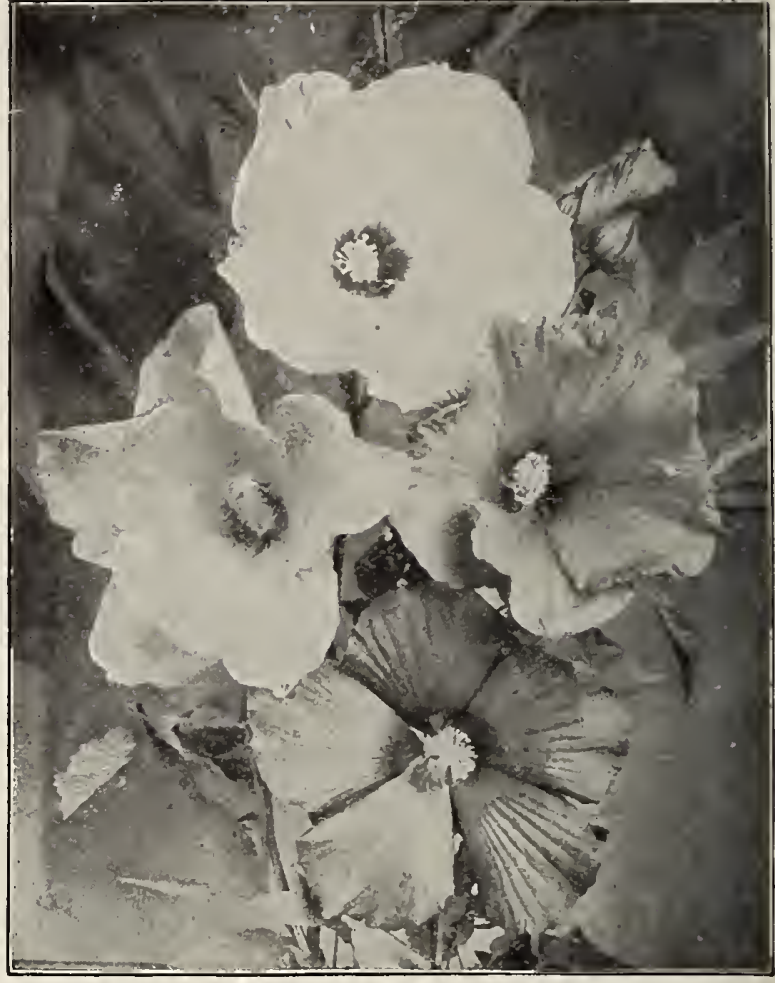

“Meehan's Mallow Marvels"

\section{"Meehan's Mallow Marvels"}

We have thoroughly tested this new Hibiscus and have found it very beautiful and desirable in every respect. It is a hybrid of the well-known Hibiscus Moscheutos and the tropical Hibiscus so largely grown in Florida, and combines the hardiness of the former with the brilliant colors of the latter. It makes a large bush and produces its immense, brilliant flowers freely from July until frost. The white-flowered varieties are very nearly like the white variety of Hibiscus Moscheutos. In separate colors, 2-year-old plants, Red, Crimson, Pink and White. 60 cts. each, $\$ 6$ per doz. Mixed colors without labels, 20 cts. each, $\$ 2$ per doz.

\section{Calimeris incisa}

An attractive plant for the border: grows 12 to 18 inches high producing from July to September daisy-like, bluish white flowers with yellow centers. 15 cts. each, $\$ 1.50$ per doz.

\section{Campanula rotundifolia Hostii}

A beautiful variety of "Blue Bells of Scotland." Delight ful blue flowers, borne on slender stems, nodding and swaying in the passing breeze. 15 ets. each, $\$ 1.50$ per doz.

\section{Arenaria montana}

Beautiful, dwarf, white-flowering plant which will thrive in a dry situation. $20 \mathrm{cts}$. each, $\$ 2$ per doz.

\section{Trollius. Globe Flower}

Excelsior. Double orange flowers. $20 \mathrm{cts}$. each, $\$ 2$ per doz. Fire Globe. Brilliant orauge flowers, $20 \mathrm{cts}$. each, $\$ 2$ per doz.

Earliest of All. Very large flowers of a perfect globe-form, and of a most beautiful deep yellow, opening the third week of April. Its early blooming, brilliant color and remarkable abundance of flowers makes it a favorite for planting and cutting. It is literally covered with flowers till the end of June. 50 ets, each. 


\section{HARDY GARDEN PINKS}

These pinks are very hardy, and bloom with wonderful freedom in May and June. The flowers are greatly varied in color and marking and are deliciously fragrant. They should be included in every garden. Care must be taken not to cover the foliage with manure or other mulching in the fall, as it will cause them to rot.

Dianthus plumısıs. A charming single Pink, with fringed petals. Flowers all of light colors but greatly varied in markings. Mixed colors, 15 cts. each, $\$ 1.50$ per doz., $\$ 8$ per 100 .

Dianthus semperflorens. Similar to the above, but darker colors in a great variety of shades and markings; charming. Mixed colors, 15 cts, each, $\$ 1.50$ per cloz., $\$ 8$ per 100 .

Double Varieties of the above, $20 \mathrm{cts}$. each, $\$ 2$ per doz.

\section{Arabis alpina fl. pl.}

This is the double form of the charming Arabis alpina and is quite as beautiful, with the advantage of lasting much longer in flower. A lovely creeping plant, covered with small, white flowers in April; splendid for carpeting edging of borders or for rockwork. 15 cts. each, $\$ 1.50$ per doz., $\$ 8$ per 100 .

\section{Polygonum Auberti}

A great improvement on the Polygonum Baldschuanicum. The flower-trusses are larger, the flowers pure white; it grows still more rapidly, and does not suffer from the illness which makes the leaves wither and drop from the old variety. A plant in full flower gives the impression of being altogether covered with hoar-frost. As a porch climber or used as a cover to old trees and stumps it is a splendid addition to our hardy vines. $75 \mathrm{cts}$. each.

\section{Campanula rotundifolia Hostii}

A beautiful variety of "Blue Bells of Scotland." 15 cts. each, $\$ 1.50$ per doz.

\section{Centaurea montana alba}

The white variety of the perennial Cornflower. $15 \mathrm{cts}$. each, $\$ 1.50$ per doz.

\section{Myosotis palustris grandiflorus}

A form of the Forget-me-not, with larger flowers than the old variety. $10 \mathrm{cts}$. each, $\$ 1$ per doz., $\$ 7$ per 100 .

\section{Pentstemon pubescens}

A very showy variety, with rosy purple flowers, blooming in July and August. $15 \mathrm{cts}$. each, $\$ 1.50$ per doz.

\section{Pennisetum Japonicum}

This new hardy grass is very desirable. It grows 4 feet high, with slender, graceful foliage and showy plumes thrown well above the leaves. Most valuable for adding variety to the garden planting. 25 cts. each, $\$ 2.50$ per doz.

\section{Primula frondosa}

A beautiful hardy Primrose, with heads of rosy lilac flowers rising from tufts of silvery foliage. $15 \mathrm{cts}$. each, $\$ 1.50$ per doz.

\section{Stenanthium robustum (MOUNTAIN FEATHER FLEECE)}

This remarkably hardy perennial is without doubt one of our best new introductions, and may be classed with the showiest of all herbaceous plants. As the buds begin to unfold, they are quite upright, and of a light green tinge, gradually becoming whiter until at last they burst forth into a veritable snowbank of drooping, fleecy bloom of the purest white, the panicles of ten 2 to 3 feet long. After several weeks the flowers, as they ripen, turn to shades of pink and purple. It is a vigorous perennial, attaining a height of 5 to 8 feet, and is absolutely hardy throughout the United States and Canada.

The Mountain Feather Fleece is of easy cultivation, but takes some time to become well established, and, if given plenty of food, makes a wonderful show equaled by few plants of any description. It prefers a moist and partially shaded position. It would be impossible to give an idea of the wonderful effect of a large mass of Stenanthiums when in full bloom, as no description conveys the beauty of the delicate, feathered, drooping flowers. Strong plants, 40 cts. each, $\$ 4$ per doz.

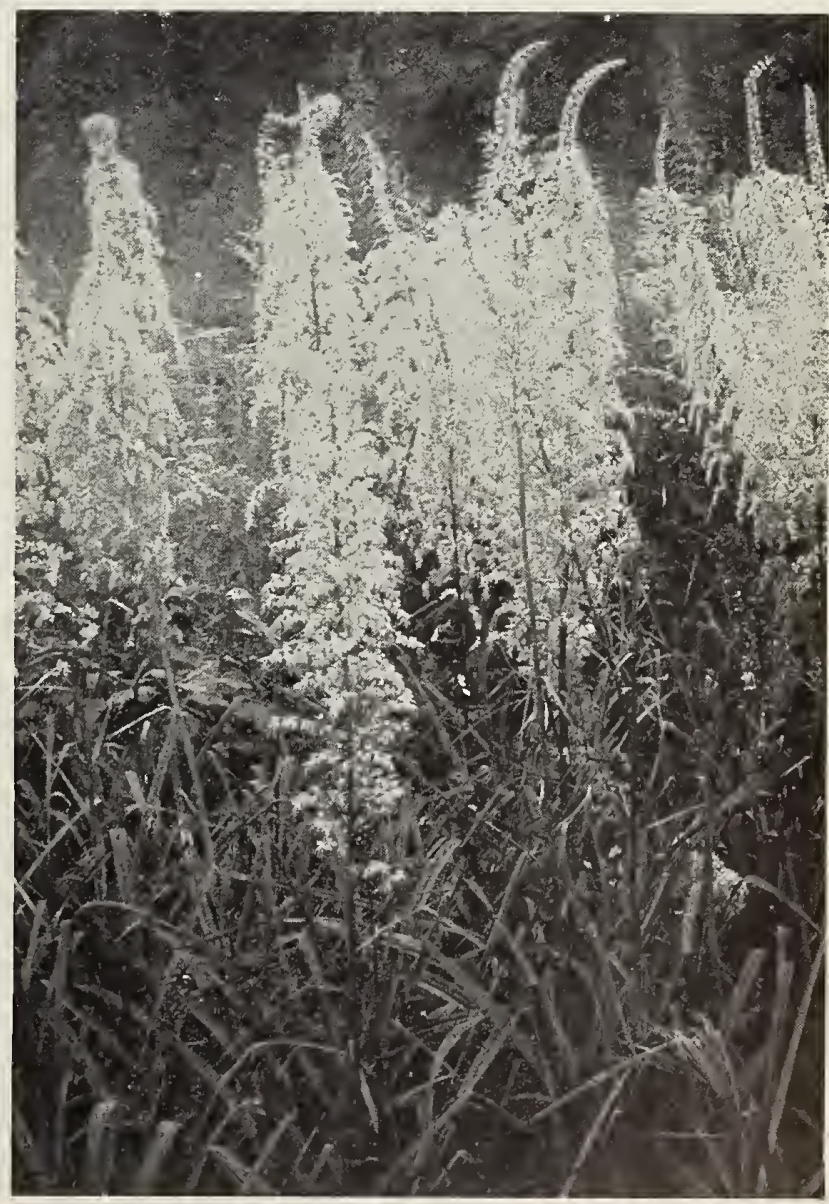

Stenanthium robustum 


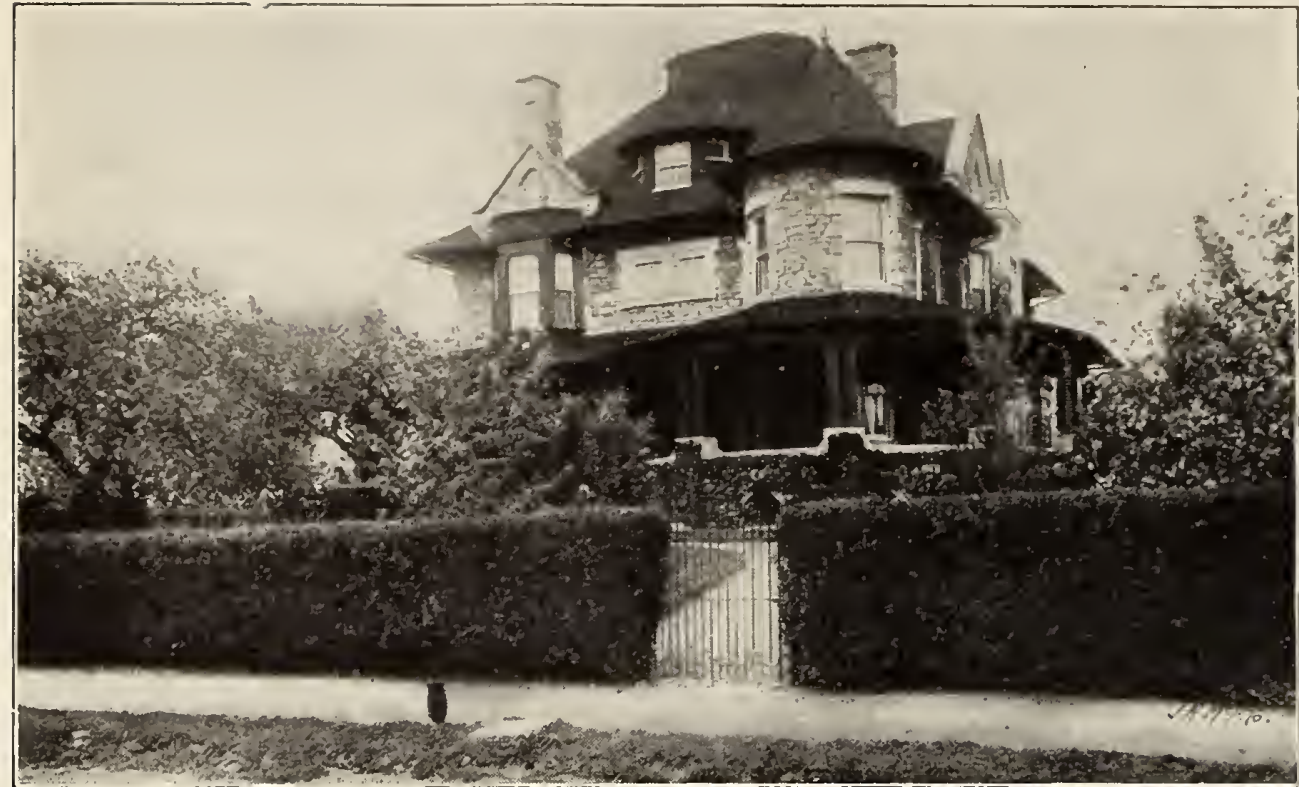

Ligustrum Amurense

\section{Ligustrum}

\section{Amurense}

(AMOOR PRIVET)

A more slender grower than the eommon Privet. Hardier than the California, while the foliage is finer and of a lighter green, and retains a better eolor during the winter. It makes a more satisfaetory hedge than the California, and should be more extensively planted. We offer the true variety. The Privet generally sold in the South for Amoor River is Ligustrum Chinense, and is not hardy in the North; but this variety is absolutely hardy, the hardiest of all the Privets. 15 ets. each, $\$ 1.50$ per doz., $\$ 8$ per 100 ; extrastrong, \$2 per doz., \$12 per 100.

\section{New Rose Killarney}

Probably no Rose has ever taken sueh a prominent plaee so quiekly as Killarney. It is already one of the most popular of our Garden Roses, and also one of the leading varieties for winter eut-flowers. It is perfeetly hardy in this latitude; in growth it is strong and robust, and as free-flowering as any Rose we know. In eolor it is a sparkling, brilliant imperial pink; the blooms are large, the buds long and pointed; the petals very large, and of great substanee, and just as handsome in the full-blown flower as in the bud form. In all ways Killarney is one of the most desirable Roses for growing in the garden. 35 ets. each, $\$ 3.50$ per doz. Potgrown plants, realy in May, 20 ets. each, $\$ 2.25$ per dloz., $\$ 16$ per 100 .

\section{Phlox ovata Carolina}

This native Phlox is one of the really good things, and is extremely valuable either for the garden or naturalizing. Its rosy pink flowers are produeed in the greatest profusion in June and last for almost a month. In bloom, the plant is about 15 inches high. 15 ets. eaeh, $\$ 1.50$ per doz., $\$ 10$ per 100.

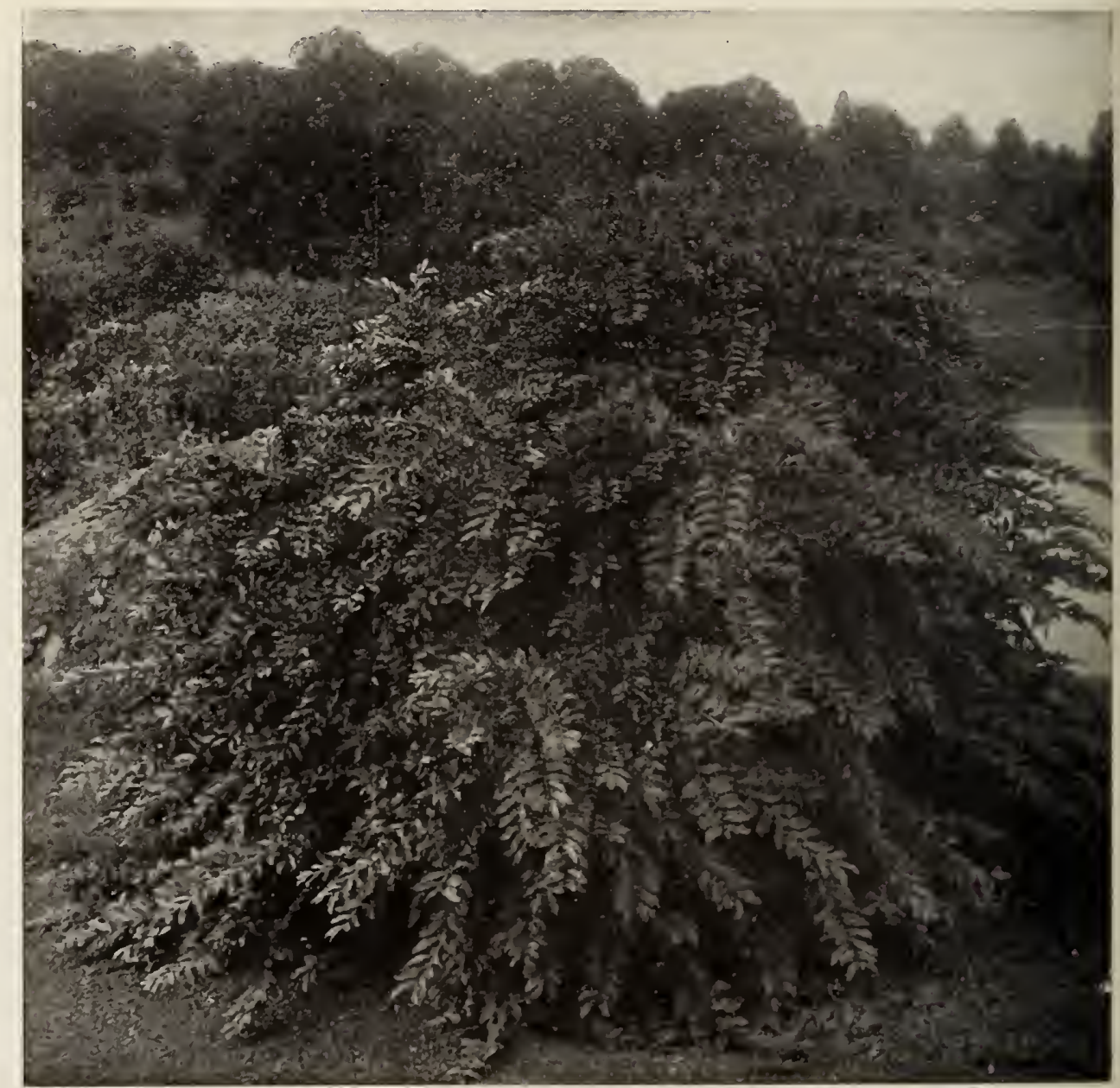

Regel's Privet (See page 9) 


\section{New Rugosa Rose, "Blanc Double de Coubert"}

The very desirable qualities of the Rugosa Roses have led the hybridizers to attempt the production of new varieties, and many Rugosa hybrids have been offered, but with a single exccption they are like the play of Hamlet with Hamlet left out. New colors and forms of flowers have been produced but the vigor and all the desirable qualitics of the Rugosa parent have been lost. The exception is the Rose named above, which is identical with the Rugosa species in foliage, habit and vigor, but has semidouble, pure white flowers which are most deliciously fragrant. The flowers are produced frecly throughout the season. On our grounds it is the first Rose in bloom in spring and the last in the fall. We have known for some years that this was a most valuablc Rose, but the stock was so scarce that we didn't dare say much about it. Valuable for grouping or planting in the shrubbery, and makes a most attractive untrimmed hedge. 35 cts. each, $\$ 3.50$ per doz., $\$ 25$ per 160 .

\section{Japanese Cherry}

The double-flowering Japanese Cherrics are beautiful beyond description, and nothing is more free-flowering-even the smallest are covered with the lovely white or delicatc pink flowers early in the spring, before the leaves appear. This is the flowering tree which is grown to such an extent in Japan, and of which so much has been said by travelers to that country. $75 \mathrm{cts}$. each, $\$ 8$ per doz.

James Veitcs. A magnificent variety of the above, undoubtedly the most beautiful of all the flowering Cherries. $\$ 1.25$ each.

\section{Large-Flowered Clematis}

We have secured a limited stock of extra-large and strong plants of the following: 75 cts. each, \$8 per per doz., except where noted Jackmanii. The well-known purple
variety.

Fairy Queen. White, lilac burs. A particularly handsome Clematis.

Henryi. Pure white; extra large.

M. Koster. Bright rosy carmine; very free-flowering variety.

Ville de Lyon. Fine new variety; brilliant carmine-red; strong grower. $\$ 1$ ea. Sieboldii. Lavender-blue.

\section{Climbing Hydrangea}

We have at last succeded in getting a stock of the rare Schizophragma hydrangeoides, known as the Climbing Hydrangea. It is one of the rarest and most beautiful vines, having large flower-heads similar to those of Hydrangea Hortensia, and will make a most splendid adornment to the porch Fine, strong, pot-grown plants, 50 cts. each, $\$ 5$ per doz.

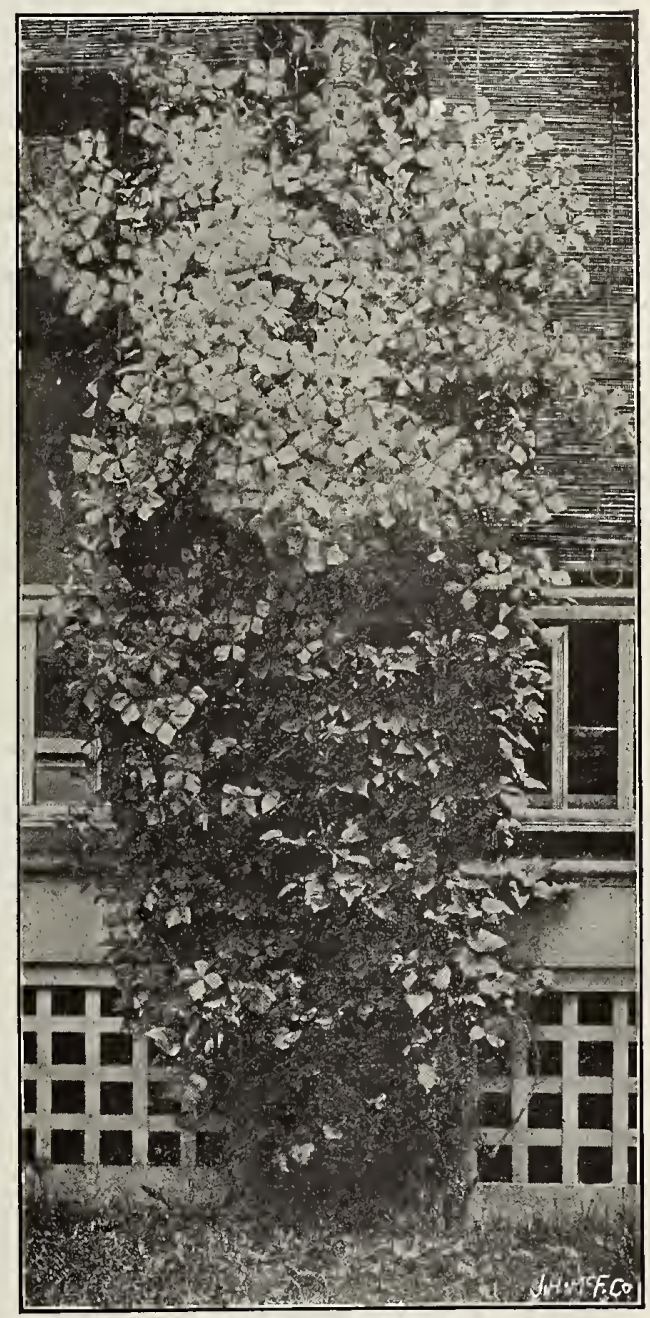

Large-flowered Clematis

\section{Hydrangea scandens}

This is the true climbing Hydrangea, one of the rarest and most difficult vines to obtain. We have succeeded in getting a small stock from Japan. It is of slow growth, but a plant will eventually cover the end of a house and is wonderfully beautiful when in bloom. Strong plants, 75 cts. each.

\section{Baby Crimson Rambler}

This Rose is a cross between Crimson Rambler and Gloire de Polyantha, showing all the qualities of Crimson Rambler and at the same time flowering perpetually as a Polyantha Rose. Madame N. Levavasseur, however, is not a climbing Rose; it does not grow higher than 2 to $21 / 2$ feet, forming a lovely bush, all covered with flowers and blooming from spring until frost. Strong plants, $25 \mathrm{cts}$. each, $\$ 2.50$ per doz., $\$ 18$ per 100 .

\section{Specimen Honeysuckles}

We have secured in Europe a limited quantity of extra-large and fine plants of the beautiful but very scarce Lonicera Heckrotti. 50 cts. each, $\$ 5$ per doz.

\section{Speaking of Shrubs}

Miss Jekyl, in her book, Wood and Garden, says: "What a precious thing this fine old Mahonia is! What should we do in winter without its vigorous masses of grand foliage in garden and shrubbery, to say nothing of its use indoors. . . When one reflects that Mahonia aquifolium is individually one of the handsomest of small shrubs, that it is at its very best in midwinter, that every leaf is a marvel of beautiful drawing and construction, and that its ruddy winter coloring is a joy to see; and further, when one remembers that in the spring the whole picture changes-that the polished leaves are green again and the bushes are full of tufted masses of brilliant yellow bloom and fuller of bee-music than any other plant then in flower. . . It is the only hardy shrub I can think of that is in one or other of its varied forms of beauty throughout the year." 


\section{Evergreens Specially Prepared for Transplanting}

The following Evergrecns have all been speciaily prepared for final transplanting by shearing and frequent transplanting, and will be shipped with ball of earth about their roots. They are from leading European and American nurscries, and if wanted in quantity must be ordered before March 1. Such evergreens are much higher priced than those grown and handled in the ordinary way, but really they are eheaper and give much greater satisfaction, for, if planted with any care whatever, every trec will grow.

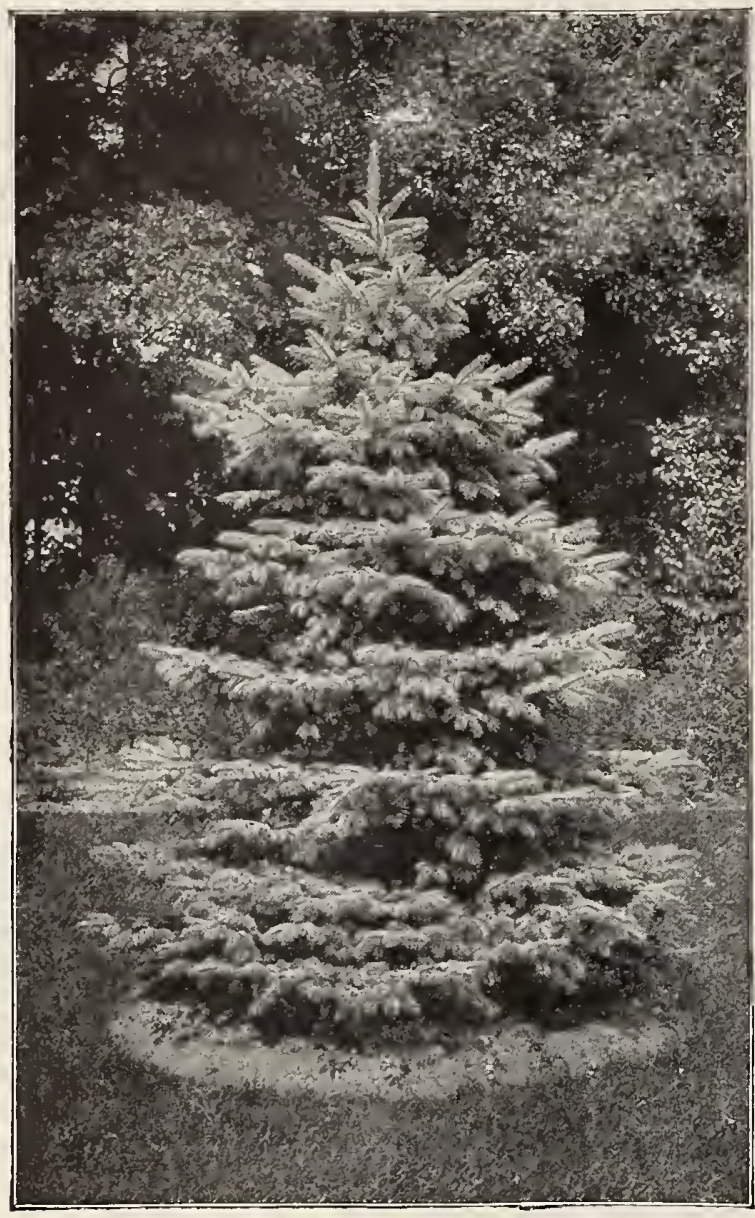

Koster's Blue Spruce

Juniperus Sabina. A prostrate Juniper of striking beauty. Each Specimens, 3 feet. Extra-fine plants ............. $\$ 250$

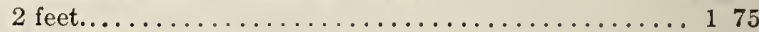

Virginiana elegantissima. Rare and beautiful. 3 feet... 250 Virginiana Schotti. Distinct and fine. Splendid, broad

specimens. 3 fect....................... 500

Virginiana tripartita. Specimens, 3 feet........... 400

Virginiara glauca. Blue form of the "Red Cedar." 4 feet.. 300

2 fect............................... 150

procumbens (Creeping Juniper). Pot-plants........ 40

PICEA Alcockiana. 4 to 5 feet................... 300

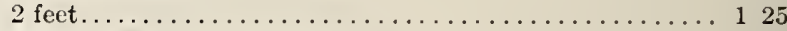

excelsa inverta (Weeping Norway Spruce)........... 150

polita. 2 feet......................... 150

pungens glauca (Koster's Blue Spruce). The Koster Blue

Spruce is the blucst of all Blue Spruces. 3 feet...... 500

$2 \frac{1}{2}$ feet......................... 400 orientalis. A splendid Spruce, with beautiful green foliage.

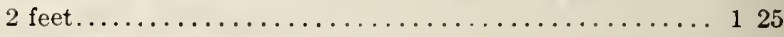

PSEUDOTSUGA Douglasii glauca.

elegans. A beautiful form of the Douglas Spruce. $2 \frac{1}{2}$ feet. 300

RETINOSPORA obtusa gracilis. Fine specimens, $2 \frac{1}{2}$ feet... 250

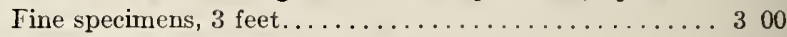

Crippesi. Fine specimens, $2 \frac{1}{2}$ feet............... 300

plumosa aurea. Fine specimens, $2 \frac{1}{2}$ feet.......... 150

Fine specimens, 2 feet.................... 125

pisifera aurea. Fine specimens, $2 \frac{1}{2}$ feet........... 200

TAXUS Canadensis Washingtoni. A fine dwarf Yew with variegated foliage. $1 \frac{1}{2}$ feet..................... 200 cuspidata. A fine form of the Japanese Yew, and perfectly hardy. 2 feet............................ 200

Canadensis. The dwarf Canadian Yew............ 35

TSUGA Canadensis (Hemlock Spruce). Sheared and bushy.

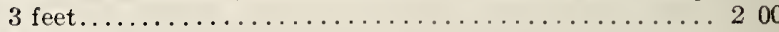

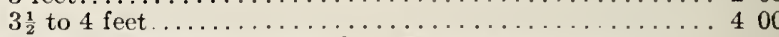

Canadensis Sargenti pendula. (Weeping Hemlock Spruce.) Very rare and beautiful.................... 150

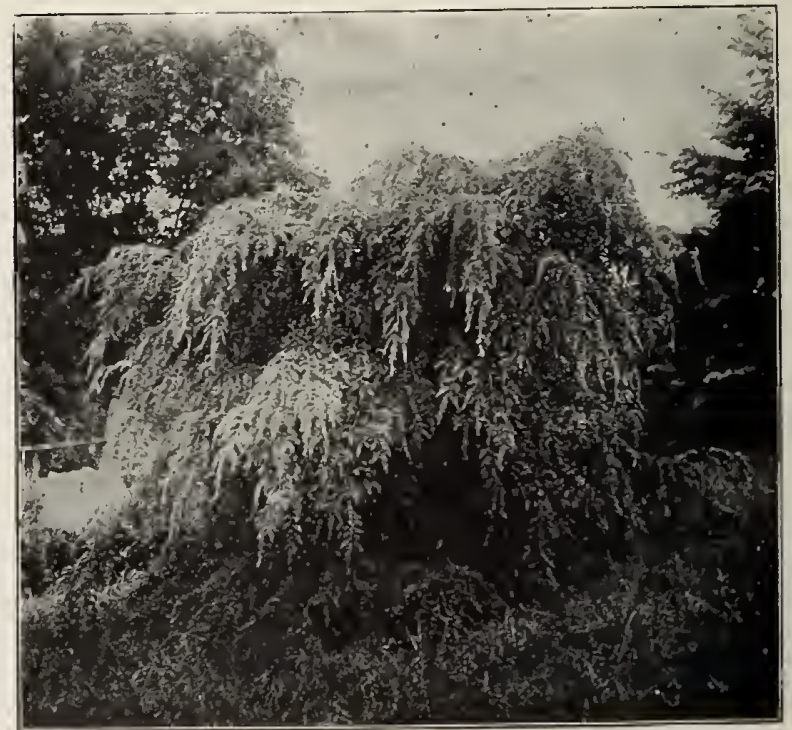

Weeping Hemlock Spruce 


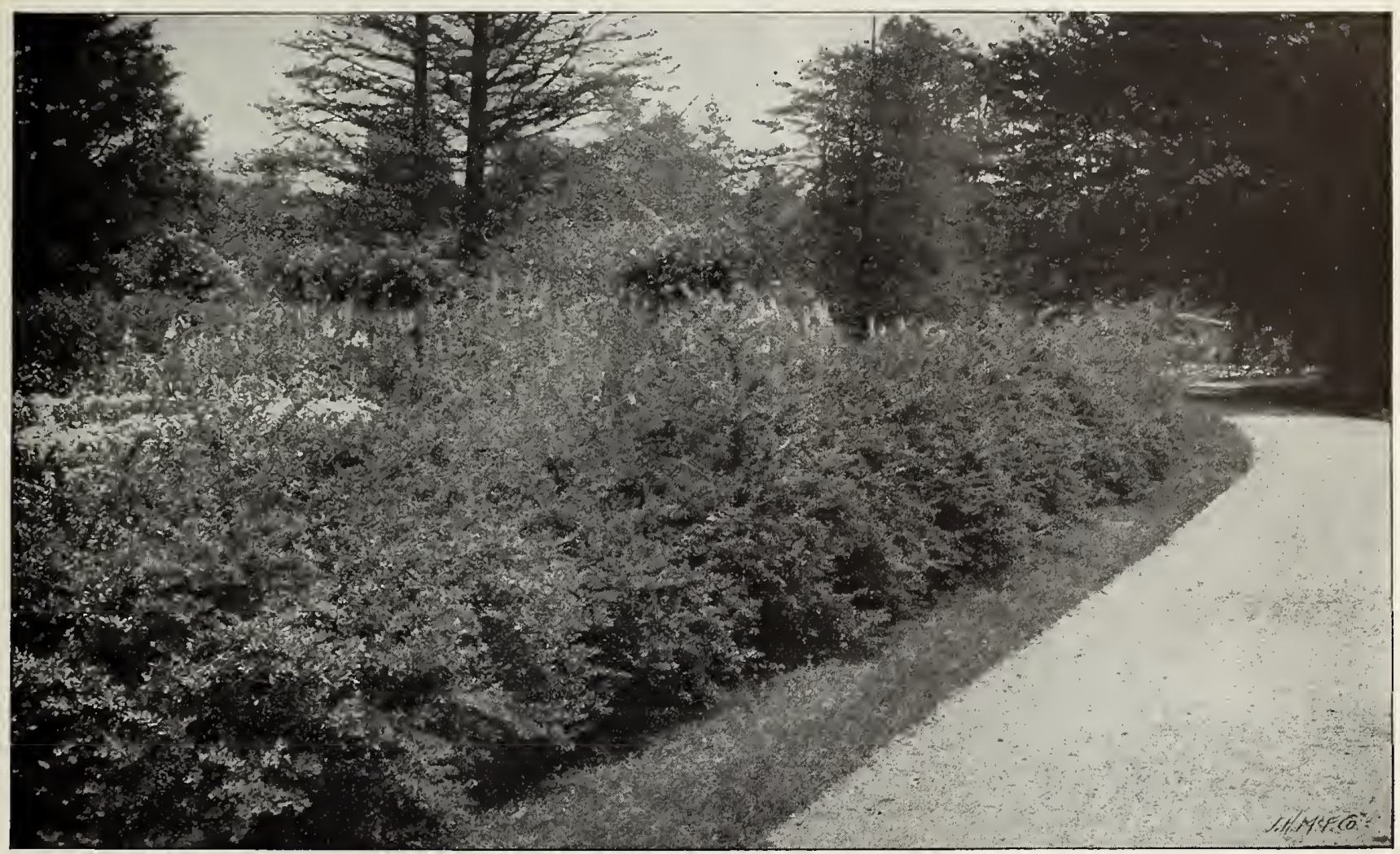

Japanese Barberry Hedge

\section{The Best Hedges}

\section{Japanese Barberry}

We are frequently asked to recommend the best shrub for hedge planting, and, after many years' experience, we are decidedly of the opinion that the Japanese Barberry, Berberis Thunbergi, is the best hedge plant in existence, and either as an ornamental, defensive, trimmed or untrimmed hedge, it is unsurpassed. As an ornamental hedge it is beautiful throughout the year, its abundant crop of bright red berries makes it even more attractive in the winter than the summer. Its compact growth and thorny branches make a defensive hedge that will turn cattle after five years' growth. As an untrimmed hedge, it requires no attention except an occasional cutting of a few straggling branches. The natural growth is so dense and even that it forms a perfect hedge without shearing, but if a formal hedge is desired, by shearing, it can be made as even as a stone wall. This Berberis is absolutely hardy, of the easiest culture, and will grow in any soil or situation. It will stand considerable shade and can be grown under trees if not planted too closely to the trunks. It is of slow, compact growth, but will eventually attain a height of 5 or 6 feet. It is also one of the very best of shrubs for general planting. For a hedge, plant a single row 18 inches apart in the row. We have a very large stock of fine plants, which we offer at $\$ 8, \$ 10, \$ 13$, and $\$ 16$ per 100 , according to size. Special prices quoted on lots of 1,000 to 10,000 on application.

\section{Regel's Privet}

Regel's Privet is not only the best Privet, but is also one of the very best shrubs for many purposes that we know of. Is perfectly hardy, of most beautiful pendulous habit and splendid foliage. It is of vigorous growth and will thrive in either sun or shade. In good soil it will attain a height of 8 or 10 feet, and spread almost as great. It is fine as a specimen or for planting in masses in the shrubbery, but its greatest value is for hedging. As a hedge plant it is unsurpassed. It can be kept closely trimmed, or trimmed but little, when it will preserve its natural drooping character which is most graceful and beautiful. A partially trimmed hedge of this Privet on the grounds of $\mathrm{Mr}_{\mathbf{r}}$. Clarence Byrnes, Sewickly, Pa., we think one of the handsomest hedges we have ever seen. On account of its spreading habit this Privet makes a hedge solid to the ground whether it is sheared hard or not. We can not understand why people continue to plant California Privet, which is inferior in every respect and not reliably hardy. Regel's Privet is somewhat higher-priced, but on account of its spreading habit it requires only half the quantity that it does of the California Privet to plant a hedge. For a hedge, plant Regel's Privet 18 inches apart in a single row. We offer a splendid stock at the following prices: 24 to 36 inches, 20 cts. each, $\$ 2$ per doz., $\$ 14$ per $100 ; 12$ to 18 inches, 15 ets. each, $\$ 1.50$ per doz., $\$ 10$ per 100 . (See illustration on page 6 .)

\section{Anchusa Italica, Dropmore Variety}

One of the most important hardy plants of recent introduction, and a grand improvement on the original type of $A$. Italica, or Italian Alkanet, and a plant which, on account of its remarkable freedom of flowering and its beautiful blue color, is sure to become one of our most popular hardy perennials. It attains a height of 5 to 6 feet, and produces its pretty blue flowers, which are from 1 to $1 \frac{1}{4}$ inches in diameter, throughout the entire summer. 25 cts. each, $\$ 2.50$ per doz, 


\section{Extra-Fine Specimens MAGNOLIA}

STELLATA. Of this exquisitely beautiful dwarf white Magnolia we have sccured some finc bushy specimens. 21 feet, $\$ 1.50$ each.

FINE BUSHY SPECIMENS, spccially prepared for transplanting, in the following varictics: Alexandrina, whitc and red; Norbertiana, white, purple at base of petals; Soulangeana, whitc, with dcep flush of purple; Speciosa, white, blush at base of petals, and Speciosa nova, white. $\$ 3$ each.

LENNE. Reddish purplc. \$4 each.

CONSPICUA (Yulan). Pure white. \$5 each.

The Chinese Magnolias are the most beautiful of all spring flowering trees, but as ordinarily grown in American nurseries, almost impossible to transplant successfully. The above, imported from Europe, have been specially prepared for transplanting and are certain to grow.

\section{Wistaria Sinensis}

We have a few extra-large plants of the wcll-known purplc Chinese Wistaria, with extra-heavy tops. These will grow rapidly and bloom quickly. $\$ 1$ each.

\section{ROSES}

STANDARD CRIMSON RAMBLER. This Rose, on aceount of its frec-flowering qualities and vigorous growth, makes a bcautiful object when grown as a standard. Fine strong plants, $\$ 1$ each.

CRIMSON RAMBLER. A few cxtra-strong plants, 50 cts. each, $\$ 5$ per doz.

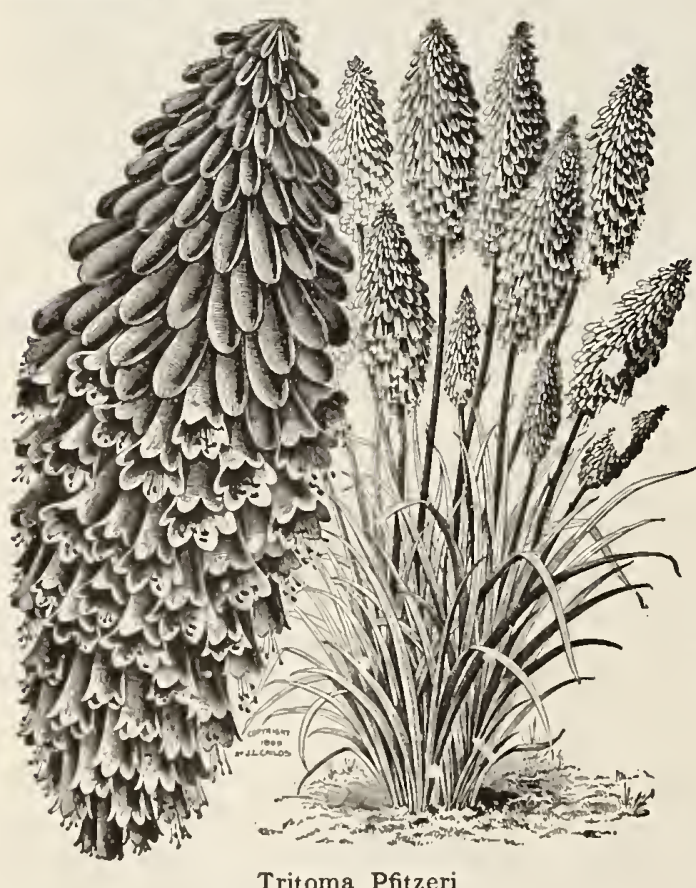

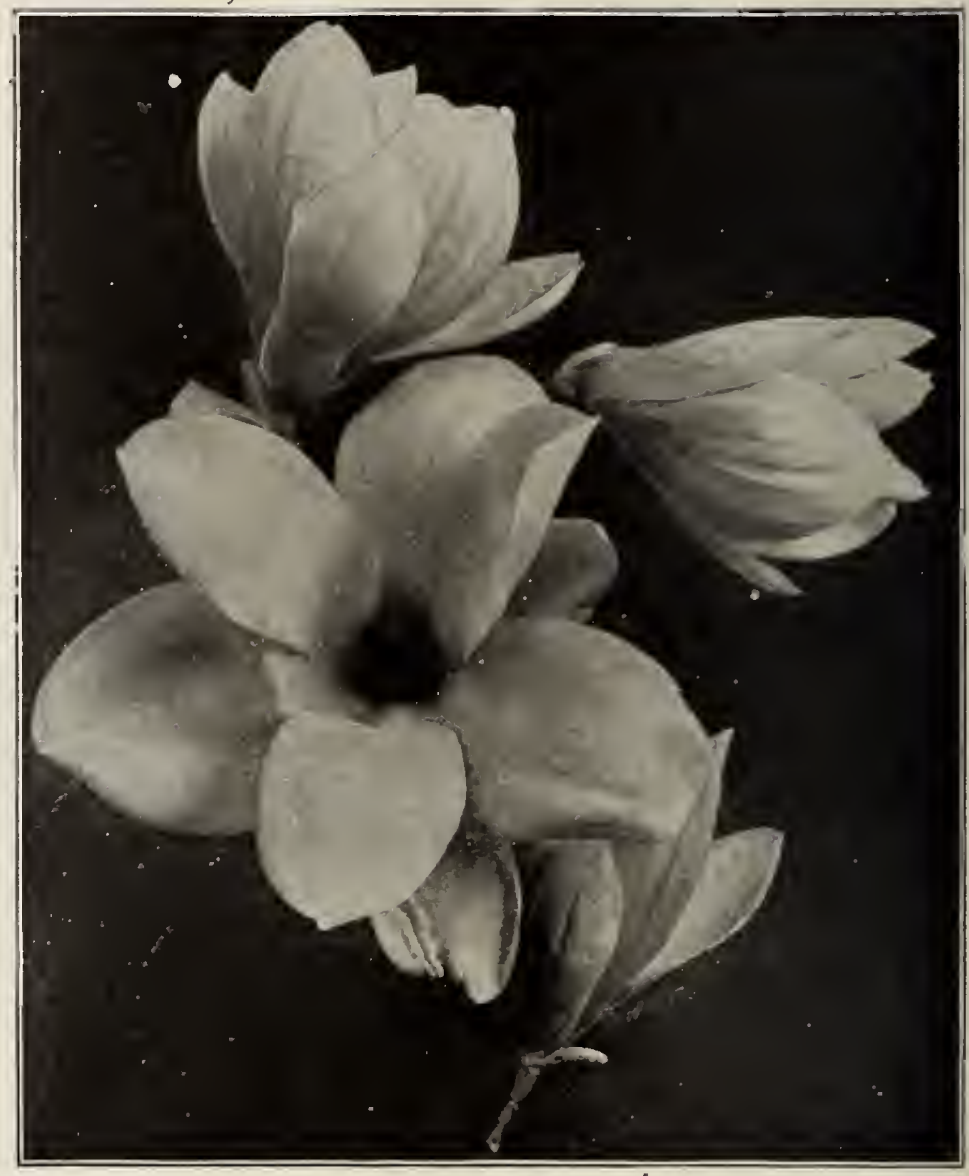

Chinese Magnolias

Tritoma Pfitzeri (Flame Flower, or Torch Lily)

This new Tritoma is undoubtedly one of the most valuable introductions of recent years. Tritoma Uvaria, or "Red-Hot Poker" plant, is highly prized on account of its picturesque appearance and its blooming so late in the fall after almost everything else is gone. This new variety is a great improvement in every respect. The flowers are much more refined and beautiful and are produced in the greatest profusion from carly summer until late fall, eoming into bloom at least two months before the older variety. It is equally desirable for garden effects or for cut-flowers. The flower-spikes are of gigantic sizc, frequently $4 \frac{1}{2}$ feet high, with heads of bloom over 12 inches long, of a rich orange-scarlet, shading to salmonrose on the edge; a first-elass acquisition. This plant is not quite hardy and should be proteeted in winter with a covering of leaves, or ean be taken up, packed in sand and stored in a cold cellar over winter. 20 cts. each, $\$ 2$ per doz., $\$ 15$ per 100 .

\section{Prunus maritima}

This is the Beach Plum, which grows wild very plentifully in some localities on the scashore. It bears an edible fruit, which makes a very good jam, and I have secn it in fruit when only two feet high; but its chicf value is its beautiful white flowers, with whieh it is literally eovered early in the spring. We have secured a fine stock of nursery-grown plants. 25 cts. each, $\$ 2.50$ per doz.

\section{Viburnum Opulus nanum}

A most interesting little Snowball, never growing over 2 fcet high, and as compact and globular in form as a sheared evergreen. Where a small shrub of formal shape is desired, nothing can be better. $35 \mathrm{cts}$. each, $\$ 3.50$ per doz.

The Blue Rose. Is it blue? Possibly, but it belongs to that class of blues that one gets after a night of dissipation. We The Blue Rose. Is it blue? Possibly, but it belongs to that class of blues that 


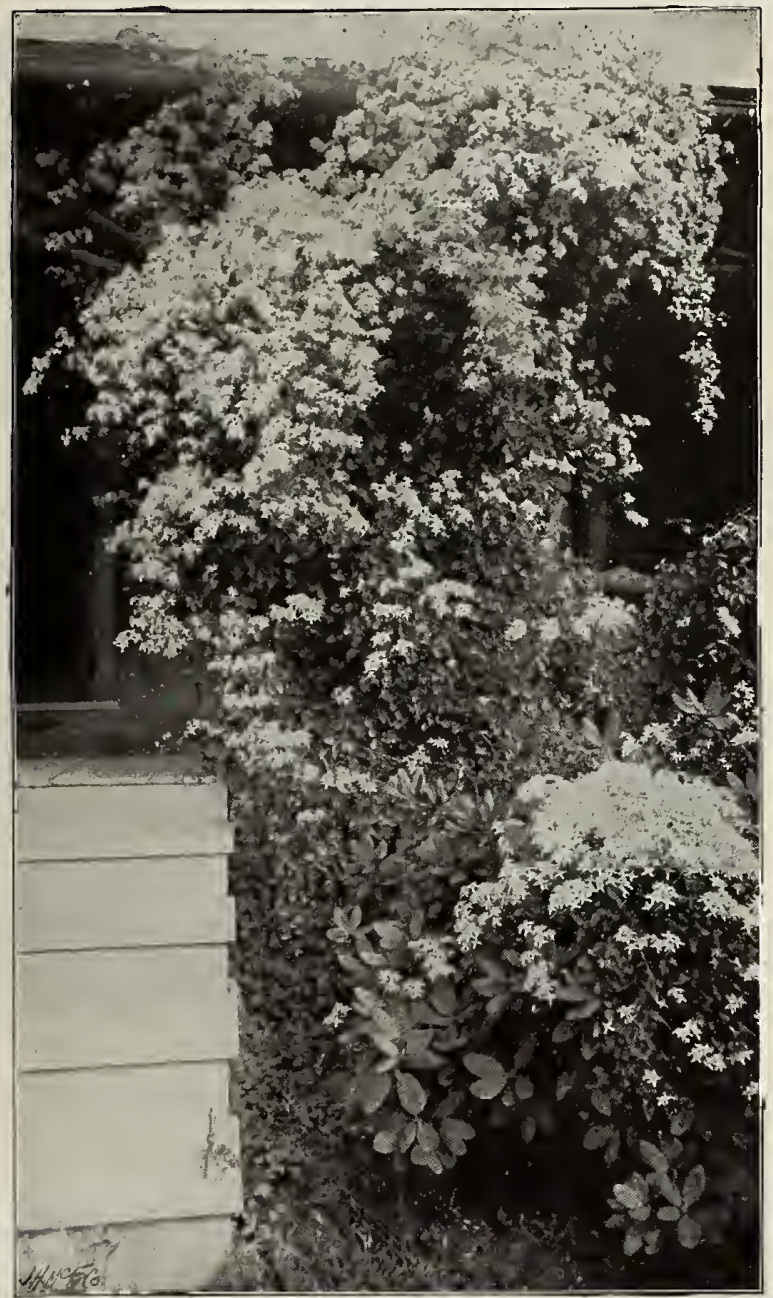

Clematis paniculata

\section{Clematis paniculata}

This handsome hardy climber is one of the choicest and most satisfactory climbing flowering plants we know. The plant is of strong, rapid growth, with small, dense, cheerful green foliage, giving it a grace and elegance possessed by no other hardy climber, and, even did it not flower at all, it would be one of the most desirable vines. The flowers appear in the greatest profusion duing August and continue until late in the fall, are of white color and most deliciously fragrant. The plant succeeds in almost any position; not only is it well adapted to run up all kinds of supports, but it is just as useful for planting among rockwork, sloping banks, or, in fact, in any position where a graceful vine is desired. Each Doz 100

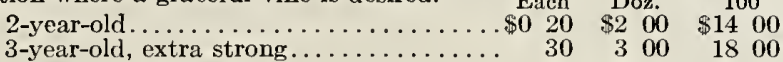

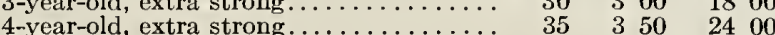

\section{The Oak-Leaved Hydrangea (Hydrangea quercifolia)}

The Oak-leaved Hydrangea, although a native shrub, is one of the rarest, and, in our estimation, one of the most beautiful and picturesque in cultivation. Flowers, foliage and habit all combine to make it the most striking, and it should be included in every planting list. It is rather dwarf and spreading, and plants over 3 feet high are not often seen. The foliage is distinctly beautiful, the leaves being somewhat of the shape of oak leaves, and slightly white on the under surface. As the plants gain age and strength they assume a picturesque relation to the surroundings that gives them unique value. We have secured a small stock of nice plants, which we do not expect will last half through the season; therefore, early orders are suggested to avoid disappointment. 50 cts. each, $\$ 5$ per doz.

\section{Pot-Grown Wistarias}

We have secured a few specimen Wistarias in Europe, grown in pots. These are extra large, and if the roots arc kept confined will bloom at once. $\$ 1.50$ each.

\section{Salix Salamoni}

This is a new variety of Weeping Willow, of remarkably rapid growth. A tree of it on our grounds, four years old from a cutting, is 20 feet high. It is not so pendulous as the old Weeping Willow, but is much handsomer. $75 \mathrm{cts}$. each.

\section{Cornus stolonifera pèndula}

This is a new variety of dwarf Dogwood originating in our nursery, which is very valuable for planting on the banks of streams or ponds, or on steep banks. It is a compact, low-growing shrub with pendulous branches. As it spreads from the roots it soon covers a large area closely. It is of the easiest culture and will thrive in almost any soil or situation. 20 cts. each, $\$ 2$ per doz., $\$ 14$ per 100 .

\section{POLYGONUM}

BALDSCHUANICUM. A hardy climber of recent introduction from the mountains of Turkestan; it of is rapid growth, frequently attaining a height of 10 to 12 feet in one season. The stems are twining and cling for support to any object within reach. Every branchlet terminates in a panicle of white, foamy flowers, which are produced during August and September. Strong plants, 75 cts. each.

MULTIFLORUM. Another grand addition to our list of rapidgrowing hardy climbers, attaining a height of 15 to 20 feet in a single season, and one which seems peculiarly adapted to our climatic conditions. It has bright green, heart-shaped foliage, which does not appear to be attacked by any insect pest, and during September and October produces masses of delicate white flowers in trusses at the axils of every leaf. Erroneously this plant has been distributed by some growers as $P$. Baldschuanicum, from which it is quite distinct. Good young plants, 25 ets. each, $\$ 2.50$ per doz.

\section{Hardy Bamboos}

BAMBUSA AUREA has straight, erect, slender stems, with very short internodes, which have attained heights of 12 to 15 feet in this country. It is one of the most graceful of the genus and particularly effective when planted in large, bold masses. Large plants, \$2.

BAMBUSA JAPONICA (Metake of gardens). One of the best known of all the hardy Bamboos. The stems are often 15 feet high. with internodes 6 to 8 inches long, and with tapering leaves a foot long, smooth and shining above, glaucous beneath. It forms fine clumps when sheltered from the east wind, and will grow in drier situations than most Bamboos. $50 \mathrm{cts}$. each; large plants, $\$ 1$.

\section{WATER-LILIES}

N YMPH\&A candidissima. Best white......... Each $\begin{aligned} & \text { Doz. } \\ & \$ 075\end{aligned}$

Gladstoniana. White. Strong grower......... $50 \quad 500$

Marliacea chromatella. Best yellow........... $75 \quad 7 \quad 50$

Marliacea rosea. Best pink................ $100 \quad 1000$

Odorata. Common Pond-Lily ................ $20 \quad 200$

Tuberosa rosea. Exquisite shade of pink........ $30 \quad 300$

Tuberosa Richardsonii. White flowers.......... $30 \quad 300$

Devoniensis. Tender; large red flowers......... $75 \quad 750$

Dentata. Tender; large white flowcrs............ $75 \quad 7 \quad 50$

Zanzibariensis. Tender; deep purplish blue..... 150

Zanzibariensis azurea. Tender; blue .......... $75 \quad 750$

NELUMBIUM album striatum ............. 300

Album grandiflorum. Best whitc.......... 300

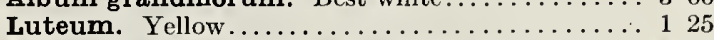

Pekinensis rubrum. Rosy carmine......... 400

Pekinensis rubrum plenum. Doublc carmine

flowers .......................... 500

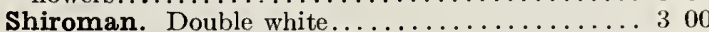

Speciosum (Egyptian Lotus)................. ${ }_{75} \quad 800$

Speciosum. Large plants.................. $150 \quad 1500$

The above are the very best of the Water-Lilies, and all that are really worth growing. 


\section{THREE GREAT ROSES}

\section{Rayon d'Or}

We lave thoroughly tested this Rose, and have no lesitation in pronouncing it the finest hardy yellow IRose in cultivation. It is not only this but it is the most beautiful ycllow Rose of any class. Vigorous-growing, with fiue foliage; blooms freely; the buds are striped with erimson but open into large flowers of the richest and most beautiful yellow. $11 \mathrm{e}$ consider it the most valuable Rose introduced in many years. $\$ 1$ each, $\$ 9$ per doz.

\section{Frau Karl Druschki}

This grand Rose is no longer a novelty, but thoroughly established as the fincst hardy white Rose ever produced. The flowers are pure white, of great size and fine form, and are frecly produeed throughout the summer. Wc have a splendid lot of dormant plants for delivery not later than Apri 10. They should be planted early in the spring. $40 \mathrm{cts}$ each, $\$ 3.50 \mathrm{per}$ doz. $\$ 25$ per 100.

\section{Baby Tausendschon}

This is the finest of all the Baby Rambler Roses. Dwarf in habit, with fine foliage that never mildews, it produces its clusters of lovely pink flowers in the greatest profusion from June until late in the fall. It is very valuable for bedding. $25 \mathrm{cts}$. each, $\$ 2.50$ per doz.

\section{SOME GOOD LILIES}

There is a tendeney to plant little else than the Auratum and Speeiosum varieties of Japanese Lilies, whieh are very beautiful, but do not bloom unti after the middle of July. There is a host of June-blooming Lilies that should be found in every garden, and none more beautiful than our graceful, dainty little native Lily, Canadense, with its spotted red or yellow

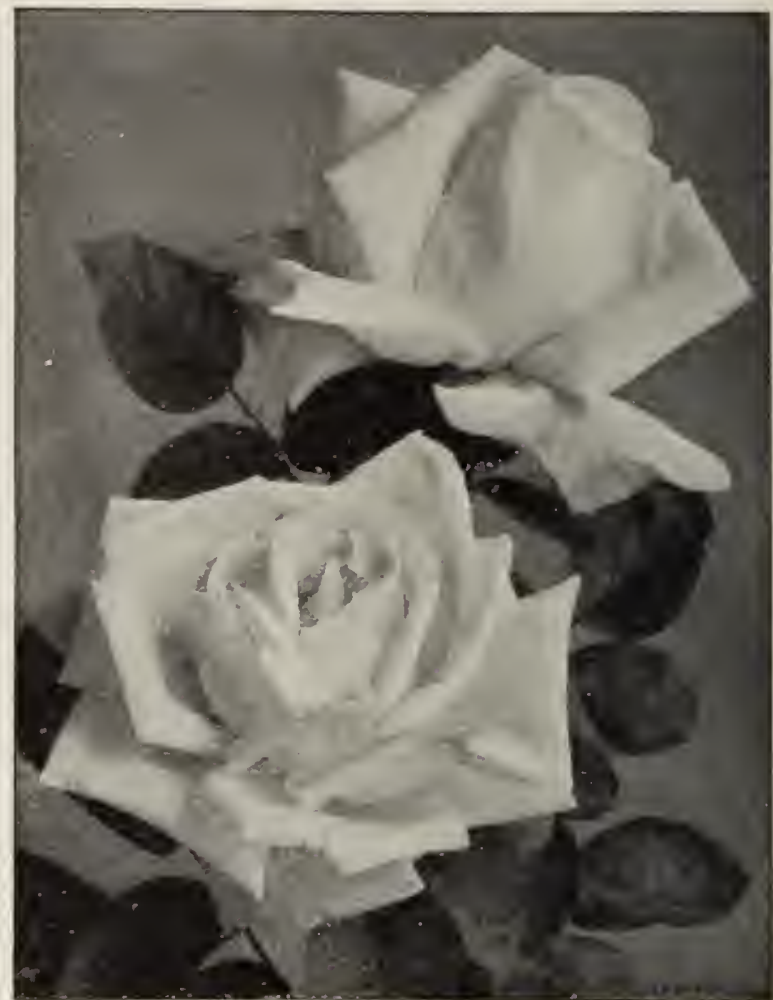

Frau Karl Druschki Roses flowers. Nothing finer for naturalizing in meadow or orehard. It will thrive in the wettest ground, and so will the splendid Superbum, also a native Lily, blooming the end of June, or early in July. We have seen the plants of this 8 feet high, with thirty or forty flowers. All varieties of Thunbergianum (Elegans) and Umbellatum Lilies bloom in June, and none are more vigorous and hardy or showier when planted in large elumps, and they are abundantly able to take eare of themselves in almost any situation; and so are all varieties of Tiger Lilies, which make bold and most effective groups. A Japanese Lily, not so wcll known, is Hansoni, but one of the most distinet and desirable. It has a triek, however, of remaining dormant for a year after it is planted; in faet, I think it always does

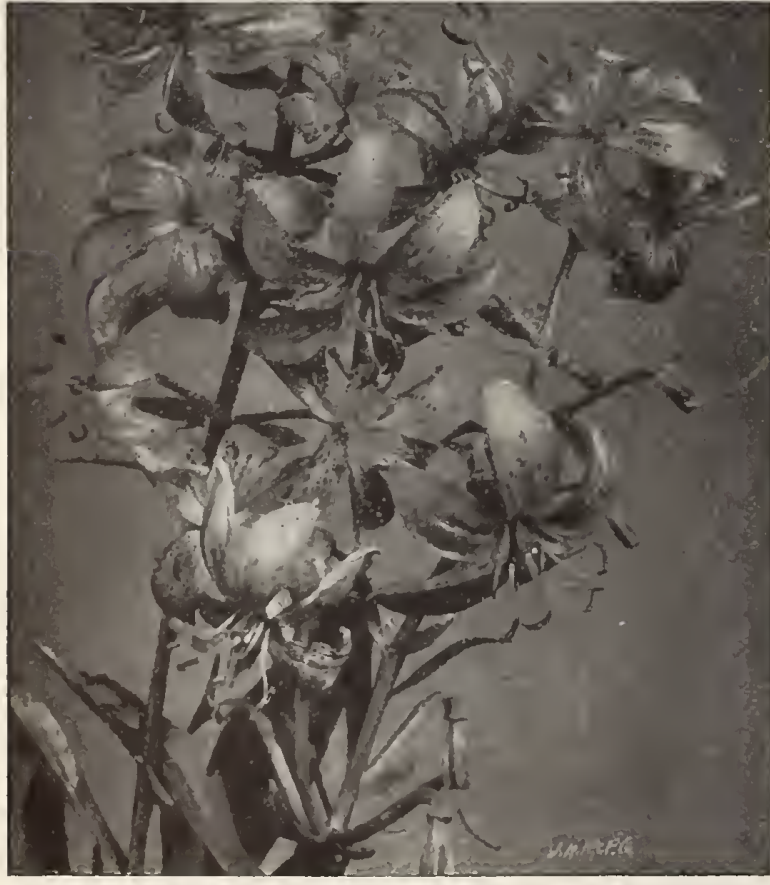

Lilium Hansoni this if planted in the spring. Henryi, the new variety from Japan, is wonderfully rigorous and fine when established, but, as yet, the bulbs are extremely searce and difficult to get. Brownii and Excelsum are two lovely Lilies, but the bulbs are getting very searce and high-prieed.

\section{PRICES OF LILIES}

Per doz. 100

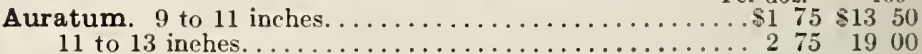

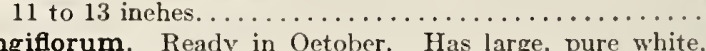

trumpet-shaped flowers like the Bermuda Easter Lily.

but is quite hardy.

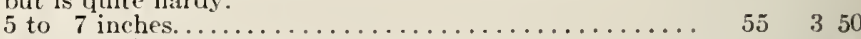

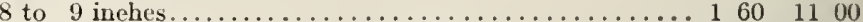

Speciosum album. Whitc. 8 to 9 inehes............ $175 \quad 1200$

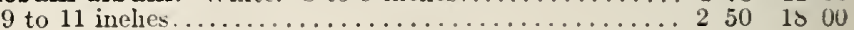

Speciosum Melpomene. Similar to Roscum or Rubrum more brilliant in eolor. 7 to 9 inclies........... 135990 9 to 10 inehes............................. $175 \quad 1300$

Speciosum rubrum, or roseum. Pink. \& to 9 inches..... 125 \& 50

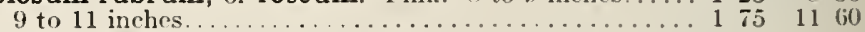

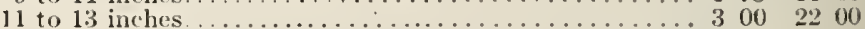

\section{Superbum Lilies}

We make an annual contract to have 25,000 bulbs of this grand Lily grown for us. This enables us to offer it at low prices, whieh makes it available for naturalizing in quantity. It is unquestionably one of the most satisfactory Lilies that ean be plauted either in the garden or in the meadows, on the cdge of woods or in any rough or wild parts of the grounds, where it will take care of itself without any attention whatever after planting. It will also thrive in wet or swampy places. It is a grand Lily, of ten growing over 8 feet hirh and produces twenty to thirty beautiful orange-red flowere in July, when flowers are apt to be rather searce. Extra-selected hulbs, $\$ 1.25$ per doz., $\$ 2.25$ for $25, \$ 7$ for $100, \$ 16.50$ for $250, \$ 27$ for $500, \$ 50$ per 1,000 . 


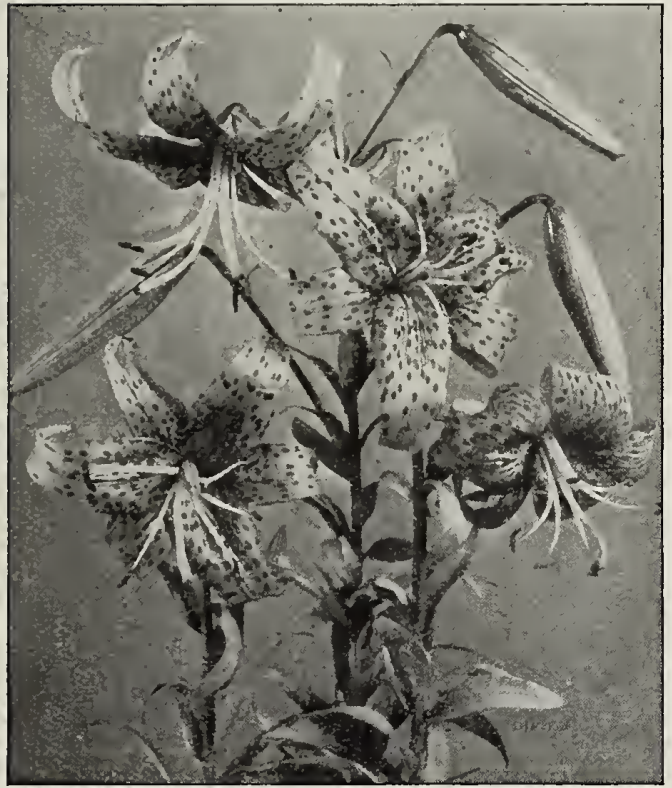

Lilium tigrinum

\section{Other Japanese Lilies}

Each Doz.

Batmanniæ. Bright apricot flowers in July. A very thrifty grower, bearing its flowers in clusters. and one of the finest for massing

for color effect................... $\$ 0 \quad 15 \quad \$ 1 \quad 50 \quad \$ 1100$

Brownii. Japanese bulbs. An extremely handsome hardy Lily, with large, trumpet-shaped flowers like those of Longiflorum or Bermuda Easter Lily; pure white inside but the outer part of the petals is a beautiful purplish brown.........................

Henryi. A new Japanese Lily that has made a sensation in Europe. Similar to Speciosum but the flowers are bright orange-yellow.

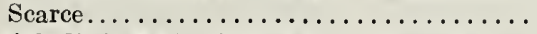

Leichtlini, Red. Orange-red, crimson spots. Somewhat of the same habit and effeect as the Tiger Lilies ...................

Leichtlini, Yellow. Neat and elegant habit; flowers pure canary-yellow, crimson spots..

Hansoni. A handsome variety, flowering in June. Has bright, rich yellow flowers; one of the best Lilies in cultivation. Bulbs sometimes remain dormant after planting, but will come up vigorously the next

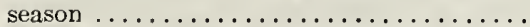

Rubellum. This is a beautiful new Lily similar to Krameri. It is unknown in this country, but in England, where it has been fully tested, it is highly praised, and it seems likely to become as popular as the Speciosum varieties; subject to Lily disease .........................

\section{European-Grown Lilies}

Thunbergianum aureum (Elegans). Yellow; dwarf. $\$ 150$ Thunbergianum grandiflorum............. 240 Thunbergianum Van Houttei.............. 150 Tigrinum flore pleno (The Double Tiger Lily). The only double Tiger Lily worth growing...........

500
EUROPEAN-GROWN LILIES, continued Doz.

100

Tigrinum simplex (The well-known Single Tiger Lily). Of the easiest culture and worthy of general planting on account of stately habit and fine effect in the landscape..................... $\$ 060$

Tigrinum splendens (Improved Single Tiger Lily). This is of more robust habit than the common Tiger Lily and has a larger flowering spike..... 65

Umbellatum erectum. Scarlet, brown spots. One of the most useful species for general garden culture.......................... 150

Umbellatum, Fine Mixture. Splendid bulbs which will produce the finest flowers.............. 125

\section{Native and American-Grown Lilies}

Canadense flavum. Our dainty, beautiful native Lily. Doz. 100 Graceful and charming yellow flowers. Fine for naturalizing in meadows and for the garden......\$1 $00 \$ \$ 600$

Canadense rubrum. Red flowers............. $150 \quad 1000$

Canadense, Mixed ..................... $75 \quad 550$

Elegans bicolor. Apricot, spotted............. $175 \quad 1100$

Elegans robusta. Crimson-black; fine.......... $175 \quad 1100$

Philadelphicum. Native Lily. Orange-red, black spots............................. $100 \quad 700$

Tenuifolium. A beautiful, graceful Lily, with crimson reflex flowers. One of the choicest Lilies, but dies out in a year or two, but can be renewed fiom seed.

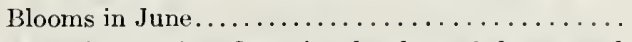

Wallacei. Very free-flowering, hardy, and showy; each bulb sends up many stems which bear several lovely vermilion-orange flowers............... 125

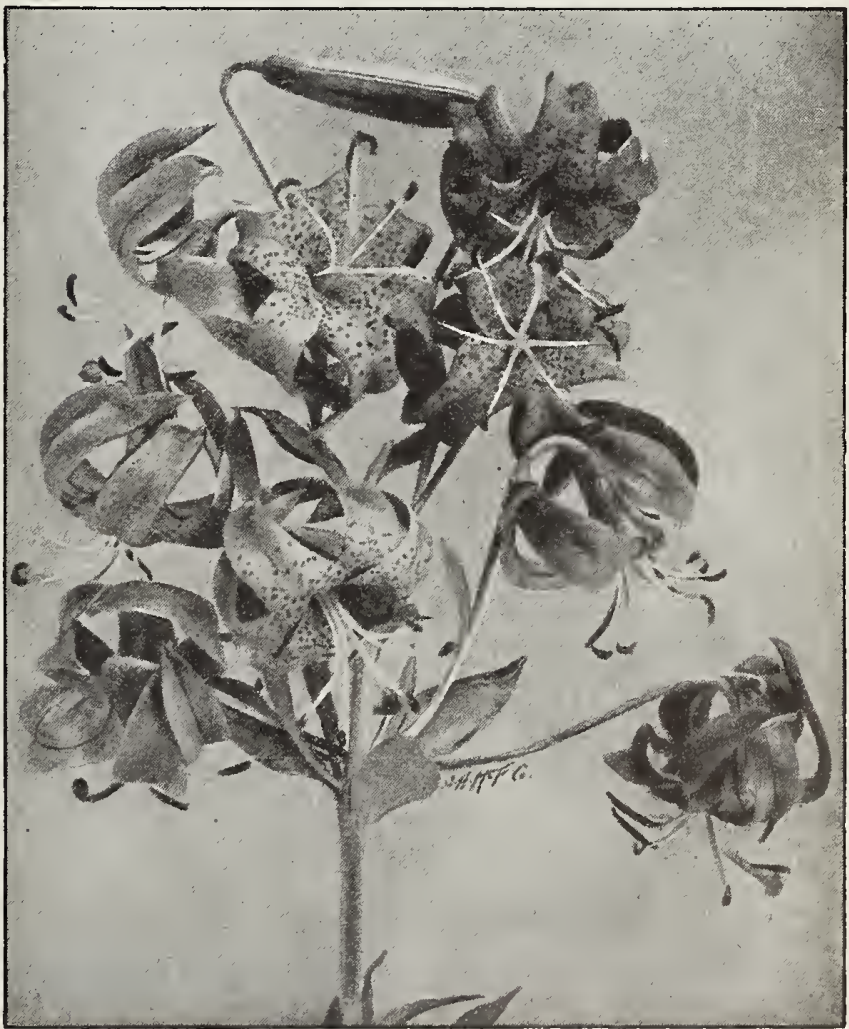




\section{Rhododendron Catawbiense}

All things considered, this is the most desirable Rhododendron in cultivation. It is a native variety, growing wild in the southern mountains. It is absolutely harrly and hardier than any other variety in existence and has the most splendid foliage of all. The flowers range from bright pink to deep reddish purple and are freely produced in May. We can 110 too highly recommend this Rhododendron as we know it will give unqualified satisfaction. We have a splendid stock of nursery-grown plants, which we know will give unbounded satisfaction, and which we offer at the following prices, aceording to size; 18 inches, \$1.25 each, \$13 per doz.; 10 to 12 inches, 75 cts. eaeh, \$8 per doz.

\section{Dwarf Rhododendrons}

The dwarf Rhododendrons are extremely attractive and desirable beautiful both in foliage and flowers. The following varieties are perfectly hardy.

R. ferrugineum. Pink flowers, unspotted.

R. arbutifolium. Pale lavender flowers; dark foliage and red wand. R. punctatum. Pink flowers.

$$
\$ 1.50 \text { each, } \$ 15 \text { per doz. }
$$

\section{Rhododendron maximum IN CAR-LOAD LOTS}

Rhododendron maximum, commonly known as the Large-leaved Laurel, grows wild over a large extent of territory in this country, but usually under such conditions that it is impossible to successfully transplant it. I have found a source of supply where, although the plants are growing wild, they are in as good condition as if growing in a nursery, and of course can be supplied at one-fifth the cost of nursery-grown stock. The value of this Rhododendron for plantin in quantity in country places cannot be overestimated. It is perfectly hardy, thrives in sun, partial or full shade; extremcly showy when in bloom in July, the large heads of flowers being white or blushwhite, and on account of its bold evergreen foliage is extremely effective throughout the year. It is fine for naturalizing in the woods or the edge of the wood. It has been used in this way by the hundred ear-loads on the grounds of Mr. William Rockefeller, near Tarrytown, N. Y., and the head gardener there reports that the loss in transplanting did not average one plant to the ear-load. I have used great quantities on the grounds of my clicnts and practically have not lost a plant, and nothing I have used has been so immediately effective or satisfactory. Price on car-load lots furnished on applieation. For prices on smaller lots, see page 55.

\section{Bedding Rose, Gruss an Teplitz (CRIMSON HERMOSA)}

This, the reddest of all red Roses, is to the amateur, who has no grcenhouss, and depends on his garden for flowers, one of the most important varieties yet introduced. It is a rose for everybody, sueceeding under the most ordinary conditions. In color it is of the richest scarlet, shading to a velvety crimson as the flowers mature; in size it is larger than Hermosa, very fragrant, a free, strong grower, quite hardy, and a most profuse blcomer, the mass of color produeed being phenomenal; the foliage is extremely beautiful, all the younger growth being of a bronzy plum color We offer two sizes, all of which will flower freely this scason. Selected size, strong 2-year-old plants, 40 ets. each, \$4 per doz. First size, strong 1-year-old plants, 25 ets each, $\$ 2.50$ per doz., \$16 per 100 .

\section{Celastrus paniculata}

This is a comparatively new varicty of Bitterswcet from Japan. It is a beautiful vine of very rapid growth and fine foliage, and produces fruit much more freely than our native variety. The plants being male and female, one of each should be planted if fruit is desired. The fruit is orange-red in color and is extremely effective in the fall. 30 ets. each, $\$ 3$ per doz.

\section{Japanese Maples}

The Japanese Maples are of dwarf habit, rarely growing over 5 or 10 feet high, and are entirely hardy in the latitude of New York. The rich and glowing color of the leaves in spring and carly summer makes them the most beatiful oljects that can be planted on a lawn. A group of them during the months of May and Junc is a sight to te remembered. There are many varieties, all of which we can supply when desired; but the varieties offered bclow are the most beautiful and satisfactory of them all, and there is no place so small that should not have at least one of these exquisite dwarf trces. The stock that we offer is American growll, and is much superior to the cheap imported Japanese stock, which I consider almost worthless.

Acer Japonicum aureum. 24 inches, from pots... $\$ 250$ Each Doz. polymorphum. Green-leaved. Makes a fine specimen and colors beautifully in the fall.

100

Purple Cut-lcaved. 24 ins, from pots..................

Purple Cut-leaved. Large specimens.............. 400

Blood-leaved. 12 to 18 inches, bushy specimens......... 200

$\$ 200 \mathrm{C}$

Blood-leaved. Large specimens 400

Grèen Cut-lcaved. Makes a splendid specimen. 24 inches from pots.............. 250

Green Cut-leaved. Large spec. 500

Distinct and beautiful ...... 250

Filicifolium. Specimens ............... 500

\section{Kalmia latifolia}

Kalmia latifolia. commonly known as Mountain Laurel, is the most beautiful of all evergreen shrubs. Like the Rhododendron, it likes a light, loose soil that is free from lime, and will grow in either sun or shade but will flower more frecly in the sun. The flowers are wheel-shaped and set in close corymls on the end of the stems, pure white to pink, and appear in June in such profusion as to almost hide the foliage. It is only of late years that American planters have awakened to the beauty and value of this native shrub in all proper locations, though it has been highly esteemed and largely planted in Europe for many years. In numerous show places in England, the collection of "American plants," to which a visitor is conducted with pride, is made notable by our Mountain Laurel, which can so readily be established in proper locations anywhere in the. United States. Collected specimens are not so useful as nursery-grown plants, which transplant with entire safety. Fine nursery-grown plants, 25 ets. each, $\$ 2.50$ per doz.; 50 cts. each, \$5 per doz.; 75 cts. each, $\$ 8$ per doz.; \$1 each, \$10 per doz.; \$1.50, \$2 and \$3 each, according to size.

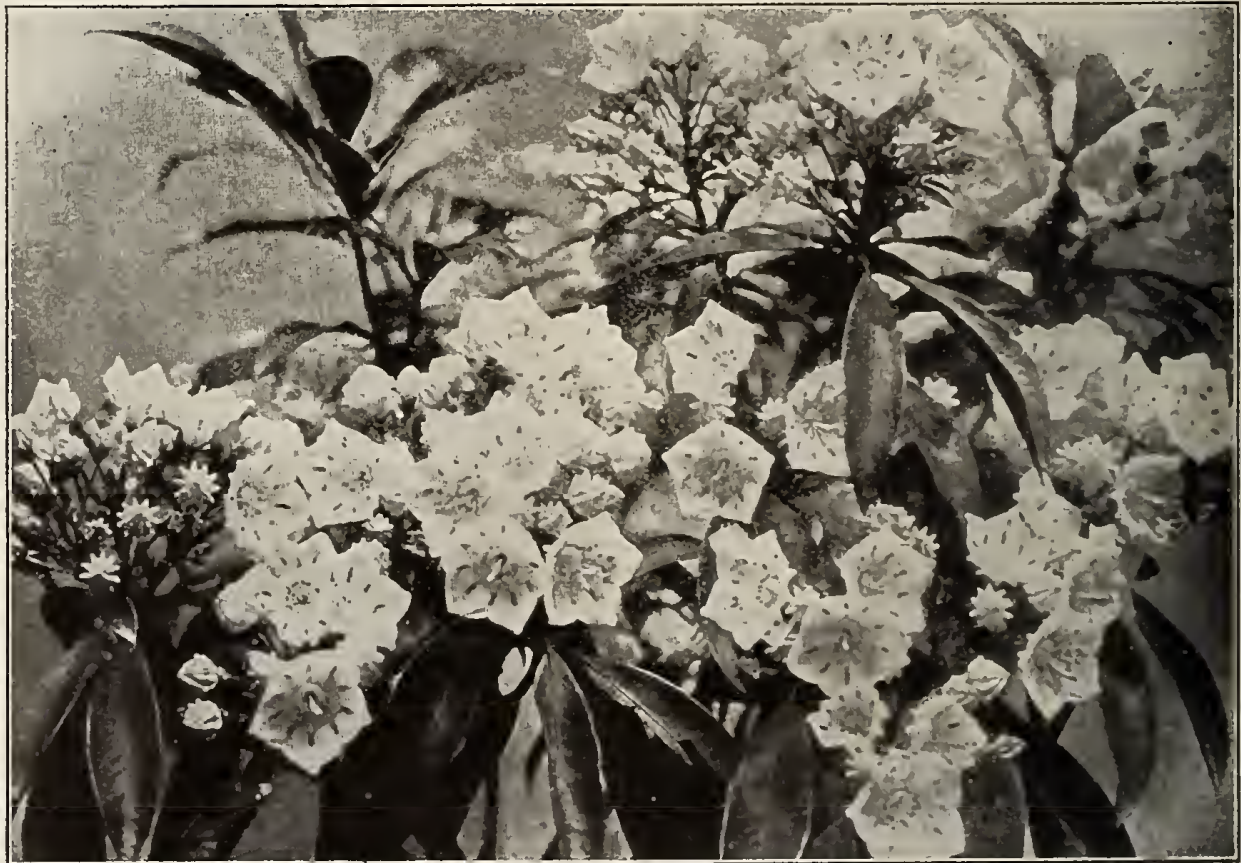

Kalmia latifolia 


\section{(1)}

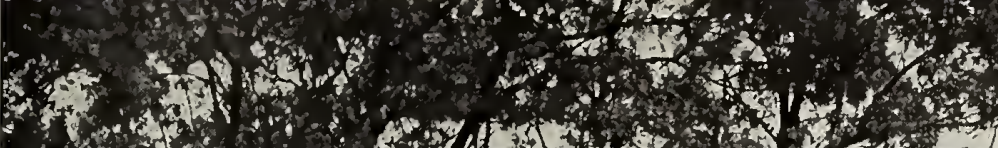

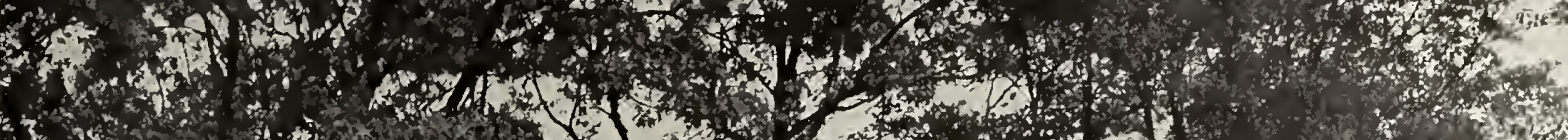

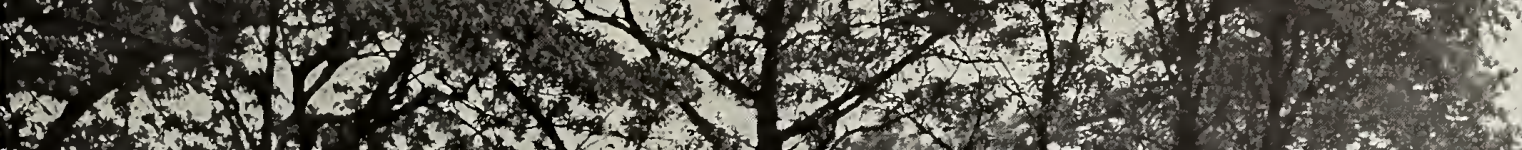

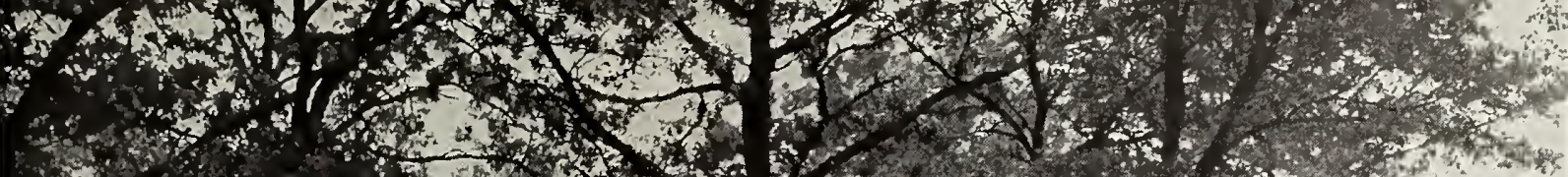
- 50 .

\section{3. \\ cos. \\ Hon $x$.}

He hor 19

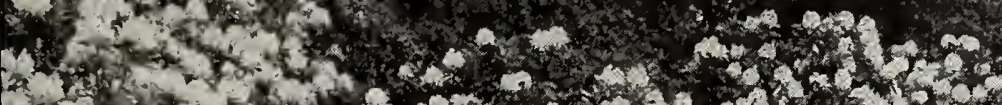

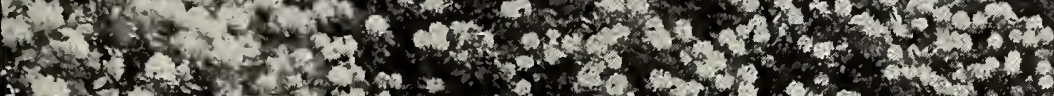

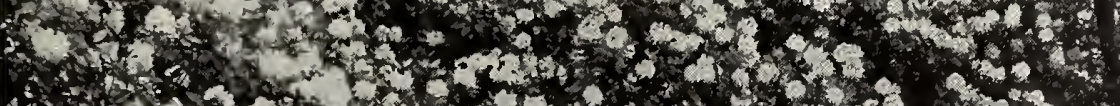

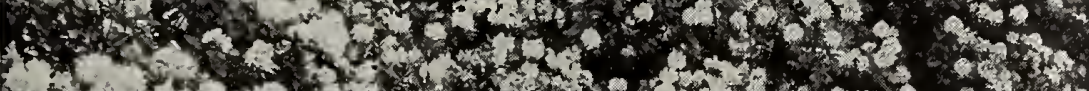

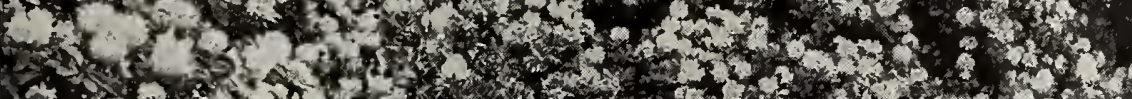

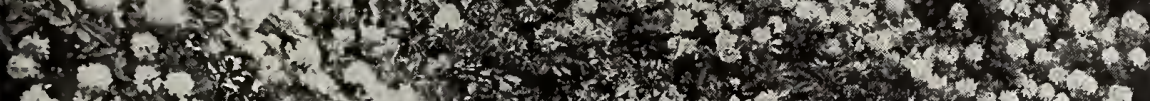
2.7.

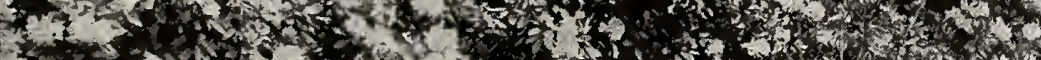

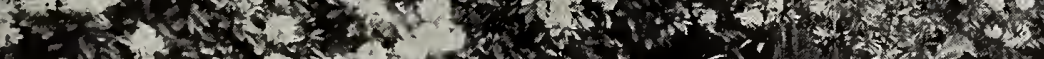

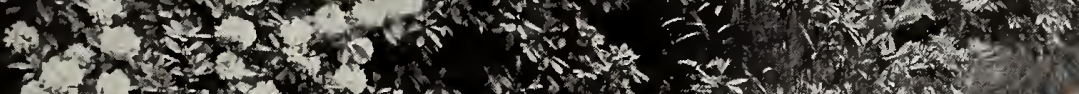

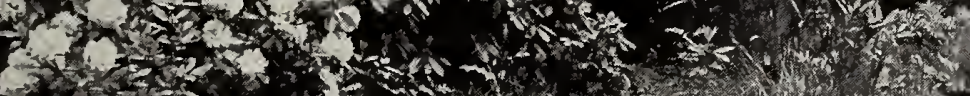

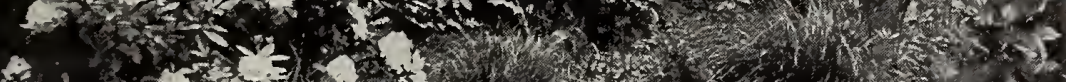

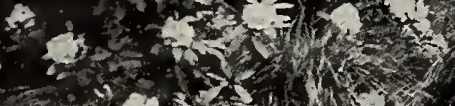

-anthos

$$
\text { W. }
$$

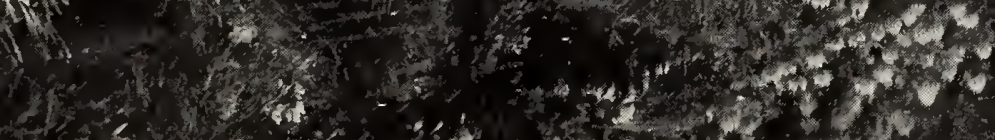

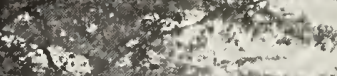
s.

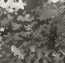

(a) $x^{2}+2$

$3+200$ ?

$-20 y=$

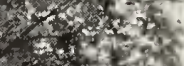

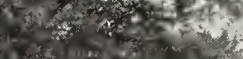




\section{Special Offer of Gladioli}

Gladioli sent postpaid by mail for 10 cts. per doz. and 75 ets. per 100 , in addition to priees quoted. Prices good until withdrawn. Delivery at any time from November until June 15.

For cutting, for the decoration of the house, or for any purpose for which cutflowers are used during the summer and fall montls, no flower ean be grown so satisfactorily as the Gladiolus. The spikes of flowers are large, slowy and very beautiful, and last a week in water after cutting. By planting at intervals from April 1 to Jume 15, they can be had in blossom from June 25 until frost. For cutting purposes they can be grown in the vegetable garden or any convenient place, and, as they can be planted very closely, a large quantity can be grown in a very small space. They are of the easiest culture, failure bcing practically impossible, and it can be safely estimated that the bull) will increase at least 50 per cent every season. The bulbs (an be wintered in any room or cellar that is free from frost. The bulbs offered below are strietly first-class, and are from the largest and best Gladiolus-growers in the world.

Seeding Gladioli. Supcrb quality; all colors

Per $100 \quad 1,000$

Mixed Gladioli. Best quality; all colors.

$\$ 225 \$ 1800$

Red and Scarlet Gladioli. Splcndid for massing in shrubberies 100

and borders.

White and Light Gladioli. A rhoice mixture made from all named

Gladioli; equal to what is generally sold at four times the price. . . $250 \quad 1800$ Pink Gladioli. Best quality

choicest named varieties....................\$0 75 \$4 50 \$40 00

Yellow and Orange Gladioli

Striped and Variegated.

New Gladioli Childsii. Best quality mixed............ $50 \quad 350$

$\begin{array}{lll}70 & 5 & 00 \\ 60 & 4 & 00\end{array}$

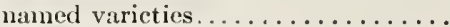

10 to 50 cts. each, $\$ 1$ to ....... 500

\section{MIXTURE}

This is a specially fine mixture, made up of over 100 fine named varieties, and includes also a good percentage of Childsii Hybrids. Just the stock for those who want only the very best that ean possibly be had. First size, $\$ 3$ per $100, \$ 25$ per 1,000 .

\section{Gardening Books and Papers}

It is hardly now necessary to call attention to that splendid magazine, Country Life in America, published by Doubleday, Page \& Co., of New York. This is hardly a gardening magazine, but considerable space is devoted to gardening matters and it is altogether the most beautiful and interesting magazine that we find on our library

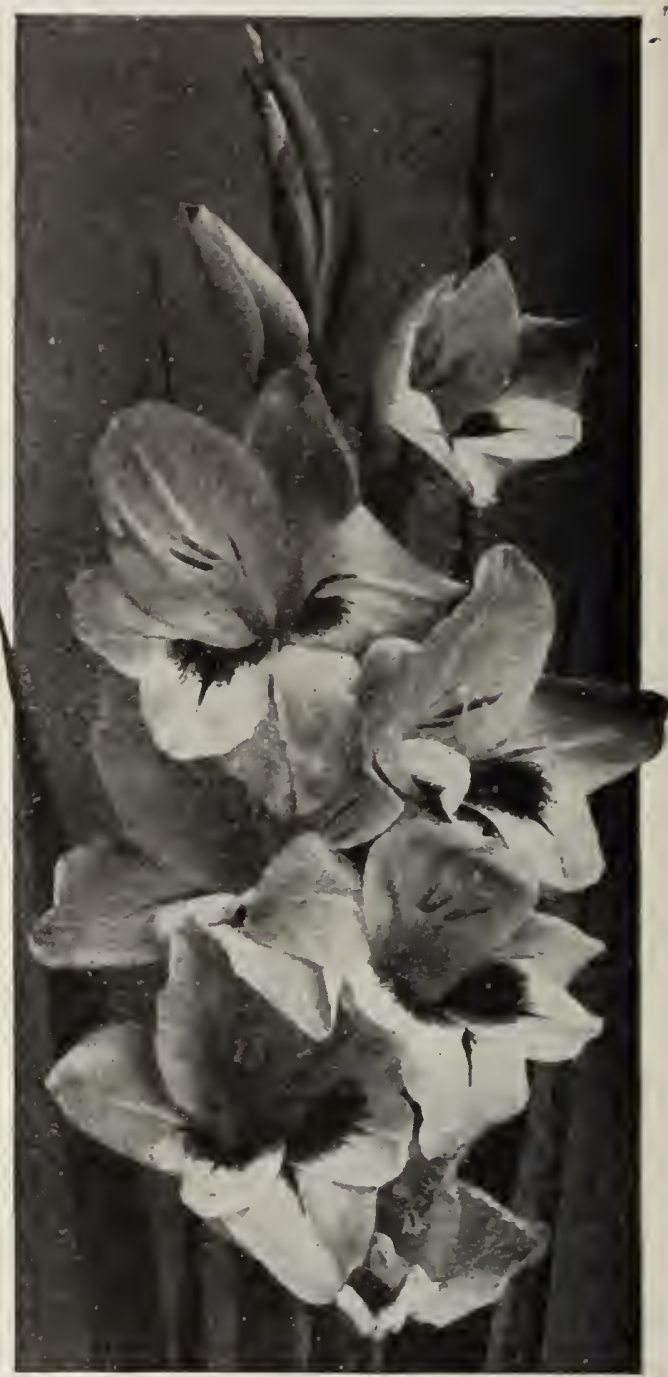

Gladioli

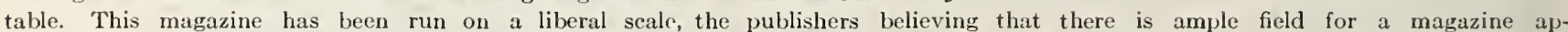

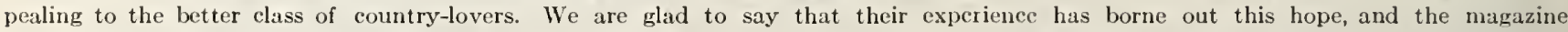

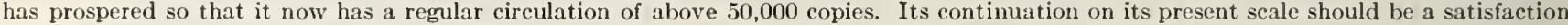
to every country-lover and every person connected with the country. The price is $\$ 4$ a year, and fully worth it.

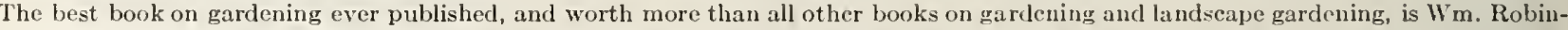

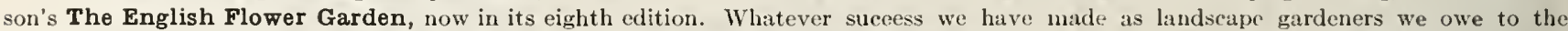

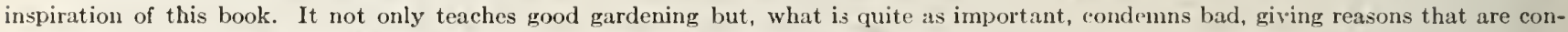

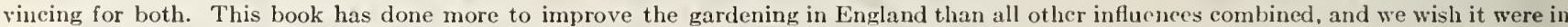

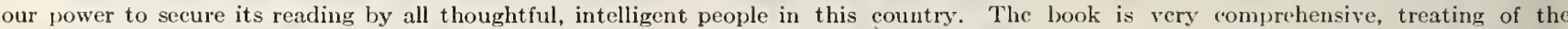

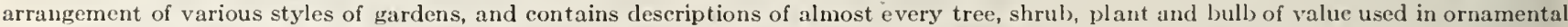

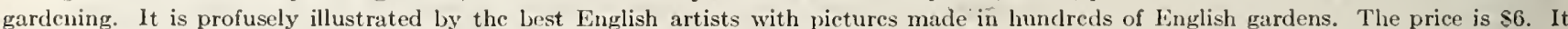
may be ordered from any bookseller, or we will forward it on receipt of the price.

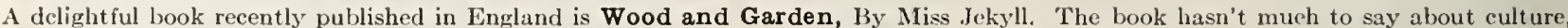

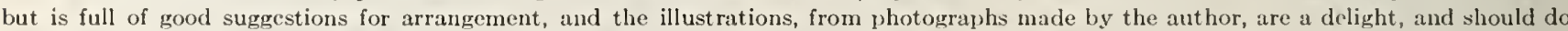

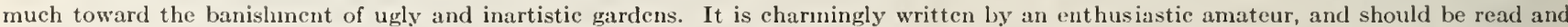

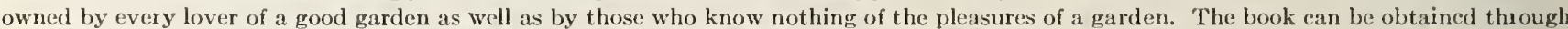

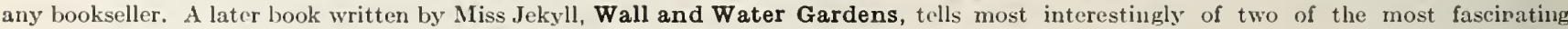

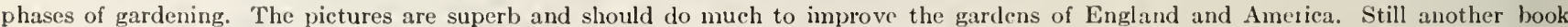

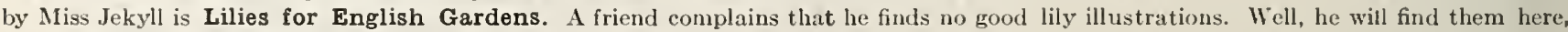
and the best and most exhaustive work on lilies yet written.

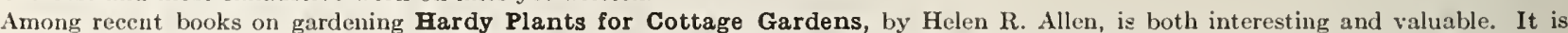

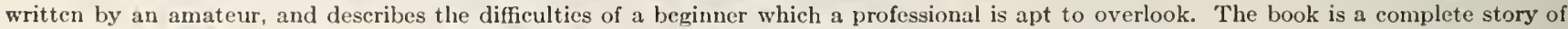

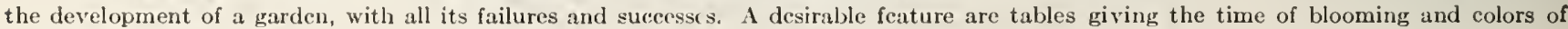
the most important hardy plants. These tables are arranged by montlis and colors. 


\section{Formation of Lawns from Seed}

The ground should be thoroughly drained and well prepared. The soil ought not to be too rich, as a rapid growth is not wanted in the grasses of a lawn, but the surface should be as much alike in quality as possible. After sowing, the ground should be rolled, in order to press the seed firmly into the soil. The proper time to sow grass seed depends, of course, upon the latitudes. In the central and eastern states, from september 15 to October 15 is the best time. Seed may also be sown in the spring, provided it is done early enough to secure a good, strong growth before the hot, dry weather of summer sets in. The sowing should be done when the ground is moist or before an expected rain, and a subsequent rolling is always advisable.

RoLLING.-As soon as the frost is out of the ground in the spring, the land should be gone over with a heavy roller. Winter frosts loosen the soil, and rolling is necessary to compress it again. If grass seed is to be sown, this should be done first and the rolling immediately afterward. Frequent rollings are recommended.

MowiNG.-All turf-forming grasses are improved both in vigor or root-growth and fineness of texture, by frequent mowings. It is impossible to say just how often the grass should be mown, as that depends upon the rate at which it grows. Too close cutting should be guarded against, however, especially during the hot summer months, when the roots require some top-growth to protect them from the burning sun. A good top-growth is also necessary to protect the roots from severe winter frosts. Mowing should, therefore, be discontinued in time to let the grass grow pretty long before winter sets in.

To Grass a BanK or Terrace.-For each square rod

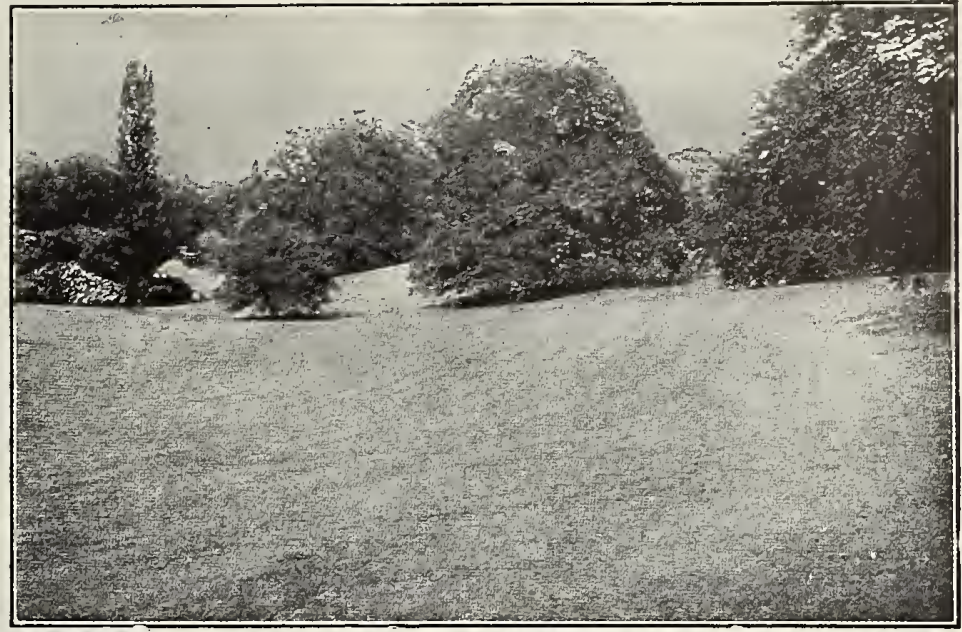

take a pound of lawn grass seed and mix it thoroughly with six cubic teet of good, dry garden loam. Place in a tub and add liquid manure diluted with about two-thirds of water, so as to bring the whole to the consistency of mortar. The slope must be made perfectly smooth and then well watered, after which the paste should be applied and made as even and as thin as possible.

\section{PRICES OF GRASS SEED}

We can supply the very best quality of Mixed Lawn Grass Seed for $\$ 3.50$ per bushel. This is exactly the same quality of seed that is usually sold for $\$ 5$ per bushel as Central Park Mixture, or under some other fancy name. Grass seed weighs only 14 pounds per bushel and can be shipped inexpcnsively by express. We do not supply less than one-half bushel. Special prices quoted for large quantities. Grass seed is sold by weight, 14 pounds for a bushel; but 14 pounds of clean grass seed will not fill a bushel. Grass seed can be sown advautageously in the fall, preferably in September. Prices: $1 / 2$ bushel, $\$ 1.85$; bushel, $\$ 3.50 ; 10$ bushels, $\$ 3.25$ per bushel; 25 bushels or over, $\$ 3$ per bushel. Small quantities shipped from here; large quantities from Cincinnati.

\section{Low Prices for Hydrangeas}

No more popular plant or shrub has ever been sent out than Hydrangea paniculata grandiflora, and we take great pleasure in offering in quantity. People who have only seen this Hydrangea grown singly as specimens have no conception of how beautiful and effective

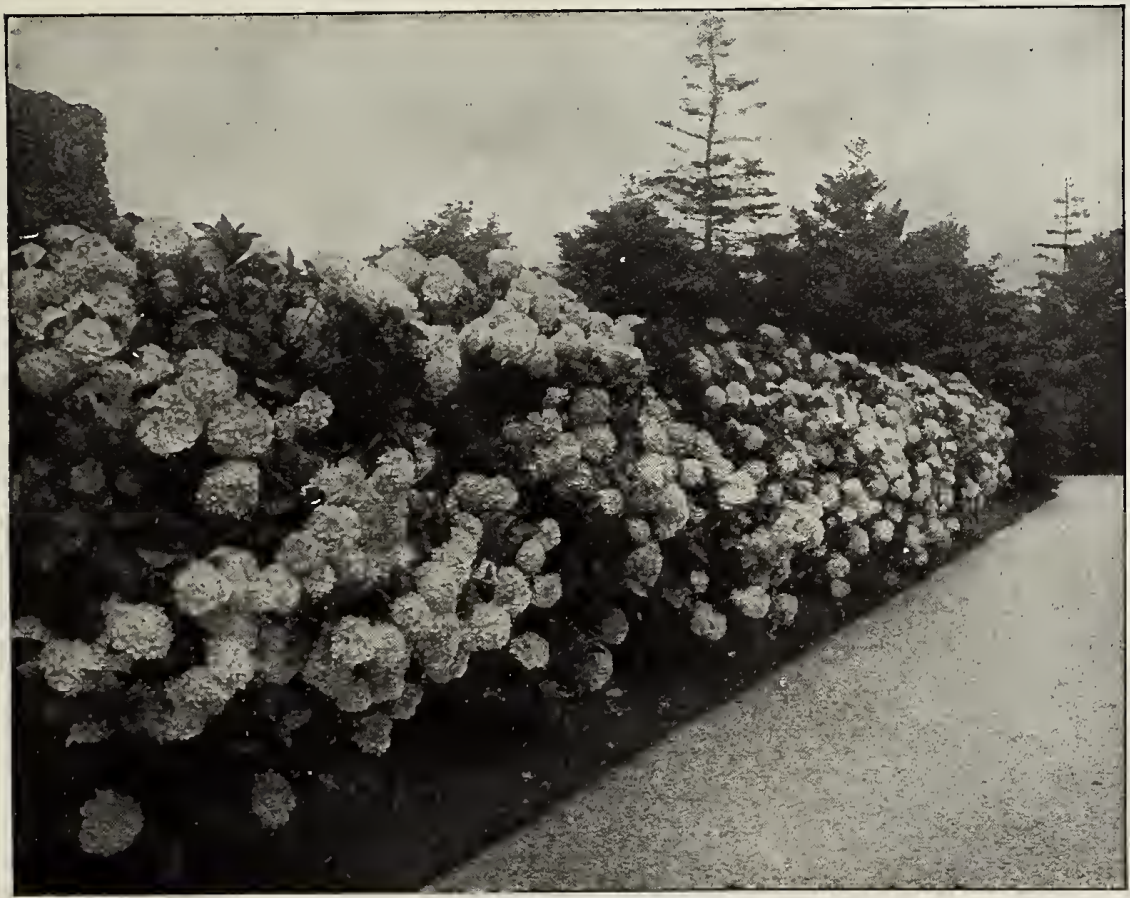

Border of Hydrangeas they are when planted in masses. They are planted in this way at Newport, R. I. which is famous for its fine gardens, and almost as famous for its Hydrangeas. These Hydrangeas can be planted in connection with other shrubbery or in isolated beds, in the same manner as cannas, caladiums or other strong-growing bedding plants. They are perfectly hardy, and, once planted, they are a permanent addition to the lawn or garden. When grown in beds or gro ups they should be planted about 2 feet a part, in very rich soil, which should be liberally enriched annually with rotten stable manure; and in the early spring, before they commence to grow, cut back so as to leave only two or three inches of the new growth of the previous season, and, if extremely large flowers are desired, cut out some of the weaker shoots after growth has commenced. Treated in this manner they will produce enormous panicles of flowers, and the beds will be a solid mass of bloom. They bloom profusely the same season planted. Try them. You will find them more than satisfactory. Prices good until stock is exhausted. Fall or spring delivery.

Hydrangea paniculata grandiflora-

18 to 24 inches.... $\$ 350 \$ 3^{25} 50 \quad 50 \$ 1200$

2 to $3 \mathrm{ft} \ldots \ldots \ldots \ldots 5 \quad 00 \quad 8 \quad 50 \quad 1500$

2 to $3 \mathrm{ft}$.; ex. hvy.. $600 \quad 1000 \quad 1800$

All of the above will bloom the first year, and are superior to the stock commonly retailed at 25 cts. to $\$ 1$ each.

It is suggested that when smaller quantities are wanted, two or three club together in ordering. For prices on smaller quantities, see Hardy Shrubs in our spring catalogue. 


\section{New Lilacs on Their Own Roots}

Of late years there has been a multitude of new varieties of Lilacs grown, and some of them have very great beauty; but, unfortunately, almost all the stock offercd, both in this country and Europe, has been budded on privet and is practically worthless, for Lilacs grown on this arc certain to die in a few years. Nurscrymen bud Lilacs on privet because they can produce a large stock quickly and inexpensively; but onc Lilac on its own roots is worth a score of budded plants.

Ten years ago we bought all the available stock of choice named Lilacs on their own roots in Europe, and since then we have been both growing and buying until we have a very large and fine stock, and the only stock of named Lilacs grown on their own roots in America. On account of their starting into growth so early in spring, Lilacs do best when planted in the fall.

Prices except where noted, $\$ 1.50$ each, $\$ 15$ per doz.

Alphonse Lavalle. Double; clear lilac.

Amethystina. Very dark reddish purple.

Bertha Dammann. Pure white; very large panicles of flowers; fine. \$2.

Cherles $\mathbf{X}$. Large, shining leaves and great trusses of reddish purple flowers. $50 \mathrm{cts}$.

Congo. Bright wallflower-red. 75 cts.

Dame Blanche. Double; white.

Geant des Batailles. Bright reddish lilac, in large trusses. Very brilliant and effective.

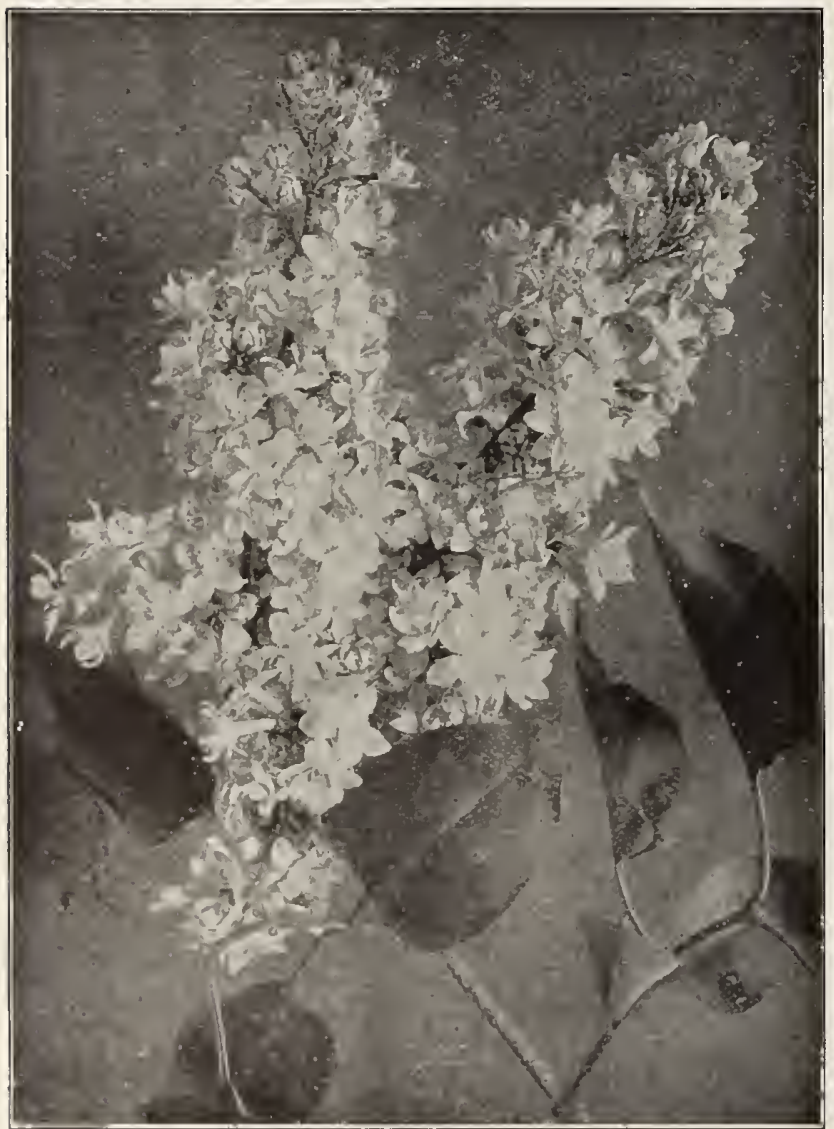

New Lilac, Marie Legraye

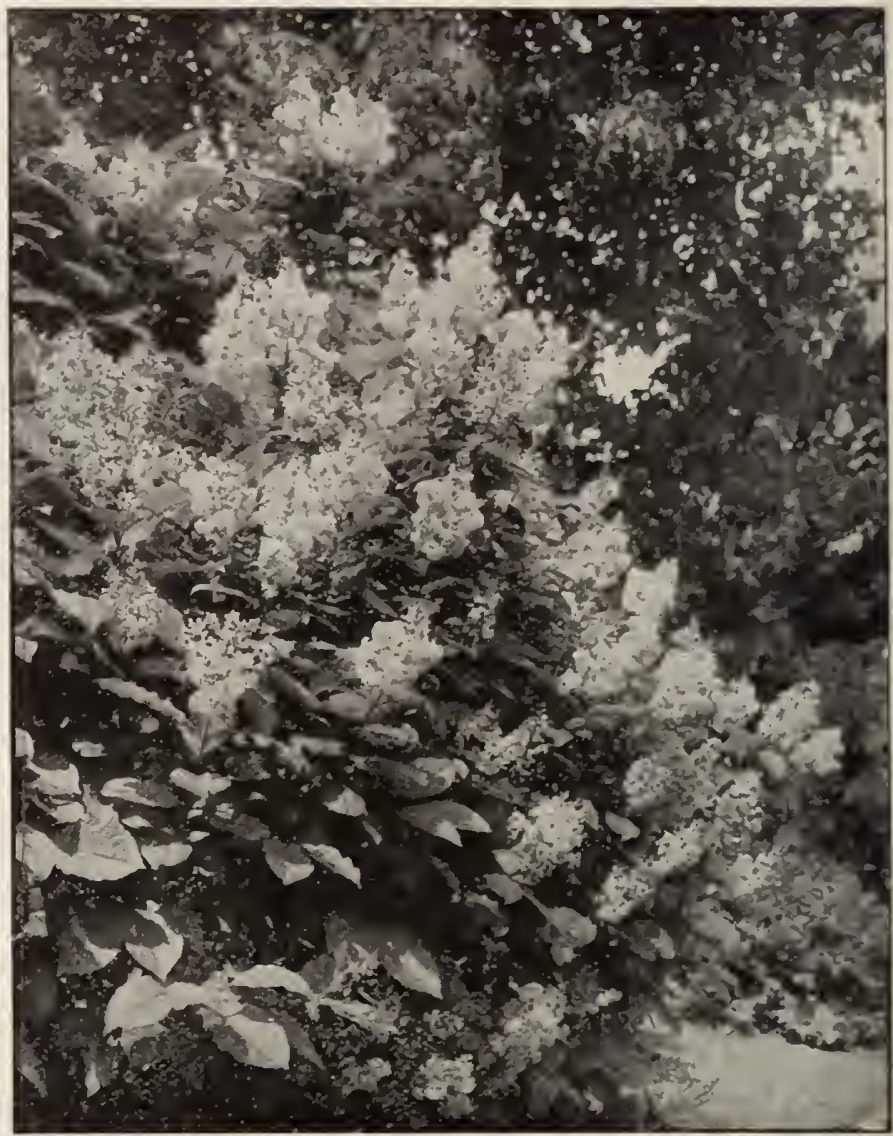

Syringa villosa

Jeanne d'Arc. Double; enormous spikes; pure white flowers, large and full; buds creamy white.

La Tour d'Auvergne. Double, purplish violet flowers borne in large trusses.

La Ville de Troyes. Large, purplish red flowers; fine.

Le Gaulois. Double; dark red. 50 cts.; extra-large plants. $\$ 1$.

Alba grandiflora. Very large flowers; pure white; borne in magnificent trusses. Extra fine in every way.

Madame Lemoine. Superb; double; white. \$1.

Marie Legraye. Large panicles of white flowers. The best whitc Lilac.

Michael Buchner. Dwarf plant; very double; pale lilac.

Negro. Very dark, violaceous purple.

President Carnot. Double; lilac tint, marked in center with white; extra-large, fine truss. $\$ 1$. $\$$,

President Grevy. Double; vinous violet.

Souvenir de Louis Spæth. Most distinct and beautiful variety; trusses immense; very large, compact florcts; deep purplish rerl. \$2.

Toussaint l'Ouverture. Dark crimson.

Villosa. A late-flowering species, blooming a month later than other varieties, with dcep pink flowers; extremely free-flowering and effective. Makes a large, splendid specimen. $50 \mathrm{cts}$.

Virginite. Pure white.

Viviand Morel. Extra-long spikes of large, double flowers of light bluish lilac, with whitc centers.

Wm. Robinson. Double; violaceous pink. The flower-trusses are extra large and the bush is vigorous and hardy. \$1.

\section{Extra-Large Lilacs}

We have on hand a few varieties of Lilacs in extra-large plants. Descriptions and pries of these on application. 


\section{HARDY AZALEAS}

We make a specialty of Hardy Azalcas, and have undoubtedly the largest collection and best stock in America. The Azalcas are the most beautiful and desirable flowering shrubs in eultivation and a collection should be included in every garden. Azalea mollis is especially valuable on account of its very showy bloom, hardiness and ease of culture, being quite as easy to grow as the commonest shrub. All Azalea. can be grown in partial shade, and the native varieties are fine for naturalizing. We wish to call especial attention to the value of our Native Azalcas. Therc is nothing in flowering shrubs more beautiful, and they are of the easiest culture, being much hardier than the imported varieties. For naturalizing, for the shrubbery or as individual specimens they are unsurpassed, and on large grounds they should be planted by the hundred.

\section{Azalea mollis}

We take special pleasure in offering an exceptionally nice lot of small Azalea mollis at a price inueh less than ever made before. The plants are hardy and in fine condition, and, with the exception of the small plants, are well set in bloom buds. Azalea mollis is of comparatively dwarf, bush-like habit, with light green leaves, which are somewhat larger than those of other Azaleas.

The flowers are as large as the Indian Azaleas usually seen in greenhouses, being $2 \frac{1}{2}$ to 3 inches in diameter, and appear in bunehes on the ends of the shoots. The colors are of various shades of yellow and red, and they expand about the middle of May.

We know of no other flowering shrub to equal them in attractiveness, and when massed in a large bed they create a particularly beautiful spot on the lawn. They are also vely effective when planted around the edges of rhododendron beds, as the dark green leaves of the Rhododendrons make a strong background for the bright colors of the Azaleas. They are also valuable for mixing in beds with the Azalea Pontica (Ghen: Azalea), as they bloon a little in advance of the others.

12 inches, fine plants

$\underset{\$ 075}{\text { Each }} \quad \stackrel{\$ 0 z}{\$ 80}$

12 to 18 inches, finc plasts.

$100 \quad 1100$

\section{Ghent Azaleas}

The following were imported from the best Azalea nurseries in Europe, and have since been grown in this country. They are exceptionally fine plants and well set with-bloom buds. The Ghent varieties are the finest of all Azaleas, and should be made a feature of every garden. The flowers, sweet-scented, are produced in the greatest profusion, and range in color from white to deep crimson through all shades of pink and yellow. Ghent Azaleas require a light soil, and should be kept well watered during a dry time.

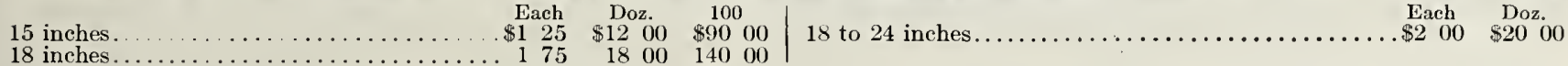

$1800 \quad 14000$

\section{Native and Other Azaleas}

Our native Azaleas are easily among the most beautiful flowering shrubs in the world, but hitherto it has been impossible to get good plants of them, as the stock generally offered is newly collected from the woods and very unsatisfactory. The following stock we have had specially grown for our customers, and it is strictly first-class and in splendid condition, and many of the plants are well set with bloom-buds.

AZALEA arborescens. (Native.) Splendid foliage throughout the summer. Large, white, sweet-scented flowers, borne in magnificent clusters all over the plant, making it a glorious sight when in full bloom. The latest Azalea to bloom. Fine plants. 18 inches, $75 \mathrm{c}$. each, $\$ 8$ per doz.

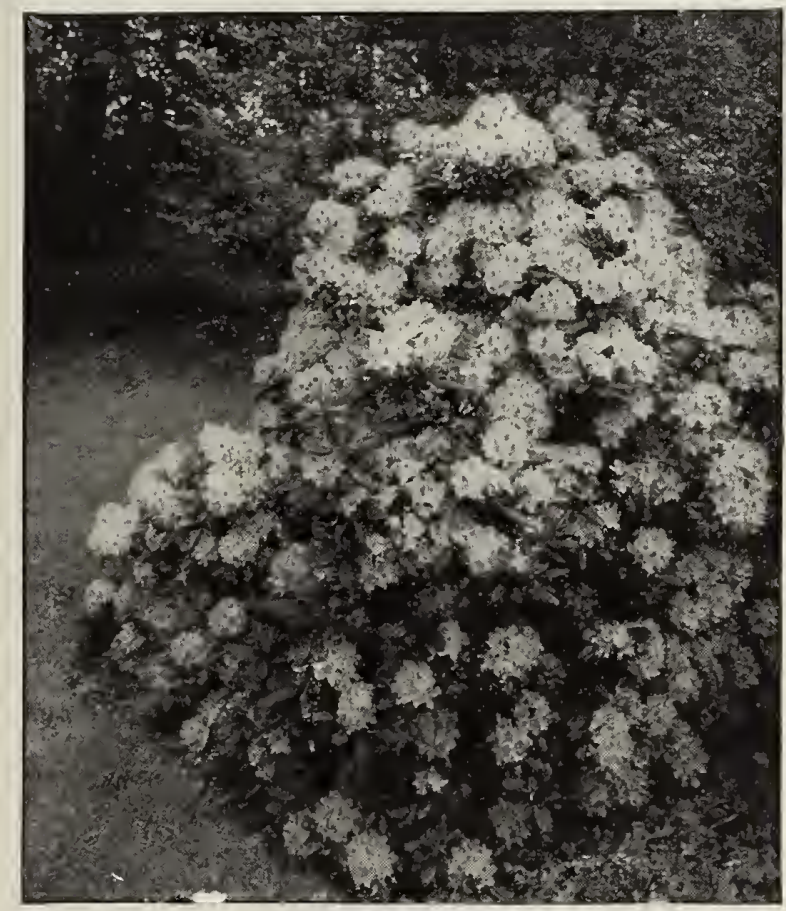

Rhododendrons
Azalea amcona. A dwarf, compact, evergreen variety, with rosy purple flowers; makes a beautiful specimen or can be used for an ornamental hedge. $\$ 1$ each, $\$ 11$ per doz.

Calendulacea. (Native.) Great Flame-colored Azalea. Flowers vary from deep crimson to bright sulphur-yellow; very showy. Finc plants, $\$ 1$ each, $\$ 10$ per doz.

Canescens. A lovely native variety with bright pink flowers. Very sweet-sccnted and the first to bloom. $\$ 1$ each, $\$ 10$ per doz.

Hinodegiri. This new Azalea is similar to A. amoena but hardier, and the flowers are much more brilliant. It makes a beautiful, dwarf, evergreen shrub. The flowers produced in the spring are a bright, fiery red. 10 to 12 inches, $\$ 1$ each, $\$ 11$ per doz.; 12 to 15 inches spread, $\$ 1.50$ each.

Nudiflora. (Native.) This is the Azalea found so plentiful in the Pennsylvania mountains and along the Allegheny River, and commonly known as the Wild Honeysuckle. Lovely pink flowers, produced in the greatest profusion. One of the most desirable shrubs in cultivation. Small plants, $50 \mathrm{cts}$ each, $\$ 5$ per doz.

Vaseyi. (Native.) This lovely Azalea has attracted a great deal of attention lately, especially in England, where it is highly prized. The flowers appear before the foliage in April in the greatest profusion and vary from blush to deep pink. This Azalea will in time grow to be 12 to 15 feet high. Strong plants, $\$ 1.50$ each, $\$ 16$ per doz.

Viscosa. (Native.) A dwarf variety with white flowers; nice plants, 12 to 18 inches, 75 ets. each, $\$ 8$ per doz.

\section{Rhododendrons}

We believe we are the largest importers of these splendid cvergreen shrubs in this country, and offer a very superior quality of plants. The varieties we supply are of unquestioned hardiness, and are certain to give first-class results when properly planted. They require a deep and light soil, and a bed for them should be dug out to the depth of 2 feet and filled in with light loamy soil mixed with one-half its bulk of turfy sods chopped up fine. No manure should be mixed in the soil, but an annual mulching of cow-manure is beneficial.

We will also quote very low prices on Rhododendrons by the 100 , to be imported to order; orders not to be received later than March 1.

Best Named Varieties. About 18 to 24 inches high, good bushy plants, set with bloom-buds, $\$ 1.50$ each, $\$ 16$ per doz., $\$ 100$ per 100 .

Best Named Varieties, Selected. 24 to 30 in., $\$ 2.50$ each, $\$ 27$ per doz. Specimens, $\$ 5, \$ 8, \$ 10, \$ 15, \$ 20$ and $\$ 25$ each, according to size Imported to order only 


\section{JAPANESE TREE PEONIES}

If you wish something to try your gardaning skill and patience, and to astonish your friends with, by all means plant a group of Japanese Tree Pconies. A lady who had seen them in bloom for the first time wrote: "Their wondrous beauty is electrifying; I am like the countryman who saw a guralie for the first time and said, "There ain't no such beast!" "Truly these Peonics are wonderful. Great, semi-

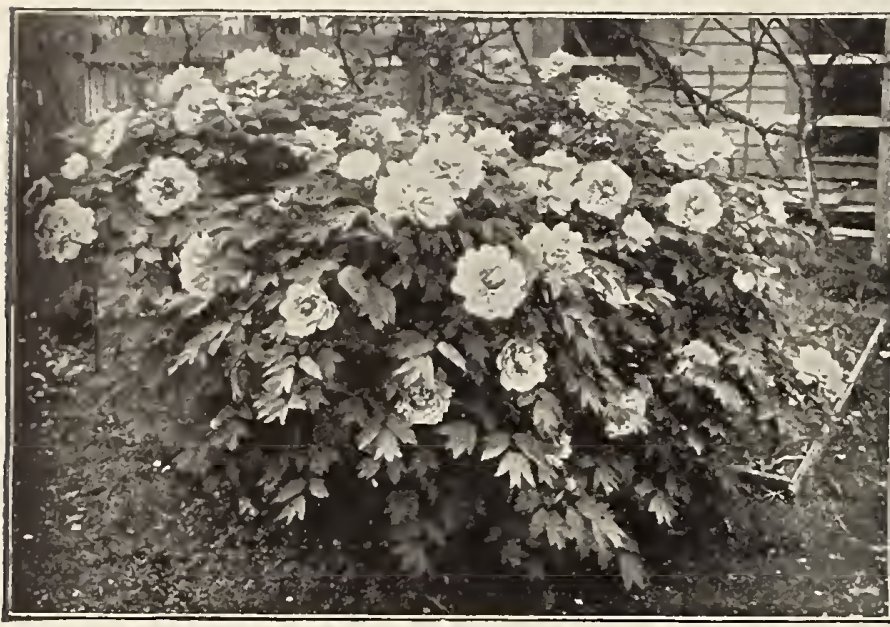

Tree Peonies double flowers almost as large as dinncr-plates, of the most exquisite coloring and texture. The petals arc like the finest Indis silks, and the colors range from pure white to bright crimson, including the sof test and loveliest shades of pink. But these glorious plants, like the Japs who raisc them, have some serious faults. They bloom so early that the buds and flowers must be protected from latc frosts; but their great drawback is that they arc grafted on a miserable purplc variety of little beauty but great vigor, and, unless watched almost night and day, the "suekers" from the root soon choke out the graft. It is said that this suckering can be discouraged by deep planting. The French growers graft on herbaceous Peonies, which do not sucker; but their varicties are in no way comparable with the Japanese. We are making a large importation of these Pconies in the winter. and orders will bo delivered early in the spring. $\$ 1.50$ each, $\$ 15$ per doz.

\section{COLORED DRAWINGS}

We have a set of colored drawings of the above Japanese Tree Pconies, which we will send for examination on receipt of 10 cents to cover mailing charges.

\section{PEONIES}

It gives us great pleasure to see the increasing popularity of Peonies, for there is nothing more deserving, and, when the merit and beauty of the newer varieties are known, every garden will contain a large collection. Like the Irishman's whiskcy, all varieties of Peonies are good, even the commonest old-fashioned sorts, but therc is no language to describe the glorious beauty of the finest of the newer varieties. In no other flower has there been such a marked improvement, and they actually surpass the rose in size, form and coloring, and their ease of culture and extreme hardiness are too well known to enlarge upon. Always having a keen appreciation of these supcrb flowers, we have for years collected all the varieties obtainable in the world, and now have the largest collection of varieties and the most cxtensive stock in America. Pconies planted in August or September will bloom the following season. Of many varieties offered in the following list, we can supply large, undivided clumps at from three to five times the prices quoted-prices depending upon how many salable plants the clumps would make if divided. By planting these undivided clumps a fine display of flowers can be had next season. Price-list of undivided clumps sent on application.

\section{Tree Peonies}

Best Named Varieties. 2 years old.......... Each $\begin{gathered}\text { Per doz. } \\ \$ 1400\end{gathered}$

Best Named Varieties. 3 years old............ $175 \quad 1800$

Queen Elizabeth. One of the best European yarietics.

Pink; large and full flowering. 2-years old........ $125 \quad 1400$

3 years old ........................... $200 \quad 2100$

Moutan. A fine old pink variety............. $100 \quad 1000$

Arborea. Not a very fine tree Peony, but one that

everybody ean grow. Large, showy, purple

flowers. Extra-strong plants............... 1 $50 \quad 1600$

Tree Peonies are for the enthusiast, for the man who is willing to take extra pains to have something rare and beautiful, and if he succeeds with these lovely things he is sure that he has flowers that will never become commonplace. Tree Peonies do not die to the ground every year, and eventually make quite large bushes.

\section{Single Peonies}

The merit and great beauty of Single Peonies has bee: largely overlooked. Planted in masses they are more effective than the double varieties, and fully equal them in the beauty of individual flowers. They come into bloom earlier and last longer.

Admiral Togo. (Jap.) Purplish rose center filled with bright yellow ligules; extra large and fine. Plant extremely vigorous and continues longer in bloom than any other variety. Three-year-old plants Each Per doz. produced as high as fifty flowers the past season...\$1 50

Astrø. Single; blush................... 50
Count Ito. (Japanese.) Rich purplish erimson Each Per doz. center filled with large buff and crimson ligules.

fine form, very showy and free flowcring........ \$1 $00 \quad \$ 1000$

Electra. Extra-large flower; light crimson, shading to pink........................... $50 \quad 500$

Formosa. Deep pink with showy yellow anthers; good. $50 \quad 500$

Gorgias. Extra large; pale pink, inner petals changing

to white, showy yellow anthers............ 75

Gubret». Rich carmine, bright yellow stamens; extra fine............................ 50

Ilion. Deep pink; extra large, in clusters......... 50

Ira. Light red; medium-sized flowers in clusters; very free.............................. 50

Juno. Purplish crimson with large bunch of yellow anthers; large and extra fine............. 75

Lacepede. Light crimson, yellow center.........6 60

La Fiance. Pure white variety of exquisite beauty;

extra-large flower.................. 150

Numilo. Dark crimson; dwarf and bushy; extra fine... 50

Vesticus. Bright pink................... 40

Seedling Singles. Shades of light pink......... 40 " " Shades of deep pink............ 40 Blush with yellow stamens and ligules .................6 60

" " Crimson........................... 50

" " White.................. 60 


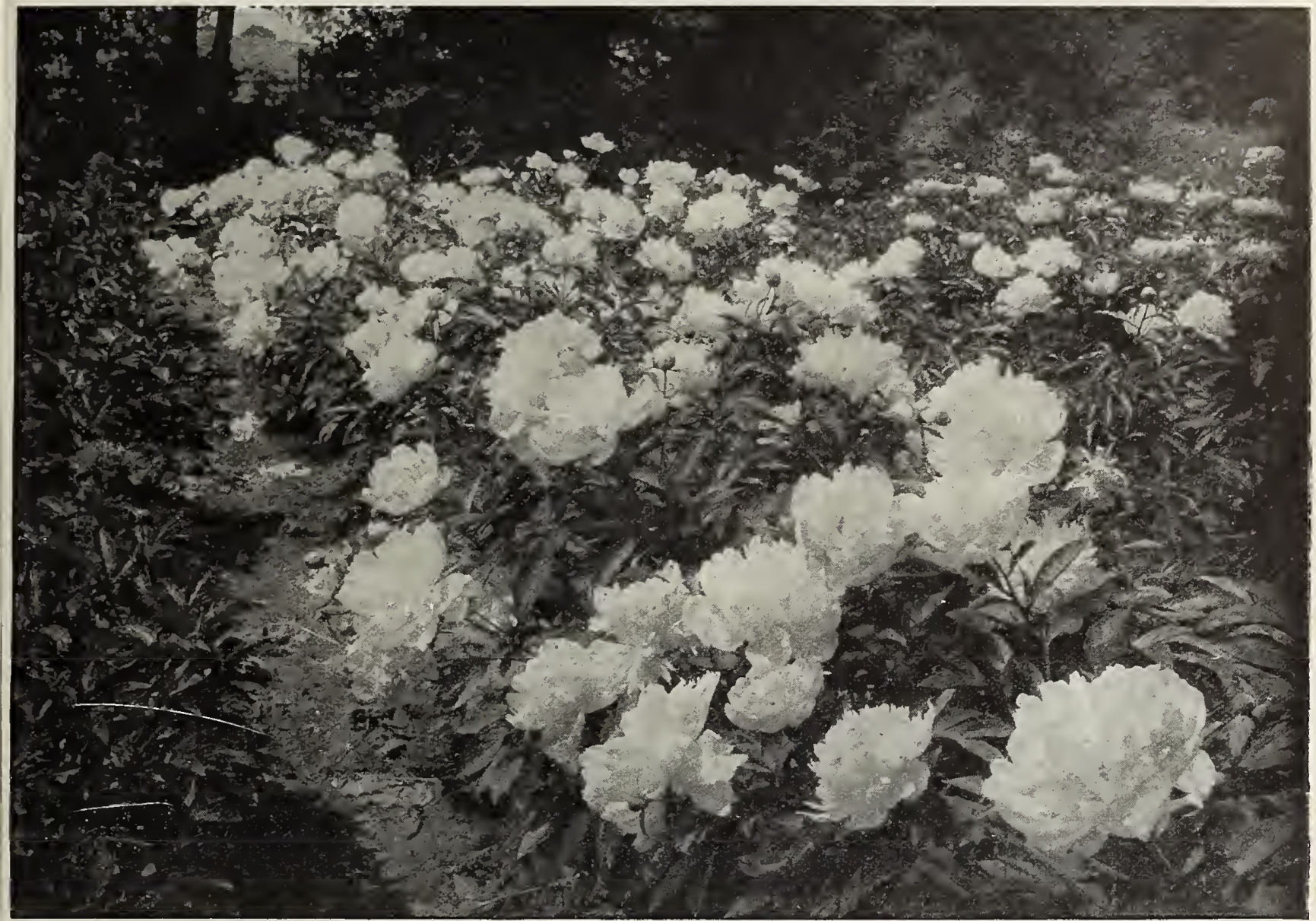

Avalanche Peonies

\section{Choice Named Double Peonies}

Achille. Delicate flesh-color, very fresh coloring .... $\$ 0 \quad 25 \quad \$ 250$

Agida. Brilliant red; very free-flowering.......... $35 \quad 350$

Ambrose Verschaffelt. Large, cup-shaped bloom; deep crimson-purple......................

Andre Lauries. Large, full flowers; anemone-shaped;

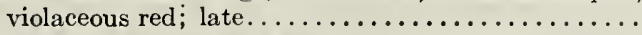
Albatre. Ivory-white; fine $\ldots \ldots \ldots \ldots \ldots \ldots \ldots \ldots$

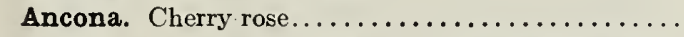

Asa Gray. Large, full flower; imbricated; beautiful form; carnation-salmon, powdcred with carmine-lilac.

One of the best.................... 150

Avalanche. Large flowers of perfect shape; milk-white, with a creamy center having a few carmine stripes; late and very free-flowering; splendid habit. A variety of great distinction and beauty............. 150

Augustin d'Hour. Large blooms; scarlet-purple, with silvery reflex ...................... 35

Baroness Schroeder. Ivory-white; a grand varjety .. 300

Beaute de Villecante. Large flowers; purplish pink and delicate flesh-color; extra ................

Belle Douaissienne. Flesh and chamois; very lovely..

Boule de Neige. Large, cup-shaped flower of perfect shape; white, lightly sulphured, center bordered with bright carmine; extra fine................. 150

Charlemagne. Large flower; creamy white, shaded

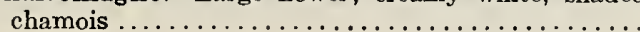
50
Claire Duboıs. Large, globular flowers; very full; most beautiful pink; glossy reflex. Very fine.........\$2 00

Comte d'Osmant. White, with sulphurish center. A fine large flower.................

Couronne d'Or (Golden Crown). Large, imbricated white flower, yellow reflex, with stripes of carmine and golden stamens; extra finc. One of the very best lates, and fine for cutting.

Canari. Guard petals fleshy white, yellow center;

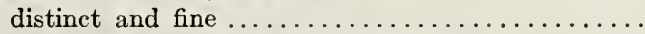

Crimson Queen. Splendid, rich crimson .......... Delachei. Large, cup-shaped flower; deep amaranth; carried on long stems.

Dorchester. Cream-color, tinged pink; very double;

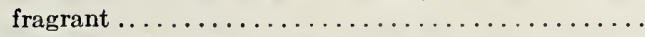

Doyenne d'Enghien. Rose-violet, very dark, prettily

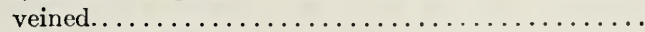

Duchesse de Nemours. (Calot.) Very bcautiful, cupshaped flower; sulphur-white, with greenish reflex;

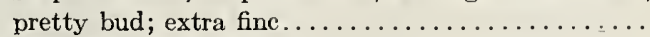

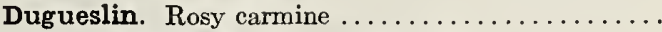

Duke of Wellington. Sulphury white.

Edouard Andre. Large, glotular flower; deep crimsonred, shaded black, with metallie reflex; stamens goldyellow, magnificent coloring, producing grand effect. $100 \quad 1000$

Doz.

\section{5}

$60 \$ 600$

$50 \quad 500$

$50 \quad 500$

$35 \quad 350$

75

35

350

$35 \quad 350$

$40 \quad 400$

$30 \quad 300$

Emily Hoste. Pale creamy white............. $50 \quad 500$ 
CHOICE NAMED PEONIES, continued

Edulis superba. Very large flowers of perfect shape Each Doz. leaut iful, brilliant, tinted violet, mixed with whitish limules; silvery reflex.

Eugene Verdier. Larke, ('up-shaped flower; flesh-pink, shaded yellow and salnon; extra fine.......... 150

Faust. Anemone-flowered; guard petals soft lilae, center flesh, sliaded chamois.

Felix Crousse. Inormous flower; brilliant red; extra.

Festiva. Dwarf; pure white, enter ('irmine-spotted. the same as Festiva naximal but dwarf; large flower; excellent

Festiva maxima. Very lare, pure white flowers, with sone blood-red stains in center: tall stalks: beautiful foliage, and very free-flowering. One of the very best white Peonies in cultivation. (Sec illustration, p. 23.)

Floral Treasure. Soft rose, ligules buff, with tufts of rose petals in center; earried on long stems; distinet and fine; fragrant $\ldots \ldots \ldots \ldots \ldots \ldots \ldots \ldots \ldots . . . . .$.

Formosa. Pretty eonvex flower; yellowish white,

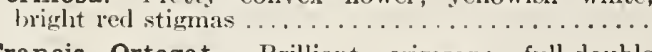

Francis Ortegat. Brilliant crimson; full-double

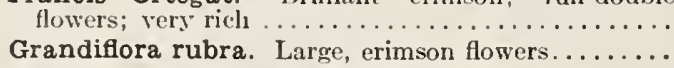

Golden Harvest. Nearest approaeh to yellow .......

Goliath. Enormous, rose-pink flower................ 200

Grandiflora carnea. Flesh, with elear lilae ....... 25

Germaine Bigot. Large flowers; glossy flesh-eolor, shaded salmon-tea; of a delieate freshness; very beautiful

Hon. B. F. Jones. Semi-double, outer petals white, renter filled with yellow stamens resombling a waterlilv: very lovely.

Humei. A splendid old sort, with extra-Each Doz. large decp rose-pink flowers; one of the latest to bloom.

Jeanne d'Arc. Large flowers of soft rose, sulphur-white, and lively rose, center stained carmine, lovely, fresh coloring

Lady Leonora Bramwell. Silvery rose; fragrant.

Lohengrin. Soft pink, eenter pink....

Luteana. Soft pink, center pink and salmon-yellow

La Tulipe. Very large, globular flower, rosy white eenter, outside of the flower lively carmine, enter striped deep carmine; extra fine.

L'Eclatante. Carmine; very beautiful.

Livingston. Large flowers; soft pink, washed with whitc; ceuter touched ("armine; lovely

Louis Van Houtte. Large flower of lively violet-red; very brilliaut; a very beautiful varicty

Lutea variegata. Fleshy white, shaded yellow:

La Vestale. Beautiful, globular flower; sulphur-white

L'Indispensable. Rosy pink, blush center; large and very fine............

Madame Bruan. Brilliant rosy flesh, center creany white, shaded yellow, fading to pure white; large flowers; extra finc

$\$ 0 \quad 30 \$ 3 \quad 00$

\author{
50
}

$40-400$

$50 \quad 500$

$40 \quad 400$

75

35

75

30

35

75

60 1

Madame Bucquet. Velvety black-amaranth: coloring extrenely dark and rich. radame Caste. Large, blush guard petals, lemon center

Madame Crousse. White, tinted pink, conter carnine; bordered very lovely.

Madame de Galhan. Soft glossy fleshpink

Madame Furtardo. Guard petals bright, violaccous pink, center salmonpink

Marguerite Gerard. Lovely light pink; one of the most exquisitely beautiful Peonics in cultivation.

1000 $00 \quad 10 \quad 00$ $50 \quad 500$

$35 \quad 350$ $100 \quad 1000$ 30 300 1.50

30300

$50 \quad 500$

$20 \quad 200$
Marie. White, washed with chamis: very late varicty. 8075

Marie Crousse. Very light salnın-rose, edged pure

white; extra fine...........................

ing; ivory-white ....................

Meissonier. Large flower; brilliant purple-amaranth. 40

Milton Hill. Large flower; fresh pink. with oceasional

markings of carmine; extra fine.............. \pm 00

Mirielle. Late; milky white; distinet and fine ....... $100 \quad 1000$

Mme. Calot. Large flower; very doulsle; carnatinn-

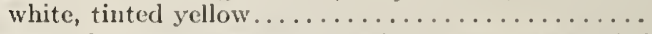

Mme. Chaumy. Large flowers in eluster; rose-slateded

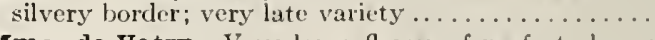

Mme. de Vatry. Very large flower of perforet shape; color clear carnation, sulphur-white centry" with carmine stripes; extra-fine variety ............. 100

500 Mme. de Verneville. Very pretty anomone flower, very full; collar of lange petals, those of the center very close; carnation-white and sulplur, somwtimes earmine; $\operatorname{extra} . . \ldots \ldots \ldots \ldots \ldots \ldots \ldots \ldots$

Mme. Jules Elie. Glistening pink, edged silver-rose;

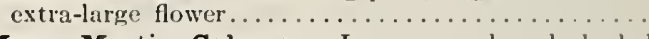

Mons. Martin Cahuzac. Large; purple-red shaded black-maroon; the darkest variety in cultivation;

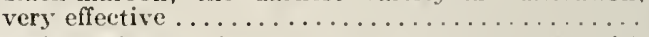

250 Ne Plus Ultra. Violet-rose, center maure-rose with

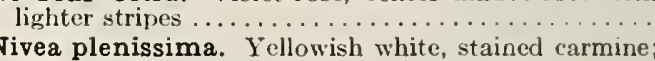
dwarf plant.

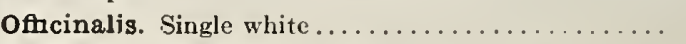

Officinalis mutabilis alba (Old Double White). Blush-white; early flowering.$\ldots \ldots \ldots \ldots \ldots \ldots$.

50500

4040 )

$50 \quad 500$

$50 \quad 500$ 400

30300

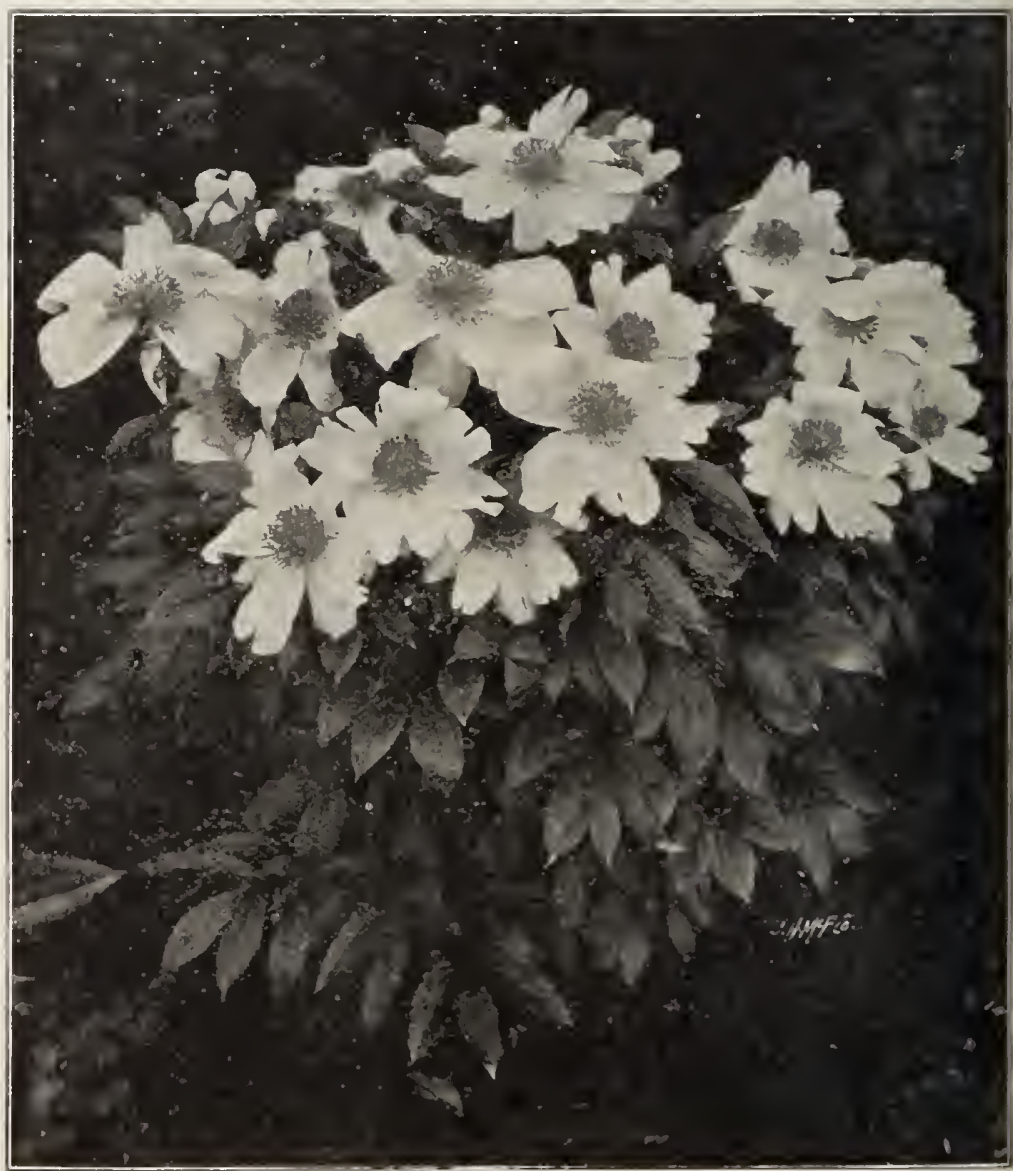

Single Peonies 


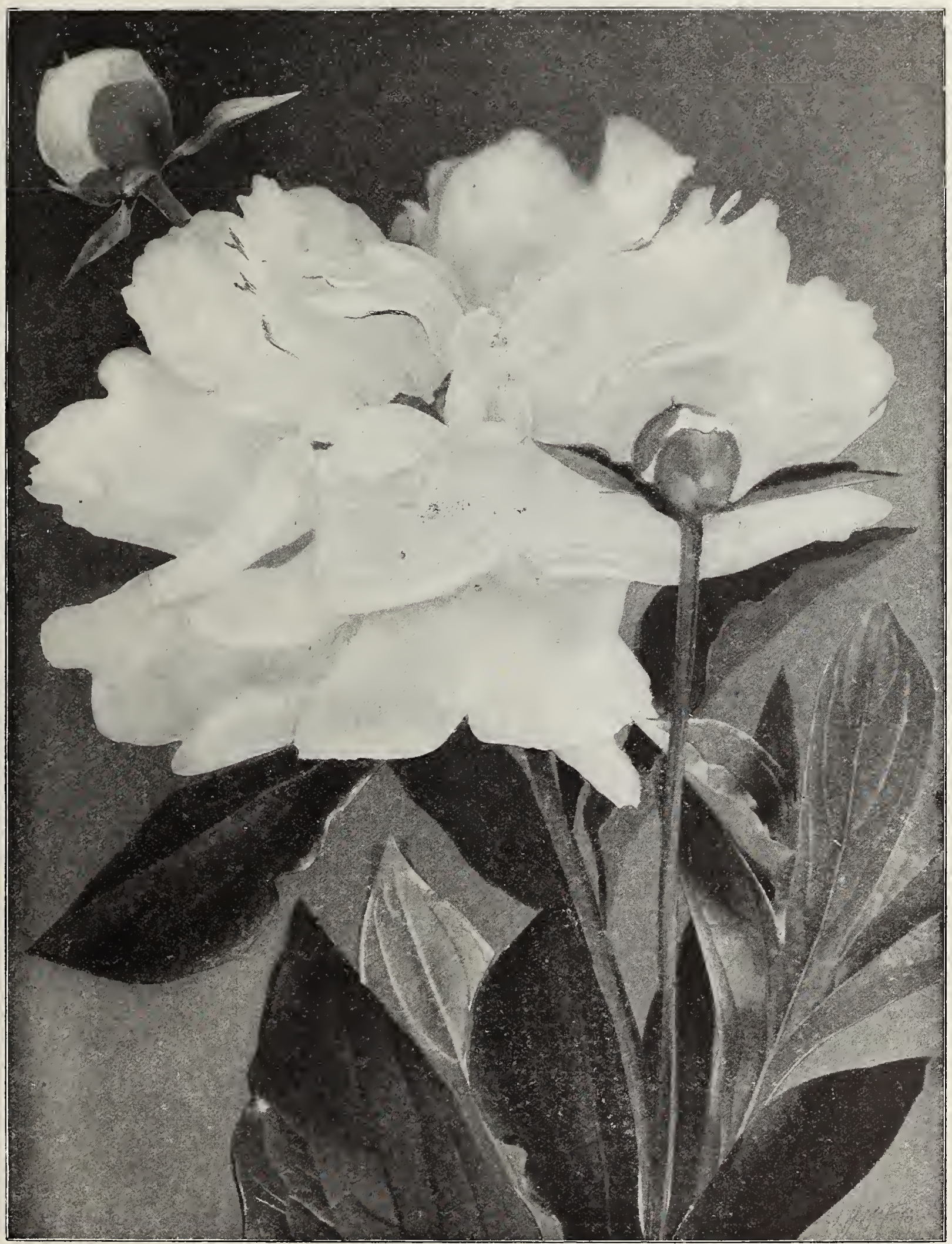

PEONIA FESTIVA MAXIMA

One of the finest white Peonies in cultivation. See deanription. page 22 (23) 
CHOICE NAMED PEONIES, continued

Officinalis rosea (Old Double Rose). Each Doz. Rich, bright, shining rose; very early. .\$0 $35 \$ 3 \quad \$ 0$ Old Double Crimson. Very effective when planted in masses; one of the earliest to bloom........ \$20 per 100 .
Perfection. (Richardson.) Light pink, fading to flesh; fine and fragrant.... 125

clusters; clear carmined purple, central petals very narrow, clear carmine striped white, golden extremities..... 150

Pottsi plena. Fine crimson-purple .... 35

Preciosa nova. Yellowish white, washed with bright carmine

President Roosevelt. Double flower dark red

Prince de Salm Dyck. Lovely lilae, chamois center

Princess Galitzin. Soft carnation, very narrow ecnter; petals of sulphur-yellow; fulc . ........................ tiful rose-color; very fragrant. ........

Queen Victoria. White, suffused with pink d............................. soft carnation-pink; very fresh color; fine.

Rubra superba. (Richardson.) Grand, globe-shaped flower; purplish crimson; very late. One of the finest reds in eultivation

Rubra triumphans. Crimson-purple. .

Sara Bernhardt. Large flowers of fine effect; corolla of large petals, lively violet-1 ose, center salmon.

Seedlings. All colors mixed.

Solfaterre. Collar of large, pure white petals, those of the center narrow and sulphur-yellow. One of the best

Souvenir de l'Exposition du Mans. Large flower; beautiful, lively violetred, with brilliant silvery reflex; extra

fine.

Clear cherry-1 ose; very brilliant. . . . .
Thorbecki. Very large flower; beautif ul silvery rose

Tenuifolia. Same as following variety, but with beautiful single flowers....

Tenuifolia flore pleno. Deeply eut, fringe-like foliage; flowers bright scarlet-crimson: rare and fine.

Triomphe de l'Exposition de Iille. Large, imbricated flower; soft carnation-pink, with white reflex, carmine center; very fresh coloring. One of

the best.............................

Triumphans Gandavensis Large flower; pinkish white, shaded chamois;

Variegata. A Japanese variety with curiously twisted and fringed petals; the flowers are small, striped and blotehed with earminc. Attraets much attention... $\$ 0 \quad 50 \quad \$ 500$

Victoire de l'Alma. Large flower of pcrfect form; purplish violet-scarlet, silvery reflex; extra.

victoire Leman. Fresh pink eollar, sulphur center. boldered carmine; very pretty flower...............

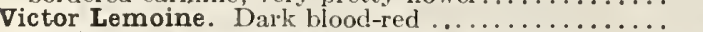

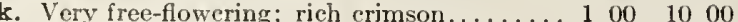

Zoe Calot. Very large flower, globular, very full; soft pink, shaded lilac; extra fine..................

$50 \quad 500$

\section{Kelway Peonies}

Kelway \& Son are the most famous of the English Peony-growers. The following is a seleetion of their best varieties:

Arimus. Purple-erimsoll, showing golden anthers.

Baroness Schroeder. Flcsh-white. Grandest Pcony kuowu.

First-class certificate, R. B. S

Cyclops. Purple-crimson. First-class certificate, R. B. $\dot{S}$

Duke of Cambridge. A very handsome bright erimson flower;

a superb variety; the very best of its color..... \$ 8 per doz...

Duke of Devonshire. A large varicty of deep rose-color,

with large outer guard petals. Award of Merit, R. H.S... 100

Guboles. Light pink, with broad guard petals

Lord Roseberry. Crimson; very fine.

Each

075

300

30

75

100
35

150

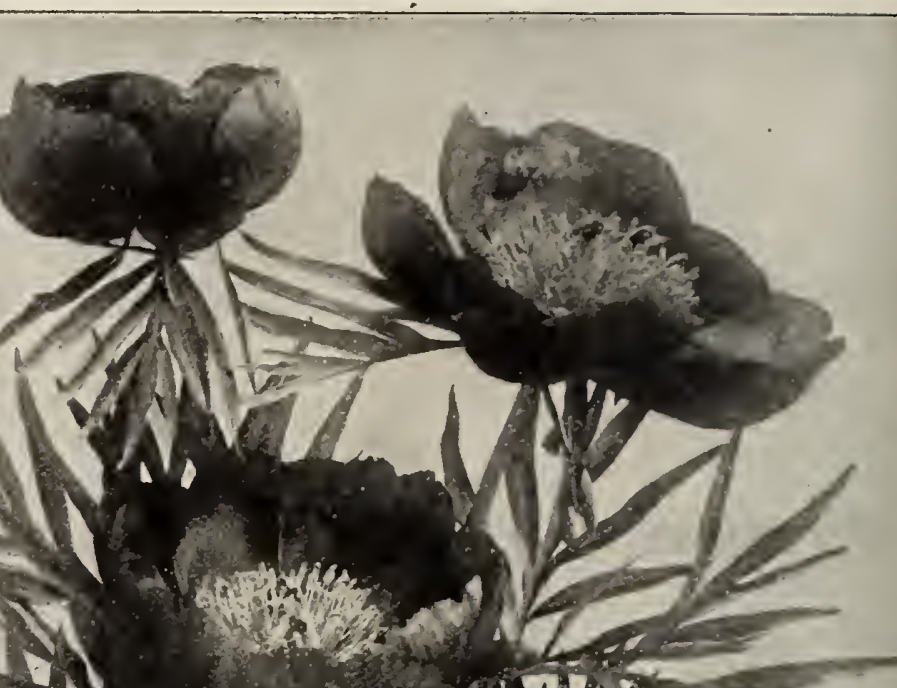

.

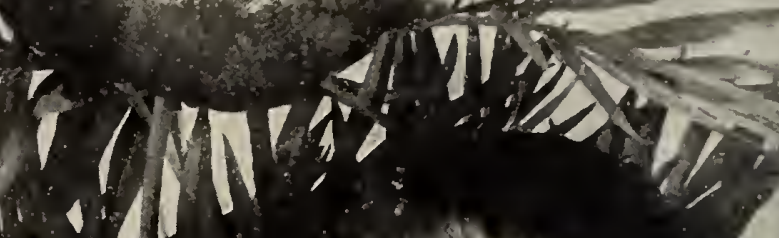
.

Pæonia tenuifolia

Erch

Lottie Collins. Decp purple; early. Award of Merit, R. H. S.\$0 50 Miss Brice. Rose guard petals, yellow and rose petaloids, rose tuft. First-class certificate, R. H. S. ..................... 100 Moonlight. Large; whitc; tufted. Award of Merit, R. H.S. 200 Mr. Manning. Glowing crimson. Certificate of Merit, R. B.S. 75 Olivia. A lovely flower, with broad white guard petals and a

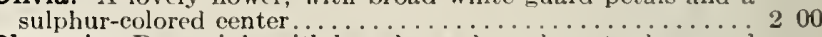
Phormis. Deep pink, with broad guard petals; extra large and very double; first-class variety. ...........\$8 per cloz. . 75

Prince George. Fine purple. First-class certificate, R. B. S.. 100 Sir T. J. Lipton. Large flower, with golden stanens appearing in the center of bright rosy crimson petals. "A huge, double, bright rosy carmine flower of grcat merit."- Gardening 200 vittata. Deep pink guard petals, center filled with bright pink and salmon ligules ............\$2.50 per doz..

\section{Mixed Peonies}

We have a few hundred Peonies from which the labels are lost. We supply these at 20 ets. each, $\$ 2$ per doz., $\$ 14$ per 100.

Special Offer of Named Peonies. We have a good many named varieties, in strong roots, a few of each, not enough of a kind to catalogue. They are worth from $50 \mathrm{c}$. to $\$ 1.50$ each. We will supply these in a good assortment, our selection, labeled, at $40 \mathrm{cts}$. each, $\$ 4$ per doz., \$25 per 100. 


\section{German Iris}

In the Iris family the German varieties rank second in importance, the magnificent Japanese Iris bcing first, of course. They bloom profuscly early in May, are of the greatest hardiness and easiest culture, and should be freely planted in every garden. These Irises are the "Flags" of the oldfashioned gardens. They are most effective when used as edging for a shrubbery or garden border. There are no pure white varieties. Named Varieties, 15 cts. each, $\$ 1.25$ per doz., $\$ 8$ per 100 , unless otherwise noted.

Mixed Varieties. 10 cts. each, 75 cts. per doz., $\$ 5$ per 100 .

Albatross. Standards are white, shaded with palest blue; falls white, tipped purple; a very lovely variety.

Canary Bird. Pale yellow; lovely. Charlotte Patti. Standards lemon-yellow, falls same, veined reddish brown; dwarf.

Dalmatica. Delicate lavender. Tall, vigorous plant with very large flowers; one of the finest of all Irises. 25c. each, $\$ 2.50$ per doz.

Dalmatica, "Khedive." Pale blue. 25 cts. each, $\$ 2.50$ per doz.

Darius. Large; yellow and lilac. large flowers.

Donna Maria. White. tinged lilac.

Florentina alba. Silvery white; early.

Fragrans. Lovely white, edged with violet.

Gluck. Standards white, falls purple. Extra-large flowers for cutting

President Thiers. Bronze-purple standards, dark purple falls. A most distinct, richly colored flower.

Her Majesty. Lovely rose-pink. A variety of great distinction and beauty. 35 cts. eaci.

Honorable. Yellow, talls brownish maroon.

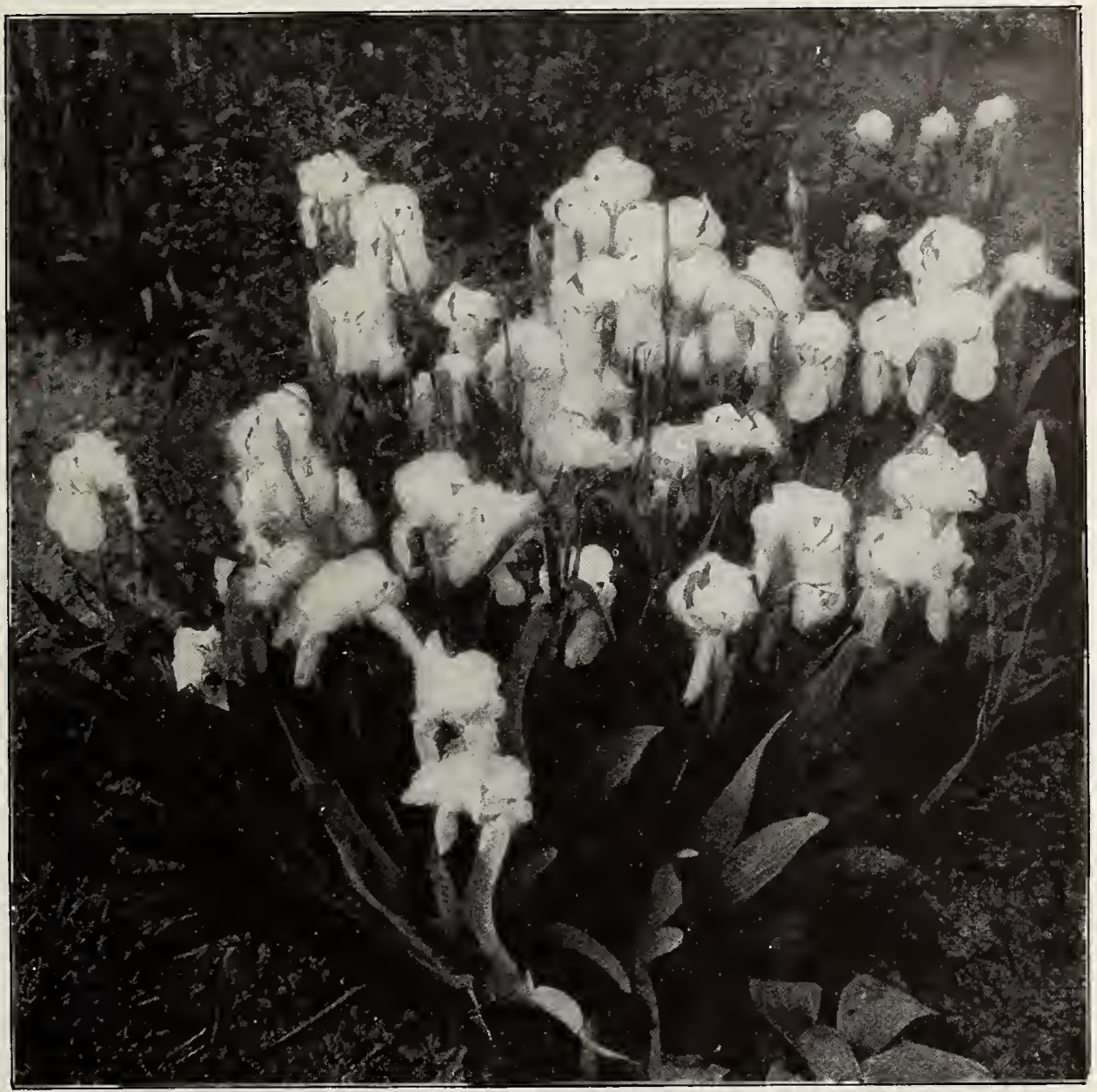

German Iris

Madam Chereau. Pearly white, daintily edged with lavender. Kharput. Extra-fine blue. 20 cts. each.

Queen of May. Lovely rose-lilac. $35 \mathrm{cts}$. each.

Queen of the Gypsies. Standards bronze, falls light purple.

Alvares. Standards light purple; falls dark velvety purple.

Ada. Standards dark bronze, falls dark maroon.

\section{Japanese Iris}

Some years ago a set of Japanese Iris (I. Kampferi) was sent to us from Japan to test, which was said to be identical with the collection in the Royal Gardens. We cannot vouch for this statement, as we have never been in Japan, but we have never seen another collection in America or Europe that would equal it in any way. The collection contained many colors and varieties we had never seen before, and the flowers were of remarkable size and beauty. When these Irises were in bloom they excited the greatest admiration and enthusiasm and it was hard to convince people that these unique and exquisitely beautiful flowers were as hardy as apple trees, and as easily grown as potatoes. They will thrive in any good garden soil, but if the soil is made very rich and deep, and flooded with water for a month before and during their blooming season, they will produce flowers of a wonderful size, sometimes 10 to 12 inches across. These Irises should be planted in full exposure to the sun. As the Japanese names are unintelligible and impossible to remember, we have renamed this collection.

Since the above collection was received we have annually added to it the newest varieties from Japan and new varieties selected from thousands of seedlings grown on our own grounds, until we now have what is unquestionably the firest and most complete collection of Japanese Iris in the world.

\section{PRICES OF JAPANESE IRIS}

Named varieties, described in the following list, 25 cts. each, $\$ 2$ per doz., $\$ 13$ per 100 , except where noted. American-grown, fine mixed, without names, $\$ 1.25$ per doz., $\$ 6$ per $100, \$ 50$ per 1,000

Alice Kiernan. Single. White, suffused with pale blue, center white, edged blue; extra large and fine; loveliest variety in cultivation. 50 cts. each, $\$ 5$ per doz.
Allegheny. Double. Pale lavender, striped white; late. $35 \mathrm{cts}$.

Amoret. Double. Blue, blotched and mottled with dark blue and reddish plum, yellow bar at base; late. 


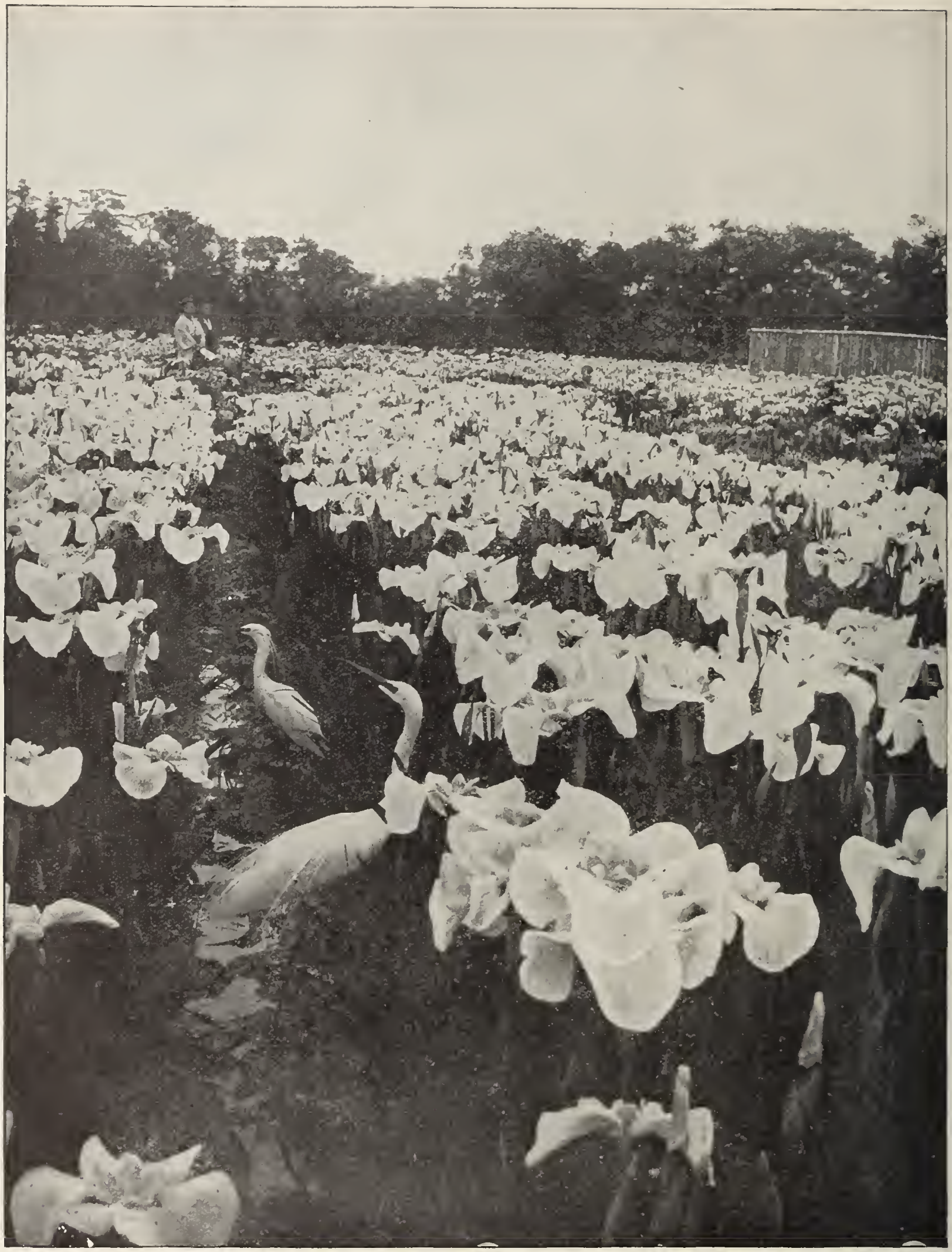

THE JUNE GLORY OF THE JAPANESE IRIS IN JAPAN (From The Country Calendar) All the varieties of this beautiful Iris succeed in American gardens 
JAPANESE IRIS, continued

Apollyon. Double. Reddish plum, striped white, base of petals yellow; large and fine.

Aurora. Single. White, freely striped and suffused with magenta. Blue Flag. Double. Indigo-blue, base of petals yellow; the last variety to bloom. 75 cts. per doz., $\$ 5$ per $100, \$ 40$ per 1,000 .

Captain C. W. Brown. New. Single. Extra large; pendulous petals; white, striped crimson-maloon; vigorous, tall. 75 ets. each.

Coquette. Double. Magenta, yellow center, feathered lilac.

Cygnet. Single. Purple and plum, blotehed white.

Delight. Single. Dark ros, purple at base of petals.

Dorothy. Single. Light maroon, blotched white.

Edward A. Woods. New. Single. Dark maroon, shading to white at margin of petals; extra large and distinct. \$1 each.

Esmeralda. Single. Magenta, penciled white, center white.

Gigantea. Double. Bluish purple, lightly striped white; vigorous grower and free bloomer. The earliest-flowering variety in the collection.

Glow. Double. Crimson-maroon; large and fine. 50 ets. each.

Harlequin. New. Three petals, large flower; delicately suffused and spotted with maroon, variable, sometimes splashed with large blotches of maroon. $\$ 1$ each.

Heart of Gold. Double. Extra-large, white flowers, yellow center. Hermione. Single. White, maroon center, petals penciled with blue. Hobart J. Park. New. Six petals; extra-large flower; white, lightly suffused with blue, center pale pink; extra fine. $\$ 1$ each.

Ida. Reddish plum, rich and velvety, narrow yellow band on base of petals. 50 ets. each.

James R. Mellon. Double. Extra-large flower; lilac, striped with purplish blue, purple center; distinct and fine.

J. C. Slack. Double. Lilac, heavily blotched with magenta and blue, yellow center; distinct.

J. Walter Thompson. New. Six petals; white striped and heavily margined light maroon, base of petals yellow. $\$ 1$ each.
Kitty. Single. Slightly suffused with pale blue. 50 cts. each. Lorna Doone. Double. White, delicately penciled with blue, yellow band at base of petals, blue center.

Mary Shattuck. New. Single. Rosy lavender, striped with violet very lovely. $\$ 1$ each.

Mont Blanc. Double. Pure white; large and fine. One of the finest of the white varieties.

Moonlight. Double. White flower, with yellow center; rich and dainty in effect.

Mrs. Henry L. Higginson. Single. Bright reddish maroon, center white.

Mrs. J. H. Ballantine. Single. Extra-large, white flower, delicately suffused with pale blue, margins of petals pure white; fine. $50 \mathrm{cts}$.

Mrs. Morris Brandon. New. Double. White, penciled decp blue. center dark purple; late and fine. 50 cts. each.

Mrs. William P. Snyder. New. Six petals; dark maroon, velvety texture; very late; extra fine. 50 cts. each.

Mrs. W. R. Massie. New. Single. Light maroon, blotched white; lovely. \$1. each.

Octavia. Single. White, dark center, petals distinctly netted with blue.

Purity. Double. Large; pure white; strong, vigorous plant.

Queen of the Whites. Double. White; vigorous grower.

Romola. Single. Lilac, striped with plum, plum center.

Rosalind. Double. Light purple, freely striped with white.

Snowdrift. Single. Pure white.

Springdale. Single. Bluish purple, slightly striped white. Exceedingly handsome.

W. H. Buttfield. Double. Center of petals white, heavily margined with magenta; vigorous grower.

Wm. F. Dreer. Double. White, penciled with lavender.

Wm. J. Matheson. Double. Reddish plum, base of petals yellow; large and fine.

\section{New Irises}

\section{Siberian Irises}

Sibirica, Snow Queen. An exquisite new hardy Iris; the flowers are of a snowy whiteness, large and well formed, produced in great abundance; foliage light and graceful. A gem for flower-border or waterside. 3 feet high. Award of Merit, R. H. S., June $24,1902$. 15 ets. each, $\$ 1.50$ per doz.

Sibirica superba. Large, violet-blue flowers; handsome foliage. Fine border plant and a grand subject for planting near water. 10 cts. each, \$1 per doz.

\section{German Irises}

Stylosa innocenza. Exquisitely beautiful white flowers, tinted with blue and yellow; almost pure white; a color never before obtainable in German Irises. $20 \mathrm{cts}$. each, $\$ 2$ per doz.

Aurea. A pure, rich, deep yellow; very distinct and fine. 35 cts. each, $\$ 3.50$ per doz.

\section{Dwarf Bearded Irises}

These Irises have flowers similar to the German Iris, but are much dwarfer and bloom in April. They are extremely free-flowering and desirable.

Socrates. Bright claret-red, falls deeper claret, beard yellow. 25 each.

Orange Queen. Beautiful clear yellow, with orange beard. $10 \mathrm{cts}$. each, $\$ 1$ per doz.

\section{Native Irises}

Pseudacorus. Semi-aquatic variety; valuable for planting in swamps and on the edge of ponds; vigorous plant with lovely yellow flowers. 15 cts. each, $\$ 1.50$ per doz.

Pseudacorus variegata. Same as above, with variegated foliage. 15 cts. each, $\$ 1.25$ per doz.

Versicolor. The Common Blue Flag of our swamps and meadows; valuable for naturalizing. 10 cts. each, $\$ 1$ pcr doz., $\$ 6$ per 100 .

\section{Iris pumila}

These bcautiful little Irises do not grow over 4 inches high, and bloom in April and May. They are fine for bordering flower-beds or planting in front of the tall Irises. Mixed varieties. 10 cts. each, $\$ 1$ per doz, $\$ 6$ per 100 . 


\section{Tall English Delphiniums}

We are tempted to say" that the Inproved English Delphiniums are the most beautiful hardy plants in cultivation, but we are also tempted to say this of a score of other things, and, of course, it is impossible to say which is the most beautiful of hardy plants, for they have such an immense variety of beauty that the wonder grows that peoples continue to plant, by the million, bedding plants which have little or no beauty, are an annual expensc, and cost quite as much as hardy plants whose first cost is their only cost, and which incrcase in size, in beauty, and often in quantity, year after year. These Delphiniums may not be the most beautiful hardy plants, but they are among the most beautiful, and nothing can be more distinct and satisfaetory. They are stately and picturesque, some varieties growing 8 feet high in rich soil; they have immense spikes of most beautiful flowers of every imaginable shade of blue, and their season is a long one; in fact, they will bloom from spring till fall if properly treated.

CULTURE OF DELPHINIUMS. - The culture of Delphiniums is execedingly simple, and the results out of all proportion to the slight amount of eare necessary. They thrive in almost any position, and may be planted at any time of the year, provided that in summer the plants are not too forward, and that they be wcll watered if the weather be dry. The soil may be a rich, friable loam, which suits them finely; but any soil, even hot and sandy, if well watcred and manured will give excellent results. Dig deeply-trenching is better, -add plenty of well-rotted manure, and plant about $2 \frac{1}{2}$ feet apart. Placed in lines, as a background to a bordcr, or in groups of, say, three plants at intervals, the effect of the Delphinium is exceedingly fine. They look well in beds, also, arranged at the same distance apart each way. They are grand grown in masses of large groups of separate colors, and may be associated with shrubs with great advantage, succeeding well in shrubberies because of their robustness. A succession of flowers may be cxpected from spring to early autumn, especially if the spikes which have done flowering early be cut down to the ground; fresh growth will then be produced which will give blossom. Copious watering in summer will be attended by increased size of spike and flower; in fact, in seasons of prolonged drought, water is absolutely a necessity on many soils if the varieties are to exhibit themselves in their true size and bcauty of flower and spike. Top-dressing is greatly recommended on certain soils, instead of the bare surface of the ground being left exposed to the sun. Some of the neater dwarf alpine and other hardy plants may be utilized to plant between and around Delphiniums. Coal ashes strewn over the crowns will protect the plants from slugs through winter and spring. As we have intimated, any garden soil suits the Delphiniums; it is, however, necessary to secure sorts such as are offered below in order to obtain an effect superior to that afforded by the old smaller-flowered varieties. No amount of liberal treatment will cause the smaller-flowered kinds of a few years back to develop into the gorgeous hybrids of today.

\section{SPEGIAL OFFER OF IMPROVED ENGLISH DELPHINIUMS}

I want every one who receives this price-list to try these improved English Delphiniums, and to that end offer them at extremely lon prices. I guarantee that they will give unqualified satisfaction in every instance and will be a revelation of beauty to most people.

. Per doz. 100

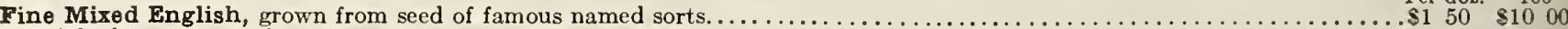

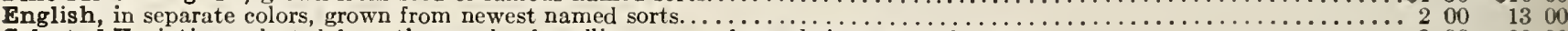

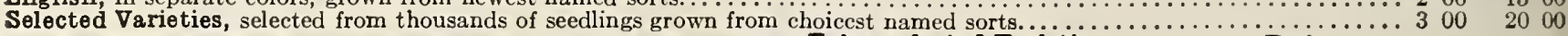

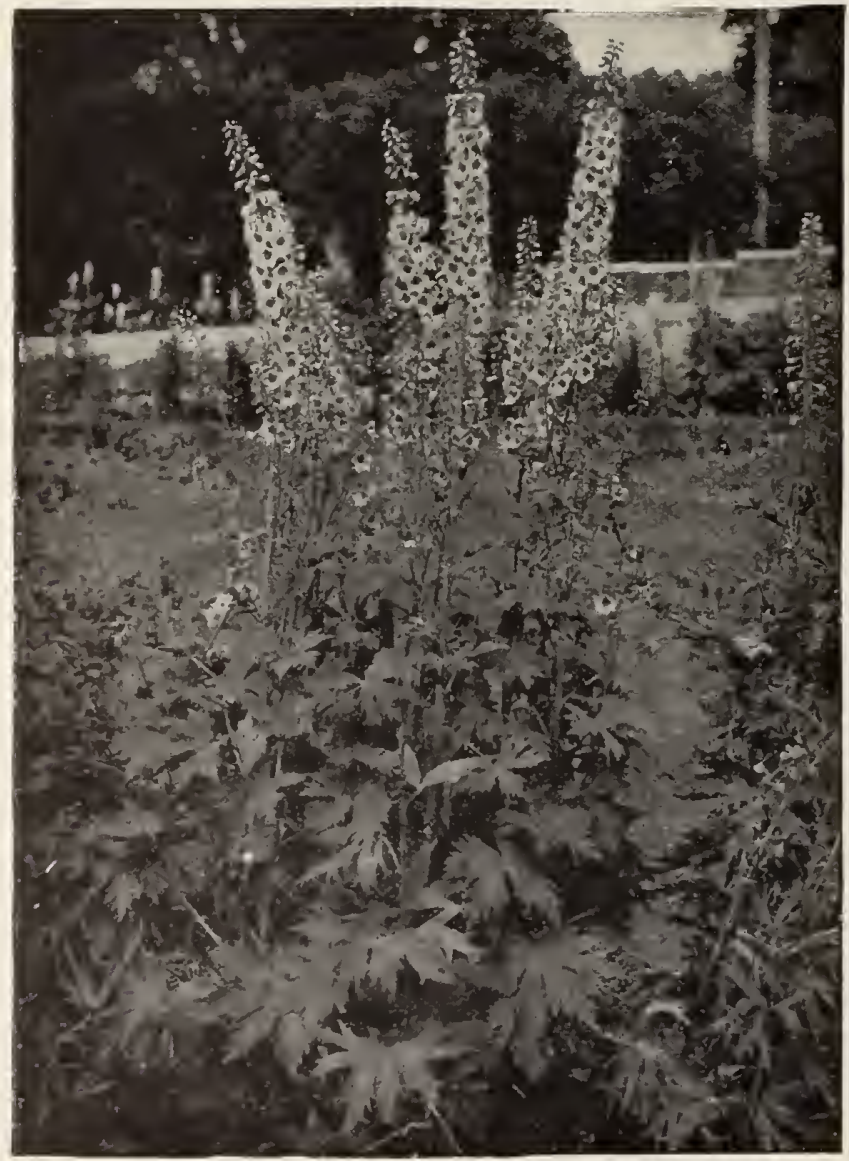

Specimen plant of Improved English Delphiniums
Estra-selected Varieties............Each, 50c... 500

\section{Standard Sorts}

Belladonna. The freest and most continuous blooming of all, never being out of flower from the end of June until cut down by hard frost. The clear turquoise-blue of its flowers is not equaled for delicacy and beauty by any other flower. $25 \mathrm{cts}$. cach, \$2.50 per doz., $\$ 16$ per 100 .

Chinense. A very pretty variety, with fine, feathery foliage and intense gentian-blue flowers in open panicles. $15 \mathrm{cts}$. each, $\$ 1.50$ per doz., $\$ 10$ per 100 .

Chinense album. A pure white form of the above. 15 ets. each, $\$ 1.50$ per doz., $\$ 10$ per 100 .

Formosum. The old favorite dark blue with white center: 3 to 4 feet high. Very vigorous, free-flowering, and one of the best. 15 cts. each, $\$ 1.50$ per doz., $\$ 8$ per 100 .

Formosum colestinum. Charming light blue variety of above; most exquisite shade of blue. $15 \mathrm{cts}$. each, $\$ 1.50$ per doz., $\$ 8$ per 100.

\section{New Phloxes}

The following are the best new Phloxes recently received from Europe.

Antonin Mercie. Light ground-color, one-half of each petal suffused bluish lilac.

Asia. One of the prettiest in the collection. A delicate shade of mauve, with a crimson-carmine eye.

Baron Van Dedem. Brilliaut cochineal-red with salmon shadings; a rich color.

General Van Heutsz. Brilliant salmon-red, white center. 25 cts.

Goliath. A giant in growth, in rich soil 5 fect high; bright crimson(armine, with deeper eye.

Gruppenkonigen. Clear flesh-rose, with deeper eye; lovely. 25 ets.

Lady de Grey. Deep purple, with erimson eye; dark foliage; $4 \mathrm{ft}$.

Lady Grisel. White, shaded soft gray; buds violet; $31 / 2$ feet; extra fine.

Lady Molly. Soft pale pink flowers of perfect form; 2 feet; extra fine. Lady Satanella. Very large flowcrs of a glowing orange; $3 \mathrm{ft}$.; extra fine.

Meteor. Lovely shade of soft salmon-rose; $3 \mathrm{ft}$. ; extra fine.

Rynstrom. A splendid improvement on Pantheon; color not unlike that of Paul Neyron rose; fine for massing. Except where noted, 20 cts. each, $\$ 2$ per doz. 


\section{Plants Suitable for Naturalizing}

The most delightful and least troublesone form of gardening is the planting of suitable hardy plants and bulbs in the rougher parts of the grounds and allowing thein to take eare of themselves exactly the same as the wild flowers. Many plants are perfectly at home in the grass; of course we do not mean the grass of a lawn which must be mown, but the grass of ineadows and orcharcls, along streams and ponds arrd on the edges of wools and wild shrubbery. We give a few suitable varieties bclow, but there are seores of others, and we shall be glad to send a list of these when desired.

\section{BELLIS perennis (Double} English Daisy). There is nothing more cliarming for naturalizing than this popular little flower endeared to thousands by Robert Burns' delightful poem. It can even be grown on the lawn, as it aceommodates itself to the lawn-mower. White and pink varieties. 50 cts. per doz., $\$ 3.50$ per 100 .

ASTER Novæ-Anglim rubra. Everybody knows the wild Asters which make such beautiful pictures along the roadsides in the fall, but this splendid largeflowered variety does not grow wild throughout the country. Either for naturalizing, for the garden, or for planting among shrubbery, there is no finer fallflowering plant. $\$ 1.50$ per doz., $\$ 10$ per 100 .

AQUILEGIA Canadensis. This beautiful native Columbine grows wild in many parts of the country. There is no finer subject for naturalizing. It is perfectly at home on a rocky bank or in the grass. $\$ 1.50$ per doz., $\$ 10$ per 100 .

Corulea (True). This charming blue and white Columbine is one of the loveliest of garden plants and just as desirable for naturalizing. $\$ 1.75$ per doz., $\$ 12$ per 100 .

Chrysantha. A bright yellow Columbine that is in bloom for two months. Used with $A$. corrulea, blue, and $A$ Canadensis, red, a most charming picture can he made. $\$ 1.50$ per doz., $\$ 8$ per 100.

HARDY ENGLISH PRIMROSE. One of the loveliest sights in all England are the hardy primroses in blcom in orchard and meadows in early spring. In many places the ground is earpeted with their lovely canary-yellow flowers, wnich are delightfully fragrant. They are equally hardy here, and nothing ean be more delightful, either for naturalizing in orchard, meadow, along a brook, or planting in borders or along the edge of a shrubbery border. 10 ets. each, \$1 per doz., \$5 per 100 .

CORONILLA varia. One of the prettiest floral pietures we have ever secu was a great mass of this in one of the nueadows of Franklin Park, Boston. It eompletely covered the ground and had piled itself up in a pleasing tangled mass of green foliage and white and pink bloom. $\$ 1.25$ per doz.

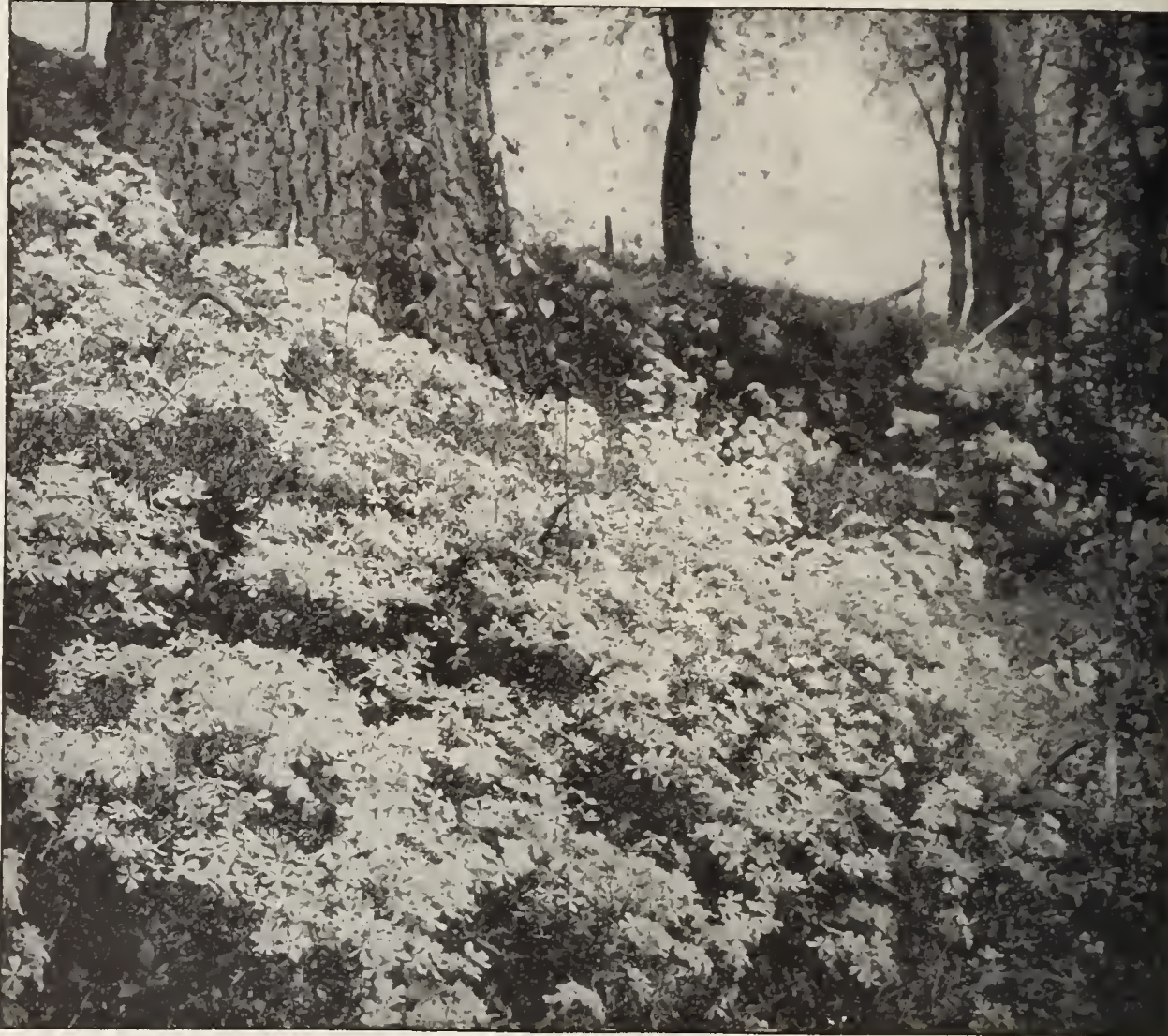

Phlox divaricata Canadensis, naturalized

PHLOX Carolina. A beautiful, bright pink Phlox, which cannot br surpissed for naturalizing. Grows 12 to 16 inches high, and is eovered with bright, showy flowers throughout the month of June. Thrives in sun or shade, but will flower more frcely in the sun. $\$ 1.50$ per doz., $\$ 10$ per 100 .

\section{Phlox divaricata Canadensis}

One of our native varieties that is but rarely met with, and which has been introdueed into Europe the past few years as a novelty. A plant that is eertain to mect with much favor when better known, as nothing ean produce such a cheerful correr in the garden in very early spring. Frequently beginning to bloom carly in $A$ pril, it continues until about the niddle of June, with large, bright lilac-colored flowers, which arc produeed on stems ahout 10 inches high, in large, slowy heads, and are very fragrant. Extremely finc for naturalizing in the woods and shady places. Although this Phlox is usually found grcwing wild in shady places, it will do better if it is planted where it has full exposure to the sun and will bloon more freely. $10 \mathrm{cts}$. each, $s_{+}$per doz., $\$ 6$ per 100.

\section{Other Choice Hardy Perennial Flowers Suitable for Naturalizing}

Butterfly-weed (Aselepias).

Orange or yellow day-lilies (Hemeroeallis).

Sweet rocket (Ilesperis).
Anemone Pennsylvaniea.

Japanese anemones, white.

Iris versicolor.
Iris Sibiriea, rar. sanguinca.

Lythrum roseum.

Giant knot-weed.
Forget-me-not (Myosolis).

Phlox paniculata.

Goat's beard (Spirca aruncus). 


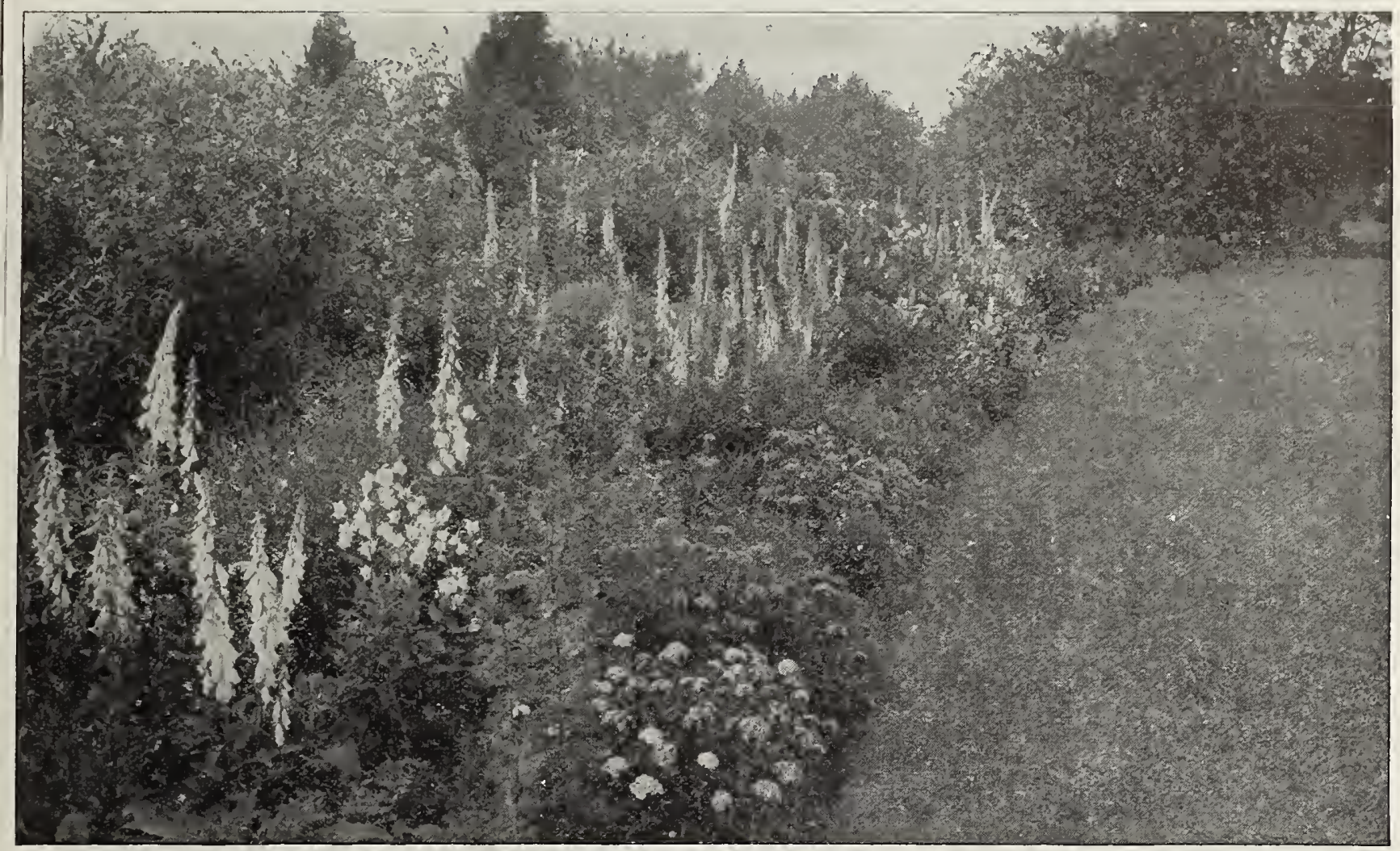

Border of Hardy Plants

\section{Some Notable Hardy Plants}

Elsewhere will be found a very complete list of hardy plants, but the following varieties are especially desirable, and I am in a posi tion to furnish them in quantity at very low prices.

\section{Aquilegias}

All of the single, long-spurred Aquilegias, or Columbines, are extremely beautiful, and a collection of them should be a feature in every garden. Foremost among these choice plants are our native Aquilegias. If these and other choice hardy plants were as well known as bedding plants, the day of geraniums, coleus, and other commonplace plants would soon be over. The flowcrs of these Aquilegias are most lovcly and delicate, ranging from white to crimson, including shades of blue and yellow. The exquisite Rocky Mountain Columbine, Aquilegia corulea, is one of the loveliest flowers in cultivation, and it and Aquilegia Canadensis, which grows wild so plentifully in many localities, are both fine for naturalizing and will thrive if planted in the grass of meadows and allowed to take care of themselves. They are also fine for the formal garden. Assorted varieties, our selection, $15 \mathrm{cts}$. each, $\$ 1.25$ per doz., $\$ 8$ per 100 . For complete list of varieties, see general list of hardy plants.

\section{Armeria (Thrift)}

Attractive dwarf plants that will succeed in any soil, forming evergreen tufts of bright green foliage, from which innumerable flowers appear in dense heads, on stiff, wiry stems about 9 inches high. They flower more or less continuously from early spring until late in the fall. Very effective in the rockery and indispensable in the border. Fine for edging beds and borders on account of extremely dwarf habit of growth.

Formosa. Pink.

Cephalotes. Bright, rosy pink flowers.

Maritima splendens. Bright pink; fine.

15 cts. each, $\$ 1.25$ per doz., $\$ 7$ per 100

\section{Calimeris incisa}

A graccful little plant with finely cut foliage and the prettiest of all single white daisy-like flowers. Blooms all summer and is distinct and fine. 15 cts. cach, $\$ 1.50$ per doz., $\$ 8$ per 100 .

\section{Stokesia cyanea}

\section{(The Cornflower, or Stokes' Aster)}

A most charming and beautiful native hardy plant. The plant grows from 18 to 24 inches high, bearing freely, from early in July until late in October, its handsome lavender-blue centaurea-like blossoms, which measurc from 4 to 5 inches across. It is of the easiest culture, succeeding in any open sunny position, and not only is it desirable as a single plant in the hardy border, but it can also be used with fine effect in masses or beds of any size. 15 cts. each, $\$ 1.50$ per doz., $\$ 8$ per 100 .

Alba. Pure white variety of above. 15 cts. each, $\$ 1.50$ per doz.

\section{Ranunculus acris f1. pl.}

A double-flowered form of our common Buttercup. Clear yellow flowers in May and June; dainty and beautiful. 15 cts. each, $\$ 1.50$ per doz.

\section{Arenaria montana}

Forming fine mounds smothered with large snowy white flowers in early summer. A valuable rock-garden and border plant; grows 6 inches high. 20 cts. each, $\$ 2$ per doz. 


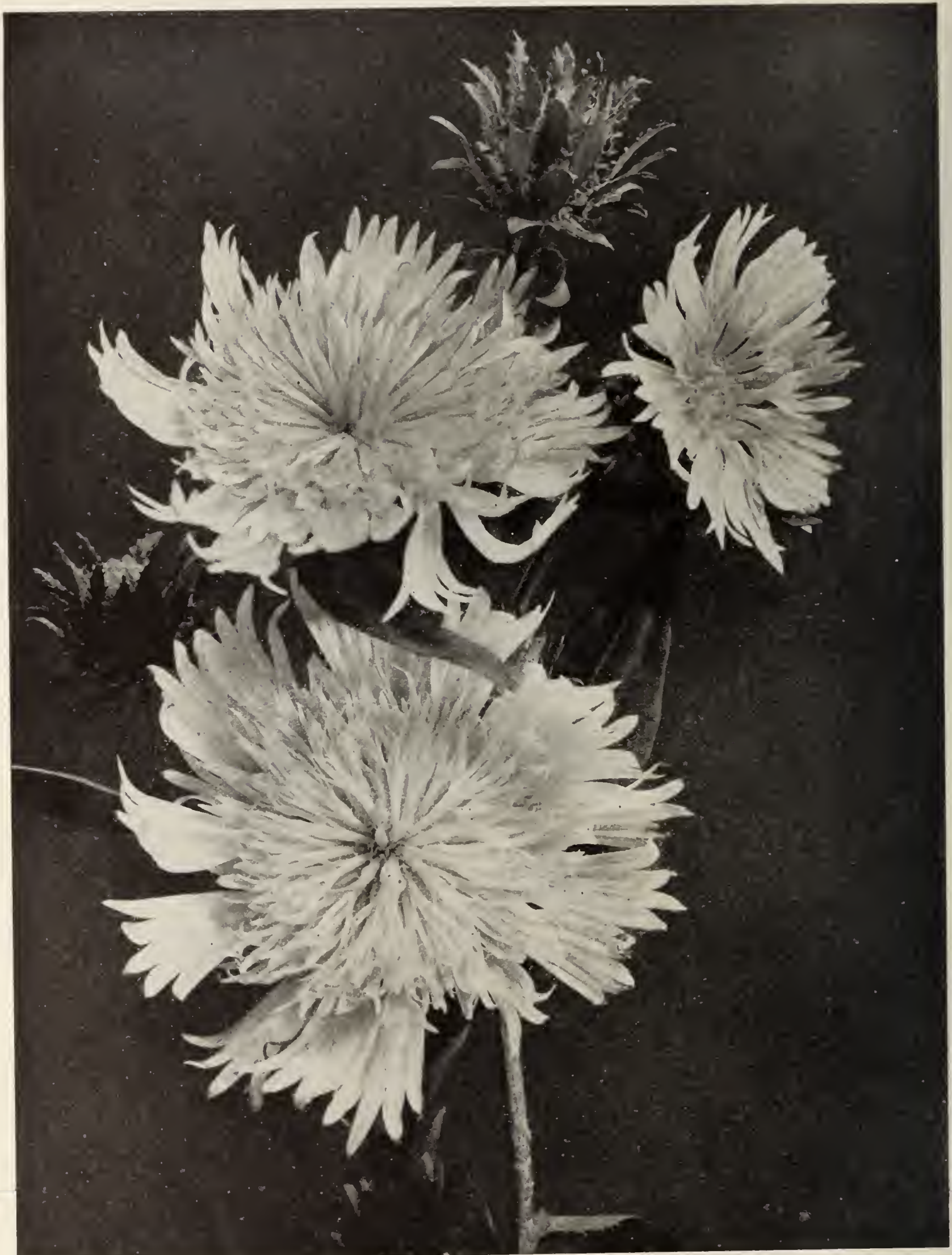




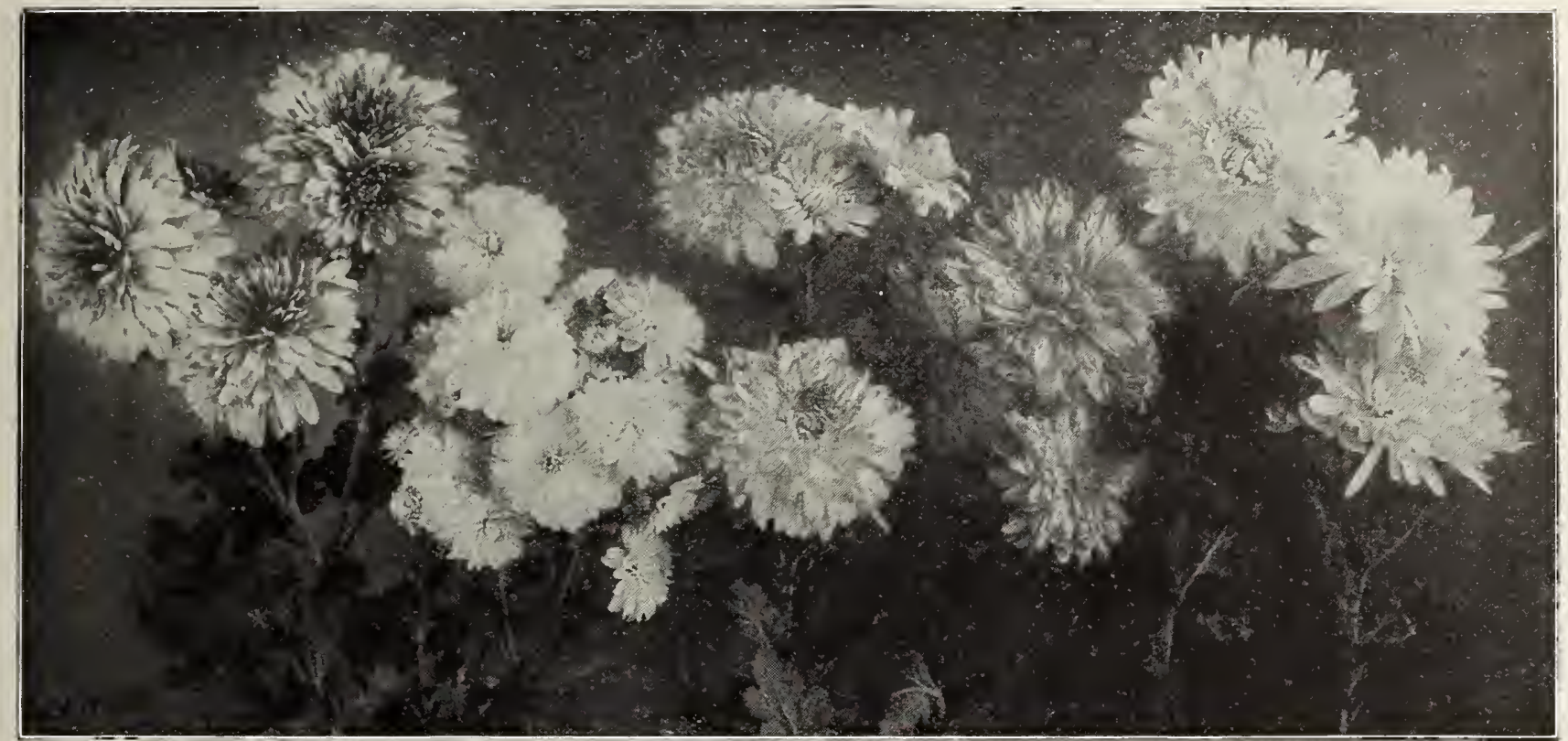

Pompon Chrysanthemums

\section{Polemonium reptans}

\section{(Jacob's Ladder)}

Useful border plants about 12 inches high, with deep green, finely cut foliage and spikes of showy blue flowers in May and June; of graceful growth. $15 \mathrm{cts}$. each, $\$ 1.50$ per doz.

\section{Spiraea filipendula}

A plant of decided merit, growing 2 to $2 \frac{1}{2}$ feet high, with fern-like foliage, with loose clusters of white flowers; blooms end of May. $15 \mathrm{cts}$. each, $\$ 1.50$ per doz.

\section{Phlox Carolina}

A very desirable native Phlox, growing about 12 inches high. Bright pink flowers in May and June. $15 \mathrm{cts}$. each, $\$ 1.25$ per doz.

\section{Blackberry Lily}

\section{(Pardanthus Sinensis)}

Lily-like flowers of a bright orange color spotted with red, which are succeeded by seeds that resemble blackberries. Very showy and desirable. $15 \mathrm{cts}$. each, $\$ 1.25$ per doz.

\section{Large-flowered Chrysanthemums}

We have collected from farm gardens some of the old-fashioned Chrysanthemums which are really hardy and which bloom in October and November, after all other outdoor flowers are gone. Often in bloom when the snow is on the ground old, established beds are very showy. 3 to 4 feet high. When in bloom are a perfect mass of flowers. Our stock is grown in pots and can be delivered any time during the spring or summer. We offer four large-flowered varieties-White, Pink, Blush and Yellow. $15 \mathrm{cts}$. each, $\$ 1.50$ per doz.. $\$ 10$ per 100. Delivery in May.

\section{Chrysanthemum latifolium}

We have at last succeeded in getting a stock of the true variety of this most beautiful of all the Single Daisies. It is one of the most satisfactory hardy plants for the garden or border, and produces its large, beautiful single white flowers in the greatest profusion. It should be included in every collection of hardy plants. 15c. each, $\$ 1.50$ per doz., $\$ 10$ per 100 .

SHASTA DAISY. This new California Daisy has been introduced with a great hurrah, and may be all that is claimed for it, but, so far, in our garden, does not appear to be so good as Chrysanthemum latifolium, which it resembles. However. there is a large demand for it and it is our business to supply the demand. 15 cts. each, $\$ 1$ per doz.

PRINCESS HENRY. This has larger flowers than $C$. latifolium, and really is an improvement. $15 \mathrm{cts}$. each, $\$ 1.50$ per doz.

\section{Pompon Chrysanthemums}

These are the small-flowcred Chrysanthemums of the old-fashioned gardens, and bloom in October and November after almost all flowers are gone. They are showy in the garden and effective as cut-flowers, and, being perfectly hardy and of easiest culture, can be successfully grown in any garden. We offer a fine collection of the best varieties, ranging from white to deep crimson. 15 ets. each, $\$ 1.50$ per doz., $\$ 8$ per 100 Globe d'Or. Light yellow; extra.

Regulus. Bronze-yellow.

Wm. Westlake. Dark red, center yellow.

Bob. Pink, fades to white.

Mirs. Vincent. Dark crimson.

Julia Iagravere. Dark crimson; large flowers of good form.

Flora. Bright yellow.

Trojan. Dark yellow, striped coppery red.

Chrysanthemum latifolium

Golden Pheasant. Golden yellow. 


\section{POMPON CHRYSANTHEMUMS, continued}

Eagle d'Or. Golden yellow.

Golden Pheasant. Rich golden yellow.

Pink Beauty. Very snill, button-like, pink flower.

Rhoda. Apple-lolossom-pink.

Rosinante. Pile jink, center lighter.

Rubra minima. Vrry small, button-like flowers; coppery red.

Tiber. Yellow atul ('op)erererel.

While these Chrysanthemums are hardy, they are better for being covered with 2 or 3 inches of manure in the winter.

\section{Physostegia Virginica alba}

An Ameriean plant, and by no means a new one; yet it is a flower so unique in its make-up that it stands apart from all others and alone. For massing, planting in association with other appropriate varieties in the border, for planting with shubbery or for cut-bloom, it is unrivaled. In value it is not equaled by the popular Golden Glow; and it possesses a eoustitution just as rugged. Its large, rraceful spikes of white flowers are produced in greatest profusion from about the middle of June, and if kept cut (so as not to produce seed) it continues to flower in a perfect mass of bloom until frost. The flowers themselves are intensely interesting and attractive, resembling large heather. The stems are long, square, thick, rigid and strong, holding the flowers in a dignified and stately manner when upon the plant and when cut. The plants form large, dense elumps, 3 or 4 feet high, and require no petting, sueeeding on all kinds of soil and in all situations. 15 cts. eaeh, $\$ 1,50$ per doz., $\$ 8$ per 100 .

\section{Polyanthus, or Cowslip}

This eharming spring-blooming plant belongs to the Primrose family, the hardy varieties of whieh are so very popular in England, but are rarely seen in this country, owing partly to an impression that they cannot be grown in this climate. This is a mistake, as they do very well here. For the front of borders and shrubbery, for spring bedding, and for naturalizing in moist and partly shaded plaees nothing ean be finer. The eoloring in the flowers is especially rich and fine. At this writing we have a long border of these plants in bloom in our garden, and nothing gives us greater plcasure. They are so eharming in habit, rich and varied in coloring, and so carly to bloom, coming with the spring-flowering bulbs, that nothing can be more acceptable. We use them freely for deeorating the dining-table and library windows, taking plants up from the border and putting them in fern-dishes and pots, where they go on blooming as if they had never been disturbed. Their hardiness has been pretty well settled by the severe winter of 1911 and 1912. The minimum temperature at our country plaee was 24 degrees below zero. Not a single Polyanthus was injured, and they were planted in wet soil at that. 15 cts. each, \$1 per doz., \$6 per 100 .

Large-flowered White. An improved variety, with very large flowers; very fine. 20 ets. eaeh, $\$ 1.00$ per doz., $\$ 6$ per 100.

\section{Hardy Primroses}

The hardy Primroses do not receive the attention they deserve. They are charming little spring-flowering plants of the easiest culture, and thrive in partial shade. Very valuable for naturalizing and for elging beds and borders. They are among the modest things of earth which have a charm and loveliness all their own.

Primula Cashmeriana. A rare and beautiful Primrose with rich violet-purple flowers. 20 ets. each, $\$ 2$ per doz.

Primula Japonica. Showy; perfectly hardy; eolors ranging from pure white to rieh purplish erimson. 25 ets. each, $\$ 2.50$ per doz.

Primula frondosa. A beautiful hardy Primrose, with heads of rosy lilac flowers rising from tufts of silvery foliage. 15 ets. caeh, $\$ 1.50$ per doz.

\section{Dianthus barbatus (Sweet William)}

That old-fashioned favorite, the Swcet William, has almost disappeared from our gardens; nore's the pity, for its place has been taken by plants of far less beauty. The Sweet William is a fine old plant which produces great masses of bloon of extremely rieh and varied colors. The flowers are very lasting and fine for cutting. The plants offered are grown from the finest strains to be obtained in Fngland. We offer them in pink, white, crimson, scarlet or mixed colors. Fine, large plants, 15 ets. eaeh, $\$ 1.25$ per doz., \$ $\$$ per 100.

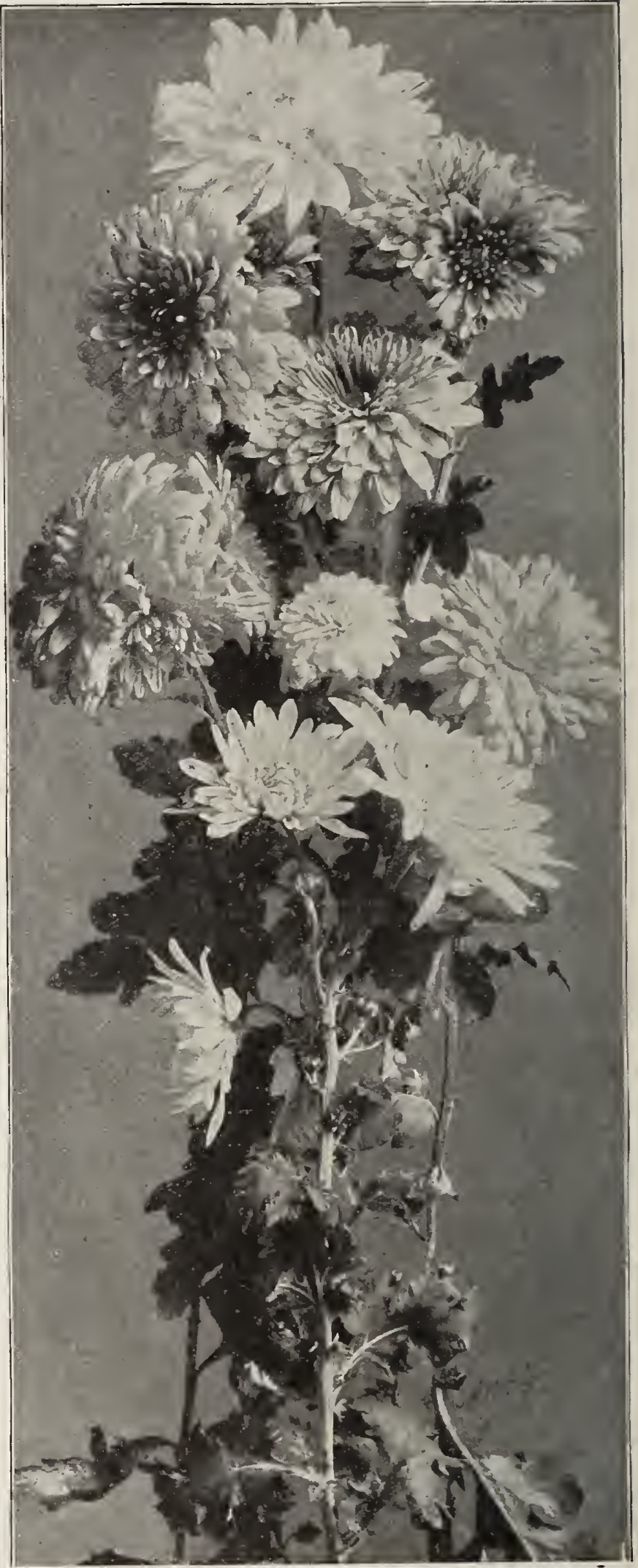

Hardy Cbrysanthemums (see page 45 ) 


\section{Epimedium (Barrenwort)}

A genus of dwarf-growing plants with leathery foliage and panieles of lovely white, yellow and lilac-colored flowers. The foliage of all the varieties offered below assumes the most beautiful tints of eolor in autumn.

Lilacea. Beautiful lilae.

Niveum. Pure white.

Muschianum. Creamy white. Sulphureum. Light yellow.

Any of the above four varieties, 20 cts. each, $\$ 2$ per doz.

\section{Pentstemon pubescens}

A very showy variety, with rosy purple flowcrs, blooming in July and August. $15 \mathrm{cts}$. cach, $\$ 1.50$ per doz.

\section{Hardy Ferns}

Varicties marked * require shade; those marked $\dagger$ sueceed in open border.

*Adiantum pedatum (Maidenhair Fern).

*Aspidium acrostichoides (Wood Fern).

* " marginale.

* “ Goldianum (Shield Fern).

$\dagger$ Asplenium Filix-fœmina (Lady Fern).

* " Thelypteris.

$\dagger \quad$ “ Trichomanes (Spleenwort).

$\nmid$ Dicksonia punctilobula (Gossamer Fern).

Onoclea sensibilis (Sensitive Fern).

$\dagger$ " Struthiopteris (Ostrieh Fern).

†Osmunda gracilis (Flowering Fern).

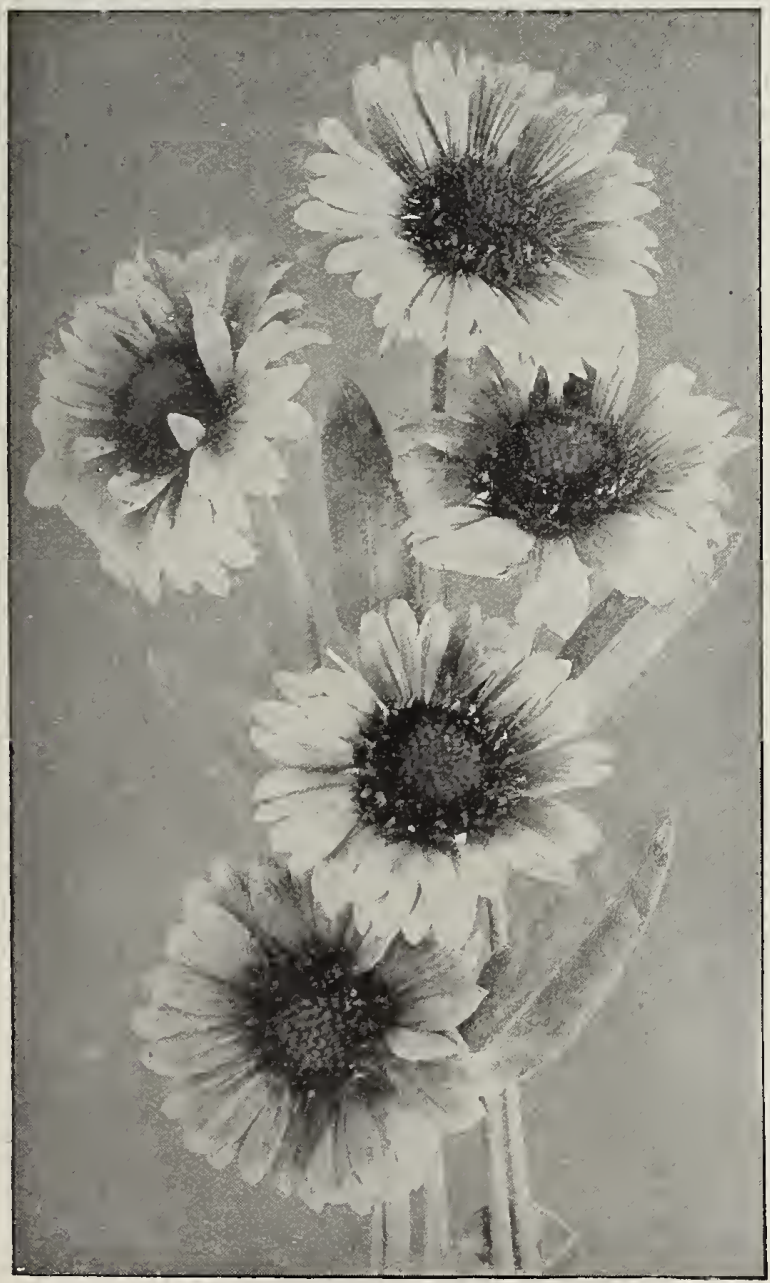

Improved Gaillardias

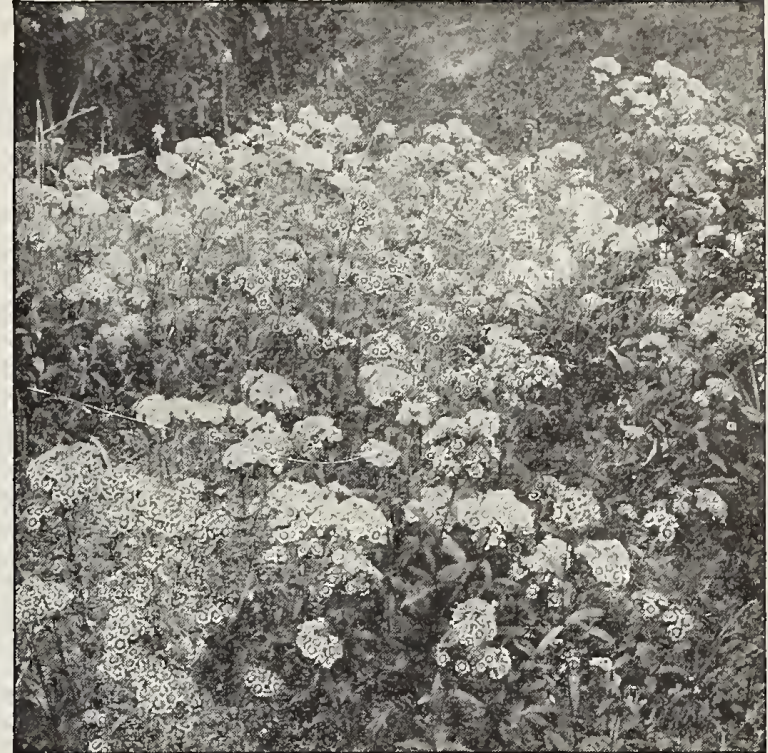

Dianthus barbatus (see page 34 )

HARDY FERNS, continued

tOsmunda Claytoniana (Flowering Fern).

$\dagger$ " cinnamomea (Cinnamon Fern).

regalis (Royal Fern).

Polypodium falcatum.

*Woodsia obtusa.

*Woodwardia angustifolia (Chain Fern.)

$\dagger$ " Virginica.

Any of the above Ferns, 15 ets. each, $\$ 1.50$ per doz., $\$ 10$ per 100

\section{Foxglove (Digitalis)}

In England the Foxglove grows wild, but, notwithstanding this, it is a great garden favorite, as it well deserves to be. For stately and picturesque beauty it is not to be surpassed and, planted in masses in the garden among shrubs or naturalized on the edge of woods, in the orehard or along brooks, it is extremely effectivc and satisfactory. Strictly speaking, it is a biennial, but, as it renews itself from selfsown sced, it may be treated as a perennial. Mr. Falconer has naturalized thousands of Foxgloves in Schenley Park, and nothing he has planted attracts more attention and admiration. Planted in the fall, Foxgloves will bloom well the following season. I offer a fine lot of strong plants, grown from the best strains obtainable in Europe. 15 cts. each, $\$ 1.25$ per doz., $\$ 7$ per 100 .

\section{Improved Gaillardias}

We consider the Gaillardia one of the most beautiful and desirable hardy plants in cultivation, and believe our strain of these brilliantflowered plants to be the finest extant. We offer these plants for less than they have ever been sold for, either in this country or Europe. Though sueh an ornamental addition to the herbaceous border, the perennial Gaillardia is content with extrcmely simple treatment. Dig the soil deeply and enrich with well-rotted manure. We reeommend the Gaillardia for bedding purposes as well as for borders. Give a moderate amount of room and peg down, and a grand effeet is to be obtained. Every one will have noticed how grandly Gaillardias have thriven through the recent drought; they seem hardly to need water, but we reeommend watering liberally to insure the finest flowers. The Gaillardia whieh Kelway \& Son have been so suecessful in improving and popularizing is, of eourse, simply invaluable as a cutfiower, on aecount of its being so lasting when gathered and so brilliant and beautiful. The gay blossoms are obtainable in perpetual profusion from June to November, and the greater the drought and searcity of other flowers the more the utility of the perennial Gaillardia is demonstrated. No more brilliant and beautiful sight ean be imagined than a large bed of Gaillardias, with their profusion of highly eolored flowers of all shades: Some of the varieties of this improved strain measure fully 5 inehes in diameter. Mr. Robinson, in the English Flower Garden, recommends that they should be planted in bold groups, and remarks that no plants have finer effect in a bed by themselves, and we quite agree with him. Fixtra strong, fine plants, in a splendid assortment of colors, which will be sure to give complete satisfaetion. $15 \mathrm{cts}$. each, $\$ 1.25$ per doz., $\$ 7$ per 100 . 


\section{Geum (Avens)}

Pretty border plants, growing about 18 inches high, and producing brilliant. showy, bright-colored flowers during the greater part of the summer and fall.

ATROSANGUINEUM. Large, dark crimson flowers.

COCCINEUM. Showy scarlet flowers.

15 ets. each, \$1 per doz.

\section{Helianthus}

Løtiflorus. The best of the summer-blooming varictics of hardy Sunflowers; flowers 3 inehes in diameter and freely produced. Plant grows 3 to 4 feet high, and spreads rapidly. Fine for eutting, for the border, and for planting among shrubs. 15 cts each, \$1.25 per doz., \$7 per 100.

H. G. Moon. New. A grand seedling variety with abundanee of large rieh golden yellow flowers, rising well above the foliage, extra fine. Height 4 feet. August and September. Award of merit, R. H. S. 15 cts. each, $\$ 1.50$ per doz.

Miss Mellish. An improved variety of Helianthus latiflorus; of taller growth and having larger flowers. A deeided improvement and most beautiful sort. 15 ets. each, $\$ 1.50$ per doz.

\section{Hibiscus Moscheutos}

We wish to eall attention to this extremely showy and satisfaetory plant. It thrives in any garden soil, and is equally desirable as a garden plant or naturalized along the edges of brooks and ponds, or planted among shrubs. The plant grows 4 or 5 fcet high, is very bushy, and in August and September is eovered with immense single flowers 6 to 8 inches across, from pure white to deep rose in eolor. The pink variety of this plant is the one that grows so abundantly in the Jersey meadows, consequently it is very desirable for marsh and swamp planting.

In soparate colors. White, blush-pink and deep rose. 15 ets. each, $\$ 1.50$ per doz., $\$ 10$ per 100 .

Mixed Colors. Strong plants at a specially low priee. $\$ 1$ per doz., $\$ 6$ per 100 .

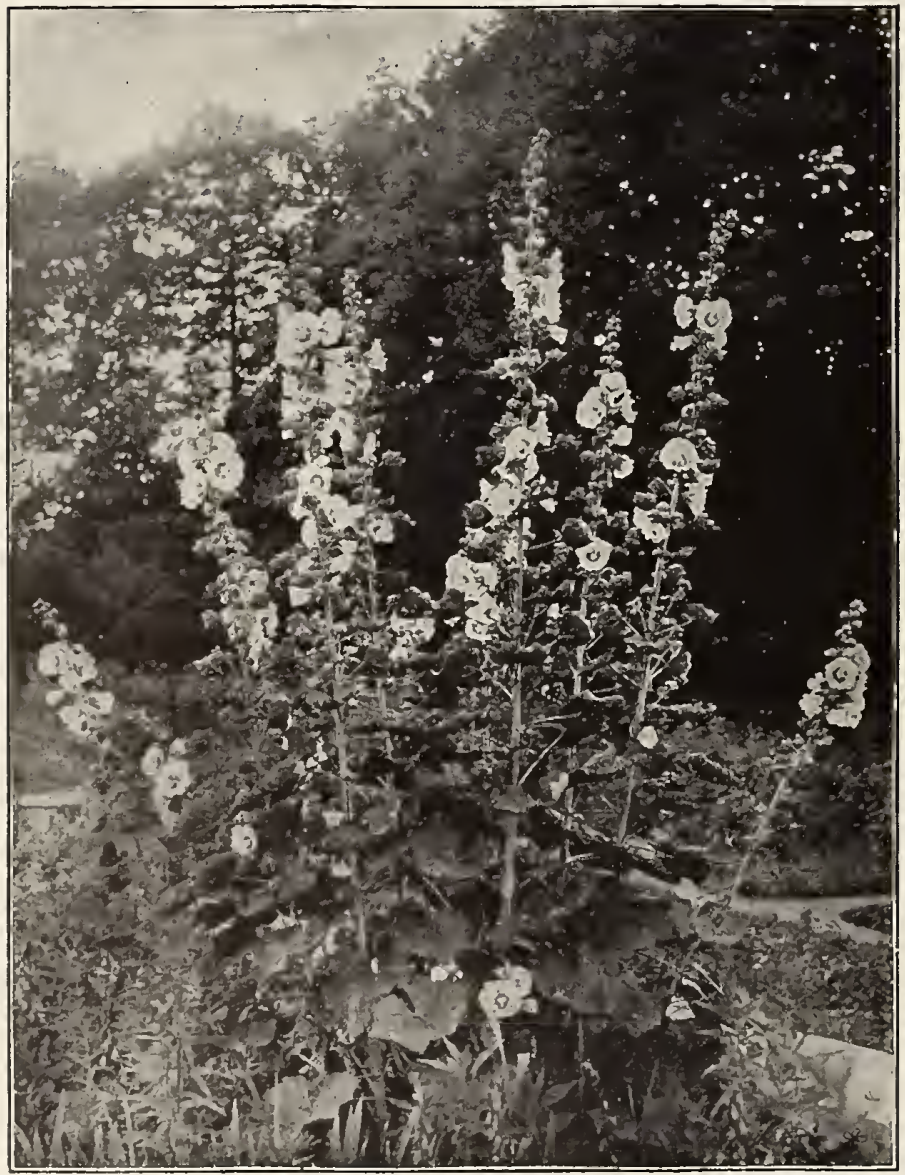

Single Hollyhocks

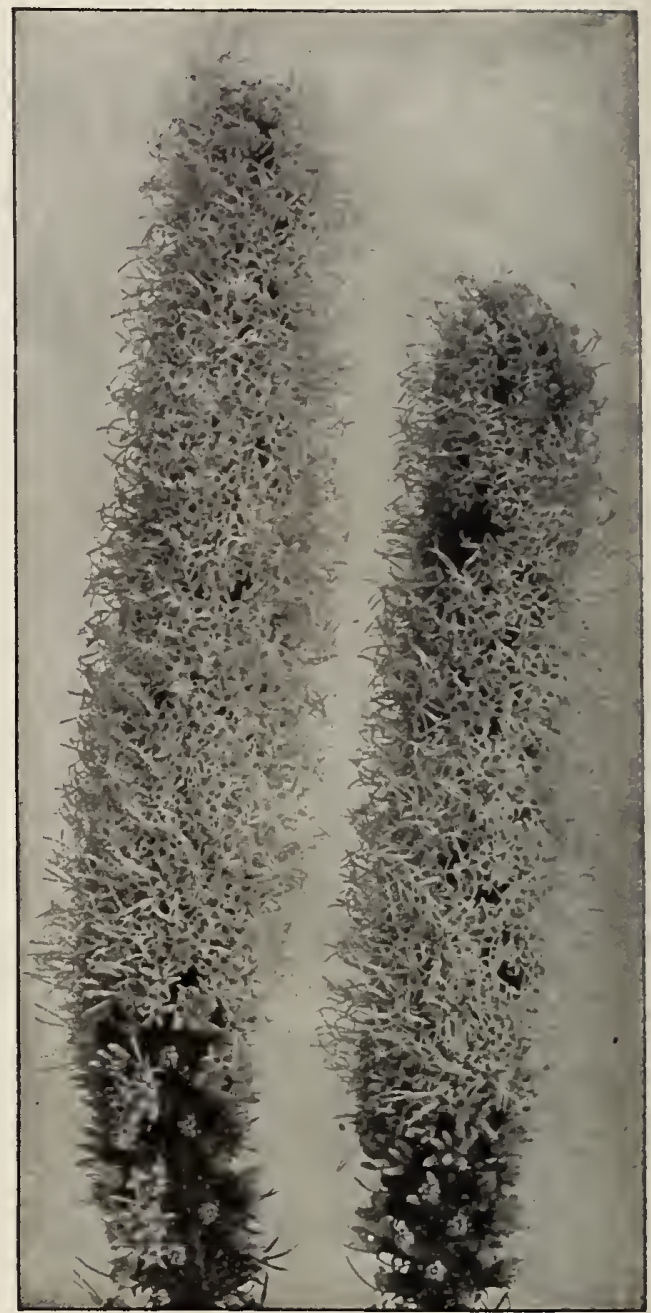

Liatris pycnostachya (see page 37 )

\section{Hollyhocks}

Have you ever noticed that painters ehoose single Hollyhoeks as subjeets for floral paintings oftener than any other flower. We suppose the reason for this is that artists have a keener appreciation of beauty than other people, and recognize that the common, and we fear sometimes despiscd, single Hollyhock, is one of the most stately, pieturesque and bcautiful plants in the world. Nothing can be morc effeetive than a large group or mass of single Hollyhocks, and onee planted they will literally take eare of themselves, even if planted in the grass. We know of patehes that have not been eultivated or disturbed in any way for twenty years. We are determined to have single Hollyhocks for our landscape gardening work, so we colleeted seed from old-fashioned (they will soon be new-fashioned) gardens and had thousands of plants grown for our eustomers. Some people think double Hollyhoeks are more beautiful than single. They are mistaken, although the doubles are bcautiful, but inclined to be top-heavy, often need staking and are liable to disease. Hollyhoeks planted in the fall will bloom well the following summer.

\section{SPECIAL OFFER OF HOLLYHOCKS}

Best Large-flowered, Single, all colors, mixed...\$1 $25 \quad$\begin{tabular}{cc} 
Per doz. & 100 \\
\hline 7 & 00
\end{tabular} Best Large-flowered, Double, mixed eolors...... 125800 Chater's Famous Strain. Best double grown.

In separate eolors..................... $150 \quad 1000$

New Allegheny. Immense semi-doublc flowers,

with fringed edges; very beautiful. . Each, 150... I $150 \quad 1000$

Our Hollyhocks are free from disease, and to ensure this we are having them grown in Ohio in soil whieh is cntirely free from the Holly hock disease. 


\section{Heliopsis Pitcheriana}

A desirable hardy herbaceous plant, growing from 2 to 3 feet high; a perpetual bloomer, beginning to flower early in the season, and continuing in bloom the entire summer. The flowers are of a beautiful deep golden yellow color, about 2 inches in diameter, of very thick texture, and are very graceful for cutting. 15 cts. each, $\$ 1.25$ per doz., $\$ 6$ per 100 .

\section{Festuca glauca}

A dwarf grass with very distinct blue foliage. Does not grow over 8 or 10 inches high, and is very effective. 15 cts. each, $\$ 1.50$ per doz

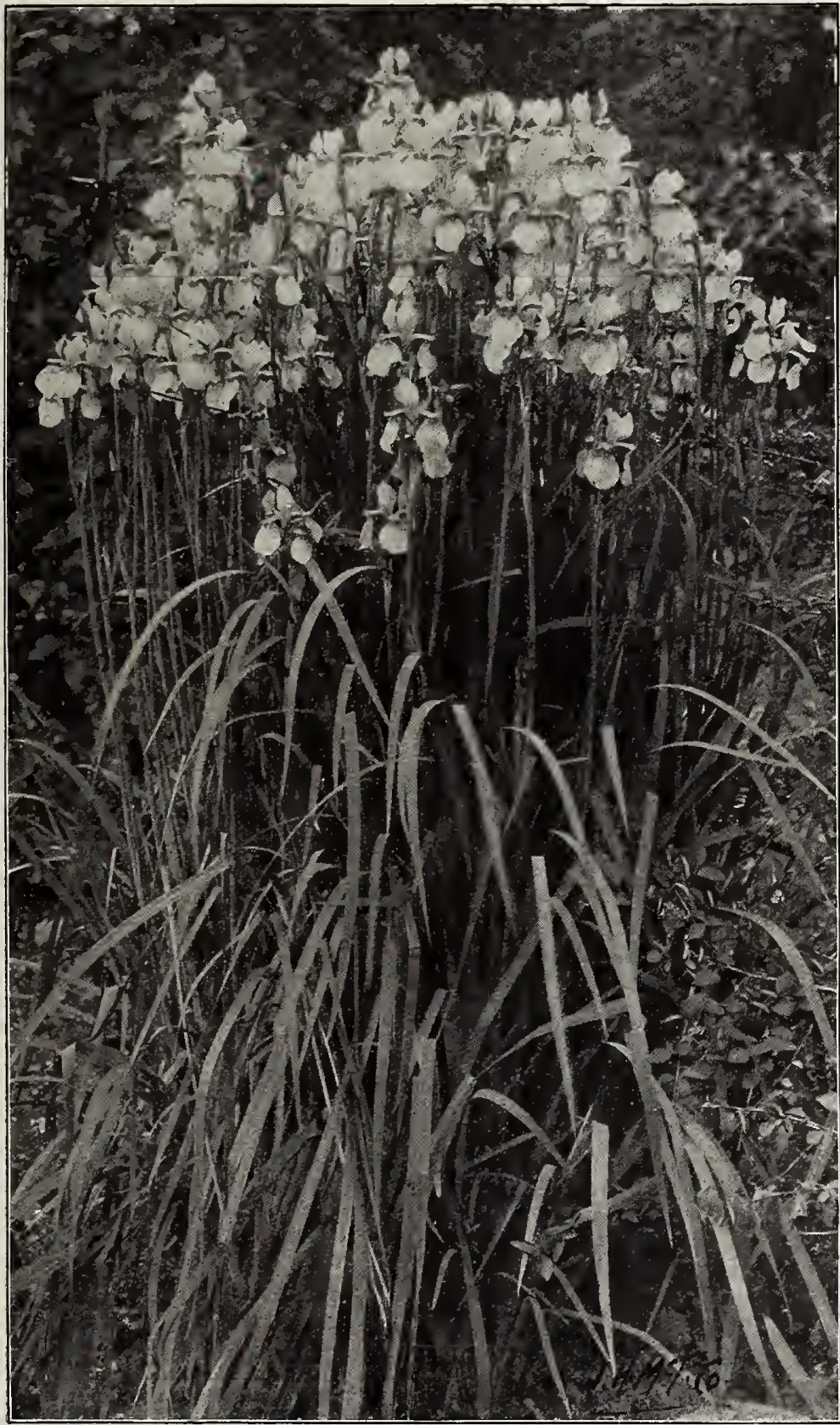

Iris tectorum

\section{Lily-of-the-Valley}

We have a small stock of American-grown Lily-of-the-Valley pips which are suitable for planting outdoors. They are thoroughly hardy and will produce a profusion of flowers early in spring. 35 ets. per doz., $\$ 1.50$ per 100

\section{Two Useful Irises}

TECTORUM. This is a beautiful white Iris, resembling $I$. Sibirica in habit and blooming at the same time-early in June. It is extremely vigorous and hardy, and very valuable either for the garden or for naturalizing on the edge of ponds or streams. Thrives in shade. $10 \mathrm{cts}$. each, $\$ 1$ per doz., $\$ 5$ per 100 .

SIBIRICA SANGUINEA. This is the best of the Siberian Irises, and is extremely desirable in every respect. The brilliant blue flowers are freely produced. The plant grows with great vigor and is perfectly hardy. Splendid for the garden, and nothing finer for naturalizing. 10c. each, 75 c. per doz., $\$ 5$ per 100 .

\section{Leontopodium alpinum}

(Edelweiss, or Alpine Snowflower)

Well known to tourists who have traveled in Switzerland. It is a hardy plant, and well worth a trial. It should be grown either on the rockery or in welldrained, sandy soil. $15 \mathrm{cts}$. each, $\$ 1.50 \mathrm{pcr}$ doz.

\section{Saponaria ocymoides splendens}

A charming creeping plant, even prettier, than the creeping Phloxes. It is quite as free-flowering, and piles itself up in masses that are lovely beyond description; beautiful bright pink flowers produced in June. One really good thing that should be in every garden. Pot-grown plants, 15 cts. each, $\$ 1.50$ per doz.

\section{Liatris pycnostachya}

The popular name of this striking plant is Kansas Gay Feather. Nothing can be planted that will attract more attention on account of its very unusual appearance; but it is very beautiful as well as odd. It blooms in midsummer and throws up long, narrow spikes of rich purple flowers, which last a long time. A peculiarity of this plant is its great attraction for butterflies; when in bloom it is always surrounded by them. See illustration on page 32 . 15 cts. each, $\$ 1.50$ per doz., $\$ 8$ per 100 .

\section{Lychnis splendens, Double Red} (Ragged Robin)

Forms a dense tuft of evergreen foliage, and in June it sends up tall spikes of handsome double, deep red flowers of exquisite fragrance, which remain in perfection six weeks. $15 \mathrm{cts}$. cach, $\$ 1.50$ per doz.

\section{Tufted Pansies, or Bedding Violas}

The tufted Pansies are hybrids of Pansies and Viola cornuta, and are quite distinct from Pansies in habit and coloring, and we think far more beautiful. The flowers are smaller, but unique in coloring, and the plants spread from the roots like a violet, making them true perennials. They are perfectly hardy, enduring the extremely cold weather of 1911-12 in an open border without protection. They are immensely popular in England and Scotland, where they are generally used for bedding and table decorations, and nothing can be more charming for either purpose. We have always admired these flowers in England, but were not certain that they would thrive in this climate, but after testing them a year in our garden we are convinced that they will do as well here as they do abroad. We have had a splendid lot of plants grown from the best collections in Scotland. They can be planted in the summer, fall or spring. In separate colors or mixed. $10 \mathrm{cts}$. each, $\$ 1$ per doz., \$6 per 100 . 


\section{Mertensia Virginica (Blue Bells)}

An carly spring-flowering plant, growing about 1 to $1 \frac{1}{2}$ feet high, with drooping panicles of handsone light blue flowers, fading to clcar pink. One of the most interesting of our native spring flowers. May and June. $15 \mathrm{cts}$. each, $\$ 1.50$ per doz.

\section{Oriental Poppies}

I remember very well the first time I saw an Oriental Poppy. I was a boy then, and it excited me wonderfully, and I thought it the most renarkable flower in the world; and now, after twenty-five years have gone by and I have seen almost all the known flowers of the world, I am still of the opinion that it is mighty fine, striking and effective, and I have taken the trouble to gather and have grown a collection of several varieties. The foliage of Oriental I'oppies dies away in the summer, and many think they are dead, but they will start into growth again in the fall. They are rather hard to establish, but, once established, prove the most persistent perennial.

Brigntness. Kich, glowing salmon. Very large flowers.

Lady Roscoe. Soft salmon-red flowers, borne on long stems.

Masterpiece. Enormous flowers; silvery llush-pink.

Trilby. Brilliant red; finest of all but not very hardy.

Silberblick. Salmon-red with white spots.

Mrs. Perry. Apricot-orange: distinct and beautiful. The flowers are borne on long steins: fine for cutting.

Queen Alexandra. Soft sa`iny salmon-pink with handsome black blotehes.

Cerise Beauty. Cerise-pink, blood-crimson center and glittering black blotches at base of petals.

Diana. Soft shade of salmon-scarlet, with black blotches.

Royal Scarlet. Glowing orange-scarlet flowers, with black blotches; very tall.

Mrs. Marsh. Scarlet, flaked white. A very brilliant Poppy, carried on a long, stout stem; fine as a cut-flower.

Prices: Any of the above named varieties, 20 cts. each, $\$ 2$ per doz., \$15 per 100. Mixed varieties, 15 ets. each, $\$ 1.50$ per doz., \$10 per 100.

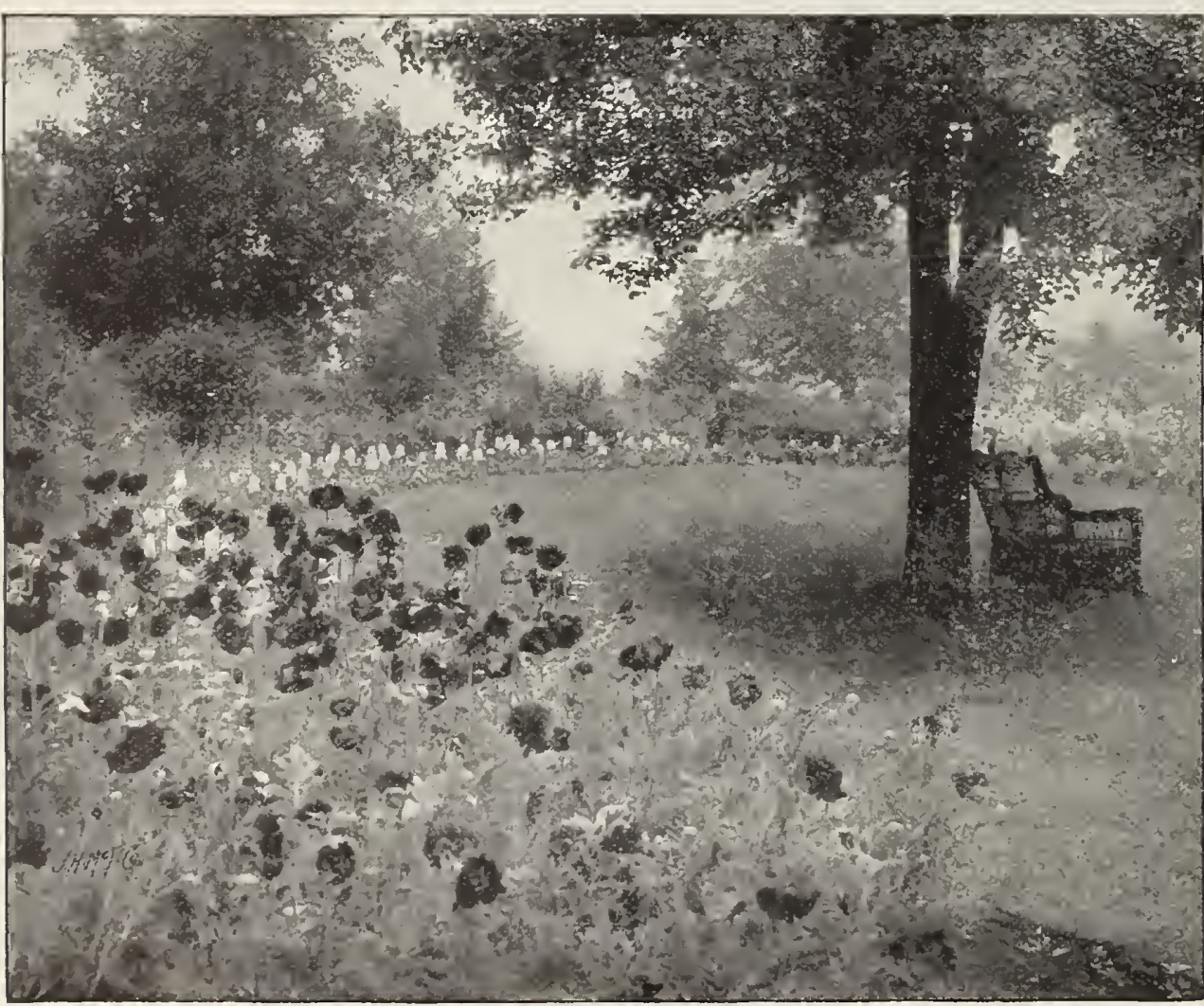

Oriental Poppies

\section{Vinca minor aurea}

(Hardy Variegated Periwinkle)

A pretty, grolden variegated form of the hardy Vinca, which is so much used as a ground-cover, especially in shaded places, where grass will not grow, and for which purpose this new varicty is a valuable addition, also for use in window-boxes during the winter months in connection with boxwoods and other crergreen plauts. Mr. IIm. Falconer, of Pittsburg, one of our best authoritics on lardy plants, says:"It is very beautiful, and I an satisfied that the variety will find an appreciative place among hardy plants." 20 ets. each, $\$ 2$ per doz.

\section{Hemerocallis, Queen of May}

This beautiful Hemerocallis originated as the result of a cross of $H$. flava major and $H$. aurantiaca major. The plant has the habit of the father, $I$. aurantiaca major, with the size and the same beautiful orange-color; but from the mother it has alsolute hardiness. It produces twelve to eighteen flowers on stems 5 to 6 feret high, and blooms from May until August. A noble plant. 50c. each.

\section{Saxifraga cordifolia}

This, the only Saxifraga, or Rockfoil, that is hardy in this climate, is distinguished by its large, handsome, shining foliage, and its dense panicles of lovely pink flowers which are produced very early in the spring. 20 cts. cach, $\$ 2$ per doz.

\section{Hardy English Ivies}

We have a fine stock of pot-grown plants suitable for carly fall or spring planting. These Ivies are hardy if planted against a north wall. 25 cts, each, $\$ 2.50$ per doz., $\$ 16$ per 100

\section{Southernwood}

Artemisia Abrotanum (Southernwood, or "Old MIan"). 15 cts. each, $\$ 1.50$ per doz.

Artemisia stelleriana. A trailing species with handsome silvery gray foliage; 6 inches high. 10 cts. each, s1 per doz.

\section{Wallflowers}

The old favorite fragrant Wallflower. Mixed eolors, including vellow, l,rown, etc. $15 \mathrm{cts}$. each, $\$ 1.50$ per doz., $\$ 10$ per 100 .

\section{Cerastium}

(Snow-in-Summer)

Tomentosum. A desirable lowgrowing plant witl silvery foliage, suitable for the rockery, or for carpeting dry, sumny spots. such as covering graves or sterp banks. Its attractive white flowers are freely produced in spring and carly sunmer. 15 cts. each, \$1.50 per doz., \$t per 100.

Biebersteinii. Sinilar to $C$, tomenlosum, but the flowers are very nuch nore beautiful. Tho plant is dwarf and covers the ground with a mat of silvery foliage which is almost evergreen. The starry flowers are white and extremely beautiful. They are produced frcely in June. The plant is for the rockery, covering dry banks or edging borders. $15 \mathrm{c}$ each, \$1.25 per doz., \$8 per 100 . 


\section{Platycodon}

Mariesi. A valuable dwarf varicty, bearing blue bellshaped flowers nearly 3 inches across, for a long season in late sun'mer and early autumn. One of the finest of border plants. The unopened buds are nearly as beautiful as the flowers themselves, and are particularly interesting in their peculiar shape. Extremely effective when planted in groups. $15 \mathrm{cts}$. each, $\$ 1.50$ per doz., $\$ 10$ per 100 .

Mariesi nana. The Platy codon, or Wahlenbergia, has been for inany years one of the most popular hardy plants, and deservedly so. This new variety is a decided improvement, as the plants are dwarfer and more compact, and never fall over. Beautiful white or blue bell-shaped flowers produced in the greatest profusion. This new plant is to be highly commended. Price of either white or blue variety, $15 \mathrm{cts}$. each, $\$ 1.50$ per doz., $\$ 10$ per 100 .

\section{Polygonum cuspidatum}

A magnificent plant for producing bold masses of foliage, growing 8 feet high in good soil. Numerous fragrant white spirea-like flowers issue from the axils of the leaves. A stately plant for large flower-borders, shrubberies, wild gardens, banks of streams and ponds and for growing beneath large trees. 15 cts. each, $\$ 1$ per doz., $\$ 6$ per 100 .

\section{Pyrethrums}

The Pyrethrums are so simply and easily cultivated that they may be recommended to all who possess a garden, whether small or large. They are perfectly hardy and absolutely invaluable for cut-flowers through the summer and autumn months. The flowers are bright and elegantly borne on long stems; most convenient for vase-decoration. In form the double varieties are somewhat aster- or chrysanthemum-like, and as their chief beauty is in the months of May and June, they may well be designated Spring Chrysanthemums. possessing the advantage over the chrysanthemums of being able to withstand the severest wintel without protection. The single-flowered varieties are veritable colored marguerites and possess a range of color and hardiness that marguerites might envy in vain. Nothing can surpass the Pyrethrum for profusion of flowers in the season; flowers succeed flowers without stint, and the blossoms are not injured by storm or sun. Their position should be in the border or in beds. The plants may, with advantage, be cut down after June, which will keep up a greater succession of bloom through the autumn. Pyrethrums grow freely in any ordinary garden soil; a good rich loam suits them, perhaps, best. and in order to secure size, brilliancy and number of flowers, plenty of ordinary well-rotted manure may be may be given when they are in bud in the dry summer weather. A mulching may be applied in dry localities with advantage. The older varieties have been greatly improved upon during the past ten or fifteen years, which is the period during which Kelway \& Son have made them a specialty, and the refined shape and brilliant or soft shades of the newer sorts have caused the Pyrethrum to become deservedly popular. We offer a splendid lot of plants of the choiccst single varieties grown from Kelway's famous strains.

All Colors Mixed. 15 cts. each, $\$ 1.50$ per doz., $\$ 9$ pcr 100.

\section{Rudbeckia, "Golden Glow"}

This hardy plant of recent introduction is entitled to rank with single hollyhocks for picturesqueness. In good soil it grows from 8 to 10 feet high, branches freely, and for two months in midsummer is literally covered with its large, bright yellow, double flowers. As a garden or lawn plant it is extremely decorative, and equally so as a cut-flower, and very lasting. We have used this a great deal in our landscape work, and have found a large circular group of it surrounded by the dwarfer Rudbeckia speciosa extremely effective. 10 cts. each, $\$ 1$ per doz., $\$ 7$ per 100

\section{Hieracium aurantiacum (Hawkweed)}

A low-growing, rapid-spreading plant, best adapted for dry, sandy spots or for covering steep slopes. The flowers are borne in flat heads and are of a bright orange-red. $15 \mathrm{cts}$. each, $\$ 1$ per doz., $\$ 6$ per 100 .

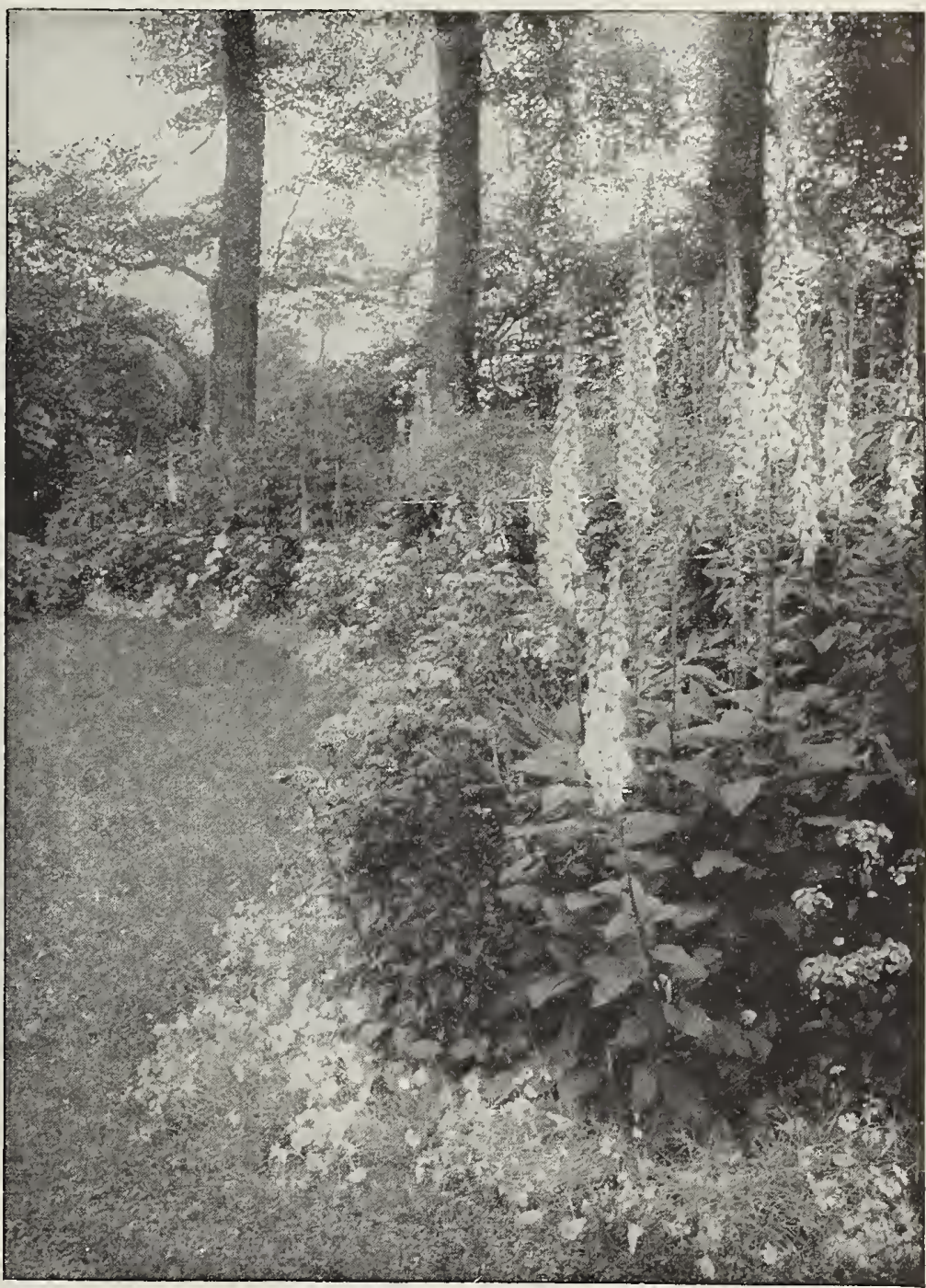

Foxglove (Digitalis). See page 35

\section{Thalictrum aquilegifolium}

This is undoubtedly one of the most desirable hardy plants in cultivation. Its fine habit, beautiful foliage and masses of lovely flowers, varying from white to purple through all intermediate shades, make it one of the most handsome things that can be planted. A graceful plant of much charm and distinction. Height 2 to 3 feet: blooms in May and June. $15 \mathrm{cts}$. each, $\$ 1.50$ per doz., $\$ 10$ per 100 .

\section{Single Violets}

In the varieties offered below, the Single Violets have been brought to such a high point of excellence that they are in equal favor with the double sorts, and, being much easier to grow and free from disease, we strongly recommend the amateur to confine himself to this class. By the use of a coldframe a fine crop of flowers can be had in the spring and in the fall.

10 ets. each, $\$ 1$ per doz., \$6 per 100

California. The variety so popular in California. This is one of the best varieties.

Princess of Wales. A grand variety; very large flowers.

\section{Hydrangea scandens}

This is the true climbing Hydrangea, one of the rarest and most difficult vines to obtain. We have succeeded in getting a small stock from Japan. It is of slow growth, but a plant will eventually cover the end of a house and is wonderfully beautiful when in bloom. Strong plants, 75 cts. each. 


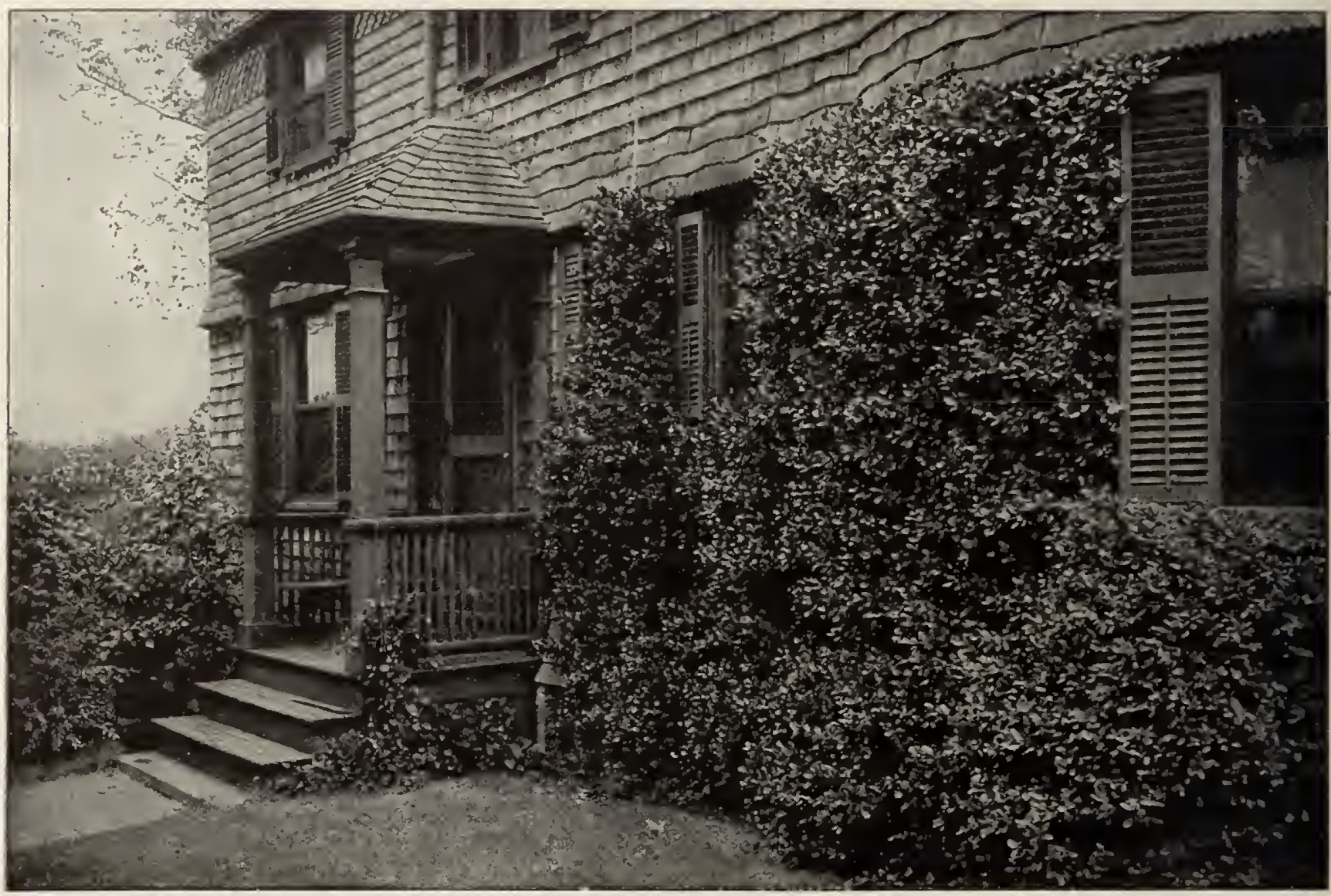

Euonymus radicans vegetus

\section{Hardy Climbing Plants}

\section{ACTINIDIA arguta}

AKEBIA quinata.

AMPELOPSIS Veitchii

Extra strong pot-grown plants.

Quinquefolia (Virginia Creeper).

ARISTOLOCHIA Sipho (Dutehman's Pipe)

Extra strong...............

BERCHEMIA racemosa.

BIGNONIA radicans (Native Trumpet

Cre -per) Orange-red...................

Grandiflora (Chinese Trumpet Creeper

Madam Galen. Dark red; free bloomer

CELASTRUS scandens (Bitter Sweet).

paniculata. From Japan. Very handsome, vigorous vine, with bright elean

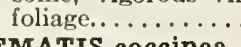

Henryi. Best large-flowered; white.

Vitalba.

Jackmani

Extra large.

Paniculata. New; extra-strong plants.

Crispa

Flammula

Virginiana

DOLICHOS Japonicus (Japanese Hardy Bean). The fastest-growing vine in eultivation.

EUONYMUS radicans vegetus. A most beautiful cverereen vine of vigorous growth and perfeet hardiness. Clings to stone or briek. Most valuable introduetion of reeent years. Small plants. .
Each Per doz.

$\$ 0 \quad 50 \$ 500$

$25 \quad 250$

$\begin{array}{lllll}20 & 1 & 75 & \$ 12 & 00\end{array}$

$35 \quad 350$

$20 \quad 200$

$\begin{array}{lll}50 & 5 & 00\end{array}$

$100 \quad 1000$

$\begin{array}{lll}25 & 250\end{array}$

$25 \quad 250$

$30 \quad 300$

$\begin{array}{lll}35 & 3 & 25\end{array}$

$35 \quad 350$

$25 \quad 250$

$40 \quad 400$

$25 \quad 200$

$50 \quad 500$

$25 \quad 200$

$\begin{array}{lll}50 & 5 & 00\end{array}$

$\begin{array}{lll}25 & 2 & 50\end{array}$

$\begin{array}{lll}25 & 2 & 50 \\ 25 & 2 & 00\end{array}$

$25 \quad 250$

$25 \quad 250$

1400

1600

1600

1500

$50 \quad 500$

$50 \quad 500$
EDONYMUS radicans. A splendid ever- Each Per doz.

100 green vine of slow growth and elegant rieh green foliage. In Erie we saw the walls of a stone house eovered with this vine. It was the finest vine effeet we have ever seen on a house and just as fine in winter as it

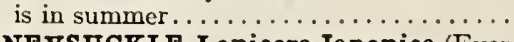

HONE YSUCKLE, Lonicera Japonica (Evergleen), Halliana, Brachypoda, aureoreticulata (Golden), 2 yrs. or pot-grown.

Heckrotti. A superb and searee sort; undoubtedly the finest Honeysuekle in eultivation.

L YCIUM Chinense (Matrimony Vine)... MENISPERMUM Canadense (Moonseed). PERIPLOCA Græca (Silk Vine).

POL YGONUM Baldschuanicum. A new and vigorous-growing climber that is attraeting a great deal of attention in England. Very free-flowering; the small branchlets bear large panicles of pure white flowers.

VITIS AFstivalis (American Wild Grape).

Riparia (American Wild Grape).

Odorata (Sweet-secnted Wild Grape). Fratgrant...

Variegata. Beautiful variegated foliage.. WISTARIA Sinensis. Purple.

Sinensis alba. White

Multijuga (Japanese Wistaria). A superb variety, with raccmes of flowers often 3 feet long.

Multijuga alba. White-flowered.......... Frutescens. Our mative Wistaria; flowers in the summer time.

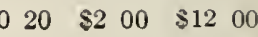

$20 \quad 200 \quad 1400$

50

$20 \quad 200$

$25 \quad 250$

$40 \quad 400$

50

20200

$15 \quad 150$

1000

$25 \quad 250$

$25 \quad 250$

30300

$50 \quad 500$

1700

3000

$\begin{array}{lll}30 & 3 & 00\end{array}$

$30 \quad 300$

$25 \quad 250$ 


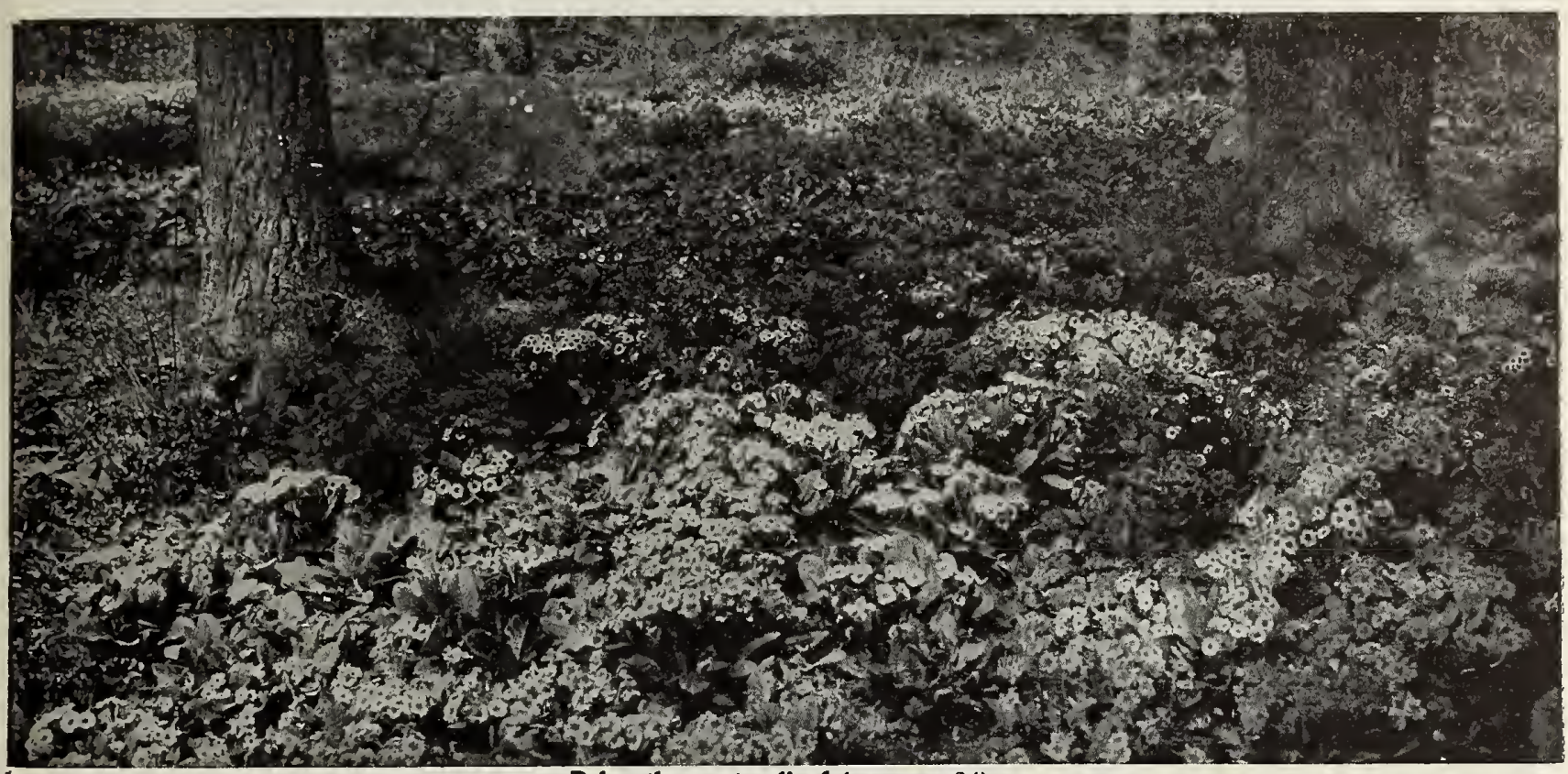

Polyanthus naturalized (see page 34 )

\section{HARDY PLANTS (Herbaceous Perennials)}

Until hardy plants come into general use we cannot hope for artistic, interesting and beautiful gardens in this country. People of taste and culture are realizing the ugliness of the stereotyped bedding with lines of color, and will no longer allow their lawns to be daubed with a flower garden like a colored lithograph, although many of our public parks are still guilty of this atrocious work. With the material offered in this list, the most beautiful and interesting gardens are to be made, gardens that increase in interest and beauty year after year; gardens that change their aspect with every change of season. To make a garden with hardy plants and shrubs requires far more taste and knowledge than it does to make one with the few varieties of bedding plants generally used, but the majority of gardeners do not have this knowledge, and have no idea of proper arrangement. But the garden of hardy plants has this advantage: the individual beauty of the plants themselves is so great that a garden cannot fail to be interesting and lovely, no matter how badly arranged, if the cultural skill is sufficient to bring them to perfection. One of the most effective ways of using hardy plants is to plant in a wide border in front of a hedge or shrubbery. The trouble with this arrangement is that the roots of shrubs or hedge get into the border and rob the plants of a large share of their food. This can easily be prevented by placing a sunken wall of concrete between the hedge or shrubbery and border. This wall need be only 2 feet deep and 4 inches thick, and is inexpensively constructed of gravel and cement. Another very effective arrangement is two broad borders through the vegetable garden, with a broad grass walk between them. The effeet will be enhanced by building trellises back of the borders and covering them with climbing roses or flowering vines.

Cultivation is of the simplest: beginning with any good garden soil, deeply dig it and enrich it with old rotted stable manure. The best time to plant hardy perennials is when they are just starting into growth in the spring or early in the fall. The soil should be comparatively dry when plants are set out. A void wet planting. Do not make the mistake of planting too thickly. The nearest approach to a rule which may be followed in planting is to set out plants which grow to a height of 2 fcet or less, 12 inches apart, and all taller onehalf their height. For example, Aquilegias and Coleopsis which grow 2 fcet high may be planted 12 inches apart, while Delphinium formosum and Japanese Iris which grow 3 feet high, should be 18 inches apart.

During the summer, the soil about the plants should be frequently stirred and wceds kept down. During hot, dry weather, or when it is not convenient to watrr, a mulch of any loose, light material is very beneficial in retaining the moisture and preventing the ground from baking; grass clippings from the lawn are excellent material for this purpose.

About the middle of November, or later, when all soft growth has been killed and the plants are thoroughly ripence, the old hardwooded stems should be removed and burned. Then cover the plants with 2 or 3 inches, not more, of loose strawy stable manure. Care must be taken, however, not to cover the foliage of evergreen plants such as Phlox subulata, Hardy Pinks and Candytuft, as such a covering would cause the foliage to rot and kill the plants.

Most hardy plants which flower during the spring or early summer months, such as Peonies, Anthericums, Dielytras, Funkias, German Iris, etc., are better left undivided and undisturbed for several years, but they should be given a liberal dressing of stable manure or other fertilizer every spring. The late-flowering plants, like Phloxes, Helianthus, Rudbeckias, Asters, Boltonias, Physostegias, etc., are better for being replanted at least every two years. The Japanese Anemones are an cxception; they shou'd be allowed to remain undisturbed for several years.

\section{SPECIAL OFFERS OF HARDY PLANTS IN VARIETY}

The plants in the following collcctions will be of the best and most desirable varieties and the plants of the best quality, but in every instance the selection of varicties is to be made by us; but if purchasers will state the things they have, or don't wish, these will nct be included in the selection. Sometimes people write asking for a list of the plants contained in these collcctions. This can not be given, so please save us the unpleasantness of refusing by not asking for it.

Offer No. 1 of Hardy Plants. Twenty-five first-class plants in variety for

Offer No. 2 of Hardy Plants. Fifty first-class plants in variety for

Offer No. 3 of Hardy Plants. One hundred first-class plants in varied a ssortment of best species and varieties for

Offer No. 4. Five hundred Hardy Plants, same as above, but in larger variety, for

Offer No. 5. One thousand Hardy Plants, same as above, but in much larger variety, for

In the following list height and time of blooming are indicated as follows. Figures following the letter $H$ indicate height in feet figures following the letter $\mathrm{F}$ indicate the number of the month or months the plants bloom in. This is only approximate, as height and time of flowering vary considerably with soils, climates and seasons.

Plants suitable for growing in the shade are marked *. For growing in partial shade are marked $\dagger$.

Prices quoted are tor not less than half the quantities named, but single plants will be furnished at following low rates: Plants at $\$ 1$ or less per doz., 10 cts. each; plants at $\$ 1.25$ and $\$ 1.50$ per doz., 15 ets. each; plants at $\$ 1.75$ and $\$ 2$ per doz., 20 ets. each; plants at $\$ 2.50$ and $\$ 3$ per doz., 25 cts. each. 


\section{HARDY HERBACEOUS PERENNIAL PLANTS, continued}

ACANTHUS mollis. A striking foliage plant...... Per doz

*ACONITUM Napellus (Monkshoorl). Beautiful but poisonous plant with blue flowers........... 250

ACHILlEA Ptarmica fi. pl. One of the most useful plants; numerous and dense masses of white

flowers; fine for cutting. H 1 to $2, \mathrm{~F} 6$ to $10 \ldots \ldots$.

fusion for a long season: little known in this country but very popular in England. H 1 to 3 , $\mathrm{F}+$ to $10 \ldots \ldots \ldots \ldots \ldots \ldots \ldots \ldots \ldots \ldots \ldots \ldots \ldots \ldots$.

gyptica. Sulphur-vellow flowers; silvery gray

"The Pearl." An improvement of Ptarmica fl. pl.

$\mathrm{H} 2, \mathrm{~F} 6$ to $10 \ldots \ldots \ldots \ldots \ldots \ldots \ldots \ldots \ldots \ldots$.

ETHIONEMA grandiflora. Flowers in rosy racemes $\mathrm{H} 2, \mathrm{~F} 5$ to 8 . .

AGROSTEMMA coronaria. Perdoz, 100 Beautiful rich erinson flow-

ers. H $1 \frac{1}{1}, \mathrm{~F} 7 \ldots \ldots \ldots \ldots 125 \quad \$ 800$

Coronaria alba. Pure whitc. 125800

Coronaria atrosanguinea.

Brilliant dark crimson..... 125800

Coronaria bicolor. White and red.

800

Flos Jovis. Extremely desirable rose-tinted flowers, fine for eutting. H $1 \frac{1}{2}, \mathrm{~F} 7125$

ALSTRCEMERIA Chilensis (Chilian Lily). A tuberousrooted plant 2 feet high, with spikes of showy flowers varying from rosy white to deep orange and red, flowering from July to September. In exposed situations requires proteetion... 150

AL YSSUM saxatile compactum. Masses of golden yellow flowers. Invaluable for spring flowering. $\mathrm{H} 1$,

F 4 ........ 125800

*AMSONIA Tabernæmontana. Desirable perennial with lead-colored blue flowers. H $2, \mathrm{~F} 5$ to 6 .

150

ANEMONE Pennsylvanica. $A$ beautiful native Anemonc. Fine for naturalizing H $1 \frac{1}{2}, \mathrm{~F} 6$. . . 150

Japonica rosea. Purplish rose. H 3 to $5, \mathrm{~F} 9$ to $10 \ldots 150 \quad 800$

Japonica rosea elegans. Improved variety. H 3 to 5, F 9 to $10 \ldots \ldots \ldots \ldots \ldots$

† Japonica alba. White. H 3 to $5, \mathrm{~F} 9$ to 10. $150 \quad 1000$

Japonica, Whirlwind. New semi-double variety. White. $\mathrm{H} 3$ to $5, \mathrm{~F} 9$ to 10 . 150800

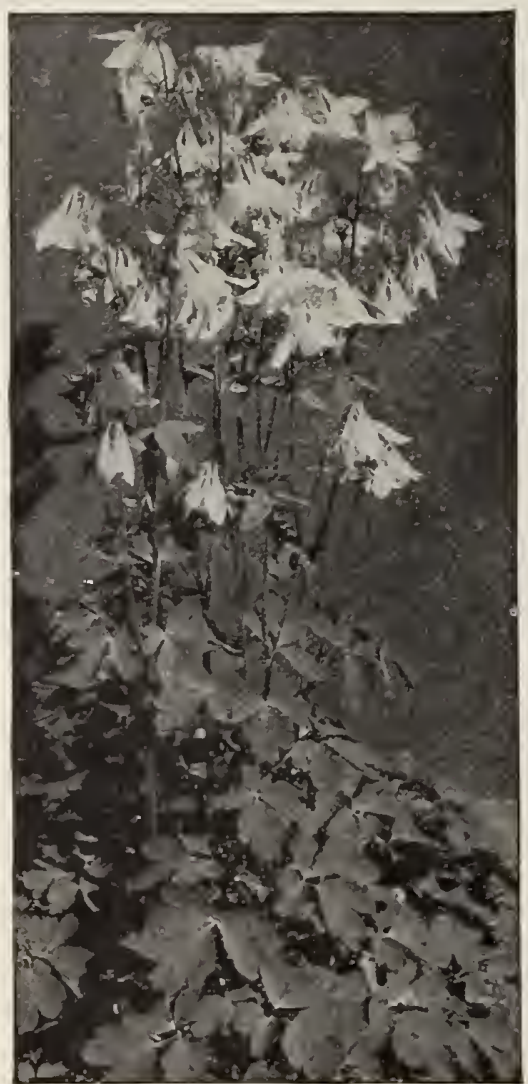

Aquilegia
A QUILEGIA corrulea (Rocky Mountain Columbine). Per doz. 100 The most beautiful of all Columbines; one of the most charming hardy flowers in eultivation.

H $1 \frac{1}{2}, F 4$ to $5 \ldots \ldots \ldots \ldots \ldots \ldots \ldots \ldots \ldots \ldots \$ 175 \$ 1000$

Corulea lutea. New; large, light vellow flowers. I 1 to $2, \mathrm{~F}+$ to $5 \ldots \ldots \ldots \ldots \ldots \ldots \ldots \ldots \ldots$. 1751000

†Chrysantha. Beautiful golden yellow flowers: blooms for two months. H 3 to $4, F 5$ to $6 \ldots \ldots 150 \quad \gamma(3)$

†Chrysantha alba. A white variety of the above.. $125 \quad 800$

†Canadensis (nativc). Red and yellow. H 1, F 5.. $150 \quad 800$

+Canadensis nana. Very dwarf; distinct and pretty

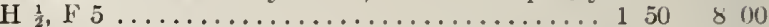

†Skinneri. Searlet, handsome and distinet. H 3 to 4 ,

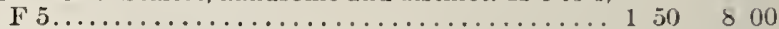

†Glandulosa. Splendid dwarf varicty, with lovely blue and white flowers................ $150 \leqslant 00$

†Jætschaui. Large yellow flowcrs, with reddish spurs $150 \quad \diamond 00$

tCalifornica. Large orangeyellow flowers.......... 150 Truncata. Searlet and yellow; dwarf, very early..... 150

Alpina superba. Blue and

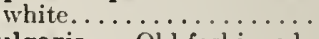

†ulgaris. Old-fashioned double Columbine........ $125 \quad$ ช 00

Sir choice Aquilegias, in six varieties, for $75 c$. or 12 plants, in 12 varieties, for $\$ 1.50$

AJUGA reptans atropur-Perdoz. 100 purea. Large spikes of purplish blue flowers in May. Valuable plant for the rockery and for carpeting the ground in shady places where grass will not grow..................

ing plant, with dense mosslike foliage; white flowers in spring; fine for roekwork. . 150

800

tARALIA. Splendid native foliage plants, growing 6 to 8 feet high; of striking effect

Cordata............... 200

Edulis. . . 200

Cachemirica..........2 00

ARABIS alpina. Forms a dense earpet, completely covered with pure white flowers in early spring. Fine for roekwork and edging............... 150

ARTEMISIA Abrotanum. (Old Man, or Southernwood). Dark green, finely. cut foliage; aromatic odor. 150

Absinthium (Worinwood)... 150

Stelleriana (Old Woman). Deeply cut silvery foliage; much used in earpet-bedding. $\mathrm{H} 18$ in......... 100

Japonica, Queen Charlotte. Large scmi-double Perdoz. 100 flowers of a lovely shade of pink............. \$1 50 \$8 00

†aponica, Lady Ardilaun. Pure white, broad. These charming Japanese Anemones a. ..................... $150 \quad 900$ most beautiful things in eultivation. They are perfeetly hardy, and in a strong, rieh and heavy soil will grow 4 to 5 feet high. They are a mass of beautiful white or pink bloom from late sumuer until heavy frosts. They should be in every garden, and on large places should be planted by the hundred. Should be planted early in Septenber or in the spring. They like a heavy soil and partial shade.

ANCHUSA "Dropmore Variety." A grand variety growing 4 to 5 feet high with lovely blue flowers throughout the season...........eaeh, 25 ets.. 250

ANTHEMIS Kelwayi. Soft, clear yellow. H $1 \frac{1}{2}, \mathrm{~F}$

HERICUM Liliastrum (St. Bruno's Lily). Pure white, fragrant, graceful, lily-like plant, preferring partial shade.

ARUNDO Donax. Splendid for making tropieal-like groups; will grow 16 feet high in rieh soil........ $300 \quad 2000$ Donax macrophylla. An improved variety with broader lcaves.............50 cts. each. .

Donax variegata. Striking variegated foliage. H 5 to $8 \ldots \ldots \ldots \ldots \ldots \ldots \ldots \ldots \ldots \ldots \ldots \ldots \ldots 25251500$

ARMERIA maritima splendens (Thrift or Sca Pink) H $1 / 4, F 5$ to 7 .

Dianthoides.

Formosa

ARRHENATHERUM bulbosum variegata. A neat and distinct new variegated grass whieh should prove very attractive in the rock-garden....... 150

ASCLEPIAS t:uberosa. Orange-searlet; one of the showiest and finest hardy plants grown. $\mathrm{H} 1$ to 2, F 7 to $9 \ldots \ldots \ldots \ldots \ldots \ldots \ldots \ldots \ldots \ldots \ldots \ldots$. 50

Incarnata. Rosy pink flowers: very desirable. $\mathrm{H}$ 2 to $3, \mathrm{~F} 7$ to $9 \ldots \ldots \ldots \ldots \ldots \ldots \ldots \ldots \ldots$ 


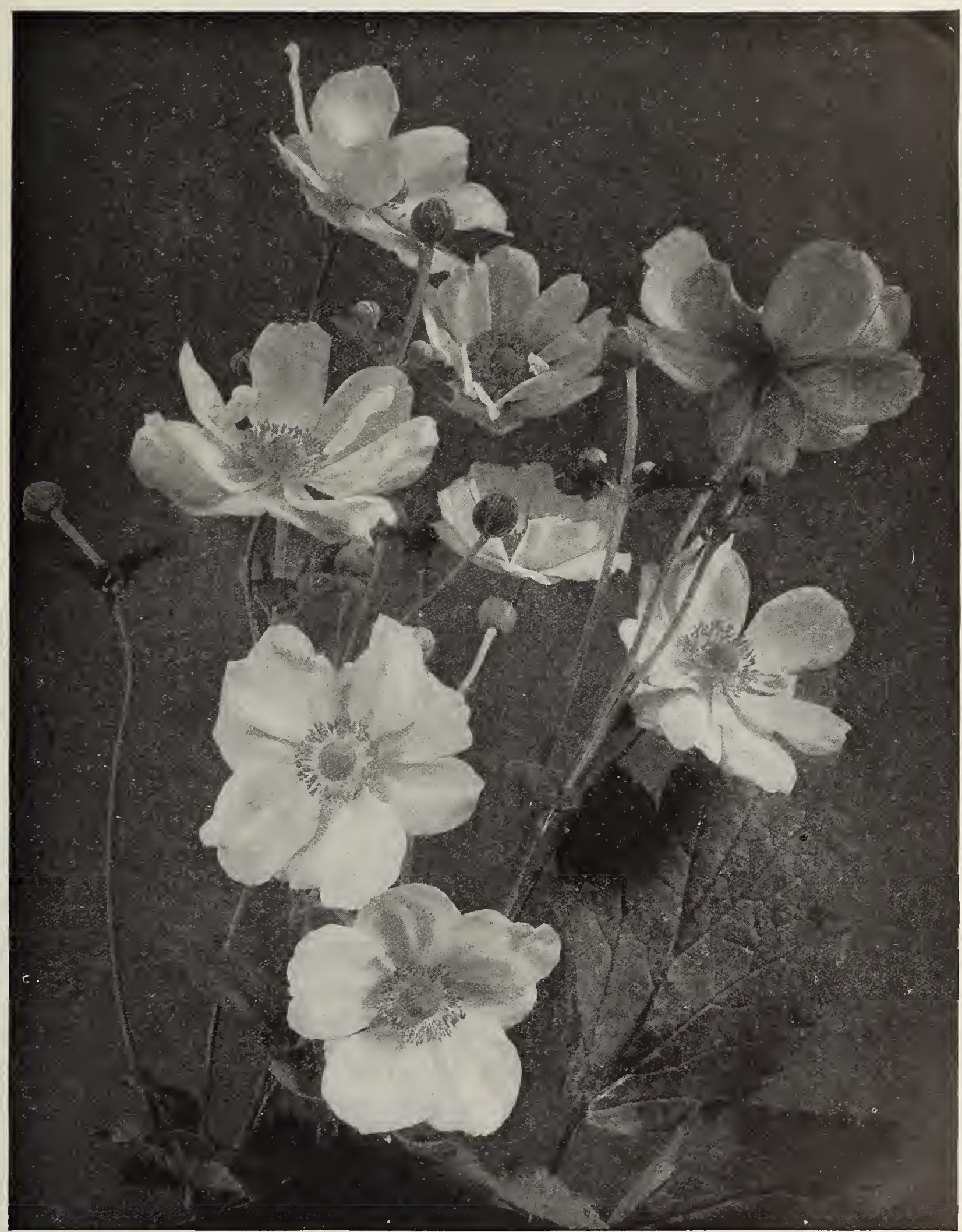

ANEMONE JAPONICA (see page 42) 
HARDY HERBACEOUS PERENNIAL PLANTS, continued

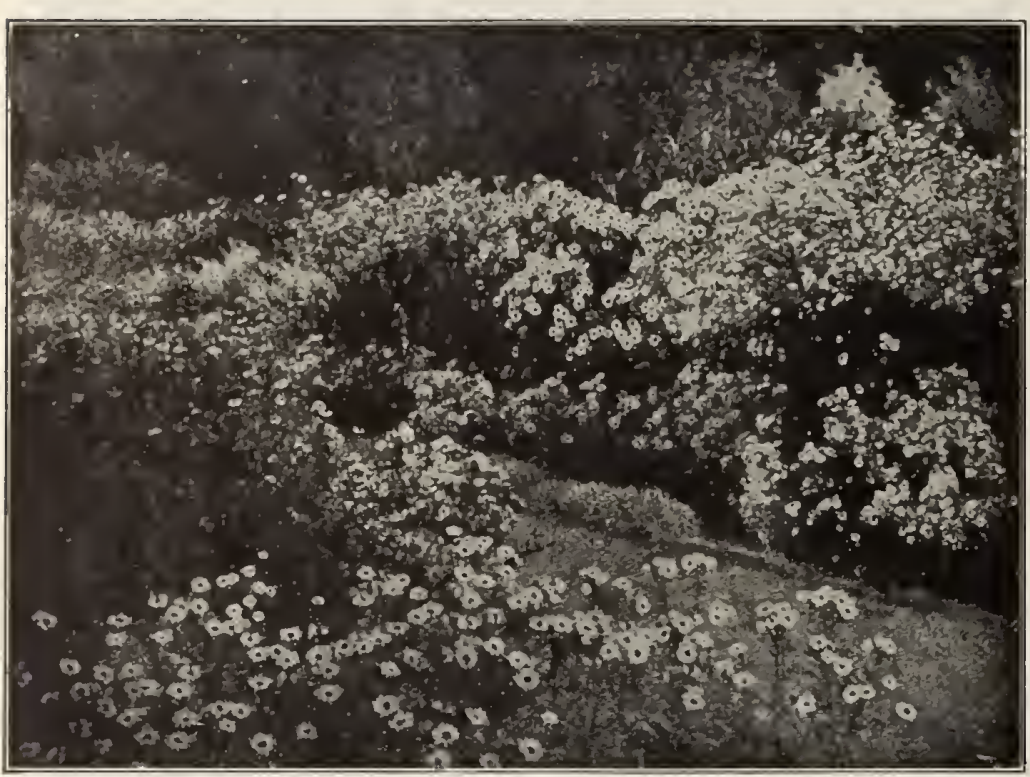

(Froin "Wood and Garden")

Hardy Asters

ASTER Novæ-Angliæ rubra. The best of the Amer- Perdoz. 100 ican "Hardy Asters"; very showy. H 3 to 4, F 9 to 10

Alpinus. Very dwarf variety with large showy purplish flowers in May and June............ 150

Alpinus alba. A variety of above............ 150

BEAUTY OF TYMARDREATH. A beautiful new

Michælmas Daisy; white flowers with golden dise changing to red.

Top Sawyer. Clear blue very fine H 4 to 5 , F 9

Turbinellus. Delieate mauve. $\mathrm{H} 2$ to $4, \mathrm{~F} 92250$

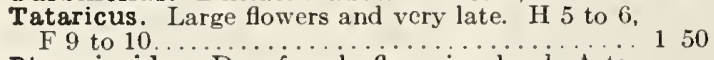

Ptarmicoides. Dwarf, early-flowering, hardy Aster blooming in July and August. Its eharming white flowers are produeed in the greatest profusion. Distinet and good

White Queen. White flowers. H $4, \mathrm{~F} 9 \ldots \ldots$

Trinervius. White, with purple and yellow dise. H $3 \frac{1}{2}$ F 8 to $9 \ldots \ldots \ldots \ldots \ldots \ldots \ldots$
Grandiflorus. Distinet in eharaeter and flower; very large flowers of a lovely violet-blue, and is the latest variety to bloom.....................

Coombe Fishacre. Fine flesh-colored native;

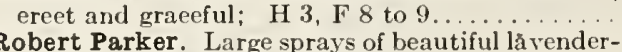

blue flowers, with yellow eenter. H 4, F $9 \ldots \ldots 250$

Novæ-Angliæ, Wm. Bowman. Large, rich rosy purple flowers, with deep golden bronze dise. Very showy. H 4 to 5, F 8 to 9 . . each, 15 cts... 150

Novæ-Angliæ, Mrs. J. F. Rayner. Large vivid erimson flowers, 2 inches in diameter; strong, ereet grower $\mathrm{H} 4$ to $5, \mathrm{~F} 8$ to 9.

Novi-Belgii, Ella. Large, delieate mauve flowers, with golden center; profuse bloomer; extra fine. 250

AUBRIETIA violacea. Valuable evergreen trailer. $\mathrm{H} 1$ to $3, \mathrm{~F} 4$ to 5 .

BAPTISIA australis.

BELLIS perennis (Double Daisy). Assorted colors. $\mathrm{H} \frac{1}{2}, \mathrm{~F} 4$ to 5

BERGAMOT. See Monarda.

BLEEDING HEART. See Dientra.

BELLIS perennis (English Daisy). Improved, largefowered variety; white and pink. ..

BOCCONIA macrocarpa

Cordata. Large, hroad, striking leaves; large plumes of white flowers; fine for subtropieal effects. H 5 to $7, F 7$ to 8

Giralda. A handsome new variety with large silvery gray foliage and bold heads of milky white flowers.

$150 \quad 1000$
BAPTISIA australis (False Indigo). Per doz. 100 Dark green, deeply eut foliage and spikes of dark blue flowers. H '2, F 6 to 7

BOLTONIA latisquama. Light pinkish blue flowers; very lovely; blooms late in fall. Highly recominended. H 3 to 4

Asteroides. Pure white; very effeetive. H 3 to $4, \mathrm{~F} 9$ to $10 \ldots \ldots$....

CALLIRHOE involucrata. Large

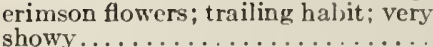

CaLIMERIS incisafolla. A graeeful little plant with finely eut foliage and the prettiest of all single white daisy flowers; blooms all summer and is distinet and fine.

$150 \$ 1000$ $150 \quad 1000$ $125 \quad b 00$

CAMPANULA (Bellflower) The Campanula genus is one of the largest and ehoieest. The varicties are all of elegant habit and should be represented in every garden.

Alliariæfolia. Graeeful spikes of long. bell-shaped white flowers. H 3, F 7.. 150

Pyramidalis. Very showy, tall variety. $\mathrm{H} 4$ to $5, \mathrm{~F} 7 \ldots \ldots \ldots 150$

Pyramidalis alba. White-flowers.

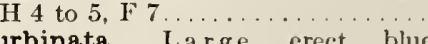

Turbinata. Large, erect, blue 175 $\begin{array}{llll}175 & 1200\end{array}$

Turbinata alba. Charming white flowers. $\mathrm{H} \frac{1}{2}$ to $1, \mathrm{~F} 7$ to $8 \ldots \ldots \ldots \ldots \ldots \ldots \ldots 1501000$ Medium (Canterbury Bells). One of the showiest and prettiest of garden plants; but, being only a bicnnial, dies after blooming. Should be planted in spring... $150 \quad 1000$

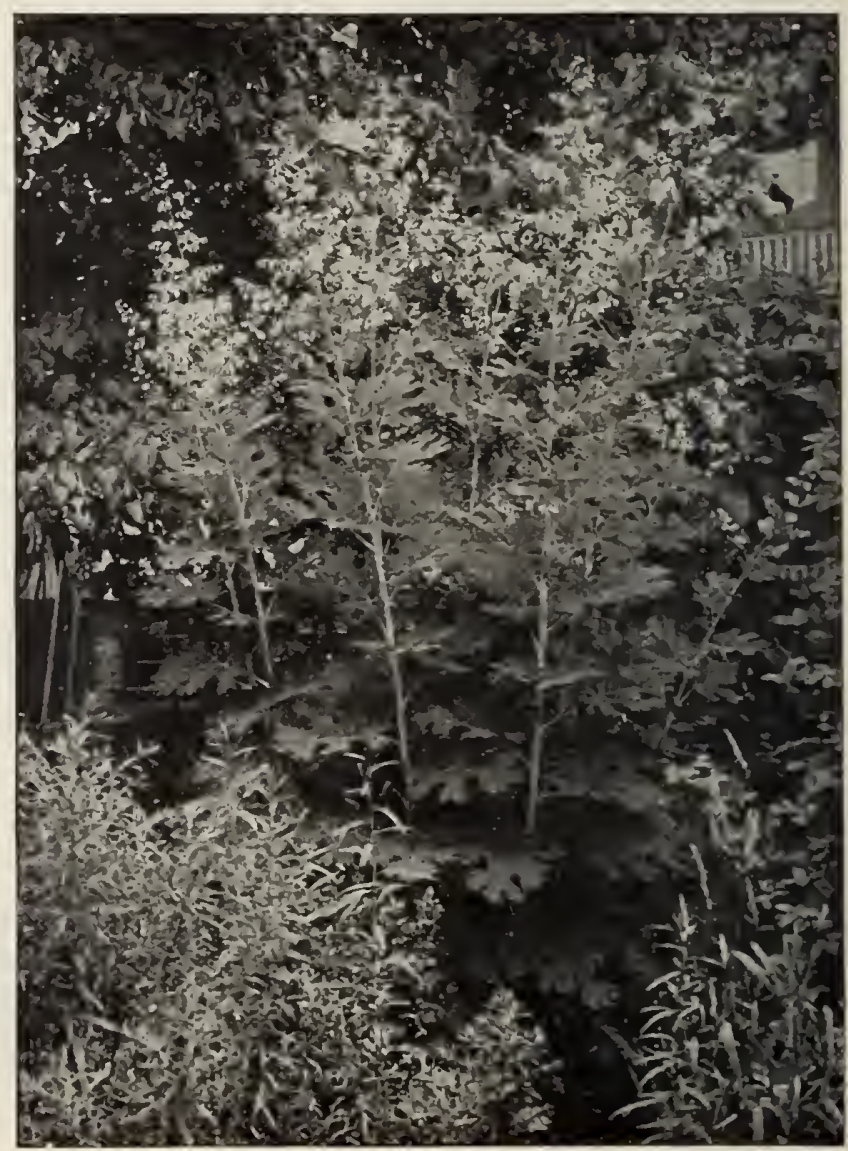


HARDY HERBACEOUS PERENNIAL PLANTS, continued

Camp an ula persicifolia. Perdoz, 100 Largc blue flowers, almost as showy as Canterbury Bells. H 2, F 6 ....

ersicifolia alba. White
flowers; a grand border plant. H 1 to $3, \mathrm{~F} 7 \ldots 150$

Grandiflora Mariesi. Large white and purple flowers; desirable..

Mariesi compacta nana. A ncw improved dwarf variety of great beauty; large white or purple flowers............... $150 \quad 1000$ Carpatica. Dwarf; light blue. H $3 / 4$, F 6....... $150 \quad 1000$ Macrantha. Large blue flowers; one of the best . . $150 \quad 1000$

Punctata. Strong, erect spikes, fine and showy; one of the best........

CAND YTUFT. See Iberis.

CANTERBURY BELLS. See Campanula Medium.

CARDINAL FLOWER. See Lobelia.

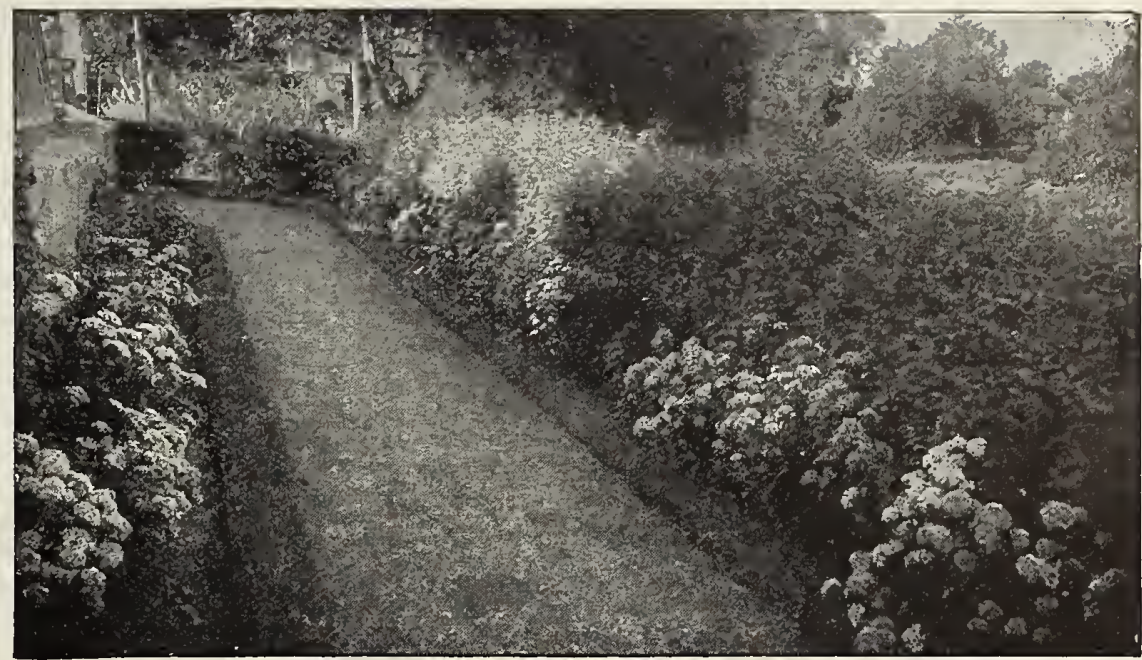

125800

CASSIA Marylandica. Handsome pinnate foliage
and numerous racemes of showy yellow flowers and numerous racemes of showy yellow flowers; $\mathrm{H} 4$ to $5, \mathrm{~F} 7$.

CENTAUREA Babylonica. Showy yellow flowers; suitable for planting in shrubberies and large borders. $\mathrm{H} 6$ to $10, \mathrm{~F} 7$

Macrocephala. Yellow; very fine. $\mathrm{H} 3$ to $5, \mathrm{~F} 7.150$

Montana (Mountain Knapweed). Blue flowers. H 2, F $6 \ldots \ldots \ldots \ldots \ldots \ldots \ldots \ldots \ldots \ldots \ldots \ldots$. 150

CERASTIUM Beibersteinei. Very dwarf plant, covered with small white flowers; very desirable for carpeting or edging borders and beds; silvery white foliage, which is very attractive throughout

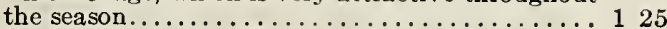

CHRYSANTHEMUM, Hardy Pompon Varieties. $\mathrm{H} 2$ to $3, \mathrm{~F} 10$ to 11

Hardy Large-flowered Varieties. These and the preceding varieties are the old-fashioned Chrysanthemums that used to be in every garden. They are perfectly hardy, and make a brave show of color late in the fall, after all other flowers are gone. $\mathrm{H} 3$ to $4, \mathrm{~F} 10$ to $11 \ldots \ldots \ldots \ldots \ldots \ldots$

Latifolium. Similar to the Maximum but much better; one of the most satisfactory of hardy plants; highly recommended; fine for cutting.

Hedge of Dianthus barbatus

DAY LILY, WHITE. See Funkia.

Yellow. See Hemerocallis.

DELPHINIUMS, Chinense. Dark blue, smallflowered; elegant and distinct dwarf species.....\$1 $50 \quad \$ 900$

Formosum. A splendid old hardy plant, with dark

intense blue flowers. $\mathrm{H} 4$ to $5, \mathrm{~F} 6$ to $7 \ldots \ldots \ldots 125$

Formosum coolestinum. New; light; of great beauty

Fine Mixed. Tall English. H 4 to $8, \mathrm{~F} 6$ to $9 \ldots \ldots$. 150

DIANTHUS barbatus (Sweet William). Improved auricula-flowered.

Latifolius atrococcineus fl. pl. (Everblooming Hybrid Sweet William). A beautiful summer bedding variety, producing masses of brilliant fiery crimson flowers throughout the entire season....

Scoticus fl. pl. (Double Scotch Pink). Desirable. H 2, F 6 to $9 \ldots \ldots \ldots \ldots \ldots \ldots \ldots \ldots \ldots \ldots \ldots 150$

Maximum. Large, single, daisy-like flowers........ 125 Maximum fllifera. A dwarf, improved form of Maximum ......................... 50

Maximum, Princess Henry. A variety with very large white flowers.................... 150

Leucanthemum (Shasta Daisy). Advertised as a California Wonder...........10 cts. each.... 100

CLEMATIS recta. Large heads of purc white flowers. Davidiana. This is an herbaceous plant instead of 250 a climber, and has beautiful blue flowers and handsome foliage; very desirable............

Integrifolia. Largc purple flowers in great profusion in July and August................ 150

COREOPSIS grandiflora. An improved variety with large, bright yellow flowers; fine for cut-flowers; one of the best hardy plants in cultivation. H 2 to $3, F 5$ to 7 .

800

800

1000

800

verticillata. Masses of small golden yellow flowers, finely cut foliage. $\mathrm{H} 2$ to $3, \mathrm{~F} 7$ to $8 \ldots \ldots \ldots \ldots 150$

CORONILLA varia. Compact sheets of beautiful pink bloom. H 1, F 5 to $10 \ldots \ldots \ldots \ldots \ldots \ldots 125$

CONVALLARIA maiais (Lily-of-the-Valley). Pips. 40

CRAMBE cordifolia. One of the finest large-leaved herbaceous plants; valuable where a striking and bold effect is required...........35 cts. each.. 350

CFPRIPEDIUM spectabile. The most beautiful hardy orchid, and one of the most lovely flowers in the world; does well in a shady location..... 350 "Her Majesty." A fine hardy white Pink.

Plumarius, Pheasant's Eye (Hardy Pink).

Plumarius semperflorens. One of the most beautiful Pinks in cultivation; blooms all season.

Deltoides. A creeping Pink of great beauty.

Juliette. White laced crimson.

†DICENTRA spectabilis (Bleeding Heart). H 1 to $2, \mathrm{~F} 4$

* Eximia. Beautiful fern-like foliage; blooms all summer. $H 3 / 4$ to $1 \frac{1}{2}, \mathrm{~F} 4$ to 8

DRACOCEPHALUM Ruyschiana. Dark violotblue; neat border plant. H $2, \mathrm{~F} 6 \ldots \ldots \ldots \ldots$

DICTAMNUS. The Dictamnus is one of the most
satisfactory hardy plants in cultivation, both on satisfactory hardy plants in cultivation, both on foliage.

Fraxinella. $\mathrm{H} 2, \mathrm{~F} 5$ to $7 \ldots \ldots \ldots \ldots \ldots \ldots \ldots, 200$

Fraxinella alba. H $2, F 7$ to $8 \ldots \ldots \ldots \ldots \ldots \ldots, 200$

†DIGITALIS purpurea (Foxglove). H 4 to 7, F 7 . 11501000

tGloxinmflora.

Maculata superba....................... $150 \quad 800$

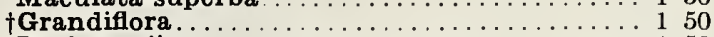

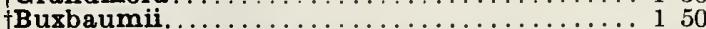

DORONICUM plantagineum excelsum. H 2 to 32501500

1000 ECHINOPS Ruthenicus. Showy thistle-like plants with globular heads of glaucus blue flowers.....2 200

EPILOBIUM angustifolium. Crimson flowers; suitable for naturalizing. H 3 to $6, \mathrm{~F} 7 \ldots \ldots \ldots 150$

ERIANTHUS Ravennæ. A splendid tall-growing grass suitable for tropical effects. H 8 to 12 , F 9

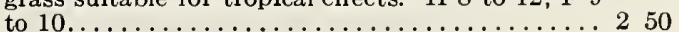

ER YNGIUM Ebeneum. (Sea Holly). Curious and

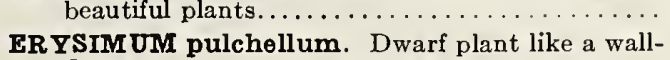

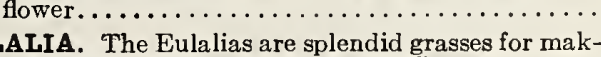
ing beds and groups for tropical effects.

Japonica variegata. H 5 to 7 .

Japonica. H'5 to 7

Gracillima. Very graceful. H 5 to 7 . 


\section{HARDY HERBACEOUS PERENNIAL PLANTS, continued}

EUPBORBIA corollata. A choice native plant with Perdoz. 100 white flowers; largely used by florists for cutflowers.

$\$ 150$ \$ $0 J$

EUPATORIUM purpureum. A splendid native plant, growing 6 to 10 feet ligh, with immense head of purplish pink flowers; fine for naturalizing along streams and ponds, and for planting among shrubbery. $F 7$ to 9 .

EVENING PRIMROSE. Scc Enothera.

*FERNS. Best hardy varieties.

$150 \& 00$

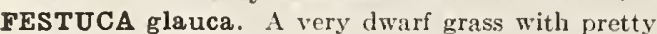
bluc foliage; fine for edging.............. $150 \quad \diamond 00$

FOXGLOVE. See Digitalis.

*FUNKIA subcordata (White Day Lily). H $1 \frac{1}{2}$, F 5

*Variegata. Variegated foliage, blue flowers, $\mathrm{H} 1$,

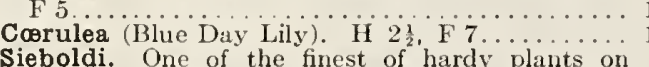

* Sieboldi. One of the finest of hardy plants on account of its splendid foliage. H 2 to 3 , F 7 to 8 . of a bright ycllow color.

* Marginata albo variegata. A very distinct variegated variety.

*Aoki, Larg glaucus grecn leaves.

Fortunei. Large glaucous green lcaves; Howers mauve.

$50 \quad 1000$

25800

25800

$\begin{array}{lll}00 \quad 1200 & 00\end{array}$ 50

$\begin{array}{lll}50 & 10 & 00\end{array}$

$125 \quad 700$

GILLENIA trifoliata. A strong-growing plant, suitable for the border or shrubbery; handsome foliage and numerous white fowers tinged pink. H 3, F 7. 200

GEUM Coccineum. Pretty border plants, growing 18 inches high and producing brilliant scarlet flowers throughout the summer.

Atrosanguineum. Orange-scarlet

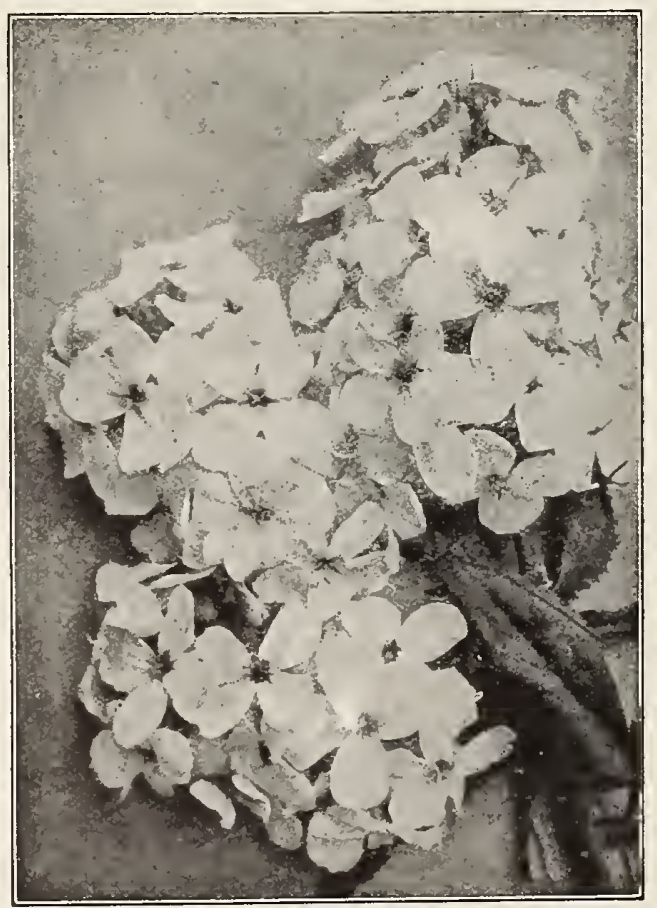

Hesperis matronalis

Perdoz.

GENTIANA Adrewsii (Blue Gentian). Pretty native species with blue flowers. H $1 \frac{1}{2}$, F 9 .

$\$ 200$

G'YPSOPHILA paniculata (Baby's Breath). When in bloom in August and September it forms a symmetrical mass, 2 to 3 feet in height and as much through, of minute white flowers having a beautiful gauze-like appcarance.

GLOBULARIA Tricosantha (Globe Daisy). Light blue flower. $\mathrm{H} \frac{1}{2}$ to $\frac{3}{4}, \mathrm{~F} 5$
HELIANTHUS. The hardy Sunfowers arc among the Per doz. 100 most desirable of hardy plants. They are freeflowering, have a long season of bloom, are very decorative in the garden, and are fine for cutting. All have bright yellow flowers.

Tuberosa (Jerusalem Artichoke). Very decorative: grows 12 fcet high; also a desirable vegetable... \$1 v0 $\$ 600$

Løtiflorus. The best, free-flowering, single yellow Howers; fine for eutting. H 4 to $5, \mathrm{~F} 7$ to $4 . . . . .$.
Maximiliana. Tall and very late; one of the nost statcly and elegant hardy plants in cultivation; lest Sunflower to bloom in the fall. $\mathrm{H} 7$ to 9 , F 10 to 11

125700

$150 \quad 1000$ site shape and bright orange-yellow, freely yroduced during August and September. Girand for cutting. H 5 ...

Orgyalis. A verv striking, tall Sunfower. I 5 to $6, \mathrm{~F}$ is to 10 .

Trachelifolius

Giganteus. Pale yellow flowers, 3 inches across: very clegant. $\mathrm{H} 4$ to $5, \mathrm{~F} 8$ to $9 \ldots \ldots \ldots \ldots \ldots 1$

Buttaris

Wolley Dod. The best of the Scptember flowering varieties; deep yellow flowers; distiuct and fine..

HELIANTHEMUM mutabile (Sun Rose). Charming dwarf evergrecu plants with pink and white flowers. $\mathrm{H} \frac{1}{2}, \mathrm{~F} 5$ to $6 \ldots \ldots \ldots \ldots \ldots \ldots \ldots \ldots \ldots$

HELENIUM Hoopesii. Bright orange flowers. $\mathrm{H} 2$ to $3, \mathrm{~F} 7$ to $8 \ldots \ldots \ldots \ldots \ldots \ldots \ldots \ldots$

Autumnale superbum. An improved variety of

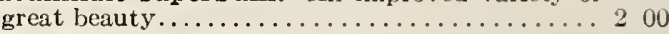

HELIOPSIS Pitcheriana. Similar to the hardy Sunflower, but blooming during a nuch longer season. H 3 to $6, \mathrm{~F} 8$ to $10 \ldots \ldots \ldots$. . $\ldots$ yellow flowers the best of the Heliopsis. H $3, F 7$ to $9 \ldots \ldots$. 150

HELLEBORUS niger (Christmas Rose) each, 35 ets. 350 HEMEROCALLIS Flava (Lemon Day' Lily). H 2 to $3, F$ to 7

Florham. Splendid new large-flower ing sort; bright yellow flowers.

Fulva (Orange Day Lily). H 2 to 3 , I 6 to 7 ....

Fulva flore pleno. Double.

Graminea. Bright yellow; one of the best.

Dumortieri. H $1 \frac{1}{2}, \mathrm{~F} 6$ to 7

Aurantiaca. Large orange-yellow fiow.

Aurantiaca major. New and very beautiful. Needs protection in wintcr. $\ldots \ldots \ldots \ldots 2,50$

Thunbergi. Bright yellow. H HERACLEUM giganteum (Giant Parsnip). A remarkable foliage plant.........25 cts. each..

HzSPIRIS matronalis, Purple (Swect Rocket). H 2 to $3, \mathrm{~F} 6$ to 9 250

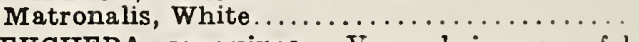

HEUCHERA sanguinea. Very ehoice, graceful
dwarf plant with lovely crinson flowers; fine for dwarf plant with lovely crimison flowers; fine for cutting. $\mathrm{H} \frac{3}{4}$ to $1 \frac{1}{2}, \mathrm{~F} 7$ to $9 \ldots \ldots \ldots \ldots \ldots 150$

Rain of Fire. A new and greatly improved variety. 200

HIERACIUM Aurantiacum. A low-growing, rapidspreading plant adapted for dry sandy spots or covering steep banks; orange-red flowers.... . . 150

HIBISCUS Moscheutos. Bright pink.......... 150

Moscheutos, "Crimson Eye." White. H 3 to 6 ,

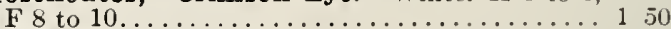

HOLL YHOCKS, Best Double............ 150

Best Single..................... 125

HONESTY. See Lunaria.

BYACINTHUS candicans. Showy white flowers, blooming in summer; easiest eulture...........

IBERIS (Candytuft) corifolia. Large snow-white flowers. $\mathrm{H}_{3}^{3}, \mathrm{~F} 5 \ldots \ldots \ldots \ldots \ldots \ldots \ldots \ldots$. . . . . . . . the ground with a mat of purc white flowcrs. H the ground with a mat of purc white flow. $1, \mathrm{~F} 4$ to 5 . Sempervirens nana. Improved dwarf variety..... 1 1

Sempervirens, "Queen of Italy." A new dwarf varicty with violet flowers; very pretty....... 125

$\$ 00$

$\checkmark 00$

IRIS Kæmpferi (Japancse Iris). See page 25

Pseudo-acorus variegata. Foliage beautifully variegated; flowers rich yellow; suitable for marshes and water-courses. H 3, F 5 to $6 \ldots \ldots 100$ 
HARDY HERBACEOUS PERENNIAL PLANTS, continued Iris Germanica (German Iris), 25 choice named Perdoz. 100 varieties. $\mathrm{H} 2$ to $3, \mathrm{~F} 6 \ldots \ldots \ldots \ldots \ldots \ldots \$ 125 \$ 800$ Germanica, Mixed Varieties.

sibirica sanguinea. Bright blue flowers. H 3 to $4, F 6$.

Sibirica alba. White.

Elorentina (Orris Root). Very large white fragrant flowers. H 2 , F 5 to $6 \ldots \ldots \ldots, 125$

Tectorum.................... 75

nNULA Helenium. Free-flowering border plants with yellow flowers. H $2, \mathrm{~F} 6$ to 8.150

INCARVILLEA Delavayi (Hardy Gloxiana) Large gloxinia-like rose-colored flowers that last a long time in perfection; should be protectcd by a covering of leaves in the winter.

$150 \quad 1000$

LATHYRUS latifolius splendens. Bright pink..............25 cts. each.. 250

Latifolius albus (White Everlasting Pea). These Everlasting Pcas are but little known in this country, but are great favorites in England. They are extrcmely showy and fine..........25 cts, each. 250

LAVENDER. The well-known garden herb... 100

LIATRIS pycnostachya. Striking hardy summer-blooming plant, with great rocket-like spikes of purple flowers. $\mathrm{H} 3$ to $5, \mathrm{~F} 6$ to $9 \ldots \ldots \ldots \ldots \ldots \ldots \ldots \ldots 150$

LINUM perenne (Flax). H $1 \frac{1}{2}, \mathrm{~F} 6$ to $8 \ldots \ldots 125$

Perenne album.

Perenne roseum

LOBELIA cardinalis. Native plant, with intensely brilliant cardinal flowers. $\mathrm{H} 2$ to

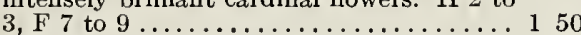

LUNARIA biennis (Honesty) ........... 125

LUPINUS polyphyllus. An extremely showy plant with large spikes of blue flowers; very effective but does better north of here, as it is partial to a eool climate. $\mathrm{H} 3, \mathrm{~F} 5$ to 6.150

I YCHNIS viscaria splendens Chalcedonica. Dense heads of brilliant scarlet flowers; one of the best border plants. $\mathrm{H} 1 \frac{1}{2}$ to $3, \mathrm{~F} 5$ to 8

Chalcedonica flore pleno. A fine double variety; fine for cutting............ 150

L YTHRUM superbum roseum. Very showy; spl endid for banks of streams and ponds. $\mathrm{H} 3$ to $5, \mathrm{~F} 7$ to $8 \ldots \ldots \ldots \ldots \ldots \ldots \ldots \ldots \ldots \ldots$

LYSIMACHIA nummularia aurea (Golden Perdoz. 100 Moneywort). Fine for carpeting..........\$1 $25 \quad \$ 500$ Clothroides (Loosestrife) Semi-aquatic, with white flowers. H 2 to $3, \mathrm{~F} 7$ to $9 \ldots \ldots \ldots \ldots \ldots 150$

Punctata. Showy yellow flowers. H $1 \frac{1}{2}$ to $2, \mathrm{~F} 6$.. 125

MERTENSIA Virginica. A lovely blue flower, blooming in early spring. $\mathrm{H} 2, \mathrm{~F} 4 \ldots \ldots \ldots \ldots$.

*MONARDA didyma (Bergamot). Very showy crimson flowers. H 2, F 7 to $9 \ldots \ldots \ldots \ldots \ldots \ldots \ldots 125$

*Didyma rosea

*Fistulosa (irild Bergamot). Mixed colors. H 2 to $4, \mathrm{~F} 6$ to 8 .

100

800

MONTBRETIA. Hardy bulbous plants, with spikes of flowers like a miniature Gladiolus; they may be treated the same as a Gladiolus and taken up every fall or allowed to remain in the ground and protected with a covering of leaves. They are very attractive and desirable for cut-fl, wers.

Aurea. Fine golden yellow.

Drap d'Or. Orange-red ccntcr...

Eclatante. Free-flowering red.

Eldorado. Reddish yellow.

Brilliant. Scarlet with decp purple spot in center.

Gerbe d'Or. Golden yellow.

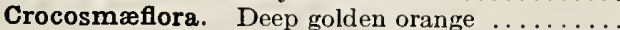

Rayon d'Or. Fine yellow and brown.

MALVA moschata rosea. This lovely Mallow blooms profusely in June and July, and grows 18 to 24 inches high. The flowers are rose$\begin{array}{lll}\text { colored; } 2 \text { inches across.................... } 1 & 50 \\ \text { oschata alba. Same as above with white flowers } & 1 & 50\end{array}$

Moschata alba. Same as above with white flowers
YoSOTIS palustris semperflorens (Water Forget-Me-Not). Splendid for naturalizing on edge of ponds and streams; also for beds and borders. 125

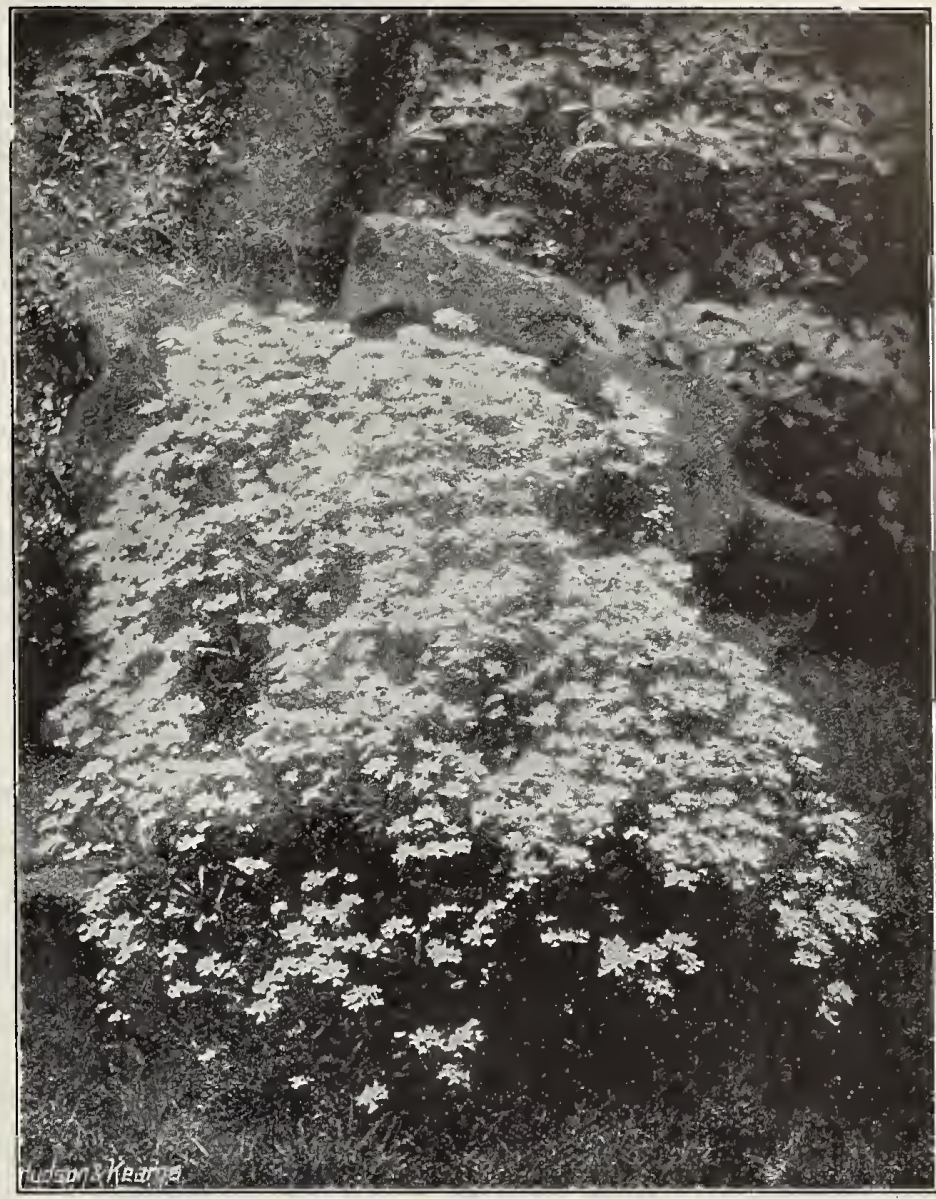

A Colony of Candytuft (Iberis) See page 46

OFNOTHERA (Evening Primrose). The Evening Perdoz. 100 Primrose is desirable and striking, and very effective in the garden on moonlight nights.

Splendens. A splendid dwarf variety, blooming in the daytime.

$\$ 1 \quad 25 \quad \$ 800$

Missouriensis.

Lamarckiana. Large sulphur-yellow flowers lovely beyond description. $\mathrm{H} 4$ to $5, \mathrm{~F} 7$ to $8 \ldots 150$

ONOPORDON Acanthium (Scotch Thistle). Noble plant, with striking foliage and showy purple flowers............................. 200

PANSIES, Best Strain. Plants for spring bedding. did. $\mathrm{H} 3, \mathrm{~F} 6 \ldots \ldots \ldots \ldots \ldots \ldots \ldots \ldots \ldots \ldots \ldots$

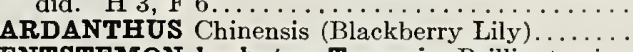

PENTSTEMON barbatus Torreyi. Brilliant crimson and orange flowers in July; one of the best

Digitalis. Showy spikes of pure white flowers.... 125

PEONIES, Good Varieties. Mixed.......... 200

Named Varieties . . . . .25 cts. to $\$ 1$ each; $\$ 2.50$ to 1000 $\begin{array}{lll}75 & 5 & 00\end{array}$

$40 \quad 300$

$\begin{array}{lll}75 & 5 & 00\end{array}$

$\begin{array}{lll}60 & 4 & 00\end{array}$

$\begin{array}{lll}4 & 00 \\ 7 & 00\end{array}$

500

225

$\begin{array}{lll}30 & 2 & 25 \\ 30 & 2 & 25\end{array}$

$50 \quad 700$

700

600
PHLOX subulata (Moss Pink). Rose-pink. Finc for covering banks; thrives in hot, dry situations, and blooms profusely...................... 100

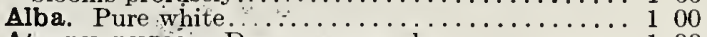

Atropurpurea: Deep rosy purple............... 100

Little Dot. White with blue center; small flowers of dainty habit. ....................... 100 G. F. Wilson. New; lovely light blue; distinct and fine. 10 cts, each $\ldots, 100$

Bridesmaid. Purplish, tinted white.......... 100

Model. Best pink variety................ 150

PHYSOSTEGIA Virginica. Erect spikes of pretty

pink flowers. $\mathrm{H} 11 \frac{1}{2}$ to $21 / 2 \ldots \ldots \ldots \ldots \ldots \ldots \ldots$

Virginica alba. A beautiful white variety. H 2 to

$3, \mathrm{~F} 7$ to $8 \ldots \ldots \ldots \ldots \ldots \ldots \ldots \ldots \ldots \ldots$

600

600

600

600

500

600

800 
PINK. See Dianthus.

PLANTAIN LILY. Sce Funkia.

PLUME POPPY. Sce Bocconia.

PLUMBAGO Larpentæ. A dwarf plant covering the ground completely with its foliage. In September it is a mass of beautiful decp bluc flowers, which gradually change to violet.

POLYGONUM cuspidatum (Giant Knotwced). Grow's to 12 fect high; makes a splendid group for tropical effect

Amplexicaule (Mountain Fleeec)..

* PRIM ULA vulgaris (English Hardy Primrose). H $\frac{i}{2}$ to $3, \mathrm{~F} 4$ to 5 .

* Veris (Polyanthus). H to $\frac{3}{4}$, F 5 to 6 .

Japonica. Bcautiful and desirable variety Auricula.

P YRETHRUM, Double Varieties

Single Varieties. The Single Pyrethrums are among the loveliest hardy flowers grown. They are splendid for beds and borders, and nothing can be finer for cutting. Their single, daisy-like flowers, of all colors, are produced in the greatest

profusion early in the spring and again in the fall.
RHEUM offleinale (Chinese Rhubarb). The immense leaves of this noble foliage plant produce a bold and striking effect. Robinson says this is the most effective foliage plant introduced for many years.

Collinianum. Like the above, but foliage more deeply cut; splendid. $\ldots \ldots$. . . 40 ets. each...
modi. Grows 5 feet high; wrinkled-leaved, with red veins; very effective........40 cts. each. . 400

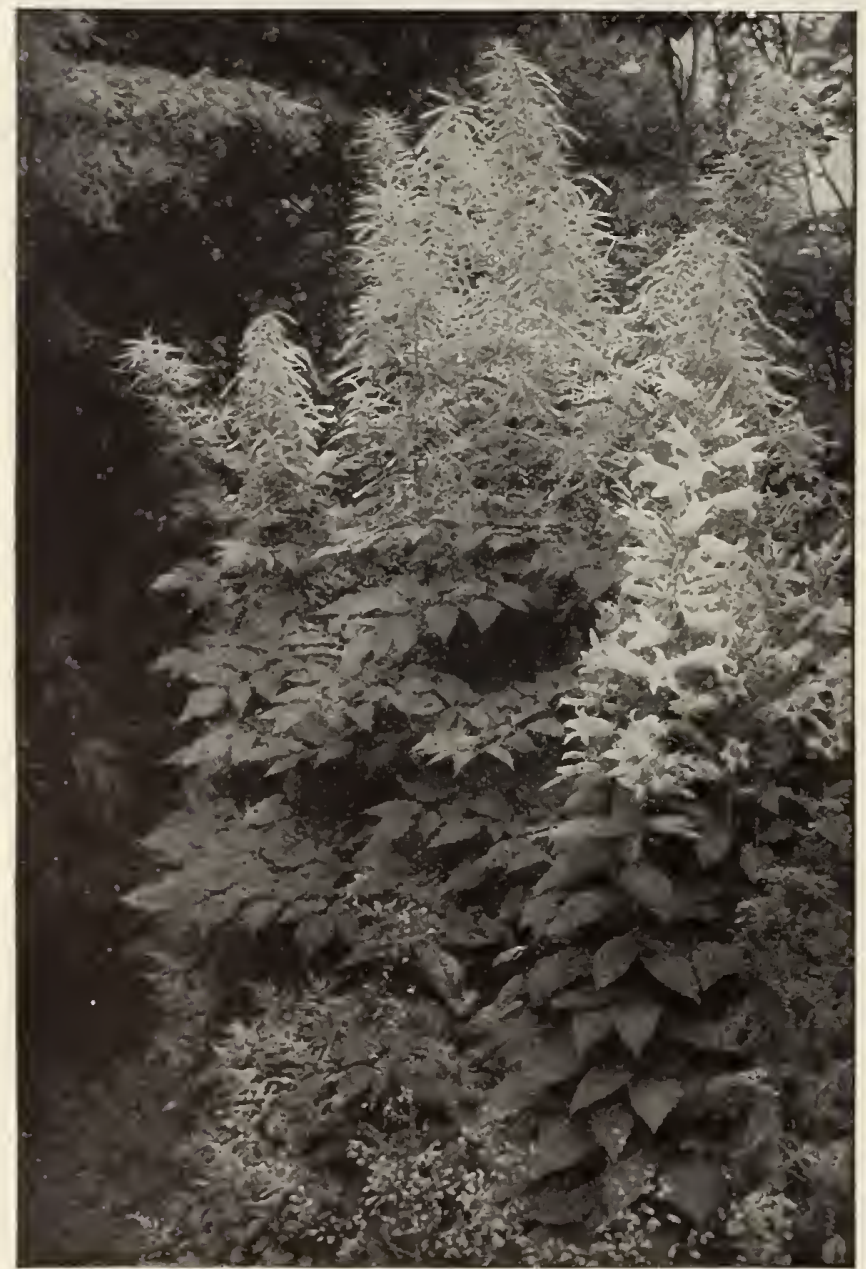

Spiræa Aruncus
Rneum Tanghuticum. Has finc foliage and is of Per doz. 100 rapid growth................ $40 \mathrm{ets}$. cach. .\$1 00

Giganteum. A tall, vigorous variety of striking

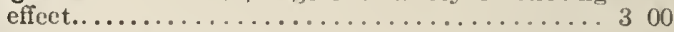

RANUNCULUS acris fl. pl. (Bachelor's Buttons). A showy border plant with double yellow flowers in early summer.

ROSEMARY. An old-fashioned plant with seented

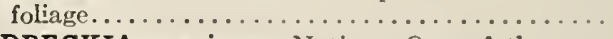
150

RUDBECKIA speciosa. Native. One of the very best border plants in cultivation. A group of "Golden Glow" surrounded by this variety makes a splendid effect. II 2 to $3, \mathrm{~F} 7$ to $9 \ldots \ldots \ldots \ldots$. "Golden Glow." Double Rudbeckia. Grows 10 to 12 fect high, and is undoubtedly one of the most effeetive plants in cultivation. It is becoming very popular. $\mathrm{F} 7$ to 9

Nitida

Hirta. Large crimson-maroon flowers; very distinct.

Sub-tomentosa. Densely branched plant, 21 feet high, completely covered throughout the summer with a mass of brilliant lemon-colored flowers, with purple centers.

RUTA graveolens (Rue). This is a well-known herb.

SAGE. The well-known herb.

SAPONARIA ocymoides splendens. A charming little creeping plant covered with bright lovely rosy crimson flowers during the month of June. 150

Offlcinalis $\mathrm{fl}$. pl. Beautiful plant growing about 2 feet high and blooming in August; large double flowers of a lovely sof trose-pink...............

SAXIFRAGA cordifolia. Large, shiny foliage and large panicles of bright pink flowers. $\mathrm{H} 1, \mathrm{~F} 4$ to 5.200

SCABIOSA Japonica. Lavender-blue flowers; very free-flowering from June to September; fine for cut-flowers; lovely...

Caucasica. Large head of pale blue flowers; one of the best hardy plants in eultivation; grows and flowers freely in any garden soil.

Caucasica alba. A white-flowered variety of the abor............................. 150

SEDUM stoloniferum................. 150

Spectabile. A fine fall-flowering plant with great heads of purple flowers. H $1 \frac{1}{2}, \mathrm{~F} 9$ to $10 \ldots \ldots \ldots 150$

Acre. Fine for covering graves and for carpeting.. 100

SCUTELLARIA macrantha. A handsome hardy plant growing about 9 inches high, and produeing an abundance of rich velvety dark blue flowers. . 100

SEA HOLLY. See Eryngium.

SILENE alpestris (Alpine Catchfly). Shects of eharming glistening white flowers, from May to July, makes a carpet only 3 inehes high........... 150

SILPHIUM perfoliatum. Yellow flowers. H 4 to 8 , F $7 \ldots \ldots \ldots \ldots \ldots \ldots \ldots \ldots \ldots \ldots \ldots \ldots \ldots \ldots$. tiful erimson flowers above splendid palmate foliage. H $2, \mathrm{~F} 7$ to $8 \ldots \ldots \ldots \ldots \ldots \ldots \ldots \ldots$

Palmata elegans. A lovely new variety with light

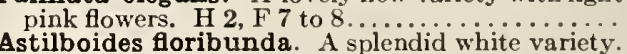
Astiboides fioribunda. A splendid white variety.

*Aruncus. A grand native sort, with great heads of white flowers. H 3 to $5, F 6$ to $7 \ldots \ldots \ldots \ldots$

Filapendula fl. pl. A beautiful dwarf variety, with elegant fern-like foliage. $\mathrm{H} \frac{1}{2}, \mathrm{~F}$ G to $7 \ldots \ldots \ldots$.......
obata. One of the handsomest of the Spireas, with

Lobata. One of the handsomest of the Spireas, with
deep rosy carmine flowers. H $1 \frac{1}{3}$ to $3, \mathrm{~F} 6 \ldots \ldots \ldots 150$

STACHYS lanata. White woolly leaves and purple flowers; useful for edging. H $1, F 7$. ..... 100

STATICE latifolia.................... 150

Armeria (Sea Pink).................... 125

SWEET WILLIAM. See Dianthus barbatus.

TEUCRIUM Chamædrys. Evergreen shining leaves; purple flowers; will grow on barren soils........ 125

THALICTRUM aquilegifolium. All Thalictrums have liandsome foliage, and this variety has quite showy flowers. H 3 to $4, \mathrm{~F} 6$ to $7 \ldots \ldots \ldots \ldots 150$ Adiantifolium. Beautiful foliage like maidenhair fern................. 125 Glaucum. Bronzy yellow flowers, bluish foliage.. I 50

\section{0}

1000 1200 1200 


\section{HARDY HERBACEOUS PERENNIAL PLANTS, continued}

THERMOPSIS Caroliniana. Showy plant, with Per doz. 100 attractive yellow flowers...............\$1 50

*TIARELLA cordifolia (Foam Flower). A most charming dwarf spring-flowering plant, with beautiful white flowers and lovely foliage....... 150

*TRILLIUM grandiflorum ................. 35

*Erectum album

TRITOMA uvaria grandiflora (Red-hot Poker). Needs protection; a striking fall-flowering plant.

$\mathrm{H} 3$ to $4, \mathrm{~F} 9$ to $11 \ldots \ldots \ldots \ldots \ldots \ldots \ldots$

Pfltzerii (Flame Flower, or Torch Lily). This new Tritoma is undoubtedly one of the most valuable introductions of recent years. Tritoma unaria, or "Red-hot Poker" plant, is highly prized on account of its picturesque appearance and its blooming so late in the fall after almost everything else is gone. This new variety is a great improvement in every respect. The flowers are much more refined and beautiful, and are produced in the greatest profusion from early summer until late fall, coming into bloom at least two months before the older variety. It is equally desirable for garden effect or for cut-flowers, and is decidedly unique.................each, 15 cts... 1501000

TRADESCANTIA Virginica (Spiderwort). Produces a succession of purple flowers all summer.. 125

T UNICA saxifraga. A pretty tufted plant with light pink flowers, produced all summer; useful either for the rockery or the border............... 150

ONIFOLIA latifolia. A very useful ornamental grass........................... 150

VERBASCUM nigrum. Yellow flowers in long spikes ; dwarfed habit.........20 cts. each.. 200

Olympicum. Bright yellow flowers; large woolly foliage; stately.............25 cts. each.. 250
Verbascum phœniceum. Seedlings; crimson-rose, Perdoz. 100 lilac and white; large and showy...30 cts. each. .\$3 00

Pannosum. Sulphur-yellow flowers; new specics, with white foliage............35 cts. each. . 300

VERBENA venosa. A hardy Verbena; very extensively used in England for bedding. It grows about 18 inches high, but pegged down will cover the ground with heads of lovely purple-violct flowers throughout the season. Not quite hardy, except on thoroughly well-drained soils.........

VERONICA longifolia. Spikes of deep bluish purple flowers; very handsome. H 2, F 8 to $9 \ldots \ldots \ldots .200$

Spicata. Violet-blue flowers in long spikes; dwarf habit. ............................ 150

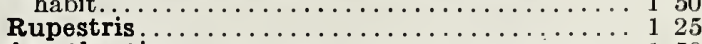

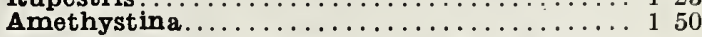

VINCA coorulea. The well-known hardy Myrtle; fine for carpeting under trecs where grass will not grow........................ 125800

VIOLA pedata (Bird's-foot Violet). A beautiful native sort. (Birds-foot Violet). A beautiful 100

Pedata bicolor. Deep purple flowers.....

Cornuta. Flowers almost as large as a Pansy. This is the most desirable of hardy plants. Blooms continuously all season; blue flowers.......... 150000

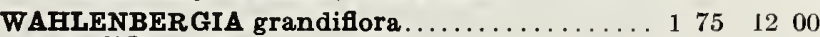

Grandiflora alba...................... $175 \quad 1200$

YUCCA fllamentosa (Spanish Bayonet). Fine, strong plants; a stately decorative plant, with immense spikes of large white flowers; fine for the garden or lawn....................... $250 \quad 1600$ The above Yucca is also known as the Mexican Soap Plant.

Angustifolia.

\section{ORNAMENTAL FLOWERING SHRUBS}

Our stock of shrubs is unsurpassed in quality, but our prices will be found much lower than those made by most nurserymen. As a rule, shrubs are much more effective when planted in masses, and our low prices permit them to be used freely in this way. For a guide in planting, we have indicated the size the shrubs will eventually be, as follows: " $\mathrm{H} 3-4$, S $3-4$ June" which means "Height 3 to 4 feet, spread 3 to 4 feet, flowers in June." The sizes given can only be approximate as the size shrubs attain varies considerably with soils and climate.

Shrubs marked * can be grown in partial shade, but they will also thrive in full exposure to the sun.

\section{SPECLAL OFFER OF SHRUBS}

We want to encourage the planting of shrubs. To be effective they should be planted in masses, but when dealers or nurserymen ask fifty cents each for easily grown shrubs there is not much encouragement to plant them freely. We have made arrangements by which we can supply our customers with well-grown shrubs in the best varieties at the extremely low prices quoted below, but in every instance the selection of varieties must be left to us. But in ordering, if it is stated that certain shrubs are not wanted they will not be sent. We guarantee these shrubs to be satisfactc ${ }^{-r}$ in both quality and variety. We can not give in advance of filling the order a list of varieties contained in these collections.

SPECIAL OFFER A- 50 shrubs in fine assortment of 15 varieties.

ALMOND. Dwarf Double-flowering Pink. Each Per doz. 100 H 3-5, S 4, May ................. \$0 $35 \quad \$ 3 \quad 50$

Dwarf, Double-tlowering white........... $35 \quad \begin{array}{ll}3 & 50\end{array}$

ALTHEA Buist's Variegated. Exceptionally fine for hedging purposes, as well as for producing marked contrasts in groups of mixed shrubbery. H 8-10, S 4-6, August and September.............25

Double. Fine distinct named varieties..... 20

Single Dwarf White. Pure snowwhite; fine

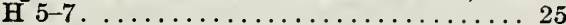

Seedlings. Mixed colors, single and semi-

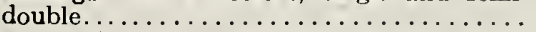

Jeanne d'Arc. A new perfectly double, pure white flower, and a great acquisition. It supersedes all the so-called double white varieties, being entirely immaculate...........

single-flowered Varieties. In white, blue and pink; very lovely and desirable........ 20

AMELANCHIER Canadensis (Juneberry).

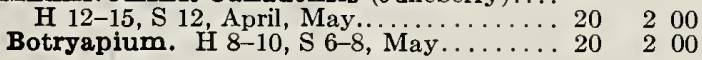

AMORPEA fruticosa. (False Indigo). H 68, S 8, June...................... 20

Conescons H $2-3, \mathrm{~S} 2$, June........... 200
ARALIA Japonica. A distinct and most Each Per doz 100 beautiful tall shrub with palm-like leaves and large heads of white flowers in August. H 8-12, S 5 ...............\$0 $40 \quad \$ 400$

Pentaphylla. A shrub little known but very desirable. The effect of the luxuriant glossy foliage on the arching branches is very bcautiful. H $5-7$, S $5-6 \ldots \ldots \ldots \ldots \ldots \ldots \ldots 25$

AZALEAS. Should always be planted in the spring or early in September. $\mathrm{H} \mathrm{4-6,} \mathrm{S} \mathrm{4}$, April-May

*Arborescens. A strong-growing native species, with very fragrant rose-colored flowers. 12 to 18 inches; fine plants...........75

*Calendulacea. A splendid native Azalea, with orange-colored flowers. Strong and vigorous in growth............. $100 \quad 1000$

*Ghent. 15 inches................. 1251200

Mollis. 12 to 18 inches; with bloom buds; splendid plants.............. $100 \quad 1100$

*Nudiflora. A native species, with fragrant pink flowers................. $50 \quad 500$

*Vasezi. Fine plants................. 1501600

ANDROMEDA Mariana. Small shrub, with lovely pinkish white flowers. H 2-4, S 3. $\quad 30 \quad 300$ 


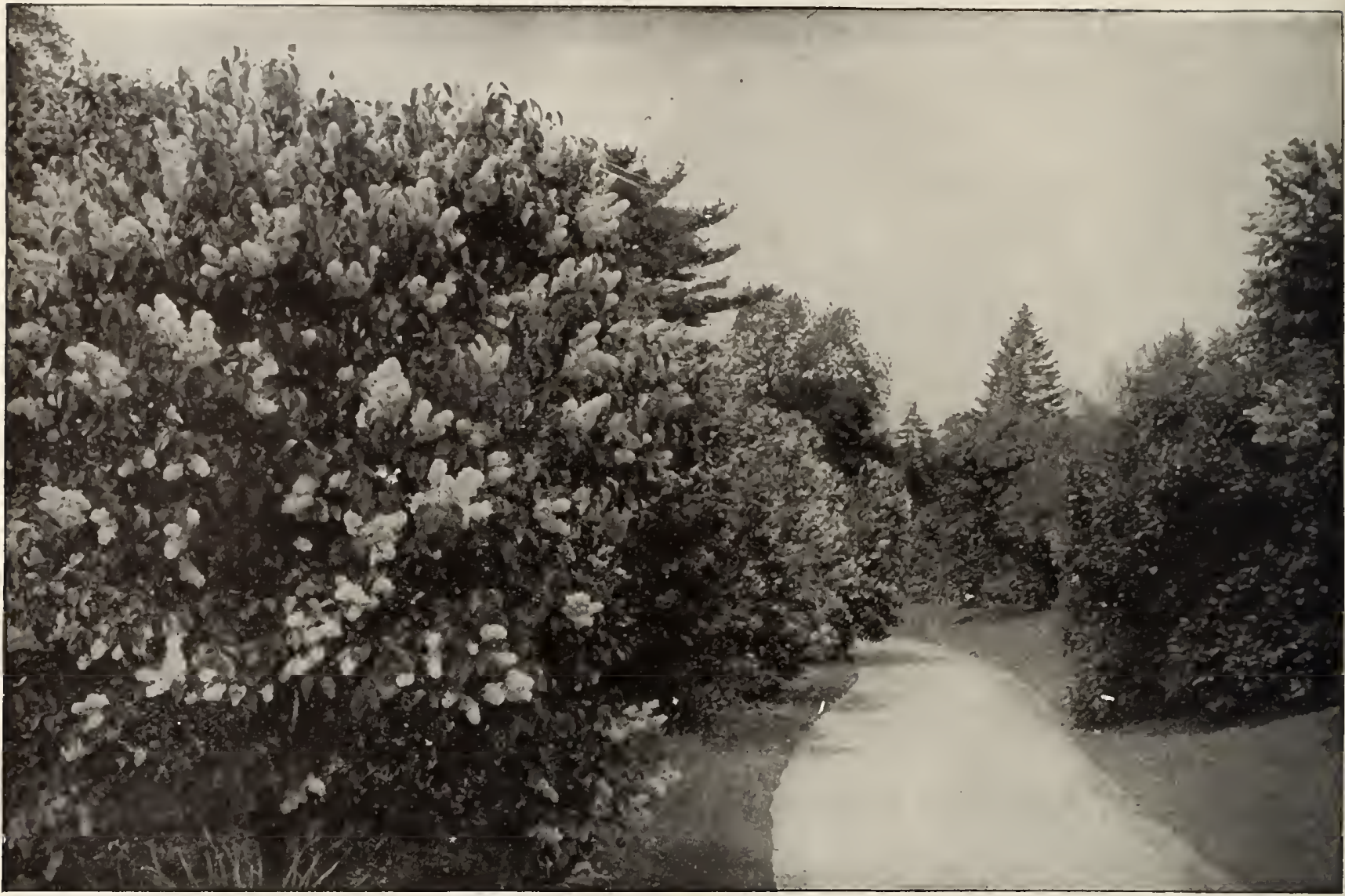

An attractive walk bordered with White Lilacs

\section{ORNAMENTAL FLOWERING SHRUBS, continued}

BFRBERIS Sieboldi. H 5-6, S 4-5.... Each Per doz. 100

*Japonica. Similar to Thunbergii, but more vigorous in habit......................

*Thunbergii (Japanese Barberry). One of the most desirable shrubs in eultivation on account of its habit, foliage and fruit; fine

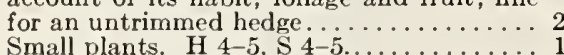

*Vulgaris (European Barberry). A magnificent shrub when it attains its full development; long raeemes of yellow flowers in May followed by orange-scarlet berries which last all winter. H $6-8, \mathrm{~S} 6-8 \ldots \ldots \ldots \ldots \ldots 20$

* Vulgaris purpurea (Purple Barberry). H 5-

6 , S $5-6 \ldots \ldots \ldots \ldots \ldots \ldots \ldots \ldots \ldots \ldots \ldots \ldots \ldots$.

BODDLEIA. Little known but very attractive
summer-flowering shrubs. In this climate the tops usually kill to the ground in the winter, but the roots are perfeetly hardy. A vigorous new growth, which flowers frcely, is produced every season. H 4-5, S 4-5. Lindleyana. Violet-purple flowers in arching racemes 6 to 8 inches long.......... 35

Variabilis. Lilac flowers produced in dense tcrminal panicles 4 to 6 inehes long.......

CAL Y CANTHUS floridus (Swcet-scented AGANA arborescens (Siberian Pca). Pale

CARAGANA arborescens (Siberian Pca). Pale
yellow pea-shaped flowers. H 8-10, s 8 ,

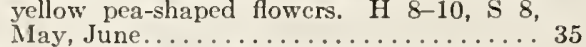

CAR YOPTERIS Mastacanthus (Blue Spirea). Not very hardy. H $2-3, \mathrm{~S} 2-3 \ldots \ldots \ldots .30$

CASSIA Marylandica (Wild Scnna). Peashaped yellow flowers. H 3-4, S $4-5 \ldots \ldots .15$

OEANOTHOS Americanus (Jerscy Tea) Sweet-seented white flowers. H 2-3, S 3. July-September..................20
$175 \quad 1300$

$200 \quad 1300$
C E P H A L A N T H O S Occidentalis (Button Each Per doz. 100 Bush). Curious round balls of white flowers in July. H $6-8$, S $6 \ldots \ldots \ldots \ldots \ldots \ldots$ \$0 $20 \$ 200$

CERCIS Japonica (Japanese Red Bud or Judas). Very showy pink flowers before the leaves appear in April. H $4-5, \mathrm{~S} 4-5 \ldots \ldots \ldots \ldots$

CHIONANTHOS Virginica (White Fringe). H 10-12, s 6-8, May, June..............

CLETHRA alnifolia (Sweet Pepper). A splendid summer-blooming shrub, with delicious white sweet-seented flowers. H $3-5, \mathrm{~S} 4$, July-September...................20

COLOTEA arborescens (Bladder Scnna). Rapid growth. H 7-8, S 6-8..........

CORNUS (Dwarf or Shrubby Dogwoods). Very valuable shrubs on account of their casy growth, luxuriant foliagc, bright-colored bark and showy fruits. Fine for massed and water-side planting.

*Alba, or Sibirica (Red-twigged Dogwood). Fruit bluish white. H 6-8, s $6 \ldots \ldots \ldots \ldots 20$

*Alternifolia (Blue Dogwood. I 6-8, S 6... 25 Mascula (Cornelian Cherry). Very showy bright scarlet fruit. H $8-10$, S $6-8 \ldots \ldots .30$

* Sanguinea (European Red Osier). Decp red bark; black berries. H $6-8, \mathrm{~S} 6 \ldots \ldots \ldots .20$

*Sericea. Red bark, bluish fruit. H $8-10$, S 6-8

*Stolonifera (Red Osier Cornel). Dwarfspreading shrub, white berries. H 4-5, S 5. 20

* Stolonifera pendula. Pendulous variety of above; distinct and fine.............. 20

Spæthi aurea. Yellow variegated foliage.

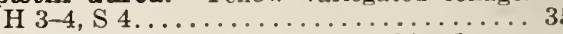

Kousa (Japanese Dogwood), A white-flowering variety of great beauty and rarity; grows into a small tree............... 75
$200 \quad 1300$

250

300

$200 \quad 1500$

$175 \quad 1300$

$\begin{array}{llll}175 & 1300\end{array}$

$200 \quad 1500$

350

800 
ORNAMENTAL FLOWERING SHRUBS, continued

CORCHORUS Japonica (Kerria Japon-Each Per doz. 100 $i c a$ ). Single yellow; blooms freely in summer time. H $4-6, \mathbf{S} 4 \ldots \ldots \ldots \ldots \ldots \ldots \ldots 020 \quad \$ 200$

Japonica fl. pl. A superb summer-blooming shrub, with showy double yellow flowers. H 4-6, S $3 \ldots \ldots \ldots \ldots \ldots \ldots \ldots \ldots \ldots$. . . . . . $20 \quad 200$ beautiful, graceful foliage. A dainty, charming shrub that should be freely planted. H $3-4$, S $3 \ldots \ldots \ldots \ldots \ldots \ldots \ldots \ldots \ldots 20$

CORYLUS Americana (American Hazelnut). H $8-10$, S $6 \ldots \ldots \ldots \ldots \ldots \ldots \ldots \ldots . \ldots \ldots$

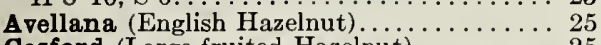

Cosford (Large-fruited Hazelnut)......... 25

Purpureus (Purple Hazel). Rich purple

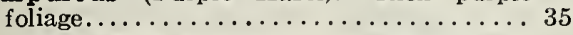

COTONEASTER Simonsi. Dwarf shrub with attractive red fruit; not very hardy....... 30

CRAT \&GUS, or Hawthorn. Are very attractive spring-flowering shrubs. Very sweetscented and showy. They are large shrubs and eventually grow into small trees, but the growth is slow. They are covered with attractive red berries in the summer and fall. H 10-20, S 10-20.

Coccinea (American Hawthorn) .......... 40

Oxyacantha (English Hawthorn) ............ 20

Double-flowered Rose ................ 50

Double-flowered Scarlet. ............. 50

Double-flowered White ................ 50

Pyracantha Lalandi (Evergreen Thorn). One of the most beautiful Thorns. Covered with splendid scarlet fruit in fall and winter. Not hardy north of Pittsburg, except near

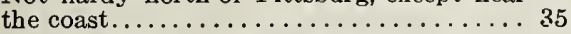

CYDONIA Japonica (Japan Quince). Brilliant red; very subject to San José scale. H 4-5,

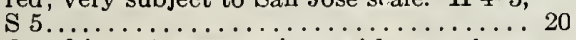

Columbia. A new variety with very large fruit...................... 75

CERASUS Virginiana. A large shrub with brilliant showy fruit; very attractive. $H$ $10-12, \mathrm{~s} 6-8 \ldots \ldots \ldots \ldots \ldots \ldots \ldots \ldots \ldots . . . \ldots 55$

250

250

250

350

300

$400 \$ 3000$
100

$150 \quad 1000$

500

500

500

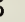

350

$200 \quad 1500$.

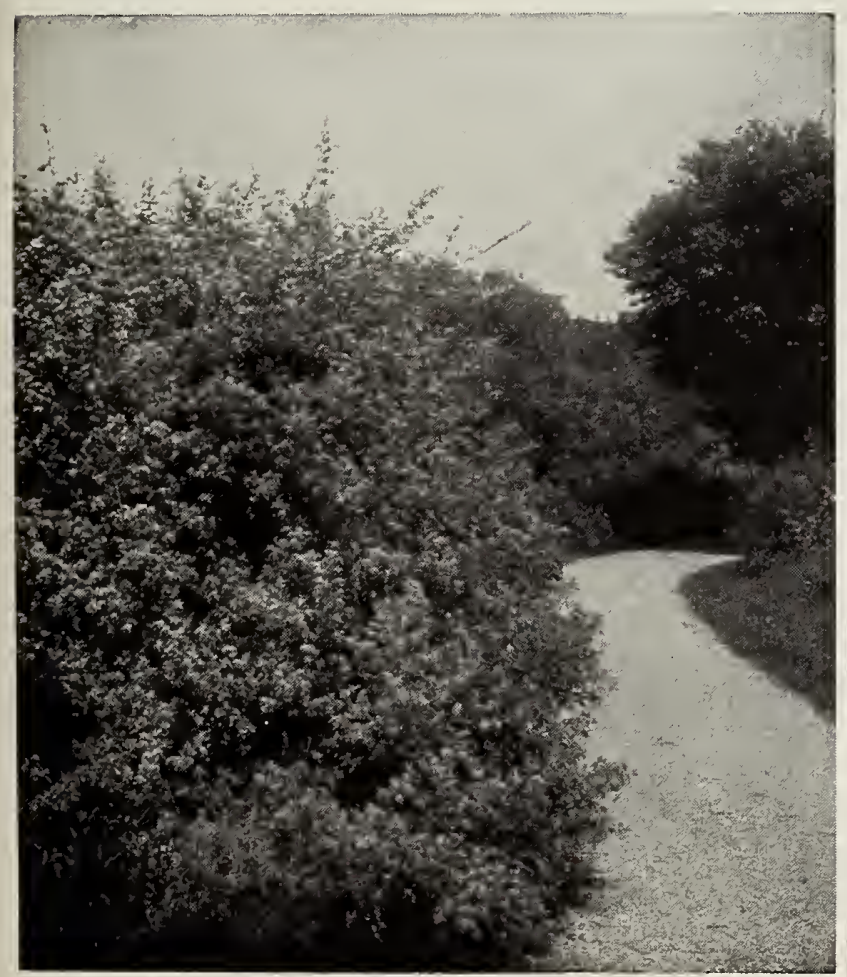

Lonicera bella (see page 52 )
CYTISUS Iaburnum (Laburnum or "Golden Each Per doz. 100 Chain") ....................... \$0 $50 \quad \$ 500$

DESMODIUM penduliflorum. An excecdingly graceful shrub-like plant, covered with purplish red flowers in summer-time when little else is in bloom; strikingly beautiful. H $3-4, \mathrm{~S} 4 \ldots \ldots \ldots \ldots \ldots \ldots \ldots \ldots 20$

DEUTZIA candidissima. Double white flowers. H 6-8, S 6, May, June............ 20200

Crenata fl. pl. Double pink flowers. H 6-8,

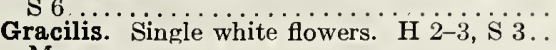

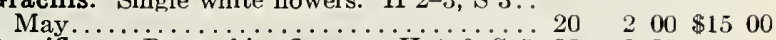

Parviflora. Pure white flowers. H 4-6, S 5. $30 \quad 300$

Lemoinei. A dwarf and exceedingly freeflowering shrubs with pure white single flow-

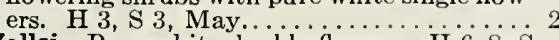

Wellsi. Pure white double flowcrs. H $6-8, \mathrm{~s}$

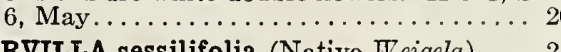

DIERVILLA sessilifolia (Native Weigcla).... 2
ELAMAGNUS Longipes. A new and handsome shrub with ediblc fruit. Truc varicty. H $6-8$, S 6 .

Umbellatus. $\mathrm{H} 10-12, \mathrm{~s} 8 \ldots \ldots \ldots \ldots \ldots \ldots$

Angustifolius. Silvery gray foliage, like the olive. H $10-12, \mathrm{~S} 8 \ldots \ldots \ldots \ldots \ldots \ldots \ldots$. . . . . . .

EUON YMUS atropurpureus (American Burning Bush). H 8-12, S $6 \ldots \ldots \ldots \ldots \ldots \ldots 3$

Europæus (European Burning Bush) . . . . 25

\section{EXOCHORDA}

Grandiflora (Pearl Bush). A rare Chinese shrub with pure white flowers. H 8-10, S 6. 25

FORS YTHIA Fortunei (Fortune's GoldenBcll). Magnificent vigorous-growing shrub,covered with yellow bell-like flowers before the foliage appears in the spring. Splendid for planting on steep banks, and especially above a retaining wall, as some of the branches grow upright while the remainder will hang down over the wall for several feet. H 6-8, S 5, April...................... 20

Suspensa (Drooping Golden Bell). Long,pendulous branches which hang down over a wall like a vine. ................. 20

Viridissima. This is the erect form of Forsythia. H $8-10$, S $6 \ldots \ldots \ldots \ldots \ldots \ldots \ldots 20$

GENISTA elatior (Hardy Broom). A beautiful dwarf yellow-flowered shrub. H 3-4, S 4, June......................... 25

Scoparia (Scotch Broom).................
ALESIA Tetraptera (Silver Bell). This is

HALESIA Tetraptera (Silver Bell). This is one of the most beautiful-flowering large flowers. H $15-20$, S $8 \ldots \ldots \ldots \ldots \ldots \ldots 20$

H A M A MELIS Virginica (Witch Hazel). Blooms in late fall and early winter. H 6-8, $\mathrm{S} 6 \ldots \ldots \ldots \ldots \ldots \ldots \ldots \ldots \ldots \ldots \ldots, 30$

Japonica. A rare Japanese variety.............. 75

HIPPOPHAE rhamnoides (Sea Buckthorn). H $8-10$, S $8 \ldots \ldots \ldots \ldots \ldots \ldots \ldots \ldots . \ldots \ldots$

HYDRANGEA arborescens. Native variety. 15

*Arborescens grandiflora. New variety with immense heads of white flowers. H 3, S 3.30

Paniculata. Distinct from $P$. grandiflora. A very striking and elegant shrub. H 5-6, S 5. 20

Paniculata grandiflora. The well-known hardy Hydrangea. H $4-5$, S $4 \ldots \ldots \ldots \ldots 20$

Quercifolia (Oak-leaved Hydrangea). Very handsome. H $3-4$, S $4 \ldots \ldots \ldots \ldots \ldots \ldots$.

*Radiata. Handsome native variety; fine for naturalizing. H $3-4$, S $4 \ldots \ldots \ldots \ldots \ldots \ldots 20$

HYPERICUM densiflorum. Yellow flowers. H $2-3$, S $3 \ldots \ldots \ldots \ldots \ldots \ldots \ldots \ldots \ldots \ldots$. . . . . . . .

Moserianum. Extremely beautiful and desirable large golden yellow flowers.......... $20 \quad 200$

Proliflcum. H 2-3, S 2-3............. 20 $200 \quad 1400$

IIEX verticillata (Deciduous Holly). Valuable for its brilliant scarlet berries in fall and winter. Will grow in swampy ground, and the berries are very fine for interior decorations. H $8-10, \mathrm{~S} 6 \ldots \ldots \ldots \ldots \ldots \ldots, 35$

$200 \quad 1300$ 
ORNAMENTAL FLOWERING, SHRUBS, continued

ITEA Virginica. Swottsected white flowers early summer. $H+5, \$ 4 \ldots \ldots \ldots \ldots . \$ 20$

LILAC, Common Purple. $2 \frac{1}{2}$ feet......... 20

18 inehes....................... 15

Uommon white. 2 to 2 feet............. 20

Persian. White and purplc; small flowers.... 25

$\begin{array}{rrrr}\$ 1 & 75 & & \\ 2 & 00 & \$ 15 & 00 \\ 1 & 50 & & \\ 2 & 00 & & \\ 2 & 50 & 16 & 00\end{array}$

NEIV VARIETIES OF LILAC3

Strong, 2-year budded plants (deseribed below). For prices of namea Lilacs, grown on their own roots, see page 18

Bertha Dammann. Immense trusses of pure white flowers; very profuse bloomer. $50 \mathrm{cts}$, each.

Emily Lemoine. Double; very large rosy lilac flowers; fine. 50 ets. each, $\$ 5$ per doz.

Lemoinei flore pleno. One of the oldest of the double Lilacs, and an excellent kind. Simply a double Vulgaris. Large and fine. 35 cts. each, $\$ 3.50$ per doz.

Hyacinthnoides. Hyacin th-like flowers. 35 ets. each, \$3.50 per doz.

Leon Simon. Double, compact panicles; flowers bluish crimson. 50 cts. each, $\$ 5$ ver doz.

La Tour d'Auvergne. Double purplish violet. 35 ets. each, $\$ 3.50$ per doz.

Souvenir de la Spath. The most distinet and beautiful variety in the collection. Trusses immense; very eompact; florets very large, deep purplish red. Growth vigorous. 35 ets. each, $\$ 3.50$ per doz.

Josikæa (Chionanthus-leaved Lilae). A very distinct and beautiful species from Hungary, with violet flowers blooming in early summer. H 8-10, S 8. 30 cts. each, \$3 per doz.

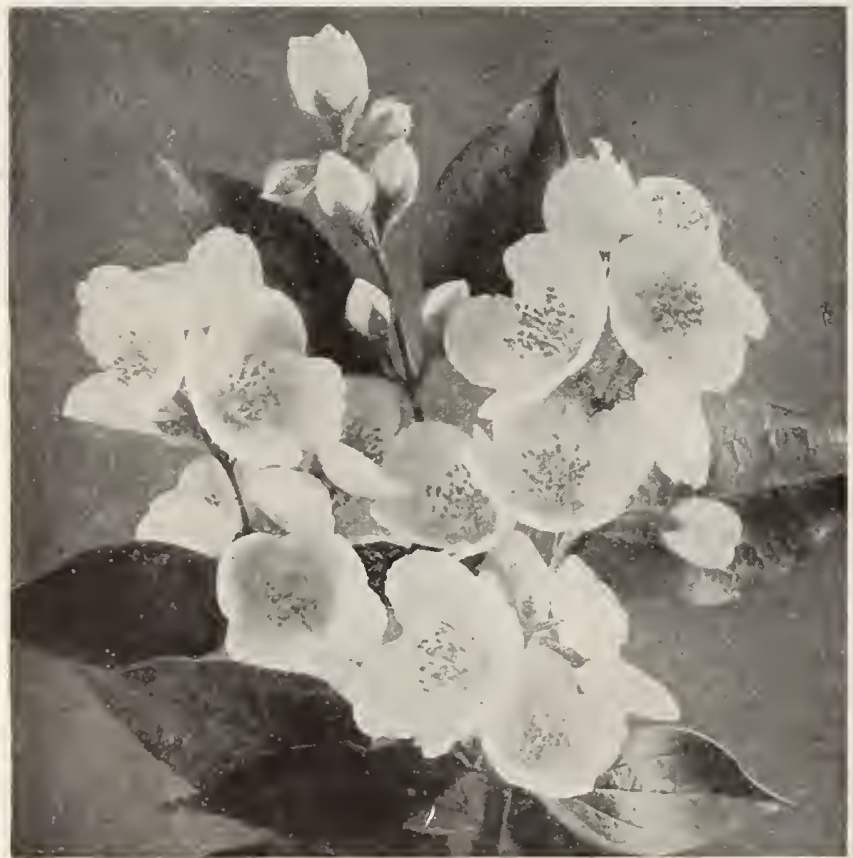

Philadelphus coronarius

LILAC, Japonica. A new and unique species Each Per doz. 100 from Japan, attaining the size of a small tree, with large panieles of white flowers; foliage very large, thiek and deep green eolor; blooms a month later than other Iilaes.

s0 $50 \$ 500$

villosa. Another new Japanese species, with foliage resembling the White Fringe (Chionanthus), and producing immense panicles of pinkish flowers late in the season; splendid. H 8-12, 58 .

Emodi. A wild species with large shining leaves; whitish flowers in June..........25 250

LONICERA (Upright Honeysuckle). These are very vigorous free-growing shrubs that are very showy and desirable both on account of
Lonicera, coutinued

their pink or white flowers whieh are frecly produed in the spring and their bright red or orange fruit with which they are covered in the summer. $H>-10$, s $6-\delta$.

Morrowi. Flowers pure white; fruit red...\$0 $25 \quad \$ 250$

Ruprechtiana..................20 20 00

Bella candida, rosea and albida. New and extremcly beautiful in flower and fruit.... 25

Tatarica. Pink flowers............... 20

Tatarica alba. White flowers............ 20

Xylosteum (Fly Honeysuekle)........... 20

Fragrantissima. A very early sweet-scented

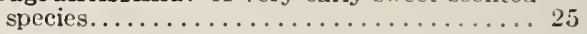

MYRICA cerifera (Wax Myrtle, Bayberry or Candleberry). H $4-6,85 \ldots \ldots \ldots \ldots .35$

$250 \$ 2000$

200

200

200

250

PAVIA macrostachya (Dwarf Horse-Chestnut). Beautiful spreading shrub with large heads of white flowers in June; fine for specimen on the lawn...................... 75

PHILADELPHUS (Syringa, or Mock Orange). Vigorous-growing with showy white and mostly sweet-scented flowers.

Aurea. Yellow leaved. H 4-5, S 4-5..... 30

Coronarius. Very sweet-seented white flowers. H $8-10$, S $8 \ldots \ldots \ldots \ldots \ldots \ldots \ldots .20$

Falconeri. Starry white flowers, borne in great profusion. H $6-8, \mathrm{~S} 6 \ldots \ldots \ldots \ldots \ldots \ldots 20$

Grandiflorus. Large flowers very showy. H

Lemoinei. A new dwarf variety of wonderful 20 beauty. H 4-5, S 5 .

Mont Blanc. One of the newer dwarf sorts; large white flowers borne in the greatest profusion. H $4-5$, S $5 \ldots \ldots \ldots \ldots \ldots \ldots \ldots \ldots$

Sutzmannii. Large showy white variety. H
$8-10$, S $8 \ldots \ldots \ldots \ldots \ldots \ldots \ldots \ldots \ldots$

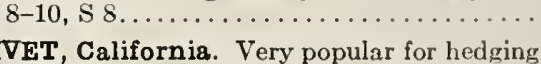
but sometimes killed to the ground during very cold weather.

1 year old

2 years old

3 years old

in elegant new Privet; fine for the shrubbery or for hedges; perfeetly hardy. H $10-12$, S 8 . .

*Ibota. Very graceful and handsome..... 20

*Amoor River. (True.) Very hardy and desir-

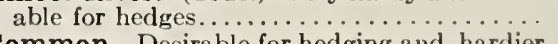

*Common. Desirable for hedging and hardier than California Privet.................

Ligustrum Media. A Privet of beautiful
habit; fruits immensely..............

POTENTILLA fruticosa ............. 25

PRUNUS Sinensis rubra. A dwarf Chinese Plum of great beauty. Double red flowers. $25 \quad 2 \quad 50$

Maritima (Beach Plum). Dwarf bush Plum, which makes an extremely ornamental shrub on account of its flowers as well as its fruit, which is produeed on bushes when only 2 feet high. The fruit is edible and makes an excellent preserve. H $5-8, \mathrm{~S} 6 \ldots \ldots \ldots \ldots 25$

Pissardi (Purple-leaved Plum). Desirable on account of its rich purple foliage. $\mathrm{H} 10-12$, S $8 \ldots \ldots \ldots \ldots \ldots \ldots \ldots \ldots \ldots \ldots \ldots \ldots \ldots \ldots \ldots, 30$

Triloba, A desirable flowering Plum with double pink flowers; very beautiful...... $30 \quad 300$

PHOTINIA Villosa. Very attractive red berrics. H $10-12, \mathrm{~S} 8 \ldots \ldots \ldots \ldots \ldots \ldots \ldots .40$ 1500

PYRUS arbutifolia (Choke Berry). A native shrub of great beauty and easy culture. Covered with white flowers early in spring, followed by bright red berries which last all winter. $H 4-5$, S $5 \ldots \ldots \ldots \ldots \ldots \ldots . . .20$

RHAMNUS cathartica (Buckthorn). Stronggrowing shrub with black berries. H 8-10,

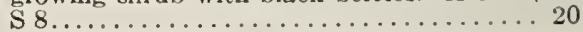

RHODOTYPUS kerrioides. $\quad 1,5 \leq 5 \ldots 20 \quad 200$ 


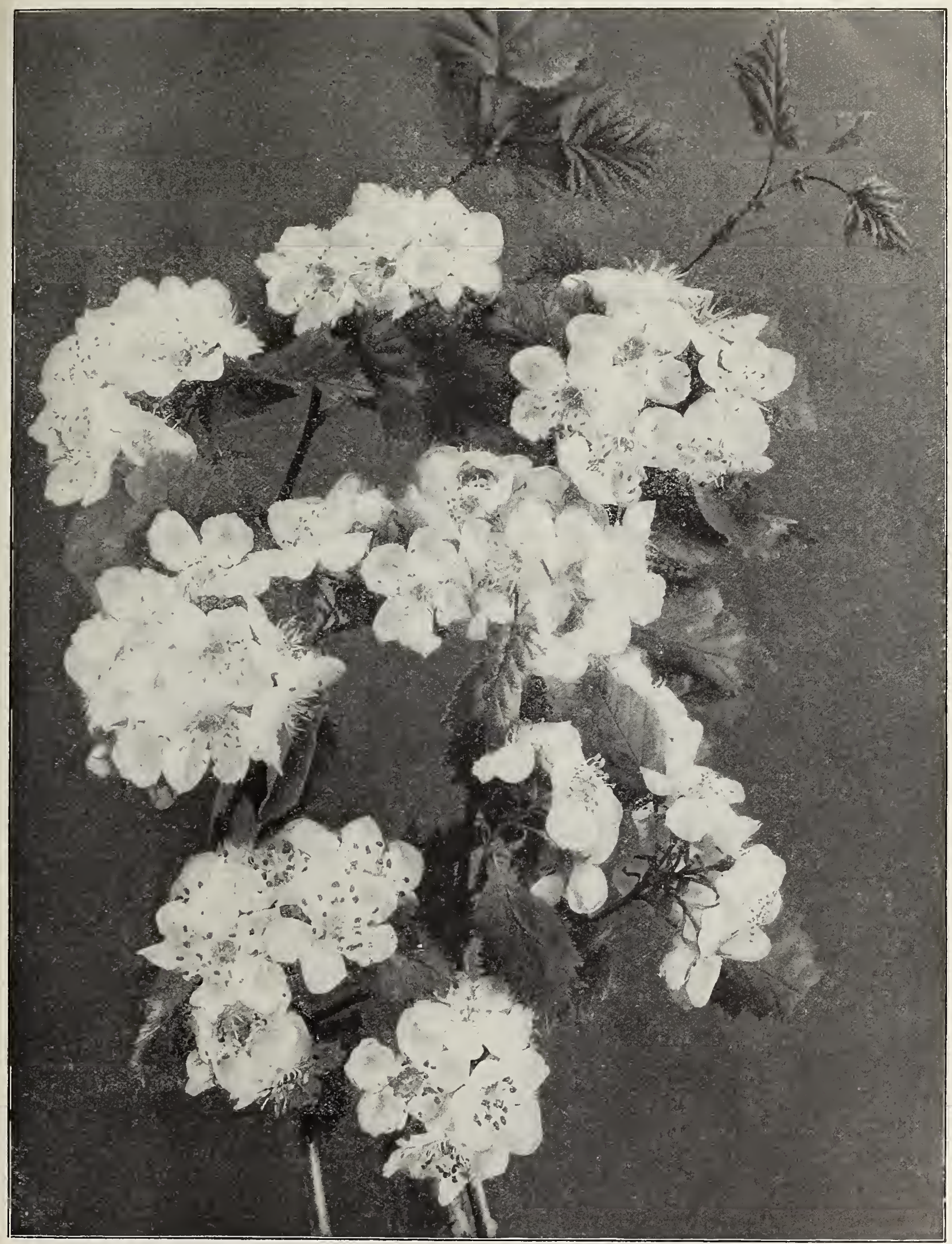

CRATAEGUS COCCINEA

One of our native shrubs which is beautiful in foliage, flower and fruit. It makes $a$ densa shrub, snd in tima $a$ small tree 


\section{ORNAMENTAL FLOWERING SHRUBS, continued}

RHUS copallina (Shining-leaved Sumac). Each Per doz. 100 H $4-6, \$ 5 \ldots \ldots \ldots \ldots \ldots \ldots \ldots \ldots \ldots$. $30 \quad 35 \$ 3 \quad 50$

Cotinus (Purple Fringe). H 8-10, S 8.... 25 250

Cotinus atropurpurea. Inproved Purple

Fringe..................... 50

Glabra laciniata (Cut-lcaved Sumac). H 4

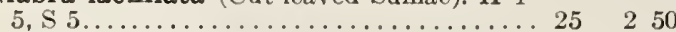

Typhina (Common Sumae). H 10-12, S 6. 20 $20 \quad 150 \$ 1000$

Aromatica (Swcet-scented Sumac). H 4-6,

s $5 \ldots \ldots \ldots \ldots \ldots \ldots \ldots \ldots \ldots, 40$

RIBES aureum (Missouri Currant). H 4-5, S 5. $20 \quad 200 \quad 1300$

Gordonianum. H $4-5$, S $5 \ldots \ldots \ldots \ldots \ldots 20200$

ROBINIA hispida (Rose-flowered Acacia). Extremely free-flowering and attractive.

$\mathrm{H} 4-5, \mathrm{~S} 5 \ldots \ldots \ldots \ldots \ldots \ldots \ldots \ldots \ldots \ldots \ldots 20 \quad 200$

RUBUS odorata (Thimble Berry). Splendid foliage and purplish flowers all summer. $\mathrm{H}$ $4-6,55$

RHODORA Canadensis. Small shrub with very pretty purplish flowers which appear in the spring before the leaves come out very attractive. H 1-2, S $2 \ldots \ldots \ldots \ldots \ldots, 40400$

SAMBUCUS Canadensis (Common Elderberry). Very striking when planted in rich soil. H $6-8 \ldots \ldots \ldots \ldots \ldots \ldots \ldots \ldots \ldots .20$

Canadensis aurea (Golden-leaved Elderberry). . . . . . . . . . . . . . . 25

Laciniata (Cut-leaved Elderberry)........ 25

*Pubens. This rare variety has bright red fruit in the spring, when the common Elderberry is in bloom; very showy.......... 20

SPIRAA Arguta. Pure white flowers early in the spring. H $5-6$, S $5 \ldots \ldots \ldots \ldots \ldots . . .30$

Anthony Waterer. A beautiful dwarf flowering shrub of great popularity. "This is a seedling of that variety of Spircea Japonica which is known in gardens as $S$. Bumalda, and which is distinguished by its dwarf, eompact habit, its persistent flowering, and bright red flowers. Spiraa Anthony Waterer differs from its parent in the deeper, brighter and more intense color of the flowers. As it begins to flower freely when only a few inehes high, and continues to produce its large, flat corymbs from July until frost appears, this shrub promises to be a capital addition to the rather short list of autumn-flowering hardy shrubs." H 2-3, S 3. Two-year-old plants. . 20

Ariæfolia. Tall, graceful variety with white flowers in summer................. 30

Billardi. Pink spikes of flowers in the summer. H 5-6, S 5... ........... 20

Callosa. Pink flowers all summer. H 3-4, S 4. 25

Carpinifolia. Flowers in white panicles. H $6-8, \mathrm{~S} 6 \ldots \ldots \ldots \ldots \ldots \ldots \ldots \ldots 20$

Douglasii. Deep pink spikes of flowers. Fine for massing. H 5-6, S 5, July, August.... 20

Lindleyana. Splendid foliage and flowers; very picturesque but not very hardy; needs a sheltered location and well-drained soil. H $5-6$, S $6 \ldots \ldots \ldots \ldots \ldots \ldots \ldots \ldots \ldots \ldots$

Opulifolia aurea (Ninebark). Vigorousgrowing variety with yellowish foliage; white flowers followed by showy sced-pods. H 810, S $6 \ldots \ldots \ldots \ldots \ldots \ldots \ldots \ldots . \ldots . \ldots 20$

Paniculata rosea. A vigorous grower with pink flowers in July.................20 20

Reevesii fl. pl. Double white flowers in May. H $5-6$, S $5 \ldots \ldots \ldots \ldots \ldots \ldots \ldots 25$

Frobeli (Frobel's Spirea). Free-blooming sort with pink flowers............... 20

Regeliana. Pink flowers in panicles. H 6

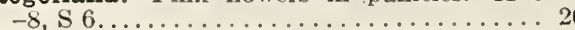

Salicifolia (Willow-leaved Spirea)........ 20

Sorbifolia. A handsome variety with fernlike foliage and showy spikes of white flowers in July. H $3-4, \mathrm{~S} 4 \ldots .$.

$250 \quad 1500$

250
Spiræa Tomentosa. l'ink flowers; hardy Each Per djz. 100 and distinct. $\mathrm{H} 5-6, \mathrm{~S} 5 \ldots \ldots \ldots \ldots \ldots$. $20 \quad \$ 175 \$ 130$

Thunbergii (Snow Garland). The first shrub to flower in the spring; pure white flowers in profusion, Very lovely. H $4-5$, s $4 \ldots \ldots 20200$

Van Houttei. A very graceful variety. One of the best; by many people considered the most satisfaetory shrub in cultivation; white flowers in the grcatest profusion in May. H $6-\gamma, \$ 6 \ldots \ldots \ldots$
MPHORICARPOS. The Symphoricarpos are very desirable in the shade or under trees where nothing else will grow. They are covered with white or red berries in fall and winter.

*Racemosus (Snow-Berry). White-fruited. H $4-5, \mathrm{~S} 5 \ldots \ldots \ldots \ldots \ldots \ldots \ldots \ldots \ldots \ldots 20 \quad 1 \quad 75 \quad 1300$

* Vulgaris (Indian Currant) Red-fruited. H $3-4$, S $4 \ldots \ldots \ldots \ldots \ldots \ldots \ldots \ldots \ldots . . .20 \quad 175 \quad 1300$

*Variegata. Beautiful variegated foliage. II

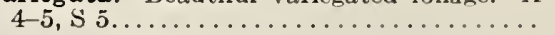

STAPHYLEA Colchica. Extremely sweetscented and frce-flowering shrub; very desirable. H $7-8, \mathrm{~S} 6 \ldots \ldots \ldots \ldots \ldots \ldots 30$

STYRAX Japonica. This rare gem is one of the most desirable shrubs known. When in bloom it is literally covered with creanwhite bells. H $12-15, \mathrm{~S} 10 \ldots \ldots \ldots \ldots .35$

STEPHANANDRA flexuosa. A very graceful shrub, with decply cut fern-like foliage. H $3-5, \mathrm{~S} 4 \ldots \ldots \ldots \ldots \ldots \ldots \ldots \ldots \ldots \ldots 20 \quad 200$

STUARTIA pentagyna. A very rare shrub with exquisitely beautiful, large, single white flowers in July. H $6-8 \ldots \ldots \ldots \ldots \ldots 100 \quad 1000$

TAMARIX. Tall, slender shrubs with feathery foliage and large panieles of lovely pink flowers in late spring or early summer.

Africana. H $8-10$, S $6 \ldots \ldots \ldots \ldots \ldots \ldots 25 \quad 250$

Aestivalis hispida. H 8-10, S $6 \ldots \ldots \ldots .25 \quad 250$

Plumosus (Japanese Tamarix). H 10-12, S 6. $25 \quad 250$

VIBURNOM Lantana. Showy red fruit. H 8-

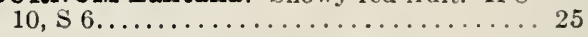

Opulus sterilis (Snowball). H 8-10, S 8... 20

Opulus nana. Very dwarf. H 1-2, S 2 ... 25

Oxycoccus (Cranberry Tree). Very showy red fruit. $\mathrm{H} 8-10, \mathrm{~S} 8 \ldots \ldots \ldots \ldots \ldots . . . .30$

Plicatum (Japan Snowball). One of the choicest shrubs. H $8-10$, S $10 \ldots \ldots \ldots \ldots 35$

Dilatatum. Scaree and choice.........100

Tomentosum. Rare and choice. H 8-10,

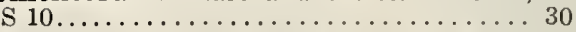

Dentatum. A most beautiful and satisfaetory shrub. H $6-8, \mathrm{~S} 6 \ldots \ldots \ldots \ldots \ldots \ldots 25$

Macrocephalum. A rare variety of great beauty; immense heads of white flowers.

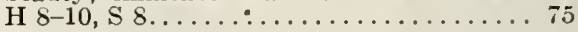

VITEX Agnus-castus (Chaste Shrub). Blue.. 20

White........................ 20

WEIGELA candida. White Decidedly the most desirable of its color. H 6-8, S 8.... 20

Rosea. Pink flowers. H 6-8, S $8 \ldots \ldots \ldots 20$

Rosea nana variegata (Variegated-leaved). H $4-5, \mathrm{~S} 5 \ldots \ldots \ldots \ldots \ldots \ldots \ldots \ldots . . \ldots 20$

Floribunda. Crimson. H 6-8, S $8 \ldots \ldots \ldots 25$

Eva Rathke. Very valuable everblooming variety; large erimson flowers. H 5-6, S 6.25

Conquete. (Novelty.) Enormous flowers,

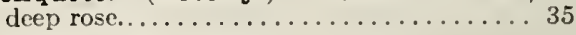

Amabilis. Light pink. H $6-8$, S $8 \ldots \ldots \ldots 20$

Lavallei. Dark, purplish red flowers...... 20

XANTHOCERAS sorbifolia. Rare and beautiful........................ 75

XANTHORRHIZA apiifolia........... 25 


\section{Evergreen Shrubs}

All Evergreen Shrubs should be planted early in September and in the spring

ANDROMEDA floribunda. Very neat Each Per doz. 100 dwarf evergreen shrub, with lily-of-thevalley-like flowers, desirable and rare....\$1 $50 \cdot \$ 16 \quad 00$

Japonica. Evergreen variety from Japan.

very attractive................... $150 \quad 1600$

BERBERIS Neuberti. Holly-shaped leaves; very handsome................ $30 \quad 300$

DAPHNE Cneorum. Exquisite creeping evergreen plant with lovely pink flowers; rare and charming; pot-grown plants.........

ILEX opaca (American Holly)... Crenata. A dwarf Holly of beautiful habit and foliage; perfectly hardy, and covered with black berries in the winter........

* KALMIA latifolia. Known as the Smallleaved Mountain Laurel. One of the most
beautiful flowering shrubs in cultivation. Nice, small nursery-grown plants........

$$
30 \quad 300
$$

$100 \quad 1000$

*LEUCOTHOE Catesbæi. Graceful ever- Each Per doz.

100 green shrub, with white, bell-shaped
flowers......................... $\$ 0 \quad 25 \quad \$ 2 \quad 50$

*MAHONIA aquifolium

$20 \quad 200 \$ 1200$

*RHODODENDRON maximum. Our wellknown Mountain Rhododendron, blooming in July. Nice nursery-grown plants. Larger plants, $\$ 1, \$ 1.50, \$ 2, \$ 3, \$ 4$ and $\$ 5$ each. Plants $\$ 3$ and $\$ 5$ each are splendid specimens.

*Catawbiense. The wild Rhododendron of the southern mountains; very desirable. Fine nursery-grown plants............. $100 \quad 1000$

*Punctatum. A dwarf native Rhododendron with pale pink flowers; very early;
nice; 18 to 24 inches.............. $150 \quad 1500$

\section{Ornamental Deciduous Trees}

With the exception of Birches, Dogwoods, Magnolias, Pin Oaks and Willows, we do not grow trees. The following list of trees is selected from the best nurseries in the United States. Orders will be shipped from the nearest nursery that can supply the stock ordered, so as to save freight charges and secure quickest possible delivery; where stock is ordered in considerable variety, it is sometimes shipped from two or more nurseries to secure trees of the best quality. We always endeavor to secure the best stock in the market for our customers. The prices quoted are for trees of the most suitable size for transplanting; extra-large trees of many varieties can be supplied, but are not recommended. If quick results are desired they can be had by taking small- and medium-sized, but perfectly vigorous and healthy trees, and give them liberal planting; for instance, dig a hole 3 feet deep and 5 feet in diameter for each tree, and fill with all good surface soil, mixed with one-fourth of its bulk of rotted stable manure.

It costs considerable to plant trees in this manner, but the results justify the expense, and people often pay from $\$ 10$ to $\$ 50$ each for larger trees, which always fail, generally dying outright within three years, and never making vigorous, healthy trees. Some kinds of trees may be safely planted much larger than others. Magnolias, Beeches, Tulip Trees and white-leaved Lindens are difficult to transplant, and small-sized trees of these should always be selected. Some varieties should always be planted in the fall, others in the spring, and we shall be glad to advise our customers on these and other points in regard to planting.

Lowest net prices will be quoted for trees by the 100 and 1,000 , on application. Specially desirable trees are marked with asterisk (*). AILANTHUS glandulosa. Female trees, which are Each Per doz.
almost free from disagreeable odor..........\$1 $00 \$ \$ 1100$

ALDER, Cut-leaved..................... 125

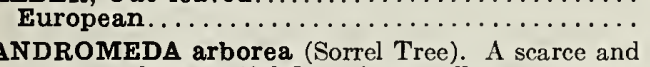
extremely beautiful flowering small tree........

ASH, American White.

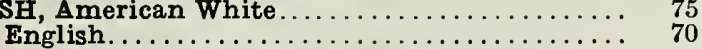

$\begin{array}{lll}25 & 800\end{array}$

50

$50 \quad 500$

$\begin{array}{lll}5 & 8 & 00 \\ 7 & 7 & 00\end{array}$

BALM OF GILEAD. See Poplars.

BEECH, the noblest of trees, but are of slow growth and difficult to transplant. Small trees should always be selected and well pruned when planted.

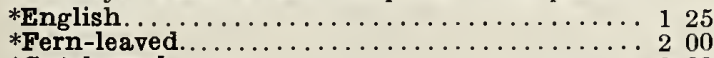

*Cut-leaved................................... 20

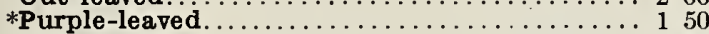

*Weeping. . . . . . . . . . . . . . . . . . 150

*BIRCH, European white................ 50

*Cut-leaved Weeping.................... 100

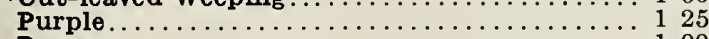

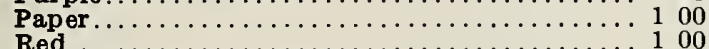

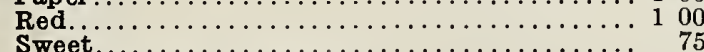

Plant Birches in the spring.

BUTTONWOOD. See Sycamore.

CATALPA Bungei (Indian Bean or Cigar Tree).

Standard $\ldots \ldots \ldots \ldots \ldots \ldots \ldots$
Large specimens, $\$ 3, \$ 5, \$ 7.50$ and $\$ 10$ each. Large specimens, $\$ 3, \$ 5, \$ 7.50$ and $\$ 10$ each.
Umbrella-headed tree used for formal effects.

Bungei. Grafted at the ground............. 100

Speciosa. Our native variety .............. 50

CERCIS Canadensis (American Judas Tree)...... 40

Japonica (Japanese Judas Tree)................ 75

CHERRY, European Bird ............... 80

American wild....................... 60

Double-flowered White...................... 80

Double-flowered Pink........................ 80

Rose-flowered (Weeping Japanese). Unique and 200

CLAdRASTIS tinctoria (Virgilia lutea)......... 125
CRAB APPLE. The ornamental Crab Apples are un- Each Per doz. doubtedly the most beautiful small-flowering trees in cultivation; even more beautiful than the popular Magnolias. They are of the easiest culture, hardy, and bloom when quite small.

*Parkman's (Pyrus Parkmani).

*Bechtel's New Double-flowered......

*Common Wild (Pyrus coronaria) ............. 75

Double White (Pyrus spectabilis).............. 75

Floribunda. Single-flowered, pink; ne of the most

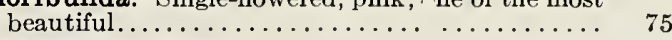

CYPRESS Deciduous.................. 100

*DOGWOOD, White-flowering............. 40

*Red-flowering ....................... $100 \quad 1100$

Weeping.......................... $100 \quad 1100$

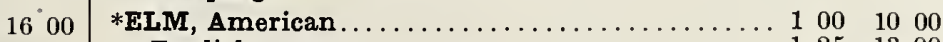

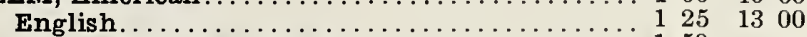

Camperdown Weeping.................. 150

*HONEY LOCUST, American.............. $60 \quad 600$

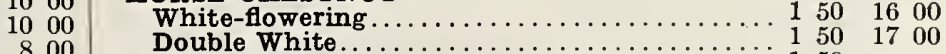

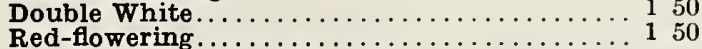

KENTUCKY COFFEE TREE (Gymnocladus Cana-

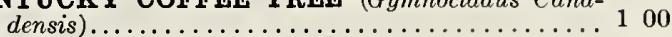

KOELREUTERIA paniculata............ 75

LARCH, European.................. 30

LINDEN, $\operatorname{\Delta merican\ldots \ldots \ldots \ldots \ldots \ldots \ldots \ldots } 125$

*White or Silver-leaved. A superb tree........... 2 200

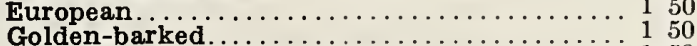

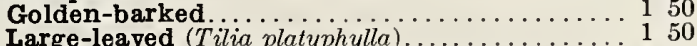

$\begin{array}{ll}8 & 00 \\ 6 & 00\end{array}$ LIQUIDAMBAR styraciflua (Sweet Gum)........ 1000

800 MAGNOLIA acuminata (Cucumber Tree)........ 75

$800 \quad$ Glauca (Sweet Bay)....................... 75

Macrophylla (Giant-flowered Magnolia). Flowers

12 to 15 inches across................... 150

1200

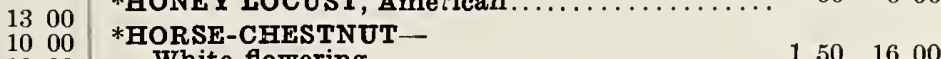

$\begin{array}{rr}\$ 8 & 00 \\ 6 & 00\end{array}$

750

50

\section{0}


ORNAMENTAL DECIDUOUS TREES, continued

Chinese and Japanese Magnolias

MAGNOLIA conspicua. A superb, large-flowered Each Per doz. white In agnolia..................... \$5 00

Purpurea (Obovata). I'urple. $\begin{array}{lll}50 & \$ 5 & 00\end{array}$

* Soulangeana. White, pink center; a splendid sort that is literally covered with large flowers early in the spring. Specimens prepared for trans-

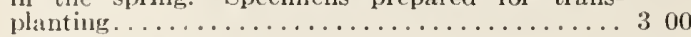

* Stellata (Halleana). A dwarf, white varicty of ex-

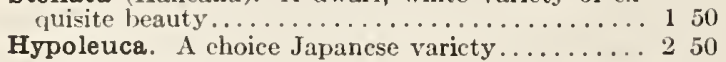

Parviflora (Watsoni). A very scaree and extremely lovely Japanese variety ................ 250

Lennei. A beautiful sort, with large, purple flowers. 400

Kobus. A Japanese white variety........... 75

Gracilis. Purple flowers

Magnolias should be planted in the spring.

MAPLE, Ash-leaved (Box Elder).

European Cork.

Norway.

Purple Norway

Schwedler's Purple

Silver-leaved (Water, or Soft)

Striped Bark (Acer Pennsylvanicum)

Sugar, or Rock.

Sycamore

Wier's Cut-leaved

Red, or Scarlet.

Mountain (Aeer spicatum). Small

Tartarian

MOUNTAIN ASH, European.

MULBERRY, New American

Downing's.

Russian

White

50

Teas' Weeping

NUTS, Almonds. Hard or soft shell .

Chestnut, American

\section{Alpha \\ Perry's Giant ...}

*Japan $\ldots \ldots \ldots \ldots$

*Paragon .......... 150

*Numbo....................... 150

*Hickory (Shellbark) ................... 100

Walnut, Black .

English.

Japanese

40

75

60

OAK. The planting of Oaks for ornament has been done but little on aceount of their supposed slow growth. They grow quite as rapidly as other hardwood trees, and the Pin Oak is of a very rapid growth, and one of the finest trees in cultivation.

*White

150

Turkey

* Scarlet. A grand trec, with splendid coloring in fall. 150

Bur or Mossy Cup.................... 150

OAK, Fin (Qucrcus palustris). One of the very finest trees for avenue or lawn planting, and of very rapid growth. The great demand for this tree has made it very searee. 5 to 6 fect.

6 to 7 feet

10 to 12 feet

10 to 12 feet; specimens

Golden

English

Red

$90 \quad 950$

$\begin{array}{llll}1 & 00 & 10 & 50\end{array}$

$\begin{array}{llll}1 & 50 & 16 & 00\end{array}$

$\begin{array}{llll}1 & 75 & 18 & 00\end{array}$

$200 \quad 2200$

500

200

175

175

*PAULOWNIA imperialis (Empress Tree)...

PEACH, Double-flowering. Pink, white and crimson

PERSIMMON, American.

PHOTINIA villosa. A very ornamental tree covered with red berries in fall and winter...........

$75 \quad 800$

$40 \quad 460$

75

75

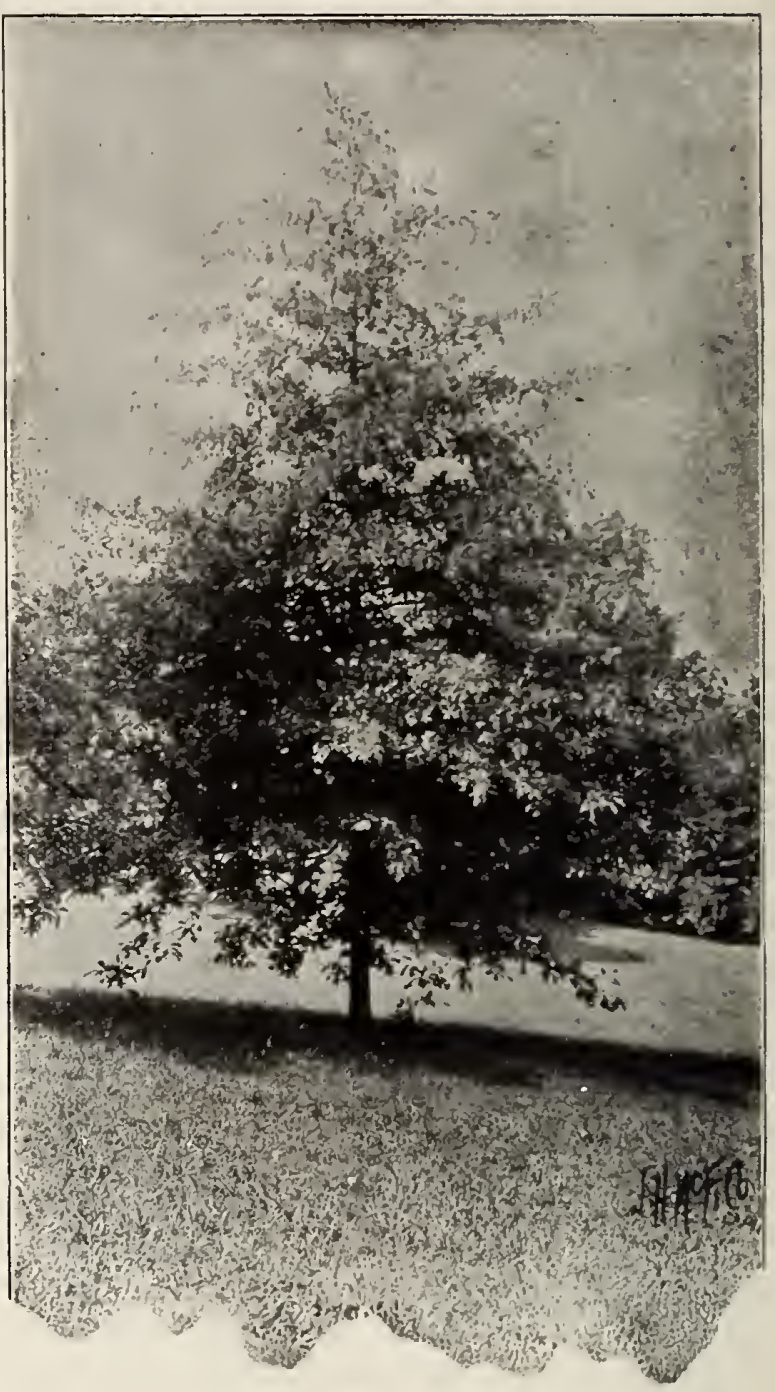

Pin Oak

PLANE. See Sycamore.

Each Per doz.

PLUM, Purple-leaved (Prumus Pissardi).

$\begin{array}{llll}\$ 0 & 35 & \$ 3 & 50\end{array}$

POPLAR, Carolina

Lombardy

Pyramidal ( $P$. Bollcana)

$50 \quad 500$

Golden

$\begin{array}{lll}75 & 8 & 00\end{array}$

$75 \quad 800$

SALISBURIA adiantifolia (Ginkgo, or Maidenhair

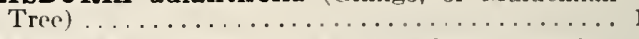

1100

SASSAFRAS. A small native tree; seldon used, but

extremely desirable for its foliage ............ 50

550

SOPEORA Japonica ................ 100

SYCAMORE, Oriental. The Oricntal Sycamore is

extensively used in Europe for strect planting.... $1150 \quad 1700$

THORNS. See Hawthorn, under head of Hardy Shrubs.

TULIP TREE (Liriodendron tulipifera).......... $100 \quad 1100$

WILLOW, Weeping ................... $50 \quad 550$

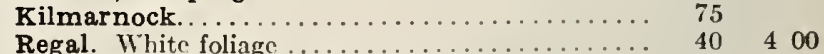

Laurel-leaved. Very handsome.

Salamonii. New Weeping, of remarkably rapid growth.

$30 \quad 300$

Golden-barked $\ldots \ldots \ldots \ldots \ldots \ldots \ldots$

Flame-colored ...................... $20 \quad 200$

YELLOW WOOD. See Cladrastis. 


\section{Evergreens}

The prices quoted are for trees frequently transplanted and of fine shape, suitable for ornamental planting. When it is desired to make extensive plantations, extremely low prices can be made by the 100 or 1,000. Evergreens should be planted in the spring. Many seasons they can be planted safely in September, but the risk of shipping at this timc is great, on account of hot weather.

Rare evergreens, not obtainable in this country, will be imported to order.

\section{ARBORVIT AS-}

American. 15 to 18 inches..... \$15 per $100 \ldots \$ 020 \$ 200$

....... $\$ 30$ per $100 . \$ 35 \$ 200$

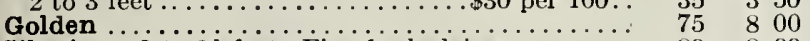

Siberian. 2 to $2 \frac{1}{2}$ feet. Fine for hedging............ 80 8 800

15 to 18 inches. Suitable for hedging

\section{Globosa}

Pyramidalis.

Ellwangerian

Boothii. Extra fine

$\$ 40$ per $100 \ldots$

BIOTA elegantissima

Elegantissima aurea

IR, Balsam.

\section{Cephalonian}

European Silver

Nordmann's. A superb evergreen

Specimens.

JUNIPER, Virginiana glauca

Virginiana (Red Cedar)

Savin.

Prostrate

Irish

PINE, Austrian

Stone (Pinus Cembra)

Mugho

Scotch

White

500

500

1100

500

500

50

200

75

800

500

150

1600

500

125

1200

$\$ 2, \$ 3, \$ 4$, and 500

150

125

75

50

100

200

50
100

RETINOSPORA. The Retinosporas ale all smallgrowing evergreens of exquisite foliage and fine coloring. They can be used on small grounds, as they take up but little room.

Aurea gracilis.

Filifera

500

2200
Retinospora, continued
Filifera a urea........

Leptoclada.

.

obtusa compacta aurea. $i$ to $i \frac{i}{2}$ feet............. 1 o0 1000

Plumosa.................................. $7_{75} r_{8} 00$

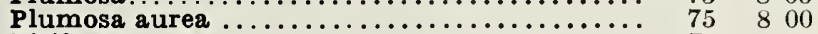

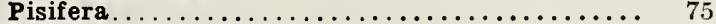

Pisifera aurea......................... $100 \quad 1000$

SPRUCE, Alcock's ..................... $150 \quad 1500$

Douglas'. Magnificent and very hardy ............. $1 \begin{array}{llll}25 & 12 & 00\end{array}$

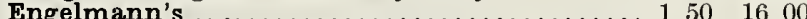

Hemlock. This native evergreen is one of the finest and most graceful trees in cultivation. It makes the most beautiful of all evergreen hedges.

18 to 24 inches.............\$50 per $100 \ldots, 60 \quad 550$ 24 to 36 inches............ $\$ 85$ per $100 \ldots 100 \quad 1100$

Colorado Blue. One of the most beautiful evergreens and one of the hardiest.

18 to 24 inches .................... 350

2 to 3 feet. Selected blue specimens .........4 50

3 to 4 feet. Selected blue specimens ..........6 600 Green form often sent out as the true blue...... 100

Concolor. Very scarce and beautiful. 2 to 3 fcet . $200 \quad 900$

$700 \quad$ Concolor

Weeping Norway. Very curious and picturesque

tree................................ 1 50

Oriental ............................... 100

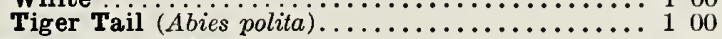

YEW, Irish Golden . . . . . . . . . . . . . . 250

English

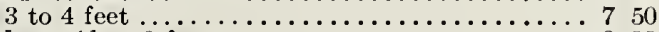

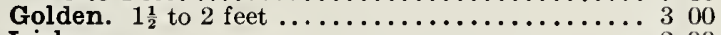

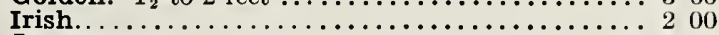

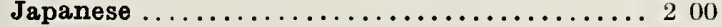

\section{Ornamental Hedges}

Hedges can be used to advantage on all suburban and country places, large or small. Where protection against cattle is not needed, a well-kept hedge is far more beautiful than the most costly wall or fence. At Newport, the most beautiful summer resort in America, hedges are very popular and are used more than either walls or fences. We have made arrangements for supplying all the best varieties of hedge plants at extremely low prices.

\section{Trimmed Hedges}

CRATEGUS Oxyacantha (English Hawthorn). This is the Thorn that is used all over England for field and farm

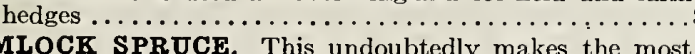

HEMLOCK SPRUCE. This undoubtedly makes the most beautiful evergreen hedge that can be grown in this climate. It is perfectly hardy, a fine rich green in color, which celor it retains all through the winter; and no matter how hard it is trimmed, the peculiar feathery appearance of its young growth always gives it a graceful appearance. Plant 18 to 24 inches apart. 8 to 12 inches. 3000

MAEONIA aquifolium. This, which is one of the most beautiful evergreen shrubs, makes a splendid hedge. It is covered with showy yellow flowers in the spring, but its greatest beauty is its foliage, which is fine at all seasons of the year, but especially so in the fall and winter, when it turns to the finest bronze and crimson. Plant 18 inches apart.

PRIVET, Regel's. The very best privet for hedging or any other purpose; beautiful habit and foliage and perfectly hardy.

12 to 18 inches.....

$2 \frac{1}{2}$ to 3 feet

Amoor River. (True.) Upright-growing like California but perfectly hardy. This variety must not be confused with so-called Amoor River Privet, sold in the South, which is really Ligustrum Chinense, and not hardy in the North

California. Immensely popular for hedging, but very inferior to Regel's Privet, and not reliably hardy here and farther north.

1 year old.

2 years old

3 years old $\ldots \ldots \ldots \ldots \ldots \ldots \ldots \ldots \ldots \ldots \ldots \ldots \ldots \ldots \ldots \ldots \ldots \ldots \ldots \ldots$
Common. Makes a good hedge and will stand in extreme northern states, where California Privet is not hardy....

\section{Untrimmed Hedges}

Untrimmed hedges are allowed to grow naturally without pruning, and, as a rule, are not suitable for planting on the boundaries of grounds, but can be used for inclosing flower- or vegetable-gardens, on the edges of terraces and along roads and walks. Sometimes they can be used to conceal unsightly but necessary fences.

ALTH必A (Rose of Sharon). These make a desirable flower-Per 100 ing hedge; bloom in August. They should be cut back to keep them compact. Extra-strong plants, seedlings.

$\$ 800$

Best Named Varieties. Strong plants ............... 1400

BERBERIS Thunbergii (Japanese Barberry). One of the most beautiful shrubs in cultivation, either for hedging or general purposes. It is of a neat, compact growth and never need be touched with the shears. The foliage is beautiful at all times, and in the fall turns to a most brilliant erimson color, but its most attractive feature is its fruit. The plant is literally covered with bright scarlet berries all the fall and winter. Plant 15 to 18 inches apart. Large plants.

CORCHORUS Japonicus variegatus. This makes one of the daintiest little hedges imaginable. The growth is slender and graceful, the foliage is of fine form and variegated, and after the leaves drop in the fall the twigs are a bright green color, which makes it attractive all winter. 1400

LILACS. The common Purple and White Lilacs make a desirable flowering hedge, but, of course, a very tall one. We can supply both colors, nice plants, 1 to 2 feet high.

ROSE, Crimson Rambler. This remarkable fine climbing Rose makes a superb hedge if planted in a row, and cut back early every spring to about 3 feet high ...

Sweetbrier. The popular Sweetbrier makes an attractive hedge and is desirable for planting along a fence......

Mad. Plantier. This hardy white Rose makes a fine hedge and when in bloom nothing can be more attractive ....20 00 


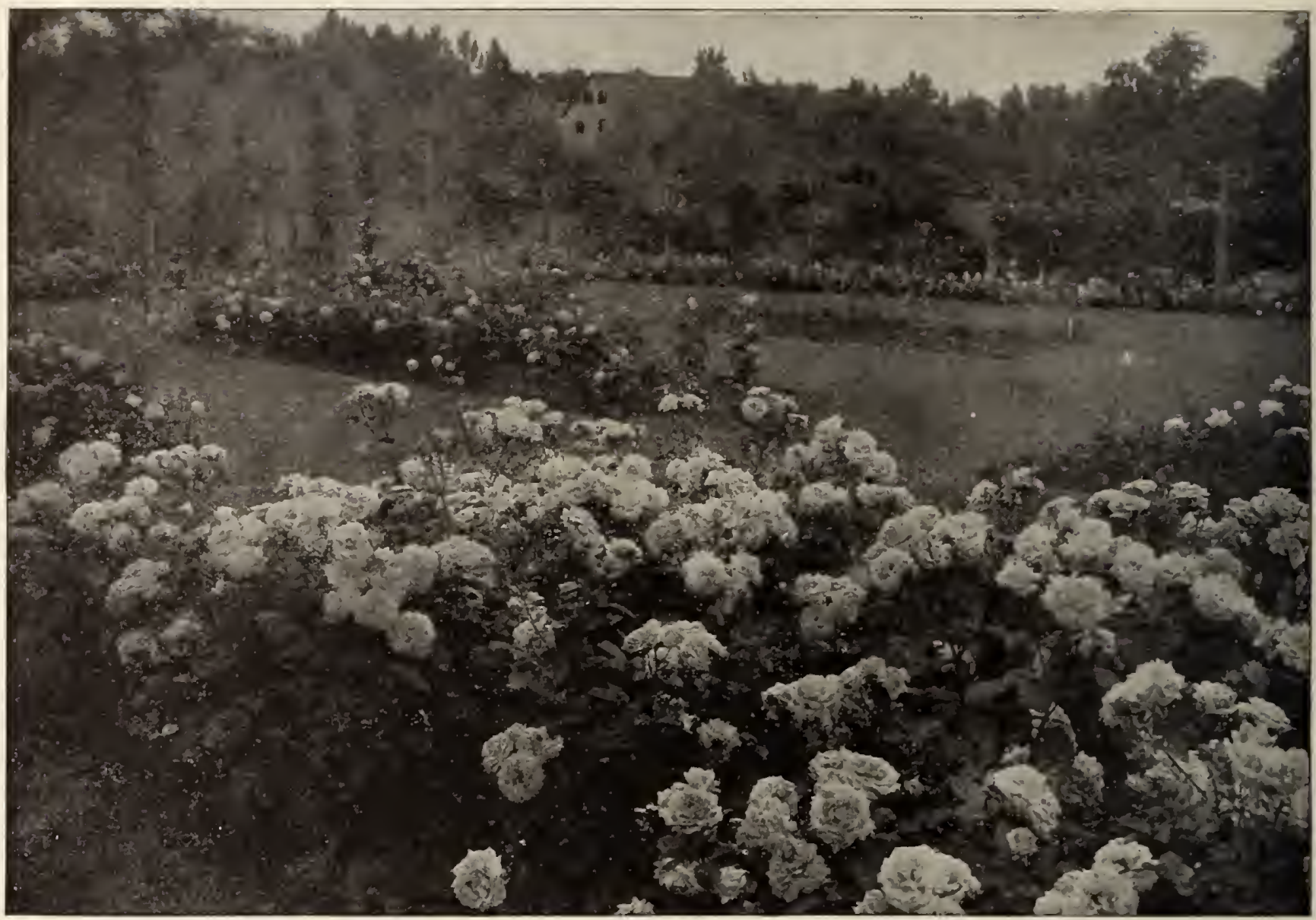

\section{Roses for Spring Planting}

Dormant Hardy Roses can be supplied from October 20 to April 1. Tea Roses all the year.

The dormant Roses should be planted early in the spring-not later than April 10. Tea Roses can be planted any time during the year when the ground is suitable. In planting dormant Roses in the spring it is important that they should be planted as early as possible, and two-thirds of their tops cut off before planting. All our Roses are American-grown, and of the best quality obtainable. Hybrid Perpetuals and Moss Roses are principally low-budded plants; all other kinds are grown on their own roots.

Our collection of Wild Roses and old garden varieties is the most complete in America and contains many varieties not obtainable elsewhere.

We must emphasize the importanee of eutting back dormant Roses when planting. More Roses die in transplanting for lack of this precaution than for any other reason. In planting dormant Roses in our nuirsery we eut them back to within 3 inches of the ground, and, although this is never done until late in May, we rarely lose a plant.

If Roses are received in a dried condition, it is a good plan to soak them in water for twenty-four hours before planting.

\section{Hybrid Perpetuals}

Anna de Diesbach, Baronne de Bonstettin, Coquette des Alpes, Coquette des Blanches, Earl of Dufferin, General Jacqueminot, Jules Margottin, Madame Plantier, Mme. Gabriel Luizet, Magna Charta, Frau Karl Druschki, Prince Camille de Rohan, Clio, Margaret Dickson, AIrs. R. G. S. Crawford, Alfred Colomb, Baroness Rothschild, Marchioness of Lorne, Mrs. John Laing (one of the best; very freeflowering), Utrich Brunner, Marshall P. Wilder, Johii Hopper, American Beauty, Marchioness of Dufferin, Nova Zembla.

Dormant, two-year-old plants for early spring delivery, 35 cts. each, $\$ 3.50$ per doz., $\$ 25$ per 100 . Two-year-old plants in pots, for late delivery, 50 cts. each, $\$ 5$ per doz.

\section{Miscellaneous Roses}

Everblooming. A fine stoek in 4-inch pots-Crimson Baby Rambler, White Baby Rambler, Clothilde Soupert, Gruss an Teplitz, Helen Gould, Kaiserin Augusta Victoria, Killarney, White Killarney, La
France, Maman Cochet (pink), Maman Cochet Per doz. 100 (white), Mrs. Aaron Ward, Mrs. Miarie Guillot, Mme. Caroline Testout, Rhea Reid, Richmond, Souv. du President Caruot .

$\$ 300 \$ 1800$

Moss.-Salet, Glory of Mosses, Perpetual, Whitecrested, Mme. Blanche Morcau, Paul Fontaine, budded

Hardy Yellow.-Persian and Harrison's Yellow ..... 350

Rugosa.-Rugosa rubra and alba, Mne. Geo. Bruant.. 300

Brier.-Rosa mubiginosa (Genuine Scotch Sweetbrier). 200

Climbing Roses.-Queen of Prairie, Baltimore Belle, Seven Sisters, Tennessee Belle, Russell's Cottage... 250

Marechal Niel. Strong plants........50 cts. each.. 500 Tree Roses. (Not reconmuended.) ….............. 1200 New Rugosa Rose, Blanc Double de Coubert. This is a new seni-double Rugosa Rose, with all the good qualities of the species and the most exquisite semi-double white flowers we have ever seen. $35 \mathrm{c}$. ea.. 350 and full; one of the best of the new Rugosas. $35 \mathrm{c}$. ea.. 350 


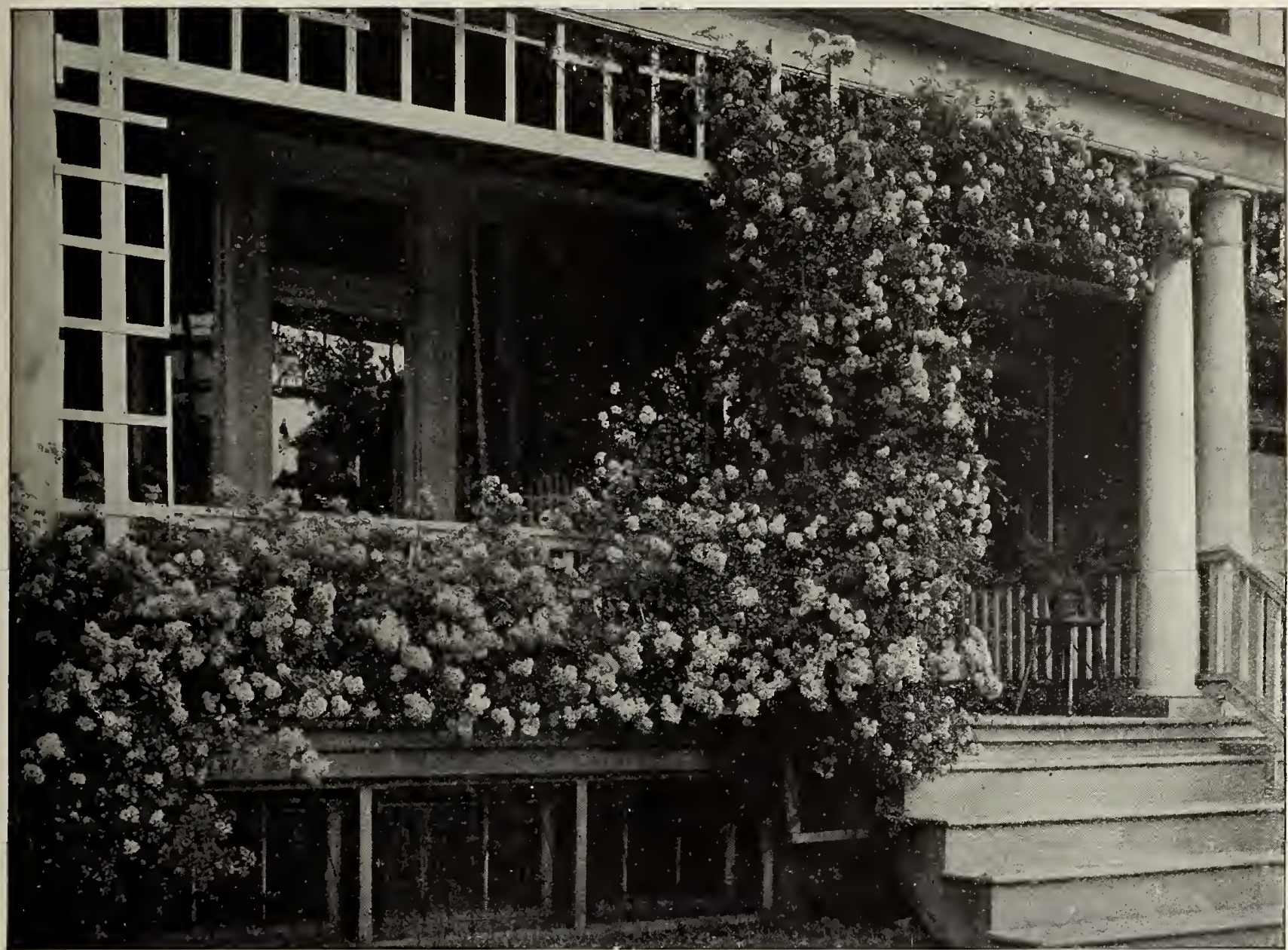

Climbing Rose, Lady Gay

\section{Climbing American Beauty Rose}

A new Rose of great merit. A cross between American Beauty and an unnamed seedling; color a rosy crimson, similar to its popular parent, and with the same exquisite fragrance, a quality rarely found in climbing Roses. The plant is of strong habit of growth, making shoots from 10 to 15 feet in one season, and as hardy as an oak. The flowers are from 3 to 4 inches in diameter, of fine form, and are produced in great profusion, not only in May and June, but there is a fair sprinkling of flowers throughout the growing season. We offer strong, 5-inch pot-plants, 75 cts. each.

\section{Single Climbing Rose, Carmine Pillar}

Immense, single, scarlet flowers; very striking and beautiful. One of the best for porch use, or for covering unsightly features on the grounds. An old Rose, but rare and desirable. $50 \mathrm{cts}$. each, $\$ 5$ per doz.

\section{New Rambler Rose, Tausendschon}

This is an entirely distinct break, not only in ramblers, but in climbing Roses generally. The individual flowers are very large for this type of Rose, being fully 3 inches across, and of a most elegant and graceful form, not stiff or unnatural, but as beautiful as a semidouble azalea. In color it is a most delightful shade of soft pink when first opening, changing to carmine on the reverse of petals when fully expanded. These are produced in trusses of from ten to fifteen flowers. 2-year-old plants, $50 \mathrm{cts}$.

\section{Climbing Rose, Lady Gay}

A new rambler variety of remarkably vigorous growth, with flowers of a delicate cerise-pink, passing to soft, tinted white. The effect of a plant in full bloom with the combination of the soft white flowers, cherry-pink buds, and the deep green of the foliage is indeed charming. Strong, two-year-old plants, 40 cts. each, $\$ 4$ per doz.

\section{American Pillar}

A new single-flowering variety of great beauty, which appeals to every one. The flowers are of enormous size, 3 to 4 inches across, of a lovely shade of pink, with a cluster of yellow stamens. These flowers are borne in immense clusters, and a large plant in full bloom is a sight not easily forgotten. They last in perfection a long time, and are followed by brilliant red hips or berries, which are carried late into the winter; and as the plant frequently retains its lovely green foliage until the end of November, it forms a beautiful decorative subject throughout the autumn months. Strong, two-year-old plants, 75 cts. each, $\$ 7.50$ per doz. 


\section{Rambler Roses}

CRIMSON. It is strikingly beautiful, absolutely hardy, and no Rose ean be used for more purposes. As a climber it is unsurpassed, perhaps, unequaled, as a pot-plant for forcing, the florists are finding it extremely popular. By keeping it cut down it makes a splendid bedding Rose, and a hedge of it is a most beautiful object. $30 \mathrm{cts}$. ach, \$3 per doz, $\$ 20$ per 100; a few extra-strong plants 50 ets. each.

fended. The same habit and color as Crimson Rambler, but a perpetual bloomer. $50 \mathrm{cts}$, each., $\$ 5$ per doz.

DOROTHY PERKINS. This is a splendid new shell-pink climbing Rose. It attracted much attention at the Panl-Ameriean Exposition, where a bed of fourtecn-months-old plants produced a show of bloom unequaled by any other variety. This new Rose is of the are borne in clusters of 30 to 40 , and sometimes even 50 to 60 . The flowers are large for a Rose of this class, very double, sweet-scented and of a beautiful shell-pink. Raised from sced of Rosa Wichuraiana and crossed with that grand old Rose, Mme. Gabricl Luizet. Absolutely hardy. The individual flower is larger than the Crimson Rambler, and is a beautiful shell-pink in color. $30 \mathrm{cts}$. each, $\$ 3$ per doz., $\$ 20$ per 100 .

LEUCHSTERN. Introducer's description: "We received an award of merit for this beautiful variety at the Temple Flower Show in 1901, where our plants caused quite a sensation. The flowers are single in large corymbs, bright rose with a distinct white eye; exceedingly pretty and attractive. Foliage and habit resembling Crimson Rambler, excepting that it is not quite so vigorous; it is well suited for elimbing moderate distances, and for forming large bushes, pillars and pyramids in the garden." 30 ets. each, $\$ 3$ per doz.

HIAWATHA. Distinctly different from other Ramblers. Its small, single flowers-deep ruby-crimson, wonderfully bright-aecen-

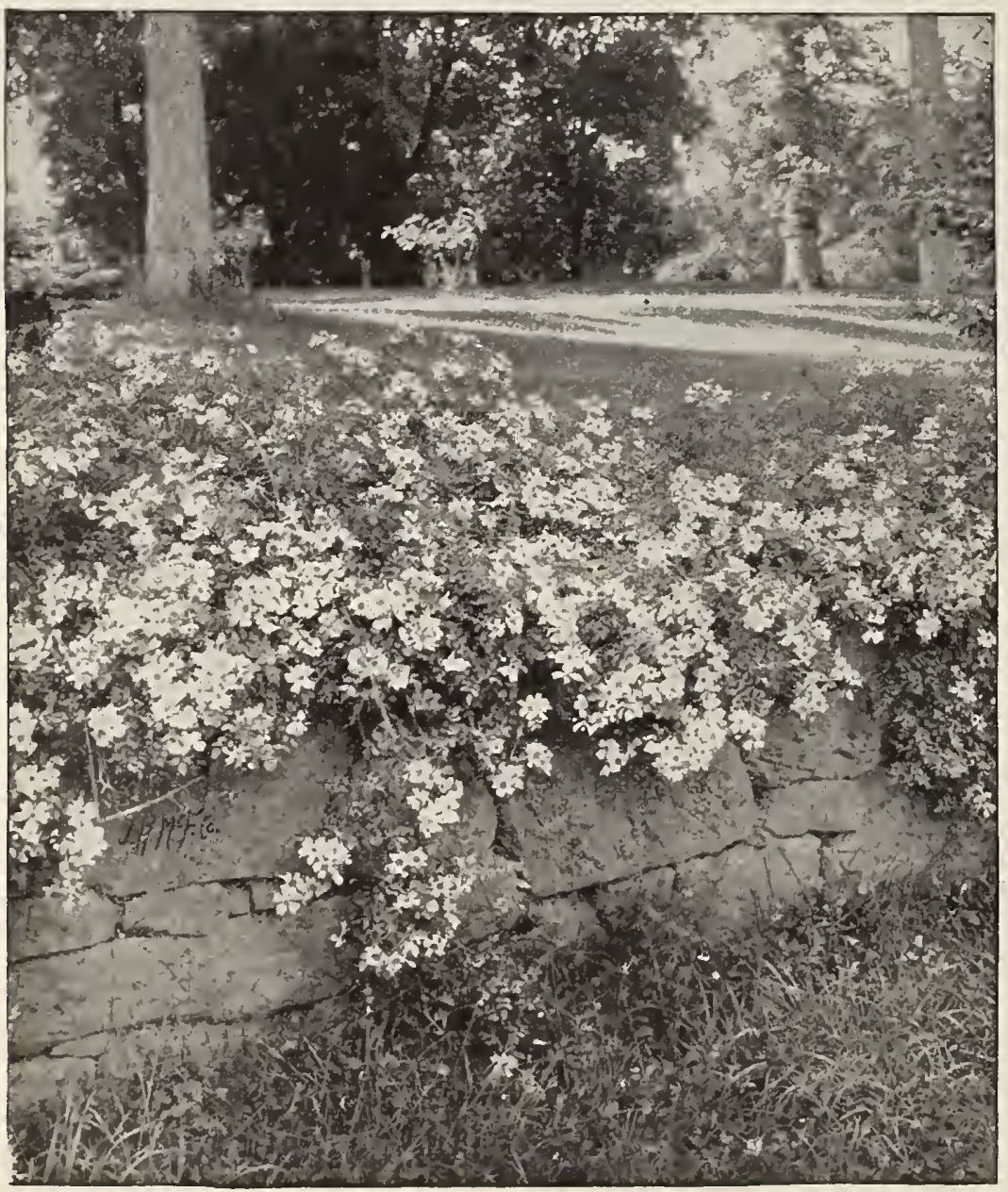

Rosa Wichuraiana covering a stone wall tuated by a white eye-are uniquely borne in long trails of 40 to 50 . This is a charming variety destined to become very jopular anong Rose-lovers. Lovers of single Roses will be delighted with it. In our opinion this Rose is the best and most attractive of all the recent Michuraiona and Rambler hybrids, which have been so frecly offered. $30 \mathrm{cts}$. each, $\$ 3$ per doz.

WHITE DOROTHY. Among Rambler Roses, none has justly gained greater popularity than the beautiful pink Dorothy Perkins. The White Dorothy is a duplicate, in all respects save in color, which is clear, glistening white. A decided acquisition to this class of Roses. Among the multitude of new Roses offered this is one of the few worth planting. Strong two-year-old plants, 40 ets. each, $\$ 4$ per doz.

STANDARD CRIMSON RAMBLER. This Rose, on account of its free-flowering qualities and vigorous growth, makes a beautiful obect when grown as a standard. Fine, strong plants, $6 \mathrm{ft}$. high, $\$ 1 \mathrm{~cd}$.

VEILCHENBLAD. "The Blue Rose." Is it blue? Perhaps, but an unlovely bluc that we do not like. $25 \mathrm{cts}$. each, $\$ 2.50$ per doz.

\section{Rosa Wichuraiana}

In some respects this Rose, which is also known as the "MIcmorial Rose," is better than Crimson Rambler, although it lacks the brilliant color of its more advertised contemporary. As a climber for covering porches, trellises and arches, and as a creeper for covering steep banks or any ground needing covering, it is unequaled. The foliage is a lustrous, shining green. In bloom the plant is literally covered with exquisitcly beautiful single white flowers, which are followed by an abundant crop of bright red hips or berries, which remain on the plant all winter. The Rose is entircly frce from attacks of insects or disease, and is absolutely hardy, root and branch. Strong, 2year-old plants, 30 cts, each, $\$ 3$ per doz., $\$ 20$ per 100 ; strong, 1-year-old plants, 20 cts. cach, $\$ 1.75$ per doz., sio per 100.

\section{ROSA WICHURAIANA HYERIDS}

UNIVERSAL FAVORITE. A frce grower, producing long-branching shoots, with shining foliage in abundance, and soft, light pink, double flowers 2 inches in diametc1; strongly perfumed. $30 \mathrm{cts}$. each, \$3 per doz.

SOUTH ORANGE PERFECTION. This is a gem, with frce growth close to the ground, and produees multitudes of the most perfectly formed, double, white flowers, about $1 \frac{1}{2}$ inches in diameter; soft blush-pink at the tips, changing to white. $30 \mathrm{c}$. each, \$3 per doz.

MANDA'S TRIOMPH. This is a grand hybrid of free growth, with fine foliage and clusters of from twelve to eighteen flowers on even a small-sized shoot, literally covering the plant with its perfectly formed, double, white, imbricated flowers, nearly 2 inches across; valuable for cut-flowers or potplants. 30 cts. each, $\$ 3$ per doz.

PINK ROAMER. This is a hybrid of the Swectbrier, and carries its characteristics in bloom, while the growth which is very rampant, partakes more of the Wichuraiana. The single flowers, which are produced in close heads, are ncarly 2 inches in diameter, bright rich pink, with almost a white center which lightens up the orange-red stamens, producing a fine effect. $30 \mathrm{cts}$. cach, $\$ 3$ per doz.

WICHURAIANA RUBRA. Long, green branches; leaves medium size, glossy green; large clusters of single flowers. $1 \frac{1}{2}$ to 2 inches in diameter bright scarlet petals tinted orange-red, white at the base; numerous orange-red stamens; flowers in June; very distinct and beautiful and valuable for covering fences, pergolas, etc. $R$. Wichuraiana $\times$ Crimson Rambler. 40 cts. each, $\$ 4$ per doz.

JERSEY BEAUTY. R. Wichuraiana $\times$ Perle les Jardins, Extremely vigorous grower, foliage shiny, thick, of leathery substance. Flowers singly or in clusters of two to four; large, single, 3 inches in diameter, opening pale yellow. 30 cts. each, $\$ 3$ per doz.

WEDDING BELLS. Free, vigorous grower, with beautiful foliage and immense clusters of bright pink flowers. Little known but charming; one of the best of the Wichuraiana hybrids. $25 \mathrm{cts}$. each, $\$ 2.50$ per doz. 


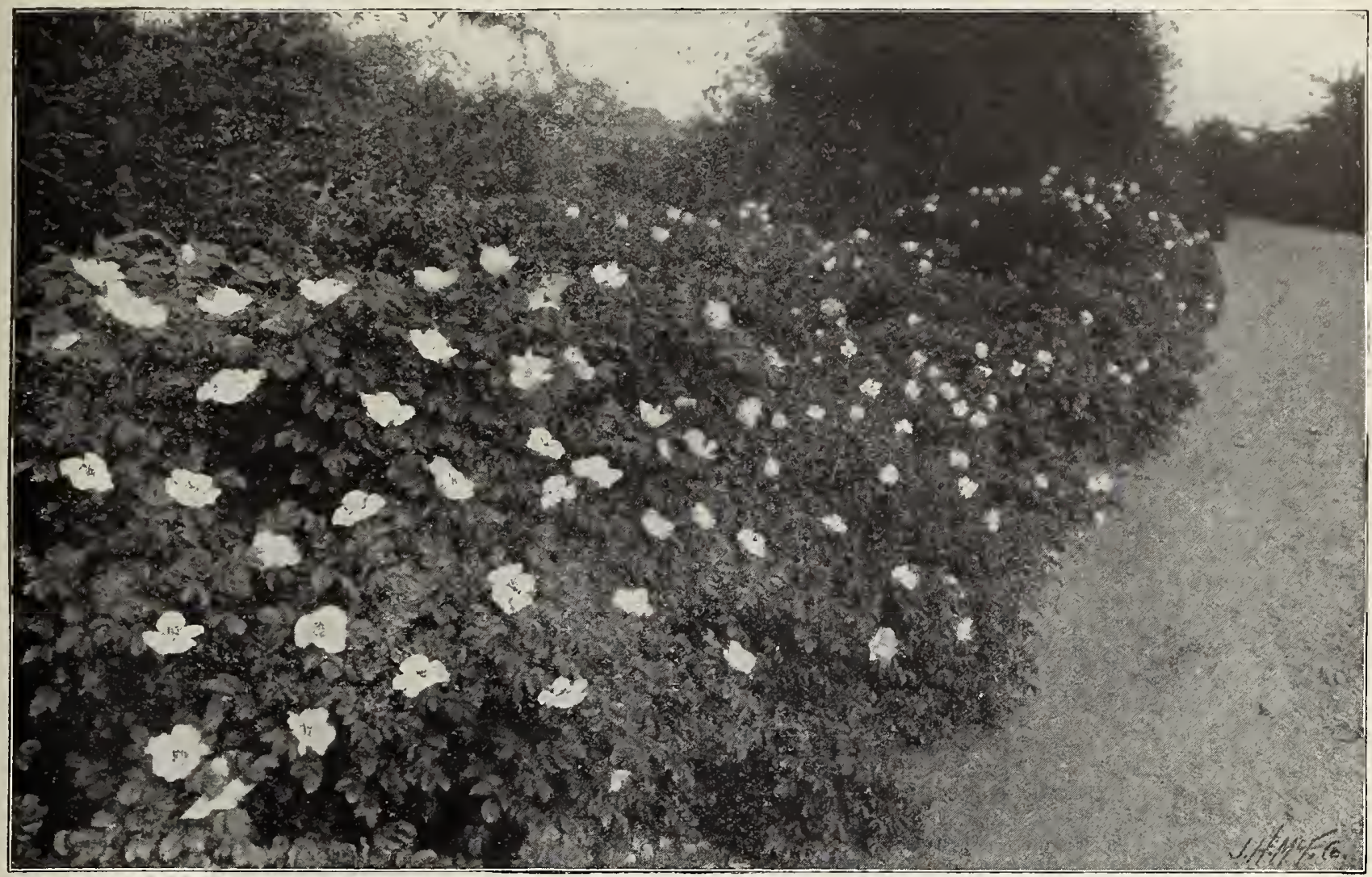

Hedge of Rugosa Roses

\section{Wild Roses of Various Countries}

With the exception of the Japanese Rose, Rosa rugosa, American nurserymen have ignored the numerous wild Roses, - which is unfortunate, for they are undoubtedly the most decorative Roses that can be planted, and splendid effects are to be had with them not obtainable with any other plants; and as a rule they are of the easiest culture, vigorous growcrs, and entirely free from attacks of insects or disease. The flowers of all are, of course, single, but many people, of whom I am one, think single flowers more beautiful than double ones, which after all are abnormal, and the coloring, form and often the arrangement of single Roses is exquisitely beautiful. I think one of the most beautiful garden pictures I have ever seen was a trellis covered with Rosa multiflora with a bordcr of colored peonies at the base of the trellis. Both peonies and Roses were in bloom. The Rose was literally covered with thousands of its lovely white blooms, each with a center of rich yellow stamens.

These wild Roses can be used in many ways. Some are climbers and can be used for covering anything desirable to cover with a climber; others, like Rosa Wichuraiana, are creepers, and are splendid for covering rough banks; and others are desirable for planting among shrubbery, but especially Rosa rubrifolia, Rosa rugosa and Rosa setigera. Rosa rugosa is now pretty well known, but is deserving of the greatest popularity. It has every good quality, splendid foliage, immense single red or white flowers, which bloom freely all the season and which are followed by large, beautiful red fruit, which lasts until severe freezing weather comcs in winter. It should always be planted in masses cither by itself or in connection with other shrubbery. It also makes a beautiful hedge.

ROSA Carolina (American Wild Rose). Each Per doz. 100

Blooms in July.........

Lucida (Dwarf American Wild Rose)...... $25 \quad 2 \quad 50$

Multiflora (Japanese). An extremely beautiful Rose that can be used as a climber... $30 \quad 300$

Pomifera (The Apple Rose). Very vigorous single pink; flowers in June followed by large showy fruit, the largest produced by any Rose. 35

Rubrifolia. Beautiful reddish foliage contrasting well with its beautiful pink flowers; very striking and pretty in groups or planted among shrubbery $\ldots \ldots \ldots \ldots \ldots \ldots \ldots, 30$

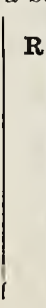

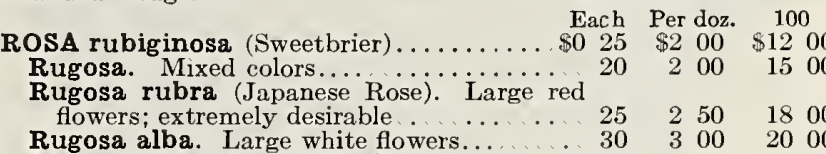

Setigera (Single Prairie Rose). Blooms in July, 25 250

wichuraiana (Trailing Japanese Rose). Splendid for covering banks or trained as a

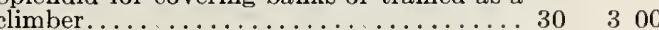

Nuttalliana ....................... $25 \quad 250$

\section{Lord Penzance's Hybrid Sweetbriers}

The Sweetbrier, or Eglantine, is acknowledged by all to possess one of the sweetest perfumes that nature has provided, and its delicious scent is the object for which it is usually cultivated. These new varieties are great improvements upon the old sorts. They are hybrids obtained between the common Sweetbrier and various old-fashioned garden Roses, and are possessed of the following advantages:

The flowers, which are borne in wondrous profusion, are varied in color from white, through several shades of pink, to very dark red or crimson. For vigor of growth there is scarcely anything in the Rose world equal to them. Plants three years old have now many shoots on them that rise to the height of 12 feet. 35 cts. each, $\$ 3.50$ per doz. 


\section{Dahlias}

The following varieties of Dahlias are a seleetion made from the stoek of the most famous Dahlia speeialist in the world, and arc unquestionably the best varieties introdueed to date. The priees quoted are for good strong roots. In .Iay we ean supply pot-grown plants from euttings at a diseount of 25 per eent from these prices.

\section{Newer Dahlias}

20TH CENTURY. Also known as the orchid-flowered single Dahlia. lntense rosy erimson with white tips, and white disc around the vellow eenter. As the season advanees, the dark-eolored zone becomes lighter; flowers 4 to 6 inehes in diameter, exquisitely beautiful. 20 ets. eaeh, $\$ 2$ per doz.

PINK DANDY. A pure pink double show Dahlia, of large size and form. Plant strong and vigorous. 25 ets. eaeh, $\$ 2.50$ per doz.

ELOISE. A eharming double variety and very distinet. The ground eolor is blush-pink shading to white. Eaeh petal is margined with deep glowing erimson. 20 ets. eaeh, $\$ 2$ per doz.

OLYMPIA (Double). One of the grandest faney Dahlias to date. The flowers are of immense size, rose-pink, striped and peneiled with rieh erimson. 25 ets. eaeh, $\$ 2.50$ per doz.

EUREKA (Double). One of the most valuable Dahlias yet produeed, both as a blooming plant and for eut-flowers. The flowers are large to very large, of deep rose-color and fine regular form; quilled petals and perfectly full to eenter. 20 ets. eaeh, $\$ 2$ per doz.

FRANK L. BASSET (Double). Bright royal purple, shading to blue. The nearest approaeh to a blue Dahlia yet produeed. Very free bloomer and fine for eutting. One of the best deeorative Dahlias yet produeed. 20 ets. eaeh, $\$ 2$ per doz.

BRIDESMAID (Caetus). Pale primrose, shading to delieate rose toward the outer petals; beautiful form and free. 20 ets. eaeh, $\$ 2$ per doz.

CAPSTAN (Caetus). Soft, briek-red, shaded apricot. Remarkable for its free and early flowering. 15 ets. eaeh, $\$ 1.50$ per doz.

KONIGEN WILHELMINA (Caetus). Deep erimson, riehly shaded; fine form; a free and eontinuous bloomer. 20 ets. eaeh, $\$ 2$ per doz.

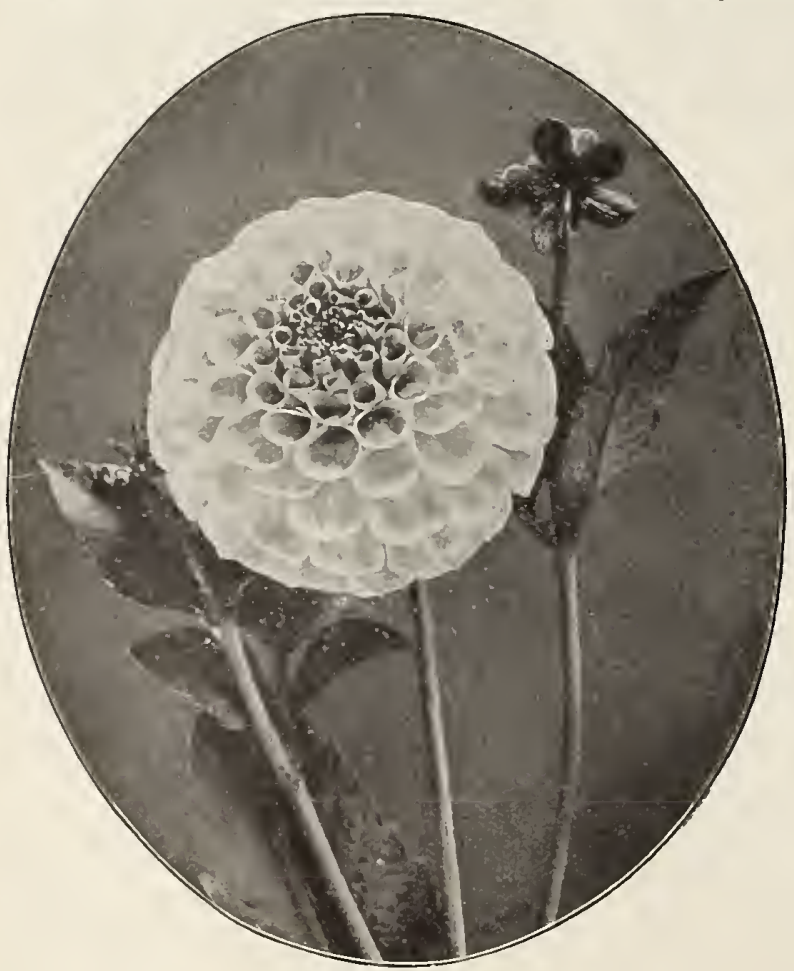

Double Show Dahlia

\section{Cactus Dahlias}

20 cts. each, $\$ 2$ per doz.

Bertha Mauley. Searlet, overlaid erimson-purple.

Blanch Keith. Beautiful pure yellow of largest size.

Cycle. Bright rosy erimson; early and profuse.
Cactus Dahlias, continucd

Geo. Marlow. Primrose-yellow, shaded amber.

Henry Stredwick. Rieh velvety maroon; petals long and narrow. An exquisite flower.

Miss A. Nightingale. Large, deep yellow, heavily tipped bright red; fine eombination; semi-double.

Purity. Pure white, medium size; splendid form; very fine.

Miss Grace Cook. Deep rose-eolor; with pearly white tips.

Kriemhilde. The finest of all pink Caetus Dahlias.

\section{Decorative Dahlias (Double) \\ 20 cts. each, $\$ 2$ per doz.}

Admiral Dewey. Brilliant imperial purple. Of fine form; a strong grower, and hy far the hest of its elass.

Clifford W. Bruton. The best yellow; of immense size, perfeet form, and one of the finest of its eolor. A tall, vigorous grower and extremely free hloomer. Should be in every eolleetion.

Maid of Kent. Cherry-red, tipped white; sometimes a solid eolor, when it is superb red.

Mrs. Geo. Reed. Pure white, beautifully edged and flaked soft rosy lake; the petals overlap each other, and are deeply eleft.

Nymphæa. By far the most delieately beautiful Dahlia ever introdueed; extensively grown for eut-flowers. The flowers are of medium to large size, always full to the eenter, resembling the ideal pink water-lily. The enlor is a elear, distinet, light shrimp pink, tinted lighter toward the eenter.

Zulu. Rightly named "the Blaek Dahlia." Jet-blaek, ehanging to blaek-maroon as the flowers fully expand. Of fine form and full to the eenter.

\section{Show Dahlias (Double) \\ 20 cts. each, $\$ 2$ per doz.}

A. D. Livoni. Beautiful soft pink, with quilled petals and full to the eenter; an early and profuse bloomer.

Arabella. Very fine form; pale primrose, tipped and shaded old-rose and lavender.

Armorer. Deep red dwarf and a profuse hloomer.

Emily Edwards. White, suffused pink; heautiful.

Glowing Coal. Bright glowing erimson.

Hero. Deep erimson-maroon; large, full to the eenter and profuse bloomer.

Mrs. Dexter. Large; a rieh shade of salmon; hest of its eolor.

Psyche. Pale primrose, shaded rose; a dwarf hranehing plant, and one of the most profuse bloomers.

Paul's Scarlet. Brightest searlet.

Queen Victoria. Deep yellow; finely quilled.

Snow. Snow-white; profuse hloomer.

Sport. A pure lavender sport of Penelope.

\section{Fancy Dahlias (Double) \\ 20 ets. each, $\$ 2$ per doz.}

Elegans. Rosy purple, tipped and banded white; quilled petals.

Fern-leaved Beauty. Beautiful fern-leaved sort; white, striped deep erimson.

Keystone. Pink, striped erimson; large, fine.

Leiberheimer. Crimson, striped white.

\section{Single Dahlias}

A colleetion of the best named varieties. 15 ets. eaeh, $\$ 1.50$ per doz

\section{Mixed Dahlias}

The following Dahlias are all seedlings of our own growing. They have all bloomed and produeed just as fine flowers as named varieties.

Single.......................... Per doz. $\$ 100$ 


\section{INDEX}

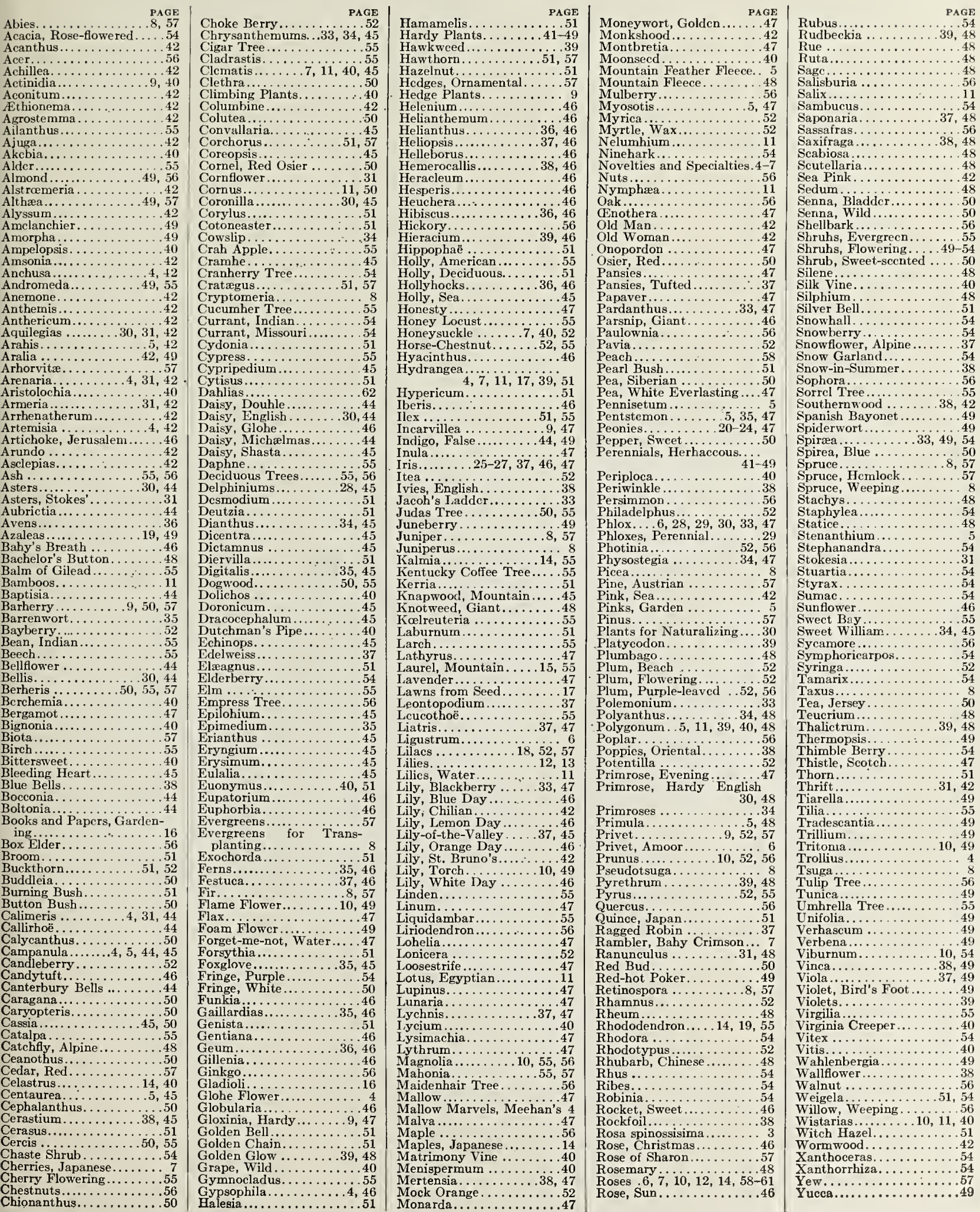




\section{A PLEA FOR HARDY PLANTS}

\section{By J. WILKINSON ELLIOTT}

T TENDER plants predominate in so many modern gardens that lovers of flowers should be 1 grateful to Mr. J. Wilkinson Elliott for bringing forth an argument, in the shape of a sensible and practical book, in favor of our native asters, lilies, hollyhocks and other hardy plants. This book is sure to appeal to all garden makers.

\section{PRESS COMMENTS}

"Certainly one of the most sensible as well as beautifully illustrated nature books that the season has to offer."-Chicago Record-Herald.

"Such a book is an inspiration to the inert land-owner, and has real help to offer the energetic one."-Farm, Field and Fireside.
"An irresistible combination of sensible suggestions and splendid illustrutions." - Los Angeles Herald.

"The price is incredibly small considering the mechanical perfection of the book." - Vasheille American.

"Slould be in the hands of every owner of a country place." - The Argonaut.

PRACTICAL AND WELL ILLUSTRATED NEW AND ENLARGED EDITION. PRICE, NET, \$1.60

DOUBLEDAY, PAGE \& CO., Publishers, Garden City, N. Y.

口

\section{SPECIAL OFFER}

We should like very much to have every one of our customers receive a copy of the book advertised above, and with this end in view we have made arrangements with the publishers by which we can supply our customers with it at a nominal price. With orders for trees, shrubs, plants or bulbs amounting to two dollars or more, a copy of the book bound in cloth may be added for seventy-five cents, but only one copy can be ordered at this price, or every one who sends to us a subscription to that splendidly illustrated magazine, "Country Life in America," will receive a copy of the book, "A Plea for Hardy Plants," free of cost ; or, in other words, the magazine and the book will be sent for the price of the magazine alone, which is four dollars per year.

П result is almost always unsatisfactory, although often the expenditure would have secured most beautiful results if directed by skilled advice. I do landscape gardening-do it for people of exacting taste, to whom I refer. I make the plans, with estimates, purchase the stock necessary and superintend the work. I do any one or all these things, satisfactorily as to results, moderately as to cost. For small grounds I can make satisfactory plans if furnished with a plat drawn to scale. For large grounds, and where extensive improvements are desired, a personal visit would be necessary and can be arranged for on reasonable terms. I can make no plans during the month of April.

\section{J. WILKINSON ELLIOTT}

\section{LANDSCAPE ARCHITECT}

